\title{
Extending Full-Plate Tectonic Models into Deep Time: Linking the Neoproterozoic and the Phanerozoic
}

Andrew S. Merdith ${ }^{1, *}$, Simon E. Williams ${ }^{2}$, Alan S. Collins ${ }^{3}$, Michael G. Tetley ${ }^{1}$, Jacob A.

Mulder $^{4}$, Morgan L. Blades ${ }^{3}$, Alexander Young ${ }^{5}$, Sheree E. Armistead ${ }^{6}$, John Cannon ${ }^{7}$, Sabin Zahirovic $^{7}$ and R. Dietmar Müller ${ }^{7}$

1 UnivLyon, Université Lyon 1, Ens de Lyon, CNRS, UMR 5276 LGL-TPE, F-69622, Villeurbanne, France

2 Northwest University, Xi'an, China

3 Tectonics and Earth Systems (TES) Group, Departtment of Earth Sciences, The University of Adelaide, Adelaide, SA 5005, Australia

4 School of Earth, Atmosphere and Environment, Monash University, Clayton, Victoria 3168, Australia

5 GeoQuEST Research Centre, School of Earth, Atmospheric and Life Sciences, University of Wollongong, Northfields Avenue, NSW

2522, Australia

6 Geological Survey of Canada, 601 Booth Street, Ottawa, Ontario, Canada \& Metal Earth, Harquail School of Earth Sciences, Laurentian University, Sudbury, Ontario, Canada

7 Earthbyte Group, School of Geosciences, University of Sydney, Sydney, New South Wales, 2006, Australia

Andrew.merdith@univ-lyon1.fr@AndrewMerdith

simon.williams@nwu.edu.cn

Alan.collins@adelaide.edu.au @geoAlanC

michaelgtetley@gmail.com @mikegtet

jack.mulder@monash.edu

morgan.blades@adelaide.edu.au

ajy321@uowmail.edu.au

sarmistead@1aurentian.ca@@geoSheree

john.cannon@sydney.edu.au

sabin.zahirovic@sydney.edu.au @tectonicSz

dietmar.muller@sydney.edu.au @MullerDietmar

This is the unformatted accepted manuscript published in Earth-Science Reviews

https://www.journals.elsevier.com/earth-science-reviews

DOI:

https://doi.org/10.1016/j.earscirev.2020.103477 


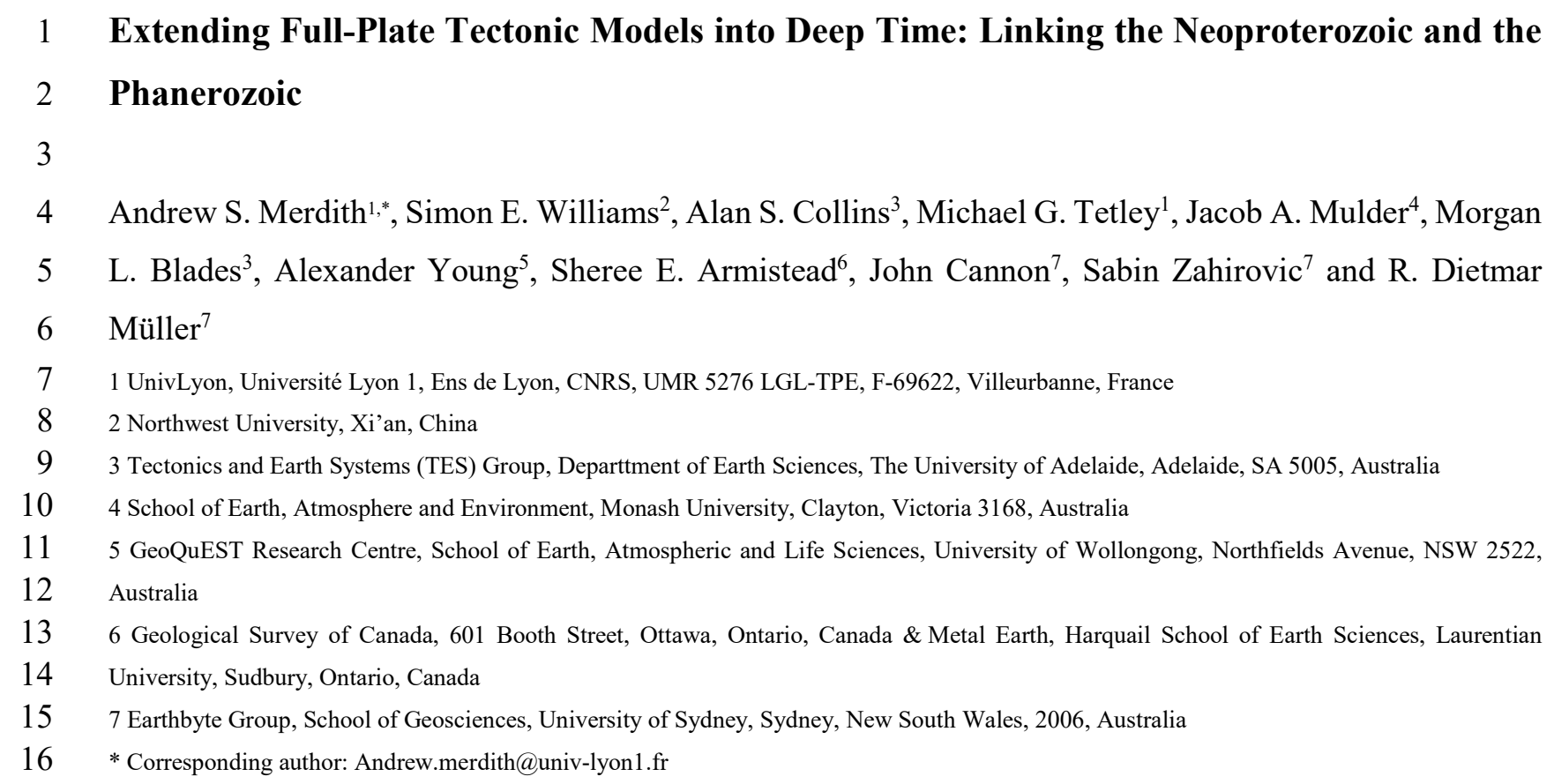

18 Abstract

Recent progress in plate tectonic reconstructions has seen models move beyond the classical idea of continental drift by attempting to reconstruct the full evolving configuration of tectonic plates and plate boundaries. A particular problem for the Neoproterozoic and Cambrian is that many existing interpretations of geological and palaeomagnetic data have remained disconnected from younger, better-constrained periods in Earth history. An important test of deep time reconstructions is therefore to demonstrate the continuous kinematic viability of tectonic motions across multiple supercontinent cycles. We present, for the first time, a continuous full-plate model spanning $1 \mathrm{Ga}$ to the present-day, that includes a revised and improved model for the Neoproterozoic-Cambrian (1000-520 Ma) that connects with models of the Phanerozoic, thereby opening up pre-Gondwana times for quantitative analysis and further regional refinements. In this contribution, we first summarise methodological approaches to full-plate modelling and review the existing full-plate models in order to select appropriate models that produce a single continuous model. Our model is presented in a palaeomagnetic reference frame, with a newly-derived apparent polar wander path for Gondwana from 540 to $320 \mathrm{Ma}$, and a global apparent polar wander path from 320 to $0 \mathrm{Ma}$. We stress, though while we have used palaeomagnetic data when available, the model

34 is also geologically constrained, based on preserved data from past-plate boundaries. This study is intended as a first step in the direction of a detailed and self-consistent tectonic reconstruction for the last billion years of Earth history, and our model files are released to facilitate community development. 


\section{Introduction}

Plate tectonics is a unifying theory of modern geology, explicitly connecting the evolution and processes that bridge the mantle, lithosphere, hydrosphere and atmosphere. Tectonic forces control the rates of uplift and erosion where continents collide or separate (England and Molnar, 1990) and modulate the flow of energy between oceans, lithosphere and mantle as continental configurations evolve (Bebout, 1995; Karlsen et al., 2019; Müller et al., 2008). Evolving plate tectonic configurations also determine changes in how species are distributed across different landmasses (McKenzie et al., 2014; Meert and Lieberman, 2008) and infer the rates of chemical flux between the Earth's surface and the deep interior (Gernon et al., 2016; Jarrard, 2003).

Global reconstructions have traditionally focussed on the positions of the major continents and geological terranes preserved within them. Data acquired from modern oceans provide a powerful constraint on the breakup of the supercontinent Pangea over the last ca. $200 \mathrm{Ma}$, and form the basis of continuous models of plate configurations from the Mesozoic to present (e.g. Müller et al., 2016; Seton et al., 2012). These 'fullplate' reconstructions use geological and geophysical data to determine the configurations and motions of both continental and oceanic lithosphere, and the nature of the plate boundaries that separate neighbouring plates. Together with the development of free software tools (Boyden et al., 2011; Müller et al., 2018), fullplate reconstructions permit quantitative estimates of tectonic processes through time within a continuous, consistent kinematic framework, opening up portions of Earth's history to quantitative analysis (e.g. Bower et al., 2013; Brune et al., 2017; Dutkiewicz et al., 2019; Hounslow et al., 2018; Karlsen et al., 2019; Merdith et al., 2019a).

Plate tectonic processes are thought to have been the dominant control on Earth's paleogeography possibly 62 since 3.2 Ga (Brenner et al., 2020; Brown et al., 2020a; Cawood et al., 2018a; Gerya, 2014; Palin et al., 63 2020). Studies of the pre-Pangean Earth have led to the proposal that Pangea was preceded by the 64 Proterozoic supercontinents Rodinia (Dalziel, 1991; Hoffman, 1991; Moores, 1991) and Nuna/Columbia 65 (Meert, 2002; Rogers and Santosh, 2002; Zhao et al., 2002) and earlier Archaean 'supercratons' (e.g. 66 Bleeker, 2003; Pehrsson et al., 2013; Smirnov et al., 2013), reflecting transient aggregations of continental 67 blocks interspersed between other phases of Earth's history when the continents were more dispersed. The absence of a pre-Mesozoic ocean floor record neccessitates that reconstructing the pre-Pangean Earth relies on the fragmented geological record preserved within the continents. Early studies of Proterozoic supercontinents provide individual snapshots of continental configurations; though there are differences 
between competing interpretations. More recently, attempts have been made to reconcile Neoproterozoic continental motions within a continuous kinematic framework (Cawood et al., 2020; Collins and Pisarevsky, 2005; Li et al., 2008). To further infer the extent and nature of tectonic boundaries covering all of Earth's surface in the Proterozoic requires methodical extrapolation of available observations and is subject to major uncertainties. Despite this, these reconstructions are valuable in that they make testable predictions about regions and time periods where observations are lacking.

Full-plate models published over the last decade collectively span the last $1 \mathrm{Ga}$. However, each of these models cover different time periods or areas of the world and each model is based on different assumptions and hypotheses, and place differing emphases on subsets of the geological record. Thus, although continental motions and plate boundary evolution have been categorised in some manner for the past $1 \mathrm{Ga}$, there is no fully continuous model defining Earth's tectonic history for this time. A fundamental test of any tectonic reconstruction for the Precambrian is that the configurations of continents, terranes and plate boundaries can evolve continuously as to seamlessly merge with reconstructed configurations for more recent times that are better constrained and ultimately tied to the present-day Earth. The absence of such continuous reconstructions highlights a critical uncertainty for assessing interpretations of Neoproterozoic

Our key motivations for this study are three-fold. Firstly, a $1 \mathrm{Ga}$ model will permit, for the first time, Neoproterozoic and Cambrian quantitative analysis that constrains (bio)geochemical and volatile fluxes, palaeoclimatic studies and the nature of earth systems, during times of biological evolution and extreme climate change (Gernon et al., 2016; Goddéris et al., 2017; Mills et al., 2011, 2019). Second, a full-plate model would be a starting point for future studies to constrain both the tectonic (e.g. supercontinent cycle (Li et al., 2019; Merdith et al., 2019b)) and geodynamic (e.g. core-lithosphere-mantle connection (Heron et al., 2020; Tetley et al., 2019)) nature and evolution of the Earth. Third, a consistent model for the Neoproterozoic and Cambrian that coherently links with younger models can be used as a framework to support future regional studies that test and enhance the resolution of the model or spawn alternative models that can be used for hypothesis testing. We stress that our reconstruction is intended to capture the main aspects of global tectonics across the last billion years and consequently lacks many details that could be incorporated for individual regions. Just as the earliest full-plate models for the Cenozoic and Mesozoic (Seton et al., 2012) and late Palaeozoic (Domeier and Torsvik, 2014) have provided valuable open-access

102 resources for numerous other studies to test and improve, we intend that the global framework provided by 103 our reconstruction will form the basis for future studies that will generate improved reconstructions by 104 incorporating new or different observations and ideas. 
106 This paper is organised as follows: first, we provide a review of the concepts behind full-plate 107 reconstructions, including the types of observations and assumptions on which they are based. We then

108 summarise the previously published reconstruction models and justify which elements of these existing 109 studies we have chosen to include in our reconstruction. Finally, we present the main outcome of our study: 110 the first continuous and self-consistent full-plate model from 1 Ga to present day with a single set of 111 polygons, Euler rotations and plate boundaries.

\section{Full-plate reconstruction models}

114 There are two broad categories of models that can be constructed to describe Earth's tectonic or 115 palaeogeographic history. The first category we refer to as 'continental drift' type models (Fig. 1a), as they 116 model the motion of continents drifting across the Earth's surface and tend to explicitly reflect 117 palaeogeography rather than tectonic evolution. The second type we refer to as 'full-plate models' (Fig. 118 1b), which, in addition to tracking the motion of continents, trace the evolution of plate boundaries and by 119 implication, the evolution of tectonic plates themselves (Gurnis et al., 2012). In effect, continental drift type 120 models are the precursor to full-plate models, but rather than supersede continental drift models, both types 121 of models complement each other and provide different avenues for research. Continental drift type models 122 are useful for analysing palaeomagnetic data, for contextualising regional studies or as a ground-breaking 123 study where there is little preserved data on plate boundaries. Comparably, full-plate models are more 124 encompassing, but are also much harder to iterate over and generate alternative models from. If one simply 125 requires the distribution of continental crust and not of plate boundaries, then it is much easier and simpler 126 to build a continental drift style model than categorically describe and model plate boundaries through time. 127 However, both types of models use the same reconstruction framework. 

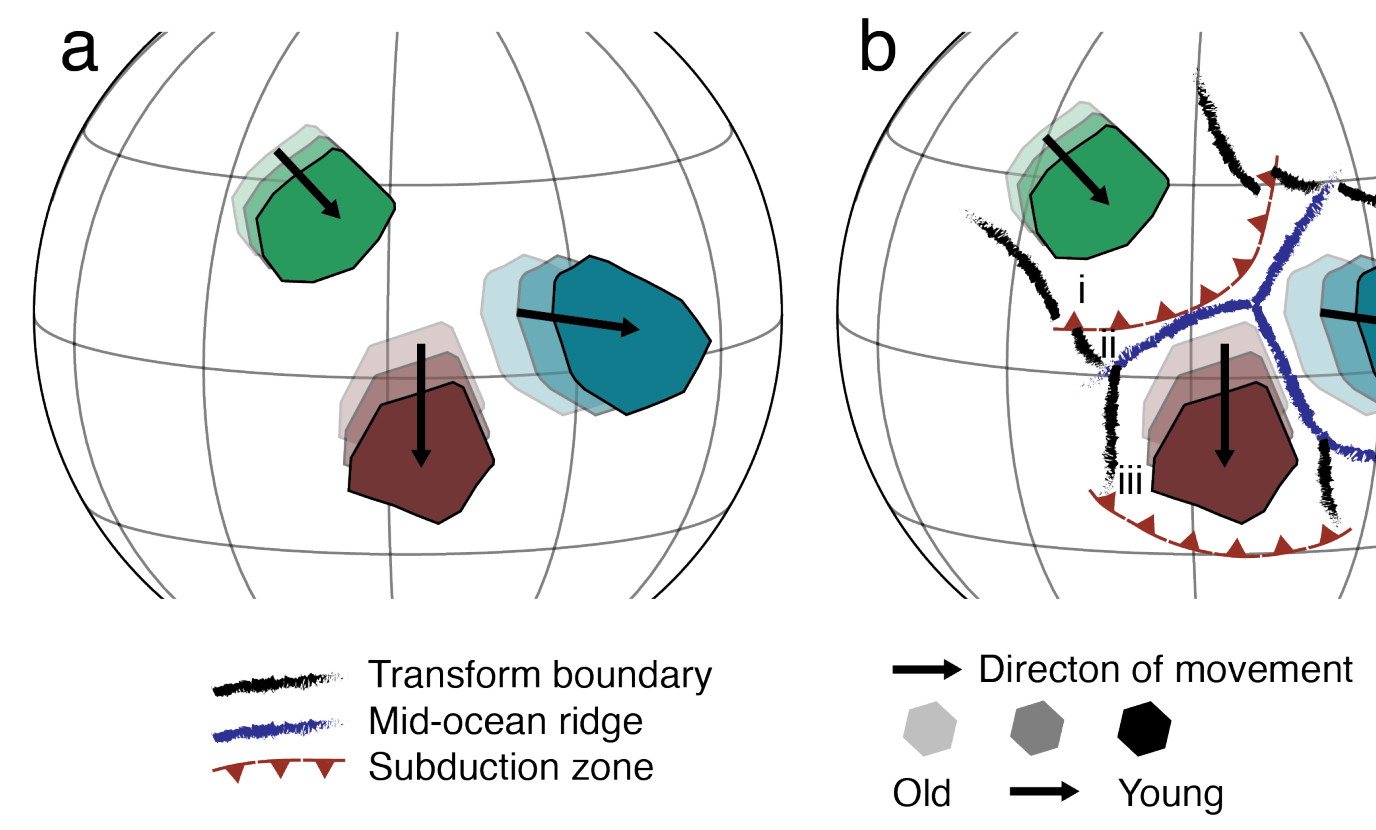

Figure 1

Schematic comparison of evolution of plate tectonic modelling. (a) 'Continental drift'/palaeogeographic type models and (b) full-plate models; (i)-(iv) identify separate plates. Palaeomagnetic data are the primary constraint of the movement of continents in both (a) and (b) however, the inclusion of geological data into the model in (b) preserves the relative type of motion between two continents (divergence, convergence or transform) and allows for the construction of plate boundaries.

\subsection{Reconstruction Framework}

133 The essential characteristic of any plate reconstruction is the reconstruction framework (or network

134 (Domeier and Torsvik, 2017)), which is the organisation of data used to describe the motion of rigid objects

135 on a sphere using Euler's rotation theorem (McKenzie and Parker, 1967; Morgan, 1968). In plate

136 reconstructions, the rigid objects in motion are the plates themselves and, in addition to requiring the

137 temporal and spatial components of moving plates (i.e. the time period of motion, latitude, longitude and

138 angle of rotation) the theorem also requires that each rotation be defined relative to another object. This

139 rotation of one object relative to another forms the basis of a 'relative plate motion model'. It is also

140 desirable for these relative rotations to be tied to something (relatively) immutable within, or around, the

141 Earth (e.g. the core, mantle, or the spin-axis) thus, transforming the model into an 'absolute plate motion

142 model'. For the Mesozoic and Cenozoic, plates are described in a relative framework due to the preservation

143 of oceanic lithosphere within oceans formed since the breakup of Pangea. In this way each plate's motion

144 history is described as moving relative to another plate, with the African plate typically at the top of the

145 hierarchy (e.g. (Ross and Scotese, 1988; Torsvik et al., 2008); Fig. 2a, b). The motion of the African plate 
can then be defined absolutely (though using observations from many or all plates, and not just Africa) to the deep Earth through alternative methods such as hotspot chains (Müller et al., 1993; O’Neill et al., 2005), seismic imaging of subducted slabs (van der Meer et al., 2010), palaeomagnetic data (with or without true polar wander corrections, Torsvik et al., 2012) or methods jointly evaluating the characteristics of multiple constraints including plate velocities, hotspot chains and subduction trench migration (Tetley et al., 2019). Regardless of which method is chosen, the result is a global reference frame defined as a sequence of absolute motions of the African plate, which, together with the relative motions between plate-pairs arranged within a hierarchy (Fig. 2), define the absolute motions of all plates. An exception to all plates being tied to Africa occurs for the Mesozoic Pacific Ocean. Before $83 \mathrm{Ma}$ (and the opening of the West Antarctic spreading centre) the motion of the Pacific plate is preserved and reconstructed absolutely to the spin axis through hotspot motion, rather than through Africa. Plate models can also be described in a purely relative framework, in which case a single continent (or plate) is fixed to its present-day position and all other continents or plates are rotated relative to the fixed plate. This approach is commonly used for localised studies or to easily highlight the difference between two contrasting models (Fig. 2c).

Before the Mesozoic era, it is not possible to use preserved, in situ oceanic lithosphere, hotspot motions and seismic imaging of slabs. Therefore, the logical arrangement of connections within the rotational framework changes (Domeier and Torsvik, 2017), however the general principles of plate reconstructions remain the same. For these times, the only quantitative information on the positions of plates is through palaeomagnetism, which describes the palaeolatitude of continents with respect to the Earth's spin axis. In these cases, where the absolute motions are more directly constrained than relative motions, rotation models traditionally favour a simpler hierarchy, rather than the complex hierarchies used for post-Pangea times (e.g Fig. 3a, b). The motion of major continents relative to the spin axis is determined using their own palaeomagnetic data (Fig. 3a, b). Within this data set, continents can be grouped together in localised hierarchies where there is evidence that they have remained together or close to one another or, in instances where paleomagnetic data are lacking from some of the blocks if geological constraints permit.

Finally, although Euler's rotation theorem is based on the motion of rigid bodies, this is a simplification because the lithosphere is deformable. Recent advancements in plate modelling (Gurnis et al., 2018) have allowed for the development of deforming plate models where rigid plates are able to deform along their edges. 


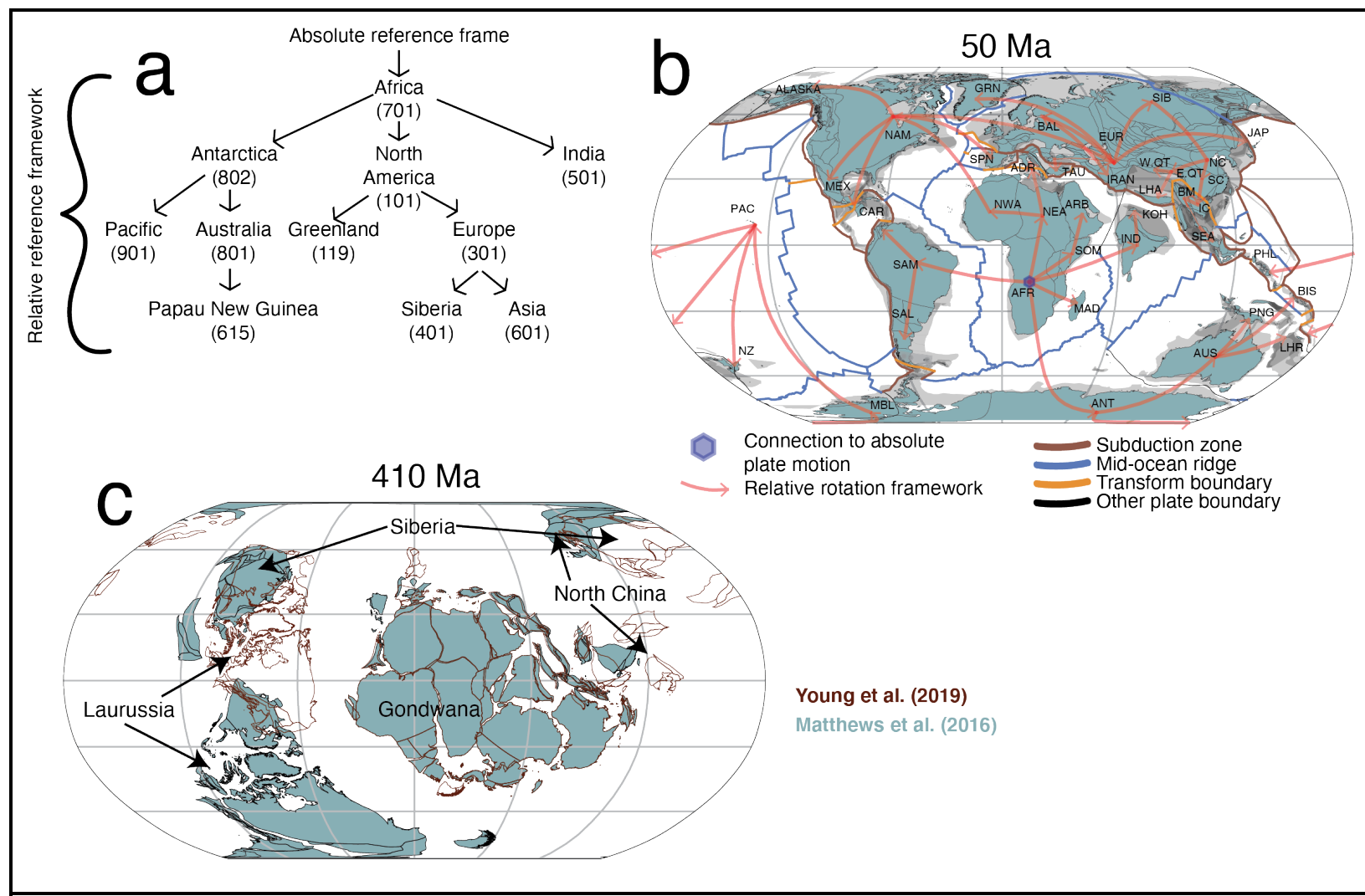

Figure 2

Overview of the rotational framework of a relative plate motion model. (a) Schematic of the 'tree' like hierarchy (e.g. Ross and Scotese, 1988) from the Matthews et al. (2016) reconstruction, where the motion of all plates are defined relative to the African plate at $50 \mathrm{Ma}$. (b) A simplified map view of the hierarchy in (a). The African stage pole (blue hexagon) is at the top of the hierarchy and connected to the absolute plate motion model that describes the movement of the African plate (in this case, as a proxy for the entire globe) to the deep earth. (c) Example of plate motion with a continent (Africa) fixed in its presentday position. Fixed plate presentations enable observations of relative motions between the fixed continent or plate and another. Hence, they are useful to constrain relative plate motions and also compare two or more different plate models. In this instance, a key difference between the model of Young et al. (2019) and Matthews et al. (2016) is highlighted in the spatial relationship between Laurussia and Gondwana at 410 Ma. In Domeier and Torsvik (2014) (which is preserved in Matthews et al. (2016)) Laurussia is proximal to southwest Gondwana while in Young et al. (2019) it is positioned to the northwest. ADR, Adria; AFR, Africa; ARB, Arabia; AUS, Australia; BAL, Baltica (cratonic Europe); BM, Burma; CAR, Caribbean; E.QT, East Qiangtang; EUR, Europe; GRN, Greenland; IC, Indochina; IND, India; JAP, Japan; KOH, Kohistan arc; LHA, Lhasa; LHR, Lord Howe Rise; MAD, Madagascar; MBL, Marie Byrd Land; MEX, Mexico; NAM, North America; NC, North China; NEA, Northeast Africa; NWA, Northwest Africa; NZ, New Zealand; PAC, Pacific; PHL, Philippines; PNG, Papua New Guinea; SAL, Salado Microplate; SAM, South America; SC, South China; SEA, Southeast Asia; SIB, Siberia; SOM, Somalia; SPN, Spain; TAU, Taurides; W.QT, West Qiangtang. 
Palaeolatitude is determined through the study of palaeomagnetic data and is the only method to

184 quantitatively constrain the absolute latitudinal position of a continent for pre-Jurassic times. If sufficient

185 data are present from a single continent, an apparent polar wander path (APWP) can be constructed that

186 describes the motion of that continent through time (Torsvik et al., 2012). If there are very good geological

187 constraints on the relative positioning between multiple continents, then poles from these continents can be

188 merged to form composite apparent polar wander paths. This merging is done by rotating the poles of

189 multiple continents into the coordinate frame of a single continent, typically found higher in the framework

190 (e.g. Africa, Fig. 2a). If this process is done using all global data it is known as a global apparent polar

191 wander path (GAPWaP). GAPWaPs provide the potential for a more rigorous description of the evolution

192 of a suite of continents as more data are available.

194 There are, however, many caveats and uncertainties associated with GAPWaPs and APWPs that contain 195 data sourced from more than one continent (e.g. APWP for Gondwana). In particular, they are strongly 196 dependent on the relative position of continents, as even minor changes in these relative positions can result 197 in large differences in the resulting wander paths. They also are directly dependent on the quality and 198 abundance of palaeomagnetic data, thus a degree of subjectivity can be introduced by what criteria are used 199 for selecting and filtering poles (Van der Voo, 1990; see a new approach in Wu et al., 2020). For example, 200 in the Gondwana APWP of Torsvik et al. (2012) (and also for the APWP we construct in this paper), there 201 is one pole for Gondwana between 440 and 400 Ma that constrains the motion of over half of all known 202 continental crust at the time. In the Precambrian, the geological uncertainty of exactly how two cratons (or 203 continents) fit together limits the usefulness of GAPWaPs and APWPs that are defined by multiple continents in conjunction with one another. Instead individual APWPs can be constructed using available palaeomagnetic data for continents and then these are all balanced together globally to produce a coherent

206 kinematic continental model (e.g. Li et al., 2008; Pisarevsky et al., 2014). In this manner, it is possible to 207 build continental drift models purely from palaeomagnetic data. 


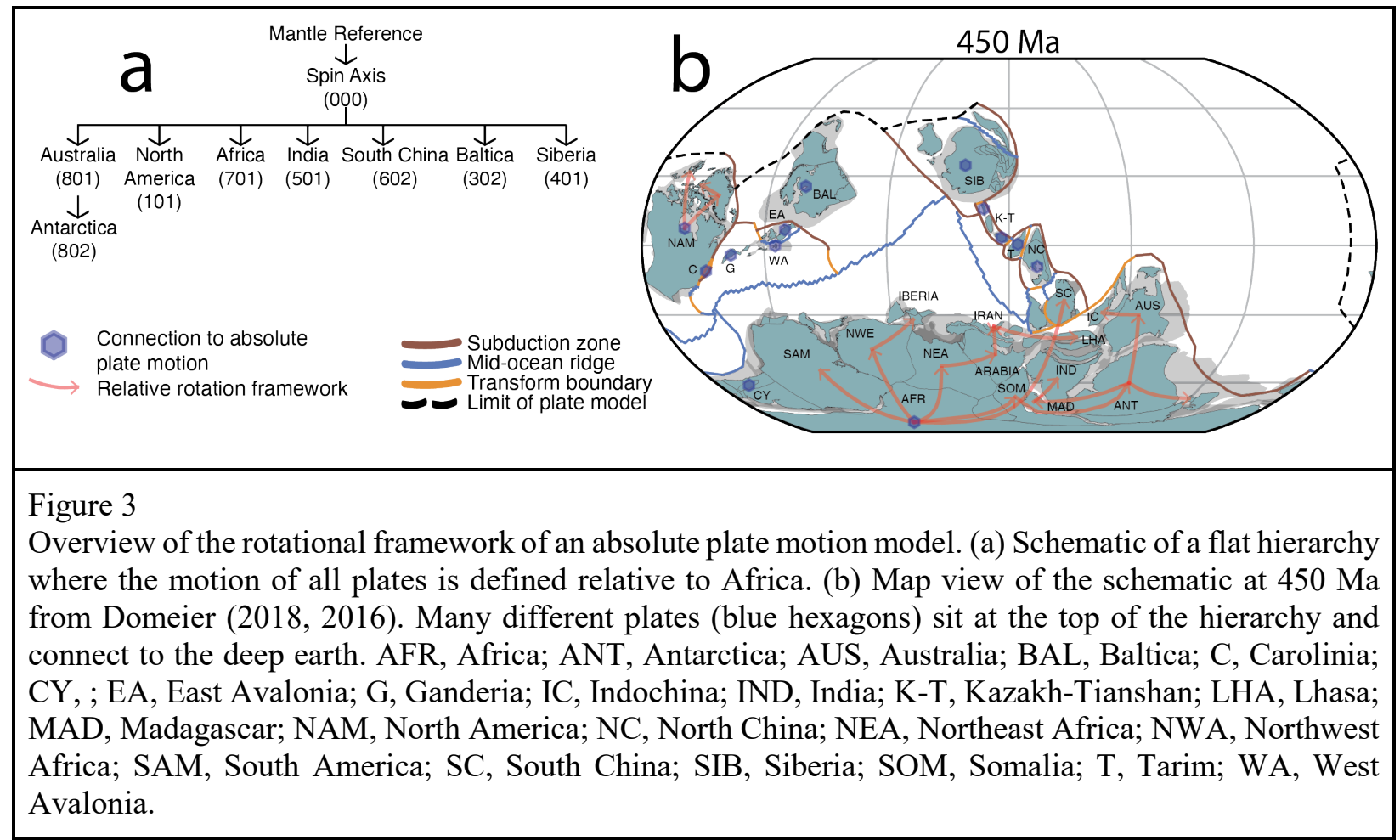

\subsection{True Polar Wander}

212 True polar wander (TPW) is the motion of the entire solid Earth (mantle-lithosphere) with respect to the

213 spin axis due to centrifugal forces from Earth's orbit acting on mass anomalies in the upper mantle, wherein

214 positive anomalies are driven towards the equator and negative anomalies towards the poles (Evans, 2003).

215 Since TPW is inherent in palaeomagnetic data, all APWP are a composite of both plate motions and some 216 component of TPW. Thus, in the strictest sense, to properly use a plate model for geodynamic modelling,

217 a correction that removes any component of detected TPW should be applied (i.e. the mantle reference

218 frame). Further, as the mass anomalies in the mantle are thought to arise from the flow induced by subducted 219 oceanic lithosphere and the associated return flows, TPW excursions are closely linked to the supercontinent cycle (Zhong et al., 2007).

222 Raub et al. (2007) identified three types of TPW summarised briefly below, though only the latter two are relevant here. Type 0 TPW operates on short $\left(<10^{3} \mathrm{a}\right)$ timescales as a response to elastic deformation within

224 the lithosphere arising from seismic events (Soldati et al., 2001) and so has a negligible effect on plate motions on the timescales pertinent here (Evans, 2003; Raub et al., 2007). Type 1 TPW is the most

226 important to consider, and is broadly defined as the slow motion of the solid Earth (mantle and lithosphere)

227 readjusting to mass anomalies in the mantle. Type $1 \mathrm{TPW}$ is what is commonly detected and corrected in 
plate motion models (Steinberger and Torsvik, 2008; Torsvik et al., 2012) in order to constrain geodynamic relationships between deep Earth processes and tectonics (Mitchell et al., 2012). Type 2 TPW (InertialInterchange True Polar Wander, IITPW) was originally described by Kirschvink (1997) and is a hypothesis where the mantle and crust are rapidly displaced over large distances relative to the spin axis as the moment of minimum inertia $\left(I_{\min }\right)$ approaches the maximum moment of inertia $\left(I_{\max }\right)$ resulting in an interchange

233 between the two (i.e. $I_{\min }$ becomes $I_{\max }$ and vice versa). IITPW has been linked to supercontinent breakup 234 as continental lithosphere and subduction zones move away from the upwelling, known as a superswell, 235 developing beneaththe supercontinent, which is assumed to remain quasi-stable (Li et al., 2004). In the Li et al. (2004) model, the superswell is likely to maintain the $I_{\max }$, but as all the continents move away $I_{\min }$ approaches $I_{\max }$, thus they are speculated to interchange with each other.

The primary challenge of subtracting the effects of TPW from APW paths is identifying and separating TPW components from continental motion. Methods of detecting TPW vary, either isolating it directly from palaeomagnetic data (Mitchell et al., 2012) or deconstructing the APWP of continents by comparing the kinematic motions of all continental lithosphere on the globe to isolate TPW (Steinberger and Torsvik, 2008). Both approaches require a priori assumptions stemming from the choice of plate model being analysed, which makes it impossible to apply a TPW correction from one model to another. For example, fitting a great circle to palaeomagnetic data following the approach of Mitchell et al. (2012) is dependent on knowing the relative continental configuration from which the palaeomagnetic data are sampled. Alternatively, deconstructing the motions of the continents after Steinberger and Torsvik (2008) is dependent on constraining absolute palaeolongitude to separate TPW from apparent polar wander. In order to support their arguments, both methods are dependent on having some form of absolute palaeolongitudinal control.

\subsection{Palaeolongitude}

253

There is no well-established method to compute the absolute palaeolongitude of any given plate that is applicable to pre-Jurassic times. However, two hypotheses have been proposed for establishing absolute palaeolongitude for pre-Pangea reconstructions (Torsvik and Cocks, 2017): (i) the plume generation zone method (PGZ) (Torsvik et al., 2014) and (ii) the orthoversion model of the supercontinent cycle (Mitchell et al., 2012).

259

260 The PGZ method is based on reconstructing the surface locations of kimberlites and large igneous provinces 261 (LIPs) to the margins of the large low shear velocity provinces (LLSVPs) (Burke and Torsvik, 2004; 
Torsvik et al., 2010a) situated on the core-mantle boundary (CMB) (Garnero et al., 2007; Li and McNamara, 2013). The foundation for this method is the observation that kimberlites and LIPs, when restored to a mantle reference frame at the time of eruption, are positioned preferentially above the margins of the LLSVPs (Burke and Torsvik, 2004; Torsvik et al., 2010a). LLSVPs are regions of anomalously slow (slower than ambient mantle) seismic velocities, close to the core-mantle boundary. Since large-scale mantle structure is intimately related to the supercontinent cycle, LLSVPs (Li and Zhong, 2009) are thought to exist for (at least) a similar time frame as the supercontinent itself (i.e. present-day LLSVPs are thought to have existed at least back to $320 \mathrm{Ma}$ ) (Li and Zhong, 2009), but not necessarily maintaining their presentday geometry (Flament et al., 2017; Zhang et al., 2010; Zhong and Rudolph, 2015).

The PGZ method to establish absolute palaeolongitude therefore assumes: (i) the geometric stability of the present-day positions of LLSVPs back to the time of interest, and (ii) that there is a positive statistical correlation with margins of LLSVPs and the extrusion of LIPs and kimberlites at the Earth's surface. Adopting the PGZ method allows one to position continents longitudinally by reconstructing the positions of LIPs and kimberlites to overlie the margins of LLSVPs while simultaneously utilising TPW-corrected palaeomagnetic data (Torsvik et al., 2014). In this way, models with explicitly defined and reproducible absolute plate motions can be created (Domeier and Torsvik, 2014). However, a number of recent studies have raised questions about the assumptions implicit in the PGZ approach. For example Flament et al. (2017) and correspondence by Torsvik and Domeier (2017), Doucet et al. (2020), Zhong and Rudolph (2015) and Zhong and Liu (2016) on long term LLSVP stability and Austermann et al. (2014), Davies et al. (2015), with response by Doubrovine et al. (2016) on the statistical correlation. Consequently, while utilising the PGZ method for plate reconstructions in the Palaeozoic is currently an open area of research, the theoretical and practical application for Precambrian times remains untested.

The other proposed method of determining absolute palaeolongitude for deep time reconstructions is known as the 'orthoversion model' and suggests that successive supercontinents coalesce orthogonally $\left(90^{\circ}\right.$ longitude) above the downwelling formed by subduction at the margin of the previous supercontinent (Mitchell et al., 2012). Mitchell et al. (2012) test their model by first determining the minimum moment of inertia $\left(I_{\text {min }}\right)$ during each phase of supercontinent assembly. This is done by rotating the available paleomagnetic data into a relative reference frame of a fixed continent (Africa for the Phanerozoic, Laurentia for the Neoproterozoic) and then fitting a great circle to the resulting poles. $I_{\min }$ is defined as the orthogonal axes (or pole) of the great circle and is taken to approximate the TPW axis. Mitchell et al. (2012) fitted great circles to palaeomagnetic data for a selection of time periods (1165-1015 Ma, 805-790 Ma, 550-490 Ma and 220-90 Ma) and calculated that the angle between each successive $I_{\min }$ was $\sim 90^{\circ}$; as 
expected in the orthoversion model. The initial (palaeolongitudinal) placement of Pangea is constrained from its position at $\sim 90 \mathrm{Ma}$ (centroid of $\mathrm{I}_{\min }$ at $0^{\circ} \mathrm{N}, 10^{\circ} \mathrm{E}$ ) when the most recent TPW episode finished (Steinberger and Torsvik, 2008). Therefore, during Rodinia and Gondwana, when $I_{\min }$ was $90^{\circ}$ from present day, Mitchell et al. (2012) proposed that the centre of mass of both was positioned at $100^{\circ} \mathrm{E}$.

As with the PGZ, a number of limitations are apparent with the orthoversion model. In particular, the method of Mitchell et al. (2012) does not separate continental motion from true polar wander when calculating $I_{\min }$, thus it assumes that during these times TPW is the primary signal recovered from palaeomagnetic data and not continental motion. Secondly, the orthoversion model is inherently dependent on both the quality and abundance of palaeomagnetic data (e.g. the Rodinia $I_{\min }$ in Mitchell et al. (2012) is based on only three poles), as well as the continental configuration of the time (as the continental configurations can determine the relative position of palaeomagnetic data when rotated into a specific reference frame). Torsvik and Cocks (2017) highlight this succinctly by using slightly different palaeomagnetic data, and a slightly different Gondwana configuration to produce an $I_{\min }$ between 550 and $490 \mathrm{Ma}$ of $50^{\circ} \mathrm{S}, 64^{\circ} \mathrm{E}$ (compared to the estimate of Mitchell et al. (2012) of $30^{\circ} \mathrm{S}, 75^{\circ} \mathrm{E}$ ). Finally, the calculation of $I_{\min }$ at each time step occurs within a fixed relative reference frame (i.e. Fig. 2c), meaning that the $I_{\min }$ itself cannot be restored to an absolute palaeogeographic position. Thus, the longitudinal centre

\subsection{Geology}

Geology is unfortunately silent on the absolute positioning of continents in time, except in circumstances such as the PGZ method discussed above. However, it contains a wealth of information of relative plate motions in the Mesozoic and Cenozoic (e.g. seafloor spreading), and in deeper time through the temporal evolution of sedimentary basins and facies, and tectonic affinities inferred from geochemistry, zircon arrays, magmatism and metamorphism. However, geology does have an advantage over palaeomagnetic data in that there are many different types of data available, especially from small and minor terranes in the Precambrian that are otherwise unconstrained palaeomagnetically. Given the wealth of geological data, especially in the Neoproterozoic, there is a general hierarchy of use that is a reflection of the scale of the problem. Our approach is to start by building a global framework and work progressively to finer resolution to inform the localised nature of that framework. 
The first and most important geological data to gather is evidence of rifts and arcs, as they describe

330 separation (usually leading to seafloor spreading) and convergence, respectively and can therefore put in

331 place the framework for plate motions and subsequent interpretation of geological data. Secondly,

332 identifying piercing points where geological boundaries can be matched on now separate continents (e.g.

333 Appalachians and Gondwana forming orogenies), or ways of fitting two continents together in a stable

334 configuration. These piercing points are important because reconstructing continental configurations with

335 high confidence allows the generation of more rigorous APWPs and they help to constrain the location and

336 orientation of both rifts and arcs on the periphery of continents. Unfortunately, due to deformation and

337 progressive alteration of continental crust (e.g. changes of continent-ocean boundaries (COBs)), in pre-

338 Gondwana times it is difficult to be more precise than matching the margins of large continents and for

339 smaller cratons and terranes it is almost impossible. A pertinent example of this are the four different

340 proposed configurations of Australia and Laurentia during Rodinia (see reviews by Li et al., 2008; Merdith

341 et al., 2017b), which all broadly match the same margins against each other (east coast of Australia with

342 the west coast Laurentia, with or without an intervening continent) but place them in different relative 343 positions.

After arcs and rifts, we can loosely (but not exhaustively) group geological features and data based on their applications. Sedimentary basins, dyke swarms, detrital minerals, geochemical signatures and fossils are

347 typically used to determine provenance or latitudinal band and align once contiguous regions. The timescales and conditions of metamorphism together with structural data can be used to infer the tectonic setting and polarity of collisional events or help constrain the nature of indeterminate plate margins such as transform boundaries. These types of data assist in increasing the resolution of a plate model by understanding the geology at smaller scales within the framework of a specific tectonic setting, such as an arc or rift. We stress here that the relationship between detailed regional geology and the broader framework of a plate model is not a 'one-way street' but is highly iterative. If, for example, a detailed geological study determines that an interval of magmatism and sedimentation that was originally interpreted as a failed rift, in fact led to seafloor spreading, then the broader scale tectonic framework and plate model must be reevaluated. Finally, due to the qualitative nature of most geological data, the iteration and implementation of these data into the plate model typically necessitates qualitative decisions that others may disagree with. Iteration over the model continues until we approach tectonic congruency within the model (i.e. data-based iterations in one part of the world do not nullify data in other areas of the world). We stress that this does

360 not mean our model is 'correct' or 'true', just that it is internally consistent with as much data as possible.

361 Consequently, we consider the model presented here a viable, but non-unique interpretation of 362 Neoproterozoic data. 
364 A specific example of the importance of interpreting geology within a full-plate framework is given by 365 recent work on the Stenian-Cryogenian evolution of the East African Orogen. Although arc-related 366 magmatism has been recognised in the northern East African Orogen for a number of decades (e.g. Stern, 367 1994), the recognition of similar-aged arc magmatism in the higher-grade southern East African Orogen of 368 Madagascar, Southern India and East Antarctica has been more controversial and under-appreciated until 369 recently (Archibald et al., 2018, 2017; Armistead et al., 2019; Plavsa et al., 2015; Ruppel et al., 2018). In 370 one particular example, work over the last decade on Western Dronning Maud Land in East Antarctica has 371 identified an extensive Stenian-Tonian juvenile arc system (named TOAST; (Elburg et al., 2015; Jacobs et 372 al., 2015; Ruppel et al., 2018)). This discovery has gone hand-in-hand with the recognition of a similar 373 region in western Madagascar, known as the Dabolava Arc (Archibald et al., 2017; Tucker et al., 2011)

374 (e.g. Fig. 8). These arcs are now separated by a considerable distance, but their reconstructed position in 375 the Neoproterozoic and their similarity has led to us interpreting them as part of one continuous subduction 376 system that was active for the Stenian and Tonian. In this manner, we now include TOAST as another part 377 of Azania and have reworked a number of the plate boundaries in Merdith et al. (2017a) to reflect these new geological data and tectono-geographic interpretations.

\subsection{Kinematic considerations}

The final line of reasoning used to create full plate models are plate kinematic constraints. These are not defined explicitly through geological or geophysical data of the types outlined above, but rather come from the idea that the evolution of plate motions through time must follow the broad principles of plate tectonics in a way that would seem reasonable; for example, by equivalency with more recent and well-constrained plate motions. The most basic requirement is that continental blocks cannot pass through or significantly overlap other continents and we must be able to describe the position and motion of each continental block for as long as the crust within that block is thought to have existed. While this may seem obvious, these considerations present a powerful method for discriminating between competing reconstruction scenarios. Models constructed for deep time that cannot evolve towards more recent and present-day configurations of continents cannot be considered correct. Similarly, models requiring an implausible kinematic evolution

392 in order to meet present-day configurations cannot be correct. A tangible example is Rodinia, for which a 393 range of configurations could be permissible based on available paleomagnetic and geological data (see 394 reviews in Evans, 2013; Li et al., 2008; Merdith et al., 2017b). However, analysing the sequence of plate 395 motions required to translate each continent to their (better constrained) positions during the Palaeozoic is 396 more plausible in some of these scenarios than others, such as not requiring individual terranes or blocks to 
cross multiple ocean basins or navigate their way around a stable continent (Merdith et al., 2017b). Further examples where kinematic constraints add useful insights are when constructing models that explicitly trace the evolution of plate boundaries and tectonic plates. An example is expressed in the logic of Domeier

400 (2018) who inferred that the longitudinal position of Tarim, North China and South China during the late 401 Cambrian-Devonian must have remained stable relative to one another, because palaeolatitudes from 402 palaeomagnetic data overlapped and therefore must be consistent with their end position in the more well 403 constrained Devonian-Triassic.

Finally, we take a uniformitarian view of tectonic evolution, in that we assume that plate tectonics and relative plate motions were operating on similar principles in the Neoproterozoic to what we can observe in the Mesozoic and Cenozoic. During more recent times, the motion of plates remains relatively constant for time lengths on the order of 10-100 Ma, with changes in motion occurring comparatively quickly $(<3$ $\mathrm{Ma}$ ) and tied to an event further afield, such as terrane collision in a subduction zone, subduction onset, rifting onset or ridge subduction (e.g. Austermann et al., 2011; Cawood et al., 2016; Cawood and Buchan,

414 Within palaeomagnetic data, this approach is exemplified in Torsvik et al. (2008), where filtered compilations of data result in smooth APWP segments punctuated by cusps in motion and velocity, and more recently by $\mathrm{Wu}$ et al. (2020). For the Neoproterozoic, which has much more sparse palaeomagnetic 417 data coverage than the Phanerozoic, the logic can be applied by linking changes in plate direction (as 418 suggested or necessitated by palaeomagnetic data) directly to geological evidence of a change in tectonic regime within the region of interest (e.g. Merdith et al., 2017b).

\subsection{Synthetic Ocean Plates}

A complete full-plate model by definition includes a representation of the evolution of ocean basins through time. This is the most uncertain part of any full-plate model. With a few exceptions (e.g. Granot, 2016), no pre-Jurassic ocean crust is preserved in situ, so that even where we can infer the presence of divergent plate boundaries (for example, following continental breakup), the precise geometry and spreading rates at these boundaries are conjectural. Consequently, there are no unique solutions to the definition of these boundaries and the synthetic ocean plates constructed from them. The main aim in the reconstruction of ancient ocean

429 basins is to ensure that the synthetic plates and plate boundaries are at least consistent with sparse 430 observations preserved on the continents. 
432 Firstly, although we have little data on the creation of oceanic lithosphere for pre-Jurassic times, the 433 geological record does preserve data on the consumption of oceanic lithosphere at subduction zones. The 434 most important criteria that therefore must be met are that (i) (sub-) orthogonal divergence occurs at mid435 ocean ridges and that (ii) convergence occurs at subduction zones (Domeier and Torsvik, 2014). The former 436 of these two criteria typically occurs between continents during supercontinent breakup or when small 437 terranes rift from a continent (Dalziel, 1997). The latter of these includes subduction along the margins of 438 continents as well as within intra-oceanic arcs. Thus, these two criteria necessitate the extrapolation of 439 known plate boundary positions (e.g. preserved continental arcs, rift zones) into larger areas to ensure the 440 tectonic congruency of the model (in this case, that convergence or divergence at one location doesn't 441 nullify the same criteria in another location). It is this step, in particular, that requires significant iteration 442 when constructing a model. Maintaining tectonic congruency for a model is best achieved when the 443 extrapolation of plate boundaries is done as simply as possible. For example, in reconstructing an ocean 444 basin without any continental crust (e.g. Pacific Ocean, Panthalassa Ocean), a triple junction is usually the 445 simplest expression of a ridge system that ensures divergence in all directions and convergence at its 446 margins (Domeier and Torsvik, 2014). The evolution of such a triple junction could also be seen in the 447 Ediacaran opening of the Iapetus Ocean (e.g. Pisarevsky et al., 2008; Robert et al., 2020),

\section{Model selection and justification}

\subsection{Existing plate models}

The selection of which full-plate model to assist in solving a problem is dependent on the nature of the problem, as each published plate model is constructed using a different approach and has a different reconstruction framework. For example, a study looking at absolute plate motions of the Cenozoic has little use for models connected to the Palaeozoic or Neoproterozoic. Instead, such studies typically include a comparison with previously published models as well as a rigorous mantle reference frame. Similarly, a study that traces the latitudinal distribution of continental arcs through the Phanerozoic has no need for a mantle reference frame and a study investigating the changes in net rotation through time would be concerned with small, localised improvements from regional models but more focussed on capturing the large scale changes that occur when continents breakup. Although newer plate models typically address the shortcomings of previous models or implement more refined updates of regional areas, this does not necessarily make them better for all applications. Older plate models have been more rigorously tested and used by the community and as one travels further back in geological time, the data are more ambiguous and 
can invite alternative interpretations. For the purpose of this study, the existing plate models we consider

466 are only those that are publicly released with fully self-consistent with coherent plate motions and plate 467 boundaries. Thus, we omit many models that provide only continental motions (Scotese, 2016; Torsvik and 468 Cocks, 2016), alternative or regional Rodinia configurations (Evans, 2013) or regional refinements of 469 global models for the Mesozoic and Cenozoic (e.g. Vaes et al., 2019).

470

471 The major step forward for producing full-plate models was the construction of open-source computer 472 software specifically designed to work with full-plate reconstructions (e.g. GPlates; (Gurnis et al., 2012). 473 Following their development, GPlates-compatible global models for the Early Jurassic to present (Seton et 474 al., 2012; Shephard et al., 2013) and a model for the Late Palaeozoic (Domeier and Torsvik, 2014) soon 475 followed (hereafter, SET12 and DT14, respectively). Subsequent work by Matthews et al. (2016) (MAT16) 476 bridged the gap between the Palaeozoic and Jurassic, linking a slightly modified version of DT14 with an 477 updated SET12 model, the Müller et al. (2016) model (MUL16). Further back in time, two models for the 478 Early Palaeozoic (500 to 410 Ma) now exist: Domeier (2016) (DOM16), which encompasses the evolution 479 of the Iapetus and Rheic Oceans, as well as the motion of Gondwana, and Domeier (2018) (DOM18), which 480 models the evolution of the first generations of Tethyan Oceans and Central Asian blocks (Siberia, North 481 and South China, Tarim). For the Neoproterozoic, Merdith et al. (2017a) (MER17) produced a full-plate 482 model from 1000 to $520 \mathrm{Ma}$, using the models of continental motion presented by Li et al. $(2013,2008)$ as 483 a base. An alternative reconstruction from the late Palaeozoic to present-day has been presented by Young 484 et al. (2019) (YOU19). YOU19 offers an alternative full-plate model for the Palaeozoic to the DT14 and 485 MAT16 models that does not rely on the PGZ method. Finally, a deforming plate model was produced 486 (Müller et al., 2019) (MUL19) that modelled rift and convergence deformation from 250 to 0 Ma. Table 1 487 summaries the main features of these models. 


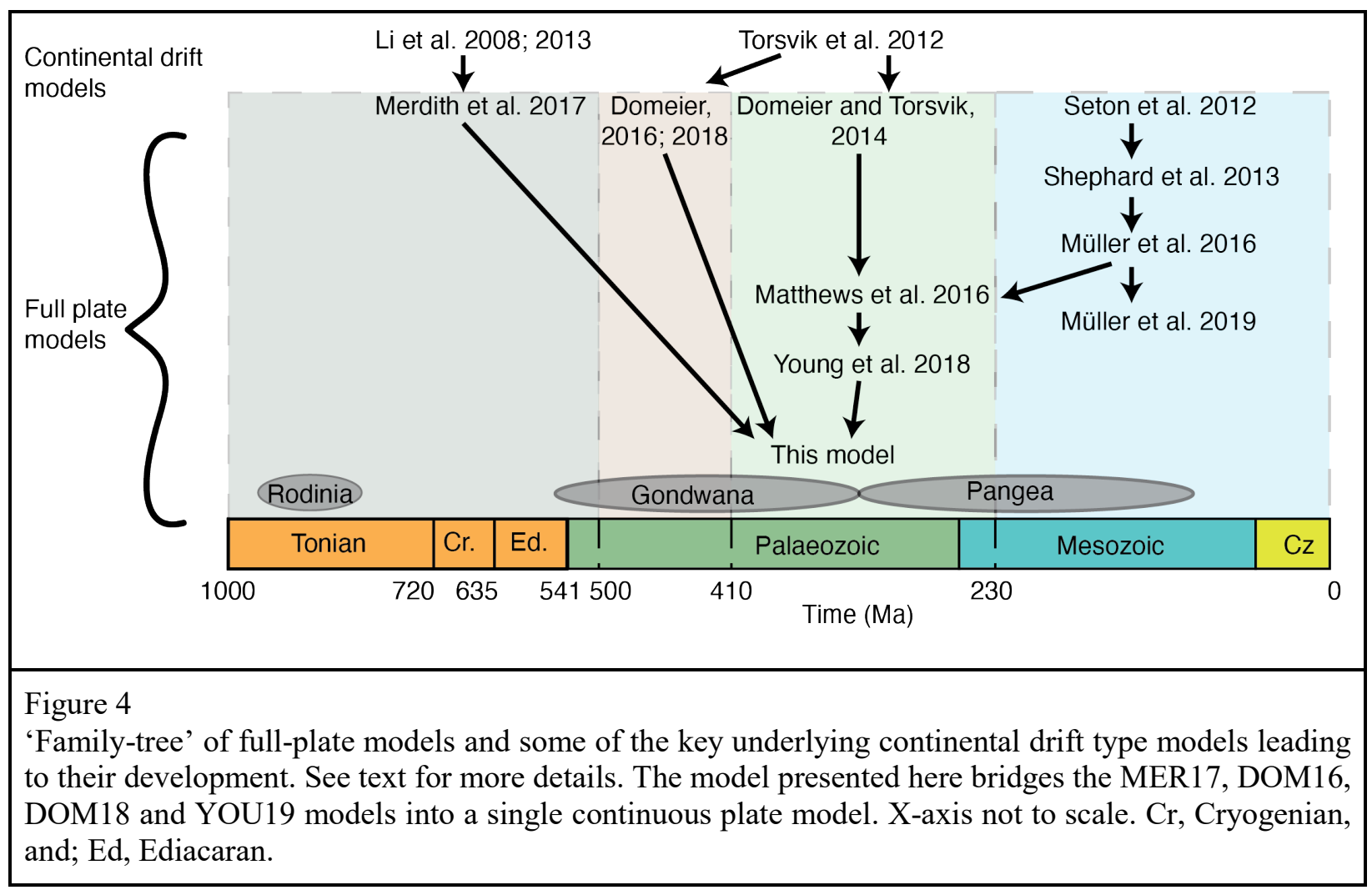

\subsection{Cenozoic and Mesozoic plate models}

We consider three plate models for the Cenozoic and Mesozoic: SET12, MUL16, and MUL19 (Fig. 4). The SET12 model spans from present-day to $200 \mathrm{Ma}$, with MUL16 and MUL19 extending back to 230 and 240 Ma, respectively. The main geological constraint of these models are the magnetic lineations preserved in oceanic crust that describe the relative movement between the pairs of continents breaking apart during the fragmentation of Pangea. The evolution of the Atlantic, Indian, Southern, Arctic and Cenozoic Pacific oceans are consistent, to the first order, across all three models. Larger differences between the models arise in regions where oceanic crust has been subducted, upon which they then rely on a combination of geometric (e.g. assumption of symmetrical spreading), geological, seismic and palaeomagnetic data to constrain the motion and evolution of terranes that open and close ocean basins (e.g. Liu et al., 2010, 2008; Sigloch and Mihalynuk, 2013). In these regions, the tectonic histories, even for Cenozoic times, remain the subject of ongoing research and the scenarios embedded in the global models used in this study represent one candidate amongst many competing models. For example, the extent of subduction systems within the Tethyan domain and the nature of India-Eurasia collision is still hotly debated (Hu et al., 2016; Parsons et al., 2020; van Hinsbergen et al., 2020, 2012). Similar combinations of methods have been used to propose 
alternative interpretations for circum-Pacific regions, especially for the Cretaceous and earlier times in the northwest Pacific (Domeier et al., 2017; Konstantinovskaya, 2002; Shapiro and Solov'ev, 2009; Vaes et al., 2019; Wu et al., 2016), the southwest Pacific (Hochmuth et al., 2015; Matthews et al., 2015; Schellart et al., 2006; Sutherland et al., 2020) and the northeast Pacific (Clennett et al., 2020; Sigloch and Mihalynuk, 2013). All of these regions invite competing models and alterations to existing global models and it is notable that many of the studies mentioned above have benefited from using the resources made available by previous global studies, beginning with SET12, as a starting point for detailed regional analysis.

All three models employ a relative hierarchy (Fig. 2a), in which a fully relative plate motion model is tied to an absolute plate motion model through Africa. The relative hierarchies are similar across the models because of the preserved oceanic crust. These global relative motion hierarchies are then linked to an absolute reference frame tied to the mantle, though the details of these reference frames differ between models. SET12 uses a hybrid reference frame, using a moving hotspot reference frame for 100-0 Ma (O’Neill et al., 2005) and a true-polar wander corrected palaeomagnetic reference frame for 200-100 Ma (Steinberger and Torsvik, 2008). MUL16 also adopts a hybrid absolute reference frame, but uses the moving hotspot model of Torsvik et al. (2008) instead of that of O'Neill et al. (2005) based on an assessment of the geodynamic plausibility of a range of alternative mantle reference frames by Williams et al. (2015). MUL19 departs from both SET12 and MUL16 in that is uses an absolute reference frame derived by Tetley et al. (2019). The method of Tetley et al. (2019) optimises absolute plate motions through a joint inversion involving trench motion, fitting hotspot motion tracks and net rotation to determine the motion of Africa (at the top of the relative hierarchy) that simultaneously best fits all three criteria. Despite the emphasis on mantle reference frames in these previous global models, the same relative plate motion hierarchies can also be tied to a pure paleomagnetic reference frame (e.g. Cao et al., 2019; Torsvik et al., 2008).

In this study, we rely on palaeomagnetic data as the main basis for linking absolute plate configurations continuously from the Cenozoic to the early Neoproterozoic, when tying plate configurations to the mantle is far more problematic. Nonetheless, some aspects of the more recent plate motions still rely on observations from hotspot trails - specifically, the motion of the Pacific Plate and other oceanic plates that have bordered it. During the Early Cretaceous, these plates lay within the Panthalassa ocean basin that was entirely surrounded by subduction zones, meaning that we cannot tie the motions of the oldest crust of the Pacific Plate to the continents by seafloor spreading anomalies.

Finally, with regard to Mesozoic-Cenozoic global plate models, we note that MUL19, while containing the same relative framework as SET12 and MUL16, also contains deforming plates. In MUL19, deformation 
of rifts and collisional zones are modelled explicitly, making it the first plate model to step away from the simplification of rigid plates that all other models assume. However, the reconstruction here relies on the simpler, rigid approximation used in SET12, MUL16, and other previous studies.

\subsection{Mid-late Palaeozoic plate models}

The progression of the three Palaeozoic plate models (all modelling 410-250 Ma) is slightly more nuanced than in the Mesozoic and Cenozoic because of the absence of preserved oceanic crust. DT14 is the original model and both MAT16 and YOU19 used DT14 as the basis of their Palaeozoic models and then connect to MUL16 for the Mesozoic and Cenozoic. In effect, MAT16 is the connection of DT14 (i.e. minimal changes) to MUL16, while YOU19 is an alternate version of DT14 for the Palaeozoic.

DT14 is heavily based on work by Torsvik et al. (2012) and models the amalgamation of Pangea through the collision of Laurussia and Gondwana and the evolution of the Palaeo-Tethys and opening of the MesoTethys oceans. The model has a flat hierarchy (Fig. 3a) with APWPs defined for each individual continent and each continent being tied directly to the spin axis. Domeier and Torsvik (2014) also use the PGZ method to constrain absolute palaeolongitude. Therefore, their model assumes the stable, immutable nature of the present-day LLSVPs within the mantle back to 410 Ma. DT14 is presented in both a mantle and a palaeomagnetic reference frame, with the mantle reference frame being corrected for TPW after Torsvik et al. (2014) .

MAT16 adopted the DT14 model, with minor amendments required to link it with MUL16 (see Matthews et al. (2016) for details). A key difference between the two models is that MAT16 translated the flat hierarchy of DT14 into a fully relative reference frame (i.e. converted the structure from Fig. 3a into Fig. 2a), where the motion of all plates is tied to Africa, which is then tied to an absolute plate motion model. The absolute plate motion model of MAT16 is the same as in both MUL16 (i.e. a hybrid between hotspots, slabs and palaeomagnetic data) and DT14 (i.e. absolute latitude and longitude, corrected for TPW). Thus, MAT16 also invokes the PGZ method.

YOU19, while starting from MAT16 as a base, differs much more from MAT16 than MAT16 does from DT14. This is because YOU19 uses a different base assumption, leading to notable changes in the actual plate model itself. The most important difference is that YOU19 does not assume that LLSVPs were fixed and stable back to $410 \mathrm{Ma}$. They abandon the PGZ method for constraining palaeolongitude and thus argue that they can better accommodate geological and kinematic (plate speed and trench migration) criteria more 
strongly than either DT14 or MAT16. The two key changes that YOU19 implemented (relative to DT14 and MAT16) are shifting Laurussia in latitude and longitude to be closer to its position in Pangea against Gondwana, thus removing a dextral motion between the Patagonian margin of South America and Laurussia (e.g. Fig. 2c), and removing easterly drift of South China during the Carboniferous-Permian. The implementation of both in DT14 (and then in MAT16) is a consequence of the PGZ method, since the longitudinal position of Laurussia and South China is based on fitting preserved eruptions to the edges of LLSVPs (Domeier and Torsvik, 2014). YOU19 argue that the interpretations of DT14 introduce unrealistic kinematic scenarios: $8000 \mathrm{~km}$ of relative dextral motion between Laurussia and the Patagonian margin of

584 Gondwana (e.g. Fig 2c) at a relative plate velocity of $30 \mathrm{~cm} / \mathrm{a}$ and South China moving at plate speeds of $58540 \mathrm{~cm} / \mathrm{a}$ between 260 and $250 \mathrm{Ma}$ in MAT16 (Young et al., 2019). The dextral motion between Gondwana 586 and Laurussia of DT14 and MAT16 that that YOU19 removed is not a transition from the Pangea B to 587 Pangea A configuration, which is explicitly defined as dextral motion after Pangea formed (Domeier et al., 588 2012). Rather, all three models adopt a Pangea A configuration and include some component of dextral motion between Laurussia and Columbian-Mexican margin of Gondwana in the Devonian. However, the position of Laurussia in YOU19 is unsupported palaeomagnetically by $\sim 30^{\circ}$ (Section 4.2 and 5.1), which is problematic as there is an abundance of data from both Laurentia and Baltica to constrain its position at

Recently, Wu et al. (2020) have also proposed an integrated geological and palaeomagnetic model for the amalgamation of Pangea. Their study used a different selection of palaeomagnetic data (all three mid-late Palaeozoic full-plate models discussed here used the compilation of Torsvik et al. (2012) as a base) and a new method of APWP generation that weighted poles based on their quality and uncertainty. The model of $\mathrm{Wu}$ et al. (2020) also suggested that the formation of Pangea was originally initiated by collision between Laurussia and a promontory of Gondwana consisting of the Variscan Massifs at ca. 400 Ma. In their model,

600 the promontory formed by the scissor-like opening of the Palaeotethys Ocean off the northern margin of 601 Gondwana. In principle this model would be very compatible with the one we present here, however as the 602 model of Wu et al. (2020) is currently only palaeogeographic, we do not consider it as an option for merging 603 in this study.

604

605

606 YOU19, like MAT16, uses a relative plate hierarchy with Africa as the root of the hierarchy. Africa is connected to an absolute plate motion model using the Torsvik and Van der Voo (2002) APWP for the 608 has no absolute palaeolongitude control, YOU19 does not constrain or correct for TPW in the Palaeozoic 609 and is therefore presented in a purely palaeomagnetic reference frame. 


\subsection{Early Palaeozoic plate models}

613 Two separate models exist for part of the Early Palaeozoic between 500 and $410 \mathrm{Ma}$. Each of these two

614 models focus on a separate area of the Earth at the time. DOM16 focuses on the evolution of the Iapetus

615 and Rheic oceans and the amalgamation of Laurussia (Baltica, Laurentia and Avalonia). DOM18 models

616 the evolution of Siberia, Gondwana, the terranes that now make up the Central Asian Orogenic Belt and

617 the Chinese cratons (Tarim, North and South China). While each model focuses on a different area, the

618 overarching assumptions and framework of both models are identical. Both models follow the approach of

619 DT14, possessing a flat hierarchy with APWPs being defined for most continents, such that they all move 620 independently from each other. The model extends the assumptions of the PGZ method back to 500 Ma, 621 using the location of LIPs and kimberlites to constrain absolute palaeolongitude. Both models therefore 622 have a TPW correction, and are presented in a mantle and palaeomagnetic reference frame.

Only one full plate model exists for the Neoproterozoic (MER17, Merdith et al., 2017a). MER17 is based on Li et al. $(2013,2008)$ and models the evolution of Rodinia; it's breakup and the amalgamation of Gondwana (1000-520 Ma). There are, however, a number of important considerations that differentiate MER17 from Phanerozoic full-plate models. Firstly, MER17 used a hybrid plate rotation hierarchy, defining two separate nodes that move independently from each other using palaeomagnetic data tied directly to the spin axis (India as one and Laurentia, as the centre of Rodinia, as the second) (Fig. 5a, b). In this model, India and Laurentia both act as separate roots that then constrain a series of relative plate rotations that collectively describe the rest of the world. Secondly, the continental drift model of Li et al.

634 (2013) invokes the orthoversion model of determining palaeolongitude, where they fix the $I_{\min }$ of Rodinia 635 to be at $100^{\circ} \mathrm{E}$. As MER17 adopted these rotations as their base, there is an element of the orthoversion 636 model preserved between models. However, MER17 also drastically changed the configuration of Rodinia, 637 as well as the timing of breakup, compared to Li et al. (2013), relative rotations within the Laurentian (i.e. 638 Rodinian) node and absolute rotation of Laurentia itself in order to fit geological and kinematic constraints.

639 They did not recalculate TPW and the $I_{\min }$ of Rodinia, thus MER17 does not have a strict absolute 640 palaeolongitude control. Finally, there is no correction for TPW in MER17 and no mantle reference frame; 641 the model is presented purely in a palaeomagnetic reference frame. 


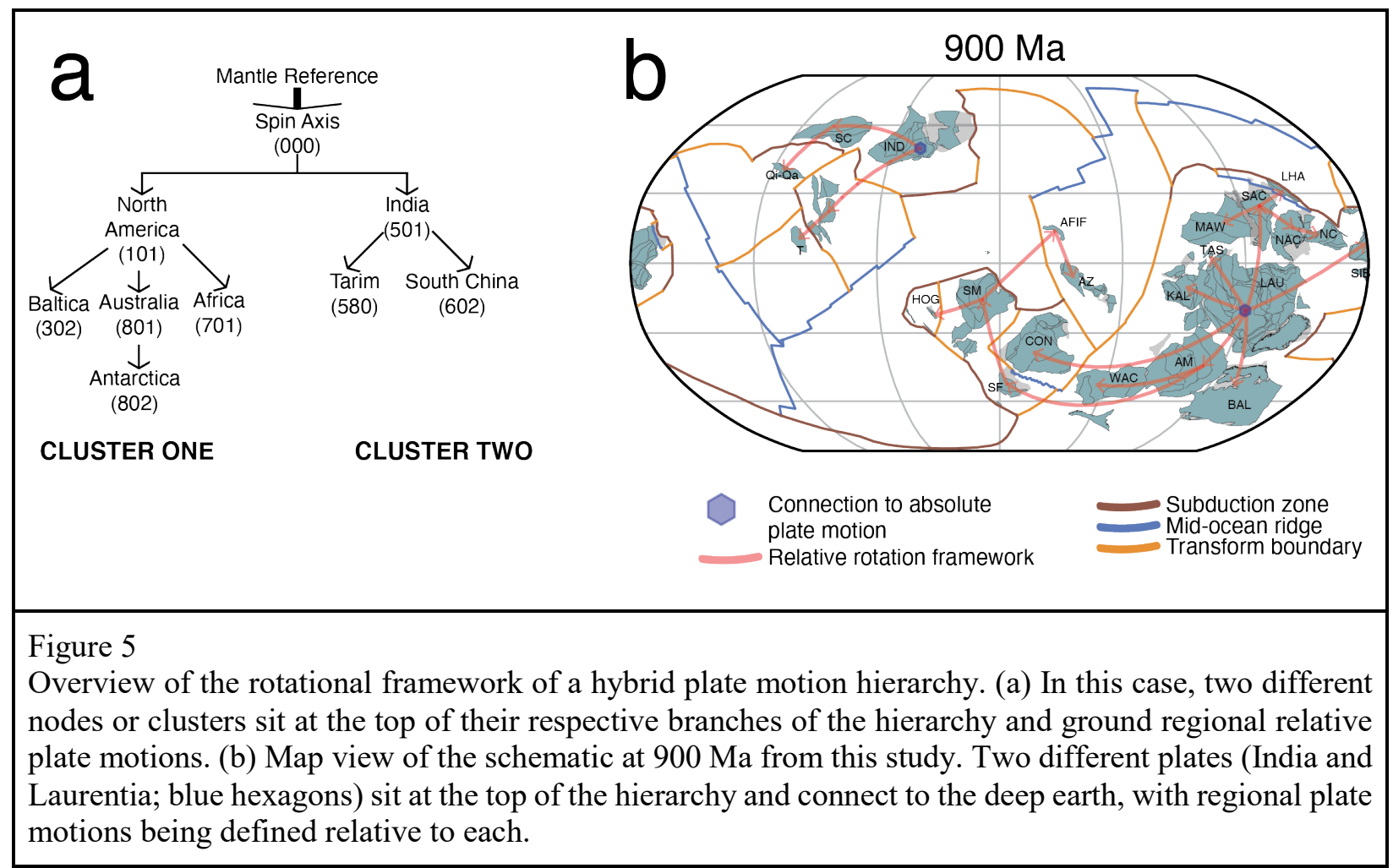

\subsection{Model selection}

646 In order to produce a coherent global model, we must select from the models described above that best

647 align with our goals: (i) open the Neoproterozoic and Cambrian up for quantitative tectonic analysis; (ii)

648 create a framework that can support local or regional studies for the Neoproterozoic and (iii) a foundation

649 for future studies looking at long timescale (>10-100 Ma) trends in either tectonics or geodynamics.

As our aim is to produce a model back to $1 \mathrm{Ga}$, three choices are already made for us because they are the only models that exist for those time periods: MER17 for 1000-520 Ma, and DOM16 and DOM18 for 500$410 \mathrm{Ma}$. For the remaining time period, MAT16 (an extension of DT14) and YOU19 are viable options.

654 Both models link to the MUL16 model and choosing between them requires considering the reconstruction 655 framework (e.g. hierarchy, reference frame) of our model with respect to our intent. To satisfy our goals, 656 we need a model in a palaeomagnetic reference frame. We acknowledge the value and potential in exploring 657 hypotheses for constraining palaeolongitude. However, since tectonic reconstruction models, such as the 658 one we are presenting here, are a required starting point for exploring the long-term evolution of mantle, 659 we have kept the model conservative by not assuming the fixity of LLSVPs or that TPW dictates 660 supercontinent position. Therefore, we elect to leave palaeolongitude unconstrained by either PGZ or 661 orthoversion methods. Thus, we selected the YOU19 model, as it has removed the absolute palaeolongitude 
662

663

664

665

666

667

668

669

670

671

672

673

674

675

676

677

678

679

680

681

682

683

684

685

686

687

688

689

690

691

692

693

694

695

controls adopted in MAT16. We stress that our approach is deliberately conservative and requires the fewest a priori assumptions, but anticipate that future developments will see improvements in the model presented and that a comparison of several end member models would be useful for evaluating the long-term connection between lithosphere and mantle. One promising way forward could be to optimise tectonic parameters, such as subduction zone migration and plate velocity in the manner of Tetley et al. (2019) to define a mantle reference frame. The model we present is an essential precursor for such techniques. Our model is constructed with a palaeomagnetic reference frame, that is, even at younger times, there is no mantle reference frame. For studies needing such a reference frame, which only exists since the Cretaceous, we suggest people use either SET12, MUL16 or MUL19.

\subsubsection{Our approach to plate modelling}

Here we outline our approach to merging individual plate models into a coherent global plate model spanning the past $1 \mathrm{Ga}$. As detailed above, our goal is a geologically constrained model within a palaeomagnetic framework. In addition to reconstructing plate motions, we also model plate boundaries, which requires us to also focus on the relative motion between plates. The evolution of plate boundaries is commonly preserved in the geological record such as passive margins marking divergent boundaries and magmatic arcs recording convergence. Palaeomagnetic data, although providing a quantitative absolute constraint on the position of a craton, have varying uncertainty that allow some manipulation and flexibility. For example, continental drift models (and APWPs) typically fit the data as tightly as possible. However recent studies have analysed the effect of exploring both the temporal (i.e. age constraints) and statistical uncertainty to create alternative APWPs (Tetley et al., 2019; Wu et al., 2020). Given this, we use a hybrid approach that adopts parts of both the flat, palaeomagnetic hierarchy traditionally used for Precambrian reconstructions and the relative framework used in more recent times.

Using this approach, our model has multiple clusters of related cratonic elements moving together (Fig. 5a). Whether a specific cratonic element moves relative to another is dependent on their geological relationship. For example, if they are separated by an incipient ocean basin as indicated by geological data then we suggest that it is easiest for them to be moving relative to each other (within the bounds of whatever available palaeomagnetic data), because the relative relationship of divergence (expressed as a mid-ocean ridge) is preserved. The hierarchy is defined by geological precedence, where terranes move relative to blocks, blocks move relative to cratons and cratons move relative to 'supercontinents'. In this manner, generally (but not necessarily exclusively), crust with more preserved data should always be placed above crust with less preserved data in the hierarchy, because we have more confidence in the geological evolution 
696 (and also likely palaeomagnetic constraints) from these continents. Alternatively, if continents are separated

697 by a large ocean basin, we form a new cluster. This cluster-approach has an added benefit in the more

698 uncertain Neoproterozoic, as it means that we can simply introduce a new cluster for Rodinia, which has

699 Laurentia as the root of the relative hierarchy, instead of maintaining Africa or the Congo craton at the top

700 of the cluster (which are the roots of Pangea and Gondwana, respectively) and can also introduce a cluster

701 for India and South China which, in our interpretation, move separately to Rodinia on the other side of the 702 globe.

A full-plate reconstruction models both continents (palaeomagnetic data) and plate boundaries (geological data). Therefore, we use both data simultaneously to iterate towards a solution. Palaeomagnetic data are used initially to build a continental drift framework (e.g. (Li et al., 2013, 2008). If palaeomagnetic data are abundant and of high quality, then either an APWP or GAPWaP are constructed, which we do for the Phanerozoic. We then introduce geological data in the form of plate boundaries (e.g. compilation of rifts and arcs (Merdith et al., 2017b)) and use the compilation to manipulate the model in a manner that still fits the palaeomagnetic data, but also accommodates geological data. Structural and metamorphic constraints are used here principally to infer (where possible): (i) polarity of subduction, (ii) collision timing and (iii)

717 more finely model the plate boundary network. Other pieces of geological data, such as faunal provinces

718 (e.g. Burrett et al., 1990), isotopic signatures (e.g. Collins et al., 2011) and detrital zircons (e.g Cawood et

719 al., 1999) are used here to assist with connecting disparate terranes to larger blocks that they share affinity

720 with or to infer the presence of a plate boundary not directly preserved in the geological record (such as by

721 a diverging fossil record).

723 Because our model contains geological data in the form of plate boundaries, we are particularly interested 724 in ensuring the forwards and backwards compatibility of any decision made around geological data, 725 especially for terranes or blocks that have limited palaeomagnetic data. For example, if the data support 726 two or three interpretations in the early Neoproterozoic, but only one of those is consistent with an 727 Ediacaran (or younger position), then we consider that position more reliable than the other two. However, 728 we argue that this logic also works in reverse; if a number of positions are deemed viable in the Ediacaran 729 for a terrane based on the data available, but only one of those also fits what data are available in the early 
Neoproterozoic, then we will use the older data to force an interpretation of the younger data (e.g. Evans, 2009). This argument is highlighted by the concept of 'world uncertainty' (the percentage of total crust (oceanic and continental) on the earth at any one time that is also preserved at present-day) of Torsvik et al. (2010b). Because time is asymmetrical, this means that the level of confidence we have at present-day is $100 \%$, but decreases linearly back in time to $\sim 70 \%$ at $200 \mathrm{Ma}$ (i.e. $70 \%$ of all crust at $200 \mathrm{Ma}$ is no longer preserved). At $400 \mathrm{Ma}$, the world certainty is $\sim 73 \%$ (Domeier and Torsvik, 2017), and using estimates of continental crustal volumes, at $600 \mathrm{Ma}$ it is between 75 and 80\% (Cawood et al., 2013a). Therefore, for the Mesozoic and Cenozoic, data from younger times are much more compelling to force interpretations of older data because of how much more confident one can be in the last $20 \mathrm{Ma}$. Comparably, the difference in this measure of uncertainty is much smaller between the Neoproterozoic and Cambrian, thus we suggest that models in this time period should simultaneously use older and younger data to iterate towards a solution.

\section{Palaeomagnetic Data}

A major problem in comparing the Phanerozoic models is that they all use different rotational frameworks, including reference trees (i.e. flat vs hierarchical) and different absolute reference frames. In order to properly synthesise the DOM16, DOM18 and YOU19 models into a single reconstruction, we first need to lay a coherent groundwork in defining an absolute plate motion model for the largest continents during this time in order to merge the individual models. To do this, we first derive a new APWP for Gondwana (540$320 \mathrm{Ma}$ ) and GAPWaP for Pangea (320-0 Ma) using the palaeomagnetic compilation of Torsvik et al. (2012) to provide an absolute palaeomagnetic reference frame for 540 to $0 \mathrm{Ma}$. We also apply the GAPWaP to the MUL16 portion (i.e. the Mesozoic and Cenozoic) of the YOU19 model. We do this to ensure compatibility between the Cenozoic and Palaeozoic, and also because our goals for this model are broad scale ( $>10-100 \mathrm{Ma}$ ) trends, mostly focussed on the Neoproterozoic. The method we follow to calculate our APWP and GAPWaP is outlined below. For the Neoproterozoic, and non-Gondwana constituents of the Palaeozoic, we use the compilations of palaeomagnetic data as presented in MER17, DOM16 and DOM18, along with some other additions. Palaeomagnetically derived alterations to the models are also discussed below.

\subsection{APWP and GAPWaP construction}

The absolute reference frames for Gondwana (540-320 Ma) and Pangea (320-0 Ma) used in this study are derived using the method and velocity-optimised global palaeomagnetic data of Tetley (2018). APWPs are 
routinely constructed using poles assigned averaged or nominal ages, which particularly for older times, where palaeomagnetic constraint becomes increasingly limited, contribute to spurious apparent polar wander behaviours. This method directly evaluate individual palaeomagnetic pole age and associated uncertainty in combination with calculated pole A95 latitude and longitude uncertainties to derive optimised APWPs that minimise predicted plate velocities and plate velocity gradients (instantaneous accelerations). The resulting rate of apparent polar wander in optimised APWPs was reduced globally by an average of $56 \%$ by comparison to existing APWPs, resulting in predicted Phanerozoic plate motions displaying greater kinematic consistency with present-day plate motion behaviours.

Optimised APWPs were produced for the 15 major continental blocks of Amazonia, Australia, Colorado, East Antarctica, Greenland, India-Pakistan, Madagascar, Meseta, North America, Northeast Africa, Northwest Africa, Panama, Patagonia, Somalia, and Stable Europe. Applying the method as described in Torsvik et al. $(2012,2008)$ and the data provided in Torsvik et a. (2012), optimised continental pole data from all 15 continents were rotated from their individual source coordinate frames into a consistent South African coordinate frame using the rotation model from this study. Now in a consistent coordinate frame, a GAPWaP for Pangea was produced using all poles aged 320-0 Ma (due to the collision of Laurussia and Gondwana during the Late Carboniferous), with a second GAPWaP produced using poles aged 540-320 Ma associated with Gondwana (South America, Africa, India, Antarctica and Australia) only. For both GAPWaP reference frames, the GMAP software was used (Torsvik et al., 2012, 2008; Torsvik and Smethurst, 1989), applying a running mean method using a window size of 20 Ma and a step size of 10 Ma.

\subsection{Palaeomagnetic compilation}

A compilation of palaeomagnetic data was used to constrain the position of all continental blocks during the Neoproterozoic and for non-Gondwanan continental blocks during the early and middle Palaeozoic. The Neoproterozoic data are presented in Table 2 and a GPlates compatible file of the data is also presented in the Supplementary Material. Figure $6 \mathrm{a}-\mathrm{c}$ shows the great circle misfit of our model to the selected poles. As the majority of the data have already been used in the MER17, DOM16 and DOM18 reconstructions, we point readers to those publications for in-depth discussion of the data. Here, we discuss two alterations to the base models that we implemented based on palaeomagnetic data: Tarim at ca. $700 \mathrm{Ma}$ and Laurussia at ca. $420-400$ Ma.

The MER17 model omitted Tarim prior to 700 Ma due to its pre-700 Ma palaeomagnetic data nullifying the position that placed it outboard of Australia. We rectify this and include a robust, time-sensitive 
geological argument for its position against India-South China during the Tonian (1000-720 Ma) and Cryogenian (720-635 Ma) (Section 5.4.2). The rationale for placing Tarim in this position is to allow for a significant $180^{\circ}$ rotation required by paleomagnetic data. Two well-dated and high-quality poles; the 760720 Ma Qiaoenbrak Formation (Wen et al., 2013) and the 770-717 Ma Baiyisi Volcanics (Huang et al., 2005) are internally consistent and require Tarim to be inverted $180^{\circ}$ from its present-day position (i.e. northern margin facing south). A third pole, assumed to be pre $700 \mathrm{Ma}$, from the Aksu Dykes (Chen et al., 2004) is rejected for poor age constraints and the possibility of remagnetisation (Wen et al., 2017). Comparably, three younger poles: the 635-550 Ma Sugetbrak Formation (Zhan et al., 2007), the ca. 635 Ma Tereeken Cap Carbonate (Zhao et al., 2014) and the 621-609 Ma Zhamoketi Andesite (Zhao et al., 2014) are all consistent with each other and indicate that Tarim was in its present-day orientation. A recent pole by Wen et al. (2017) from the Lower Sugetbrak formation (640-615 Ma) stands in conflict with these three poles, suggesting a $\sim 50^{\circ}$ rotational difference in the orientation of Tarim, while maintaining the same palaeolatitude. Wen et al. (2017) dismiss the three earlier poles due to similarity to Silurian-Devonian poles

Successfully fitting the two older poles with either the three younger poles or the single pole of Wen et al. (2017) is not possible in a model in which Tarim is surrounded by continental lithosphere for the Neoproterozoic or in a scenario where Tarim is attached to the north-western or northern margin of Australia or the northern margin of India (e.g. instead of South China). An accommodation of the data can be obtained by placing Tarim in a 'Missing-Link' position (between Australia and Laurentia) with breakout and rotation of Tarim from ca. $700 \mathrm{Ma}$; as argued by Wen et al. $(2018,2017)$. However, beyond the kinematic issues with Missing-Link style models (Merdith et al., 2017b), it is difficult to account for the formation of the $760 \mathrm{Ma}$ Aksu Blueschist if Tarim was located in the centre of an assembled Rodinia (see comment by Song and Li (2019) and reply by Wen et al. (2019)). In the present model, we use the pole of Wen et al. (2017) due to its greater reliability, though our model could easily be adapted to fit the other three poles if necessary (Section 5.4.2.). We also note that although we argue that India-South China were separate from the rest of Rodinia, our preferred Neoproterozoic position for Tarim is also compatible with models in which India-South China formed part of Rodinia (e.g. Cawood et al., 2013b).

In the YOU19 model, Laurussia was moved $\sim 30^{\circ}$ further north in latitude relative to its position in DT14 and MAT16 (Section 3.3). The consequence of this decision by YOU19 is that Laurussia is not in a 829 palaeomagnetically constrained position in the late Silurian and early Devonian. For this model, in addition 830 to the compilation of palaeomagnetic data in Torsvik et al. (2012), we also used palaeomagnetic data from 831 mainland Baltica (Table 2) to constrain the late Silurian to early Devonian position of Laurussia. We 
832 implement these alterations to produce a coherent motion of Laurentia (later Laurussia) and Gondwana that 833 fits palaeomagnetic data, while also ensuring that the relative motion between Gondwana and Laurussia is 834 convergent, rather than dextral transform (e.g. Fig. 2c).

835 

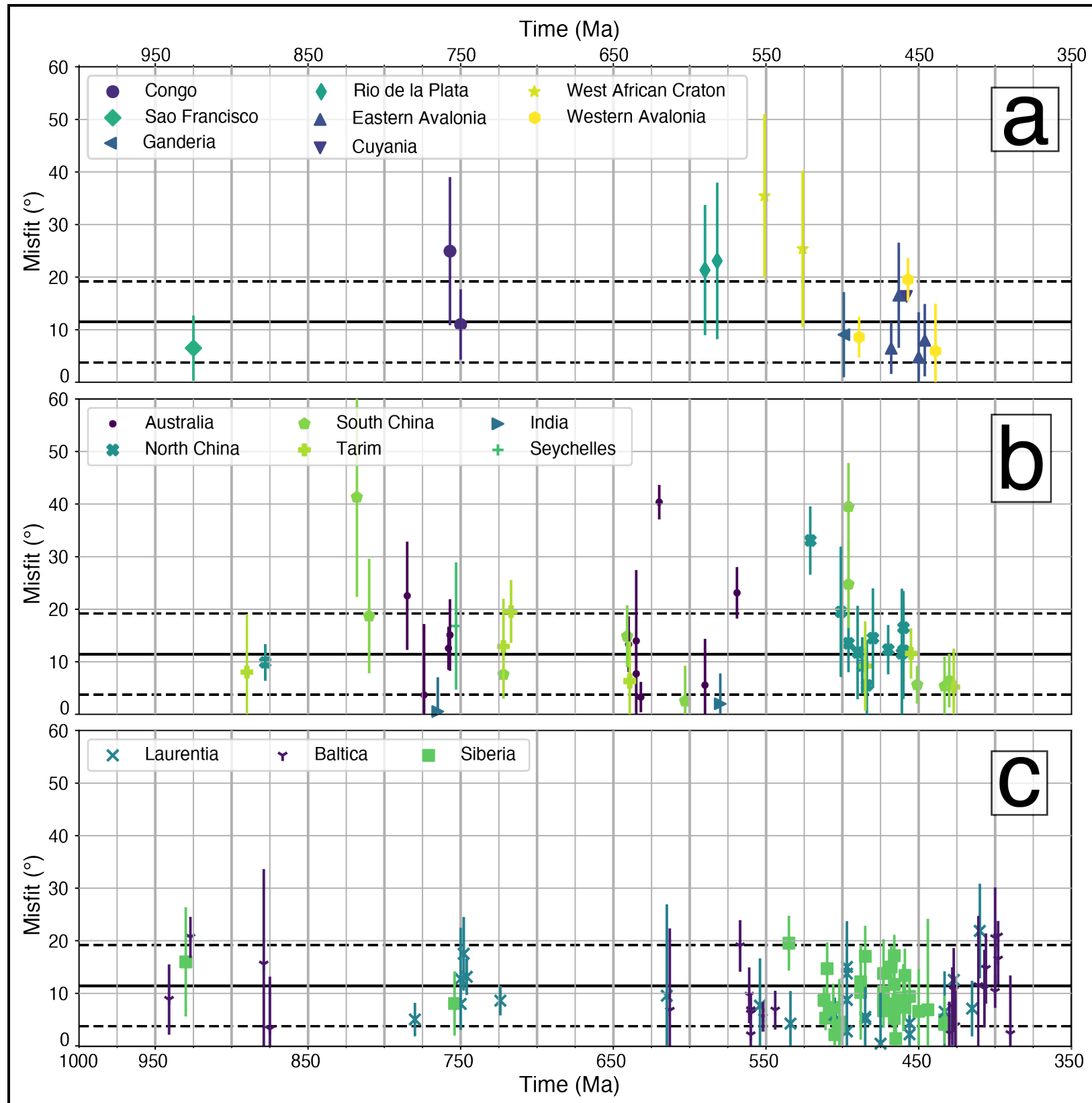

Figure 6

Summary of the fit of palaeomagnetic data to our model for 1000 to $400 \mathrm{Ma}$ (omitting poles used to construct the Gondwana APWP). Misfit is the minimum great circle distance (in degrees) within the valid time range between the palaeomagnetic pole and the geographic north pole. The error bar on each point is the pole $95 \%$ confidence limit (A95). Solid line is the mean misfit of all poles, with the dashed lines representing the standard deviation of the mean. Poles marked as 'not used' or 'inclination only' in Table 1 are not included in this figure. (a) Poles from the constituent cratons of western Gondwana and the Avalonian terranes; (b) poles from the constituent cratons of eastern Gondwana and present-day Asia, and; (c) poles from Laurussia and Siberia. 
840 We describe the alterations made to individual models separately for clarity, however, we stress that no 841 single model was treated in isolation. Each alteration, whether during the Tonian or Devonian, was

842 evaluated both forwards and backwards in time in order to ensure continuity with both older and younger 843 geological and/or palaeomagnetic evidence. We begin our discussion with the alterations made to YOU19, 844 followed by alterations to DOM16, DOM18 and MER17. The alterations to DOM16 and DOM18 are 845 discussed together, as the two models essentially form a single global model between 500 and $410 \mathrm{Ma}$. The 846 most significant changes, and the focus of much of the discussion, occurred in MER17. This is because, 847 firstly, connecting this model with younger models in order to validate Neoproterozoic tectonic-geography 848 is a primary goal of this study, and secondly, because many of the alterations are completely new and have 849 never been incorporated into a plate model before. Figure $7 \mathrm{a}-\mathrm{b}$ displays a latitudinal overview of the major 850 and minor cratons in our model, with a comparison to the DOM-MAT models for the Phanerozoic, and the 851 model of Li et al. $(2013,2008)$ for the Neoproterozoic. Figures 8, 9 and 10 show overviews of our 852 reconstruction at $1000 \mathrm{Ma}, 500 \mathrm{Ma}$ and present-day with relevant terranes and blocks highlighted. 


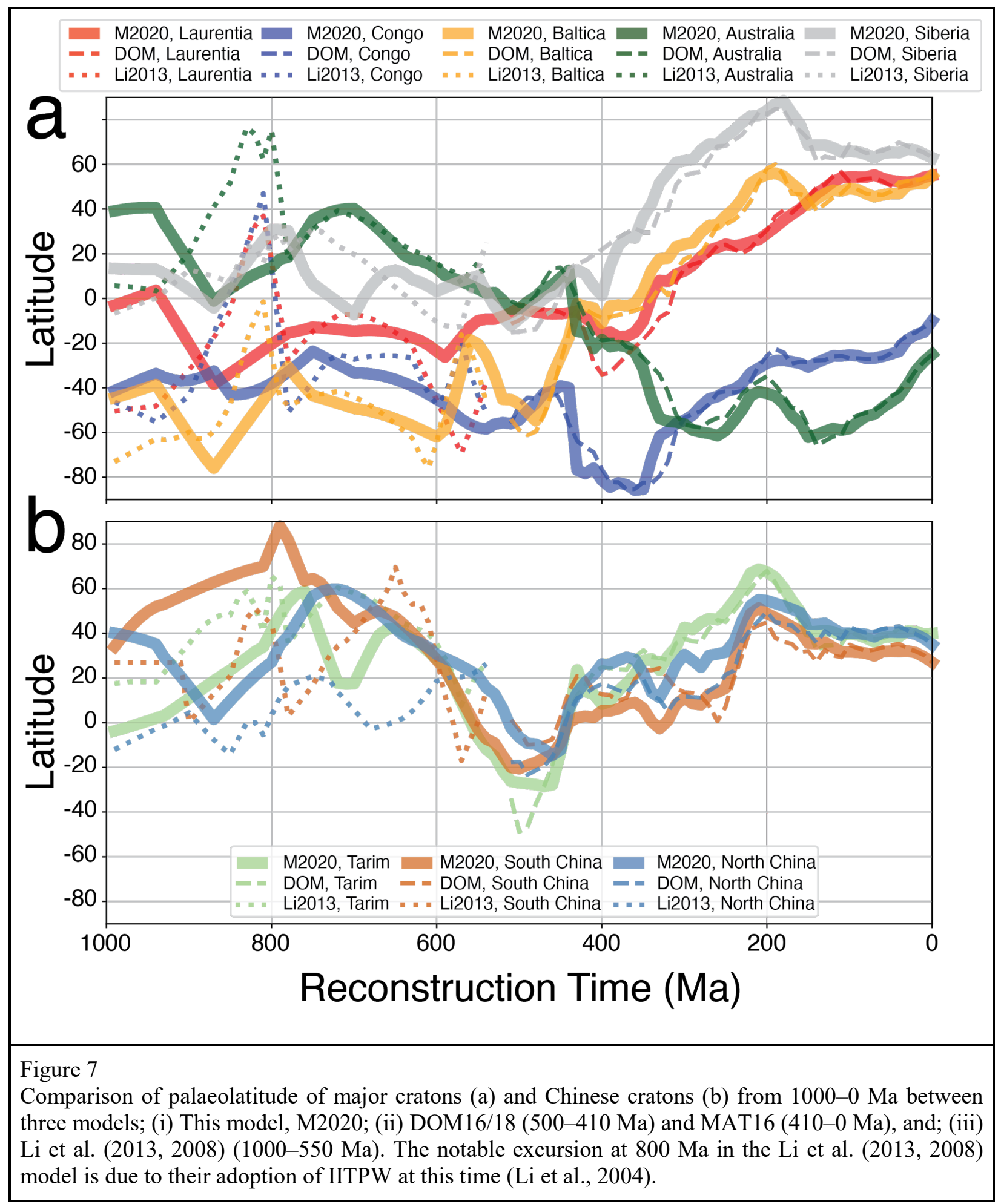




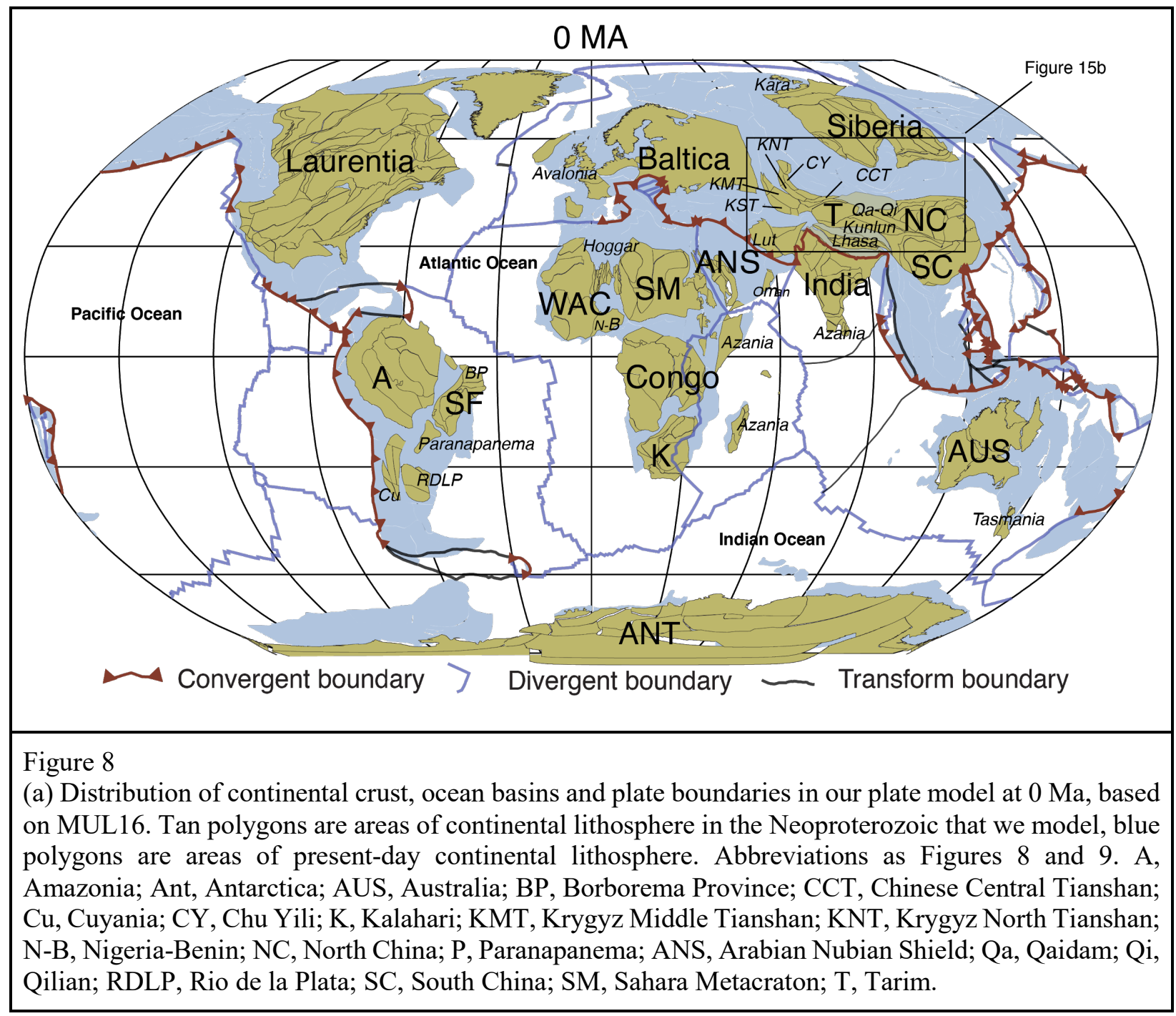




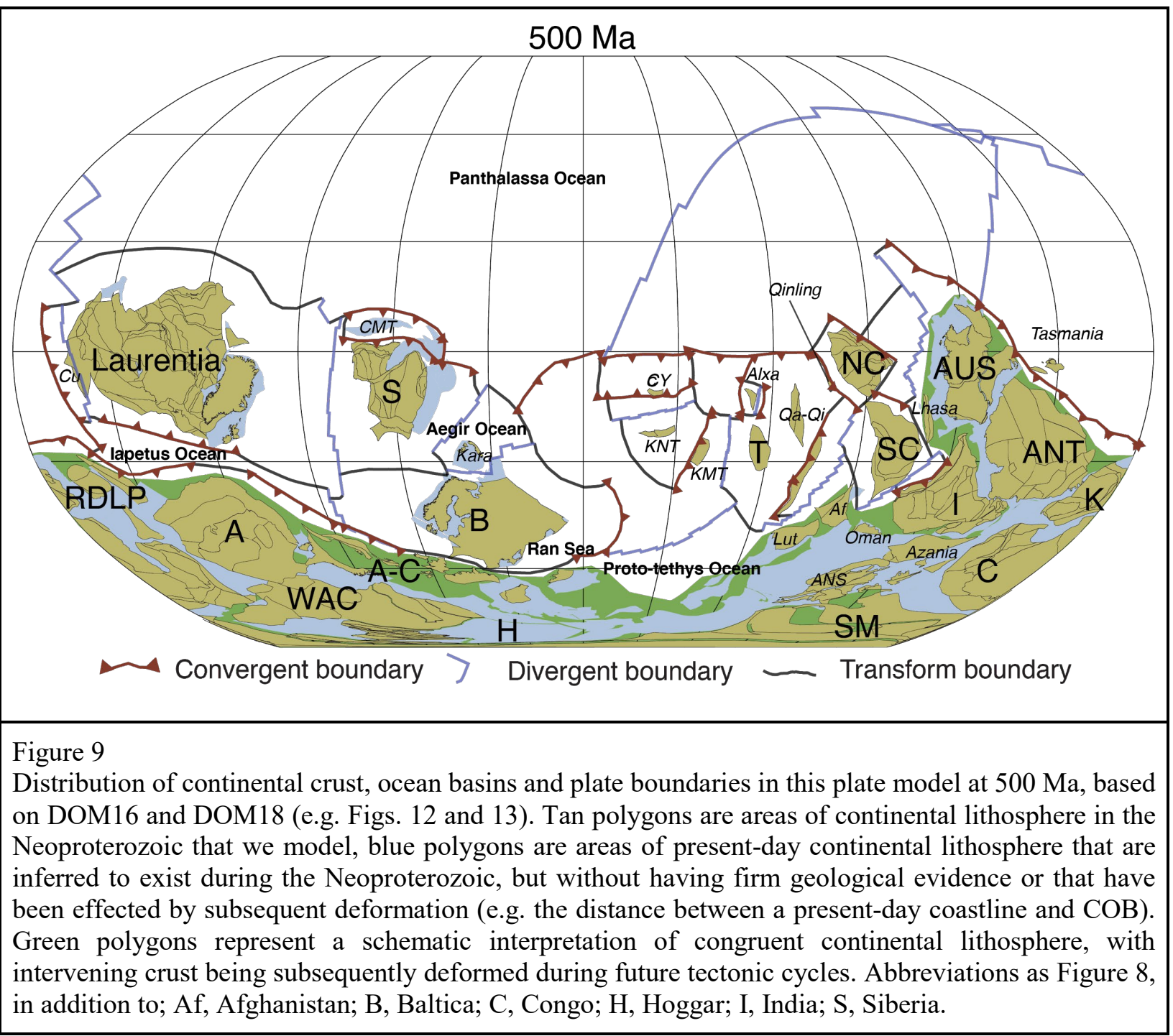




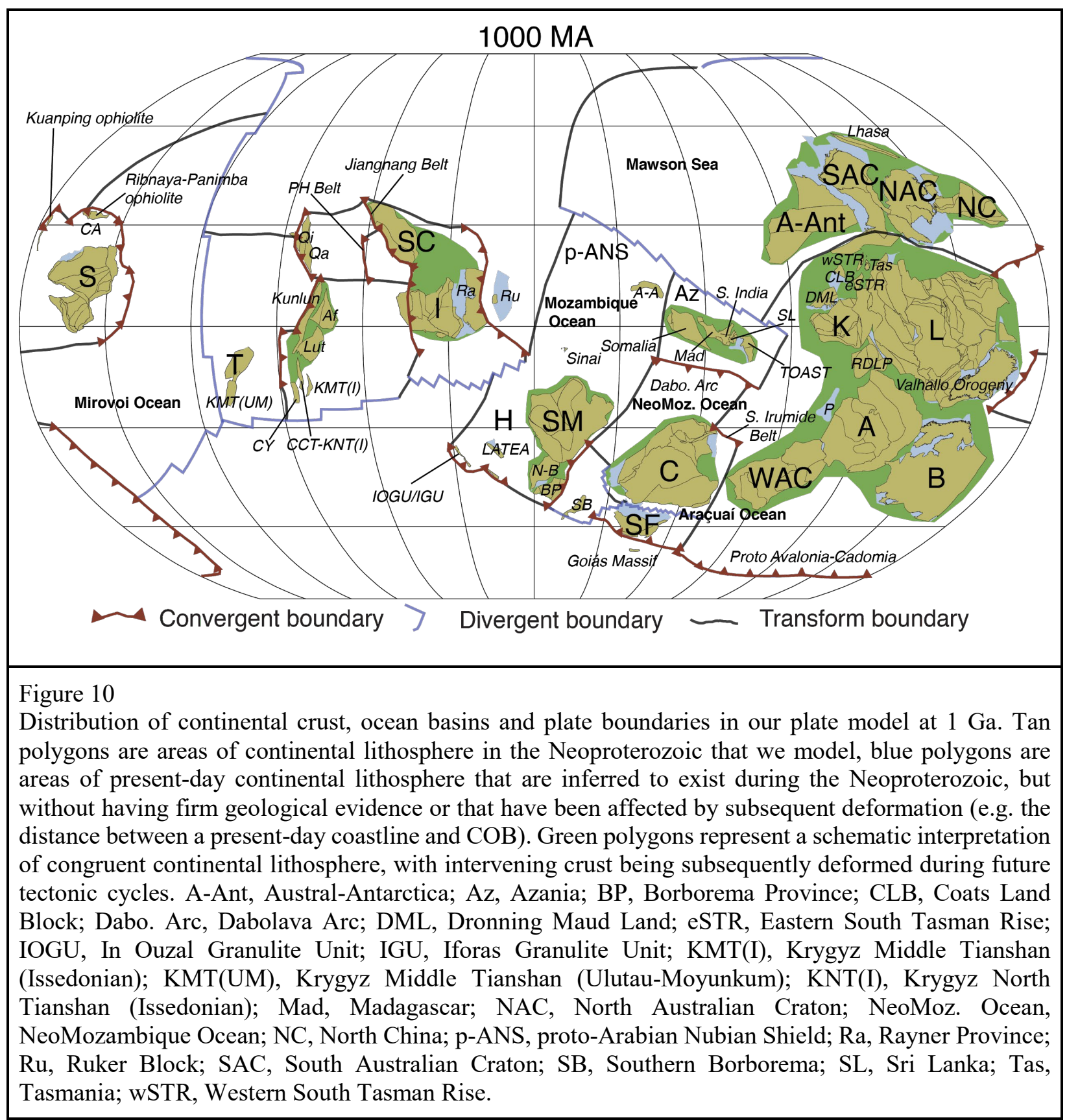

\subsection{YOU19}

862 The primary change we made to YOU19 was the implementation of a new APWP for Gondwana from 540

863 to $320 \mathrm{Ma}$ and a GAPWaP for 320 to $0 \mathrm{Ma}$ (Tetley, 2018). We also adjusted the position of Laurussia

864 during the Devonian in order to better fit palaeomagnetic data and implemented an alternative position for

865 Lhasa (against northwest Australia) that we consider to be more consistent with geological data in the

866 Neoproterozoic (Section 5.4.1). 
868 In the YOU19 reconstruction, Laurussia is rotated roughly $40^{\circ}$ counter-clockwise compared to the DT14

869 and MAT16 reconstructions (Fig. 11). While these changes improved the global kinematic integrity of the

870 model (Young et al., 2019), the position of Baltica in this configuration conflicts with palaeomagnetic data,

871 which indicates it lay at more southerly latitudes (Torsvik et al., 2012). We used the compilation of Torsvik

872 et al. (2012) as a base, however, as many of the poles in that dataset for the late Silurian to early Devonian

873 were taken from the British Isles (c.f. Jeleńska et al., 2015), we supplement it with some data from cratonic,

874 continental Europe (Table 2, S. Pisarevsky pers. comm.). We modify the position of Laurussia from that 875 used in YOU19 such that it fits the cluster of poles at this time (Fig. 11b). This modification places it in a

876 similar latitudinal position to DT14 and MAT16 (e.g. Fig. 7a), however, we shift it further east relative to

877 DT14, so that it is closer to its final position in Pangea. This position then satisfies the kinematic and

878 structural issues outlined in YOU19, while maintaining Baltica and Laurussia at a palaeolatitude permitted

879 by palaeomagnetic data. 


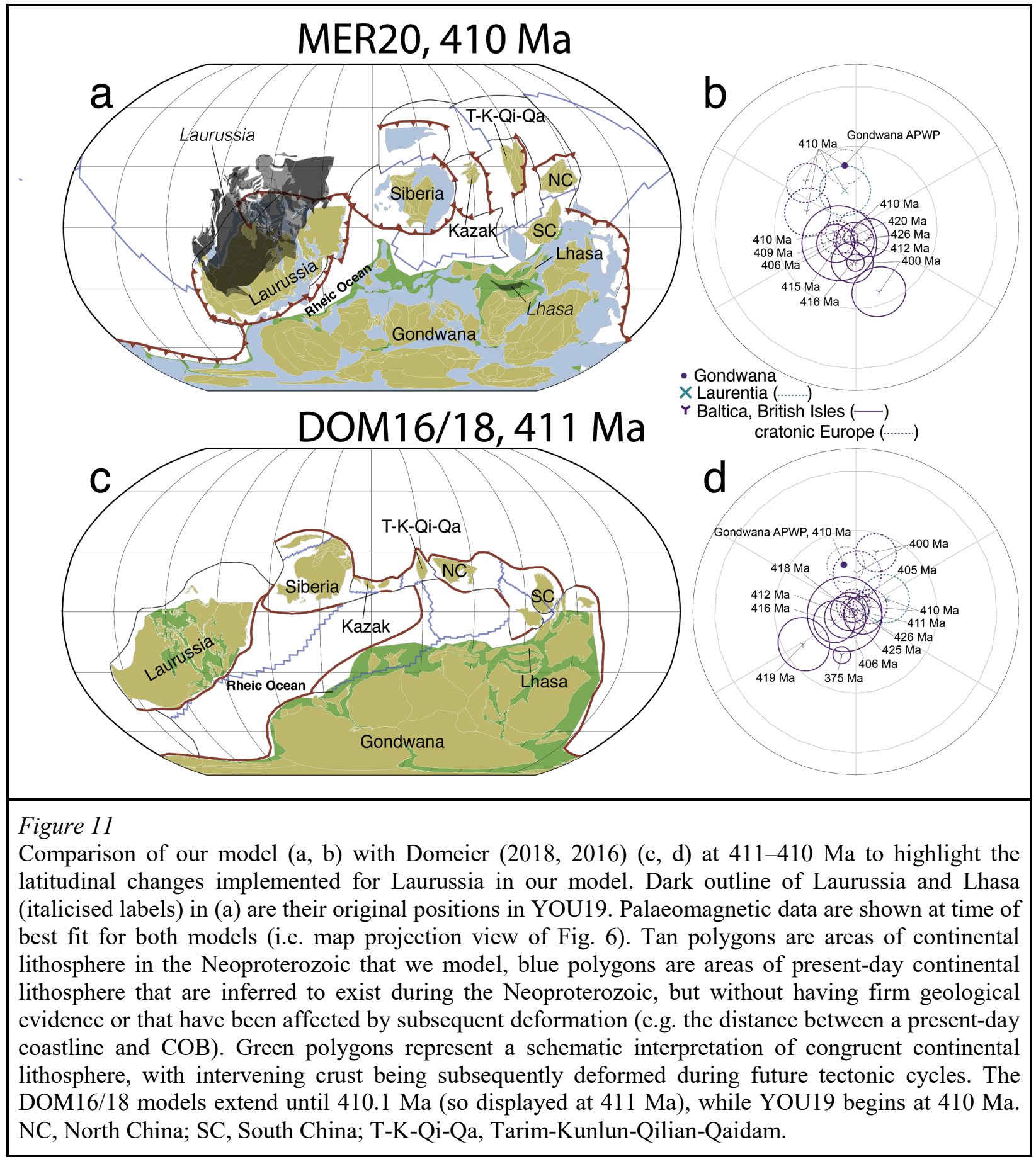

883 The Lhasa block, currently preserved in the Tibetan Plateau between India and Tarim, is an E-W elongated 884 block consisting of Precambrian metamorphic basement, overlain by predominantly Palaeozoic 885 sedimentary rocks and Mesozoic and Cenozoic volcanic assemblages (Yin and Harrison, 2000; Zhu et al., 886 2013). The Precambrian basement is established only in the southern and central terranes of Lhasa (Zhu et 
al., 2013) and in the Amdo micro-block that is preserved in the Mesozoic northern Lhasa terrane (e.g. Fig. 10b). Lhasa is typically placed outboard of the Tethyan Himalayan terranes, off the northern margin of India within Gondwana (e.g. Domeier and Torsvik, 2014). However, an alternative position outboard of northwest Australia is also supported; a scenario consistent with tectonic affinities interpreted from zircon age spectra and Hf isotopic signatures (Burrett et al., 2014; Zhu et al., 2011). We find a position off northwest Australia more consistent with the Neoproterozoic geological record of Lhasa (Section 5.4.1) that preserves magmatism interpreted to represent the existence of a subduction zone and back-arc (Guynn et al., 2012; Hu et al., 2018), which would otherwise be impossible to produce if it was land-locked between India and South China. We therefore alter the position of Lhasa from YOU19 to outboard of NW Australia. For simplicity, we infer Lhasa's motion to follow the drift of the Cimmerian terranes, but recognise that the palaeolatitudes need further refinement in the Jurassic and Cretaceous following syntheses such as Li et al. $(2017,2016)$ and others.

\subsection{DOM16 and DOM18}

We sought to preserve, as closely as possible, the palaeolatitudes and the tectonic interpretations (i.e. history of collisions, rifting, subduction and ocean basin evolution) of the DOM16 and DOM18 reconstructions. The position of Gondwana (both in Early Palaeozoic and the older times covered by MER17) has been adjusted to inherit the Gondwana position at 410 Ma from the new Gondwana APWP path described above. Relative rotations of smaller blocks to Gondwana were calculated from DOM16/18 and translated into the new position of Gondwana. Further adjustments to all continental polygons have been implemented to smooth the transition from the late Palaeozoic configurations inherited from the adjusted YOU19 model (adj-YOU19). The following sections detail adjustments to the DOM16/18 models made for the late Cambrian-Devonian.

Figure 11 shows a direct comparison between the DOM16/18 reconstructions and our adj-YOU19 model at 411/410 Ma. The primary differences between the models are longitudinal, as our adj-YOU19 model shifts Laurussia, Siberia, Kazak, Tairm and North China $\sim 30^{\circ}$ longitudinally to the east compared to DOM16/18 (as well as when compared to DT14 and MAT16, which link closely to DOM16/18), in order to better model the amalgamation of Laurussia and Gondwana. This results in a far narrower Rheic Ocean at $410 \mathrm{Ma}$ in our model and a much simpler collision between Laurussia and Gondwana (e.g. Wu et al., 2020; Young et al., 2019). This change is discussed further in context in the following section. 
The motions of Baltica, Laurentia, and Siberia are tied directly to the spin axis through their own individual palaeomagnetic reference frame, in contrast to the younger parts of the reconstruction where we retain the hierarchy inherited from YOU19. For minor cratons (Tarim, North China, South China) and smaller blocks (e.g. Tianshan, Kara), we model their motion within a relative hierarchy for the practical reason that this makes it easier to preserve the consistency of their geological history, as they share multiple plate boundaries with Gondwana. For all these cratons and blocks, we sought to preserve the palaeolatitudes from the parent studies to a reasonable degree allowing for data uncertainties (e.g. Fig. 6). Figure 7 provides a quantitative comparison between the paleolatitudes of the DOM16/18 models and our incorporation of them into our adjusted reconstruction.

\subsubsection{Deviations from DOM16}

The key deviation between DOM16 and our model is a difference in the orientation of Baltica in the late Cambrian (Fig. 12a), where our model has Baltica rotated $90^{\circ}$ counter clockwise relative to DOM16. As the DOM16 model only begins at 500 Ma it does not have to explicitly consider the earlier Neoproterozoic history of Baltica. In our opinion the position of Baltica in DOM16 is more congruent with an inverted Baltica (relative to Laurentia) during the Neoproterozoic (Hartz and Torsvik, 2002), where the southernperi Urals are connected to Greenland. In comparison, MER17 connects Baltica to Rodinia through the Sveconorwegian margin in an upright position relative to the present-day (e.g. Cawood et al., 2003; Dalziel, 1992; Weil et al., 1998). The inverted Neoproterozoic Baltica position of Hartz and Torsvik (2002) results in simpler kinematic motions during the late Ediacaran and Early Palaeozoic, whereas the 'traditional' Neoproterozoic coupling of Baltica-Laurentia requires a more complex motion path in order to fit palaeomagnetic data. However, in our opinion the 'upright' coupling of Baltica and Laurentia is far more geologically and palaeomagnetically robust (Cawood and Pisarevsky, 2006; c.f. Slagstad et al., 2019) in the Neoproterozoic than the alternative, and as such we adopt this configuration at ca. $600 \mathrm{Ma}$ (as in MER17) during the opening of the Iapetus Ocean; necessitating a more complex kinematic evolution for Baltica between 600 and $470 \mathrm{Ma}$ (Fig. 12a ,b). Our reconstruction of Baltica is therefore quite different to that of DOM16 during the late Cambrian and early Ordovician as we have to implement a $\sim 90^{\circ}$ rotation between 520 and $475 \mathrm{Ma}$ of Baltica to fit the same series of palaeomagnetic data at $470 \mathrm{Ma}$ as DOM16.

Baltic palaeomagnetic data compiled by Meert et al. (2014), Torsvik et al. (2012) and Domeier (2016) were used to ensure its latitudinal position remained valid between 550 and $470 \mathrm{Ma}$ (Table 2). Importantly, only

952 two poles - one from the Andarum Shale (Torsvik and Rehnström, (2001) categorised as C-grade quality 953 by Meert (2014)) and the other from the Narva sediments, (Khramov and Iosifidi, (2009), categorised as B- 
grade quality by Meert (2014)) - are identified for Baltica between 530 and $480 \mathrm{Ma}$, both with a nominal age of $500 \mathrm{Ma}$. Despite coeval ages, the poles are $\sim 35^{\circ}$ apart from one another and Meert (2014) identified unresolved issues, specifically: few samples constraining the pole and a (possible) effect of inclination shallowing (even after correction for inclination shallowing a $\sim 25^{\circ}$ mismatch remains). A strict fitting of the Narva sediments pole would require Baltica to rotate by $\sim 2^{\circ} / \mathrm{Ma}$ between 550 and $500 \mathrm{Ma}$; a situation we consider implausible and likely reflecting underlying issues in the palaeomagnetic data. As such, our model does not fit either pole explicitly, though our reconstructed position of Baltica is consistent with the latitude suggested by the inclination data of both poles. By 460-440 Ma, our model closely resembles the DOM16 model, with similar sized Rheic oceans, latitudinal positions and orientations of Gondwana, Baltica and Laurentia (Fig. 12c, d). At 410 Ma, when DOM16 finishes, the only difference is the relative position of Laurasia and Gondwana due to differences in palaeolongitude (Fig. 2c; 11). In our model, Laurussia is much closer to Gondwana resulting in a far narrower Rheic Ocean at $410 \mathrm{Ma}$ than in DOM16/18, DT14 and MAT16 (e.g. Fig. 2c, see also Wu et al. (2020)).

The width of the Rheic ocean is poorly constrained (c.f. Dalziel and Dewey, 2019; Domeier, 2018; Wu et al., 2020) especially because of palaeolongitudinal uncertainty. The problem is compounded by the fact that there is only one reliable palaeomagnetic pole constraining our Gondwana APWP between 430 and $400 \mathrm{Ma}$ (Aïr intrusives in Niger, age at $410 \mathrm{Ma}$, (Hargraves et al., 1987)), meaning the early Devonian portion of the APWP has large uncertainty. Because of this uncertainty, the methods used to create APWPs tend to dampen the effect of this pole (which is true for our APWP). Nonetheless, even with the effect of this pole being dampened, reconstructed palaeomagnetic data (without considering longitudinal constraints) at $410 \mathrm{Ma}$ allow placement of Laurussia and Gondwana to within a few thousand kilometres of one another (e.g. Fig. 11a, see also Wu et al. (2020)). At first glance, this seems problematic, because one might expect that the forces related to subduction zones modelled along the craton margins facing each other would draw the cratons to each other. DOM16, DT14 and MAT16 (along with Torsvik et al., (2014)) solve this problem by changing the palaeolongitude of Laurussia to $90^{\circ}$ east relative to Gondwana, allowing for a much wider ocean basin. This position is justified and necessitated in these models by their use of the PGZ method, where Laurussia is reconstructed over the eastern arm of the present-day position of the Pacific LLSVP. However, this position then requires $>8000 \mathrm{~km}$ of dextral motion between Laurussia and the Patagonian margin of Gondwana from 400 and $340 \mathrm{Ma}$ (e.g. Fig. 3c). As we do not adopt the PGZ method, our position of Laurussia at $410 \mathrm{Ma}$ relative to Gondwana is much closer to its final collision place and the resulting relative motion between Laurussia and Gondwana between 410 and $340 \mathrm{Ma}$ is of sub-orthogonalorthogonal collision along the southern Appalachian zone (Hopper et al., 2017), with some dextral transform motion between north-east Laurentia and the northwest margin of Gondwana (e.g. Murphy et al., 
988 2011) and between southern Baltica and north Gondwana (e.g. Arthaud and Matte, 1977). From 340 to 320

989 Ma YOU19, MAT16 and DT14 have a similar configuration between Laurussia and Gondwana. We stress

990 that while our model this differs from the adopted DOM16 model, it is not a particularly novel interpretation

991 and many continental reconstructions show a similar scenario (e.g. McKerrow et al., 2000; Scotese, 2004;

992 Stampfli and Borel, 2002). A more detailed geological and kinematic justification of this interpretation is

993 presented in Young et al. (2019) and a discussion of the palaeomagnetic challenges in amalgamating Pangea

994 are presented in Domeier et al. $(2020,2012)$ which we encourage interested readers to.

995 


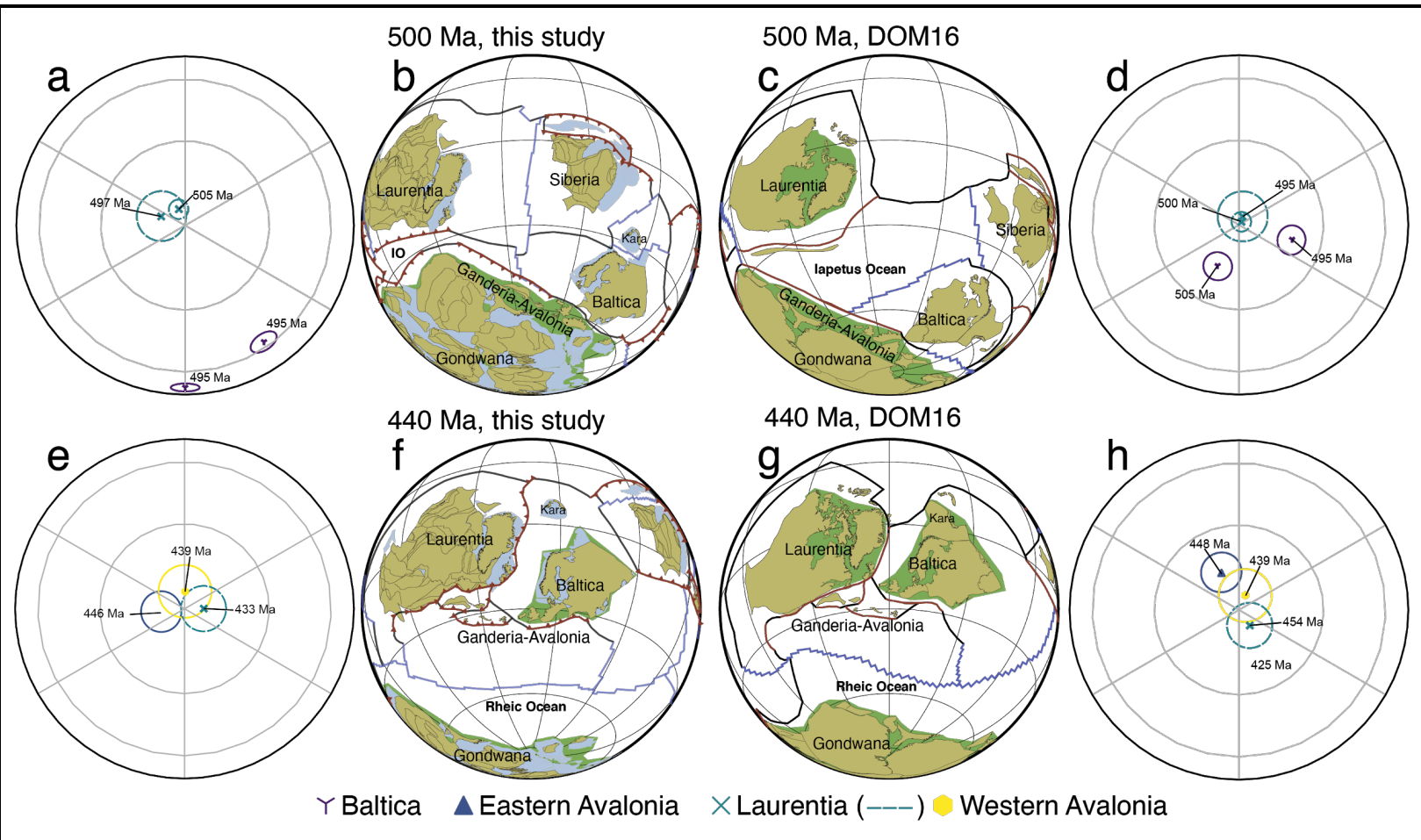

Figure 12

Comparison of the evolution of the Rheic Ocean between our model (a, $500 \mathrm{Ma}$; c, $440 \mathrm{Ma}$ ) and DOM16 (b, $500 \mathrm{Ma}$; d, $440 \mathrm{Ma}$ ) during the early Palaeozoic. We point out the rotational difference (but similar latitude) in Baltica at $500 \mathrm{Ma}$ in our model relative to DOM16, discussed in text. Palaeolongitude is constrained absolutely in DOM16 but not in our model. Subduction polarities are not provided in the GPlates files of DOM16. Tan polygons are areas of continental lithosphere in the Neoproterozoic that we model, blue polygons are areas of present-day continental lithosphere that are inferred to exist during the Neoproterozoic, but without having firm geological evidence or that have been affected by subsequent deformation (e.g. the distance between a present-day coastline and COB). Green polygons represent a schematic interpretation of congruent continental lithosphere, with intervening crust being subsequently deformed during future tectonic cycles. IO, Iapetus Ocean.

\subsubsection{Deviations from DOM18}

Two salient points made by Domeier (2018) pertaining to relative longitude and his model are also of interest here, and worth reiterating when merging DOM18 into the adj-YOU19 model and then extending the adj-YOU19 model into the Neoproterozoic. Firstly, a long lived south-dipping subduction zone, preserved in the northern Kazakhstan terranes of Urumbai, Selety and Erementau (Degtyarev, 2011; Domeier, 2018; Windley et al., 2007) was longitudinally distributed from Siberia through to the northernmost margin of Gondwana (i.e. North Australia, Papua New Guinea) and secondly, the broader framework of Baltica-Siberia-Gondwana provides geological, spatial and temporal limits on the evolution of this area. These two aspects of the model allowed DOM18 to infer with some certainty the relative 
1008 palaeolongitude of many of the smaller terranes within the broader absolute palaeolongitudinal constraints

1009 imposed by (principally) Siberia, Baltica, Laurentia and Gondwana. Likewise, even though we do not adopt

1010 the absolute longitudinal framework of DOM18, we can use the positions of the major cratons to provide a

1011 relative control on the possible kinematic evolution of the Chinese cratons and terranes. We follow DOM18

1012 by reconstructing a quasi-stable south-dipping subduction zone to delimit the northerly extent of the Palaeo-

1013 Tethys Ocean and this, coupled with the palaeomagnetic data from these cratons and terranes between 500

1014 and $410 \mathrm{Ma}$, make longitudinal re-ordering of these blocks unlikely. The unlikeliness of longitudinal re-

1015 ordering is one of the main constraints and pieces of evidence that lead to significant revision of the

1016 positions of Tarim and North China in MER17 that are discussed in the following section (5.4).

1018 The relative positions of terranes (Tianshan, Qaidam-Qilian, Kunlun etc.) can also be considered in a similar 1019 manner to how we conceive of the relative ordering of the Chinese cratons during the Early Palaeozoic. In 1020 particular, the ca. 470 Ma suturing of Tianshan-Chu Yili (Alexeiev et al., 2019) and the 440-430 Ma 1021 suturing of Kunlun, Qaidam, Qilian and Alxa to Tarim (Xiao et al., 2009) both necessitate an internally 1022 consistent relative position between these terranes and Tarim and Siberia in order to be consistent with the 1023 geological record. That is, relative to present-day Tarim, Tianshan, Chu-Yili and other Kazakh terranes 1024 should be reconstructed somewhere north of the northern margin of Tarim during the Ediacaran1025 Ordovician, but south of Siberia. Similarly, Kunlun, Qaidam, Qilian and Alxa need to be reconstructed to 1026 the south and east of Tarim in the same time period. In a plate model framework, this means that the 1027 longitudinal structure of the Proto-Tethyan ocean basin should reconstruct (from west to east): Siberia1028 Chu-Yili-Kazak-Tianshan-Tarim-Alxa-Qaidam-Qilian-Kunlun-North China—South China (e.g. Fig. 1029 13f, g). Further back in time, we also maintain this same configuration to minimise any terrane re1030 organising, such that their relative positioning is broadly reminiscent of present-day (e.g. Figs. 9; 16). In 1031 this manner, we use these relative longitudinal constraints to infer a configuration for the nuclei of these 1032 terranes in the Neoproterozoic, thereby connecting the present-day with their Precambrian history.

1034 The fundamental difference between DOM18 and our implementation of the model is the longitudinal width 1035 of the Proto-Tethyan ocean basin, bounded by Siberia in the west, Gondwana in the east and south and the 1036 aforementioned south-dipping subduction zone in the north (e.g. Fig. 13b, c, f, g). The latitudinal extent of 1037 the ocean basin remains similar in both models $\left(30-50^{\circ}\right)$, constrained by palaeomagnetic data from 1038 Gondwana, Siberia and the Chinese cratons (e.g. Table 2, Fig. 13a, d, e, h). In our model, this ocean basin 1039 is much wider (longitudinally) in the late Cambrian and Ordovician than in DOM18, narrowing in size as 1040 it evolves due to our implemented easterly drift of Siberia from the Cambrian through to the Devonian. The 1041 size of the ocean basin is then similar at $410 \mathrm{Ma}$ (Fig. 11), due to the adopted similarity of the YOU19 from 
1042 the DT14 reconstruction (Young et al., 2019). The key reason for the difference in width at $500 \mathrm{Ma}$ is 1043 because DOM18 places Laurussia further east at $500 \mathrm{Ma}$ than we do (Section 5.2.1). This then forces a 1044 narrower ocean basin between 500 and 410 Ma in DOM18 than in our model. The following paragraphs 1045 will discuss the regional longitudinal constraints of this ocean basin by considering the position of 1046 Gondwana and Siberia.

The Early Palaeozoic position of Siberia in our model is a function of palaeomagnetic data and its position 1049 in, and breakout from, Rodinia. In isolation, the simplest explanation of Siberia's journey is that sometime 1050 during the late Tonian-Cryogenian (750-700 Ma) Siberia rifted off the northern margin of Laurentia 1051 (somewhere near Greenland, see Pisarevsky and Natapov (2003) and Pisarevsky et al. (2013)). At this time 1052 Siberia was located equatorially and rotated $60^{\circ}$ clockwise from its present-day orientation (Pisarevsky et 1053 al., 2013). Palaeomagnetic data are sparse for the remainder of the Neoproterozoic, with the few calculated 1054 poles having either poor age constraints or unresolved tectonic coherence with the Siberian craton (Pavlov 1055 et al., 2015), and are therefore typically omitted from syntheses (Cocks and Torsvik, 2007; Li et al., 2008; 1056 Merdith et al., 2017a). However, from the mid-Cambrian the palaeomagnetic record of Siberia is reasonable 1057 (Cocks and Torsvik, 2007) and broadly congruent with the palaeolatitude of the 750 Ma pole (that is, 1058 equatorial-sub-equatorial). From the mid-Cambrian, the data suggest a slow northward drift and counter1059 clockwise rotation (Cocks and Torsvik, 2007), with the orientation of Siberia at ca. 530 Ma inverted relative 1060 to present-day. This then requires a $\sim 120^{\circ}$ clockwise rotation between 720 and $530 \mathrm{Ma}$ in order to fit its 1061 Neoproterozoic position (Metelkin et al., 2012). For the Cryogenian and Cambrian, Siberia's motion can be 1062 inferred indirectly using data from Baltica, as outlined in the next paragraph.

1064 The position of Baltica is constrained by clusters of palaeomagnetic data during the Ediacaran and early 1065 Cambrian. Furthermore, its latitudinal position places limits on the possible position of Siberia. The 1066 equatorial excursion of Baltica in the latest Ediacaran places Baltica at a latitude similar to Siberia. As they 1067 cannot be positioned on the same longitude (Merdith et al., 2017a), Siberia must be lcoated either 1068 longitudinally east or west of Baltica between 600 and $500 \mathrm{Ma}$ (with Laurentia also occurring on a similar 1069 palaeolatitude but further east than either Siberia or Baltica). Domeier (2018) presented similar arguments 1070 for the second latitudinal excursion of Baltica (it returns to a high latitude during the Ordovician-Silurian) 1071 when it collided with Laurentia to form Laurussia at ca. 440-430 Ma. He argued that the overlapping 1072 palaeolatitudes of Siberia and Baltica at this time then requires Siberia to be located more easterly than 1073 Baltica by ca. $470 \mathrm{Ma}$ (Domeier, 2018). We also adopt this logic, thus providing a rough relative 1074 longitudinal framework for Laurentia-Baltica-Siberia relations from 700 to $450 \mathrm{Ma}$. 
1076 Our model requires the motion of Siberia to be predominantly longitudinal between 700 and $450 \mathrm{Ma}$ (the

1077 available palaeomagnetic data do not suggest more than $30^{\circ}$ latitudinal movement). We constrain this to 1078 two broad phases of movement, defined by Baltica's two latitudinal excursions (at ca. $560 \mathrm{Ma}$ and $450 \mathrm{Ma}$ ). 1079 In the first excursion (750-550 Ma), we keep Siberia longitudinally between Laurentia and Baltica, because 1080 to move it further east than Baltica at $550 \mathrm{Ma}$ would require relative plate motion greater than $30 \mathrm{~cm} / \mathrm{a}$, 1081 which we deem unlikely. By 470 Ma palaeomagnetic data from Baltica suggest it has started drifting north 1082 again, so we therefore reconstruct Siberia to also be moving east longitudinally between 550 and $470 \mathrm{Ma}$, 1083 such that by $470 \mathrm{Ma}$ it is located along the same longitude as Baltica; by $450 \mathrm{Ma}$ it is further east than 1084 Baltica, such that Laurussia can form by 430 Ma. Our model is therefore similar to that of DOM18 in 1085 concept and adherence to available observations, however the different absolute longitudinal positions 1086 create a notably different ocean basin in the late Cambrian and Ordovician, within which the Chinese 1087 cratons and terranes are then arranged.

1089 Domeier (2018) does not explicitly consider the Neoproterozoic or Early Palaeozoic evolution of the 1090 Chinese cratons in his model. At $500 \mathrm{Ma}$, the DOM18 model places North China off the northern margin 1091 of India, and South China off northern Australia. However, retaining these relationships in the 1092 Neoproterozoic is invalidated by what Neoproterozoic palaeomagnetic data exists for each craton (e.g. Fu 1093 et al., 2015; Li et al., 2004), and also conflicts with interpreted geological histories (Cawood et al., 2018b, 1094 2013b). Consequently, our model, which balances both older and younger times, alters the kinematic 1095 evolution in order to fit older constraints (Fig. 13, Sections 5.4.1 and 5.4.2). 


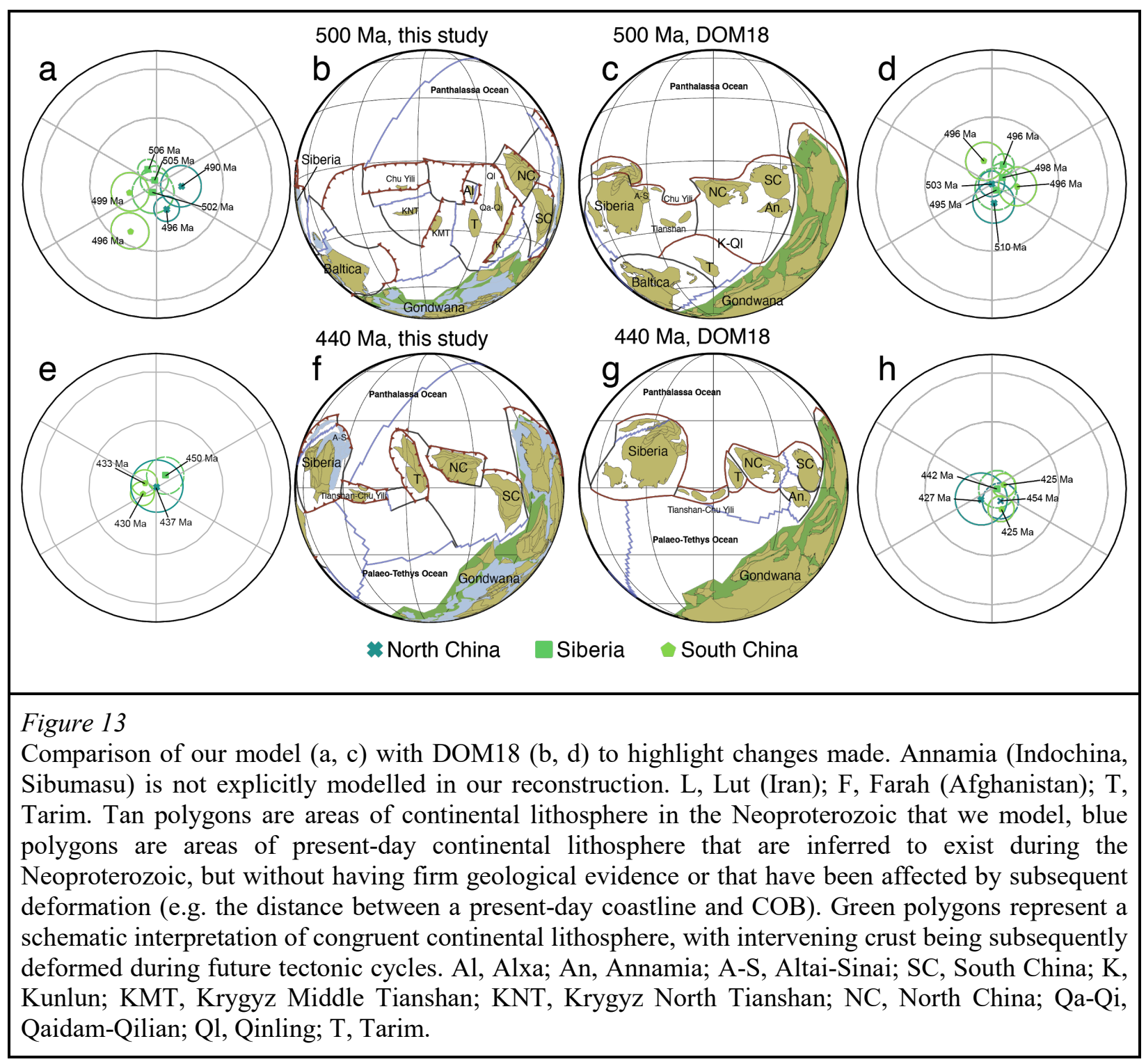

5.4 MER17

\subsubsection{Australia, North China, Lhasa and Tasmania}

1101 Significant alterations to MER17 were made between 1000 and $900 \mathrm{Ma}$ along the north-western, western 1102 and south-western margins of Laurentia, affecting the motions and positions of Australia, North China, 1103 Siberia, Tasmania and Lhasa. We adopt the model of Wen et al. (2018) in having a dextral shear zone 1104 between Australia-Antarctica (A-A) and Laurentia during the early Tonian. Wen et al. (2018) argued for 1105 placing Tarim against the eastern margin of Laurentia, separating Laurentia from Australia in a 'Missing 1106 Link' position (cf. (Li et al., 2008, 1995), with the dextral shear zone transecting Tarim. However, we 1107 consider this position for Tarim is incompatible both with geological data (the 760 Ma Aksu Blueschist 1108 (C.-L. Zhang et al., 2013)) and with the kinematic constraints that would be necessary to move Tarim from 
1109 this position to its Palaeozoic position (e.g. Merdith et al., 2017b). We therefore use the alteration of Wen 1110 et al.'s (2018) model presented in Mulder et al. (2018b), who place a dextral boundary separating the 1111 Antarctic crust of Australian affinity exposed in Terre Adélie Land from the Antarctic crust of Laurentian 1112 affinity in the Nimrod Igneous Province (Fig. 14a, see also Goodge et al., (2017)).

1114 North China and northern Australia share a similar Mesoproterozoic and early Tonian sedimentary record 1115 and both preserve contemporaneous ca. 1.33-1.31 Ga magmatism (Bodorkos et al., 2020; Yang et al., 2020; 1116 Zhang et al., 2017) that is interpreted as a large igneous province. Yang et al. (2019) also demonstrated the 1117 similarity in detrital zircon ages and hafnium isotope compositions between the Tonian strata of both areas.

1118 We find that this position of North China in the latest Mesoproterozoic is remarkably compatible with the 1119 few reliable palaeomagnetic data for North China in the Neoproterozoic (e.g. Fig 6, (e.g. Fig. 6, Fu et al., 1120 2015) and places North China in a position readily compatible with its Palaeozoic constraints where the 1121 same species of distinctive tommotiid fossils have recently been reported (Pan et al., 2018). A distinct Sino1122 Australian Cambro-Ordovician faunal province was identified by Burrett et al. (1990) that suggests some 1123 proximity in the early Palaeozoic. Cambrian-Ordovician rifting in the Arafura Basin north of northern 1124 Australia may represent the initial separation of North China from this margin of Gondwana (Ahmad and 1125 Munson, 2013). Palaeomagnetic data necessitate some relative motion between Australia and North China 1126 in the Early Palaeozoic from its inferred Mesoproterozoic-Neoproterozoic position (e.g. Domeier, 2018). 1127 Given there is no evidence of orogenesis between North China and northern Australia in the Phanerozoic, 1128 we infer that North China slowly drifts off this margin from the Cambrian, remaining in close enough 1129 proximity to share the identified Cambro-Ordovician faunal provinces (e.g. Fig. 13).

1131 Dong and Santosh (2016) and Dong et al. (2014) describe a 1000 to 900 Ma suture between the Qinling 1132 Terrane and North China, preserved as the Kuanping Ophiolite (Fig. 14a-c). As Siberia and Australia are 1133 reconstructed adjacent to each other in Rodinia (Pisarevsky et al., 2013), the position of North China along 1134 the northern margin of Australia suggests that the Qinling terrane could feasibly be an extension of the 1135 Central Angara terrane, where there is a similarly aged (but sparsely described) ophiolite, the Ribnaya1136 Panimba ophiolite (Vernikovsky et al., 2004, 2003). In our model, the subduction zones represented by 1137 these two ophiolites consume the oceanic lithosphere between Australia, Siberia and Laurentia (the 1138 Kuanping Ocean) during the early Tonian. Mulder et al. (2018b) ceased motion at 900 Ma in their model 1139 but, we adjust this cessation to $930 \mathrm{Ma}$ wherein the Qinling Terrane rotates to fit against the North China 1140 block. This is because we also reconstruct the Lhasa block along the western margin of Australia ((Zhu et 1141 al., 2011), see Section 5.1) and here magmatism is preserved from ca. $925 \mathrm{Ma}$ (Guynn et al., 2012, 2006; 1142 Hu et al., 2018; Zeng et al., 2018) (Fig. 14d,e). Consequently, we suggest that this subduction initiated after 
1143 the closure of the interior Kuanping Ocean and collision of North China-Australia-Antarctica with Siberia-

1144 Laurentia along the Qinling-Central Angaran Terrane. The subduction zone then connects northwards 1145 through to subduction preserved in Taimyr outboard of Siberia (Vernikovsky et al., 2004; Vernikovsky and 1146 Vernikovskaya, 2001) and southward into an oceanic arc outboard of the Mawson Craton of Antarctica, 1147 possibly preserved in the southernmost Tonian Oceanic Arc Super Terrane (TOAST) or between Indo1148 Antarctica and Australia-Antarctica). In our model, Australia sits in a typical SWEAT (South West United 1149 States, East Antarctica) configuration (Moores, 1991). We made this change to better fit the arguments put 1150 forward by Mulder et al. (2018b), while still maintaining integrity of relative plate kinematics following 1151 the reasoning of Merdith et al. (2017b).

1153 Our revised model also incorporates recent refinements to the Proterozoic and early Palaeozoic 1154 paleogeography of the Western Tasmania Terrane. The Western Tasmania Terrane, comprising the 1155 Proterozoic geology of Tasmania and the East and West South Tasman Rises (Berry et al., 2008), occupies 1156 an important position in deciphering the geological relationship between Laurentia and Australia-Antarctica 1157 in Rodinia, and also in understanding the transition between Rodinia to Gondwana. The Western Tasmania 1158 Terrane represents an exotic Proterozoic microcontinent that was accreted onto the Pacific margin of eastern 1159 Gondwana in the late Cambrian during the Ross-Delamerian orogenic cycle (Berry et al., 2008; Cayley, 1160 2011). The terrane has geological affinities with the central Transantarctic Mountains of East Antarctica 1161 and the western margin of Laurentia, including overlapping Palaeoproterozoic basement ages, 1162 contemporaneous Mesoproterozoic magmatic and fluid-flow events, and correlated Mesoproterozoic 1163 sedimentary strata (Berry et al., 2008; Fioretti et al., 2005; Halpin et al., 2014; Mulder et al., 2015, 2018b). 1164 Based on these geological connections, the Western Tasmania Terrane was likely located between East 1165 Antarctica and western Laurentia within an assembled Rodinia. The breakout of the Western Tasmania 1166 Terrane from its central position within Rodinia is recorded by widespread Tonian-Ediacaran 1167 sedimentation and rift-related magmatism (Mulder et al., 2020). The onset of Neoproterozoic rifting of the 1168 Western Tasmania Terrane is marked by 780-750 Ma intraplate magmatism (Black, 1997; Calver et al., 1169 2013) and latest Tonian (750-730 Ma) siliciclastic and carbonate sedimentation (Calver et al., 2014; Mulder 1170 et al., 2018a). Following deposition of Cryogenian rift-related strata and glaciogenic intervals (Calver, 1171 2011; Calver et al., 2014) a final pulse of Neoproterozoic rifting is recorded by voluminous ca. 580 Ma rift1172 related basalts in northwest Tasmania (Direen and Crawford, 2003; Meffre et al., 2004). Geological 1173 correlations permit the Western Tasmania Terrane to have remained attached to either the western margin 1174 of Laurentia or the eastern margin of Australia-Antarctica following the opening of the Pacific Ocean (Fig. 1175 10f), prior to being isolated as a microcontinent during ca. 580 Ma rifting and accretion onto its present1176 day position along the margin of Gondwana by the late Cambrian (Fig. 10g; Berry et al., 2008; Mulder et 
1177 al., 2020). We follow Mulder et al. (2020) in having Tasmania rift from the Antarctic margin (rather than 1178 the alternative scenario of Laurentia), thus implying that some further unknown micro-continents rifted 1179 from the western margin of Laurentia at the same time in order to account for that passive margin (e.g. Fig. 1180 14f, g Macdonald et al., 2013) (see also Colpron et al., 2002; Cox et al., 2018; Eyster et al., 2019).

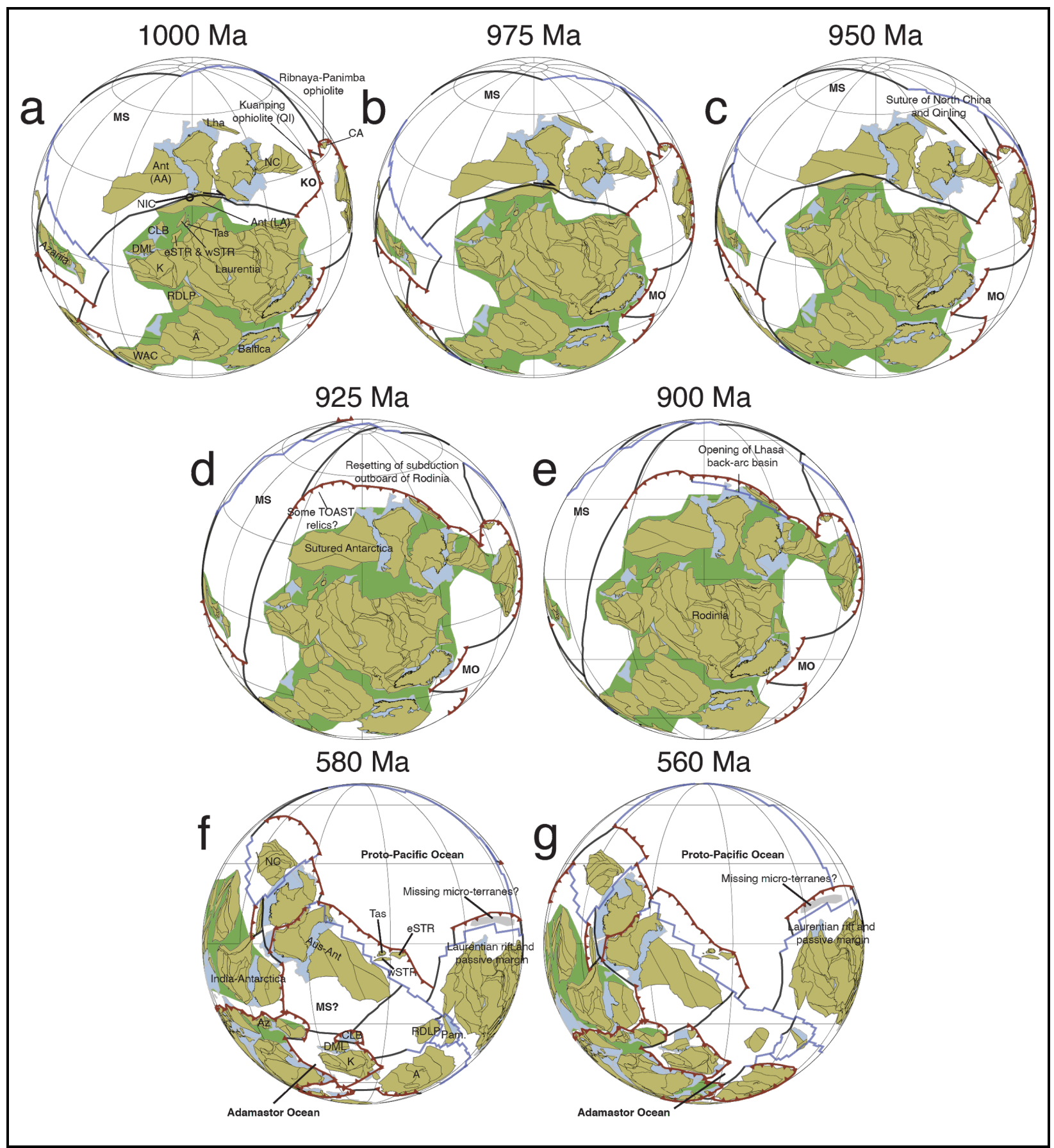


Figure 14

Snapshots of plate reconstructions showing our updated model for Australia-Laurentia at key time intervals, along with palaeomagnetic data. (a) $1000 \mathrm{Ma}$; (b) $975 \mathrm{Ma}$; (c) $950 \mathrm{Ma}$; (e) $925 \mathrm{Ma}$; (f) $900 \mathrm{Ma}$; (h) $580 \mathrm{Ma}$ and (i) $560 \mathrm{Ma}$. The Tonian model (a-f) follows arguments laid out in Mulder et al. (2018b), while the Ediacaran-Cambrian evolution is after Mulder et al. (2020). Times in these panels reflex the nominal time of best fit for each pole. Tan polygons are areas of continental lithosphere in the Neoproterozoic that we model, blue polygons are areas of present-day continental lithosphere that are inferred to exist during the Neoproterozoic, but without having firm geological evidence or that have been affected by subsequent deformation (e.g. the distance between a present-day coastline and COB). Green polygons represent a schematic interpretation of congruent continental lithosphere, with intervening crust being subsequently deformed during future tectonic cycles. CLB: Coats Land Block; DML, Dronning Maud Land; eSTR: Eastern South Tasman Rise; MO, Mirovoi Ocean; MS, Mawson Sea; Tas: Tasmania; wSTR: Western South Tasman Rise; RDLP: Río de la Plata; WAC, West African Craton.

\subsubsection{India-South China Accretionary Belt}

1184 We preserve the MER17 interpretation of a tight India-South China connection (after Cawood et al., 2013b).

1185 This possible connection was suggested previously by Jiang et al. (2003) who noted the similarity between

1186 sequence stratigraphy in rift basins preserved in both South China and the Indian Lesser Himalaya (Fig.

1187 15a), as well as by Hofmann et al. (2011) who suggested a geological similarity based on detrital zircon

1188 analysis. Arguments for this connection are succinctly summarised in Cawood et al. (2018b) and are not

1189 repeated here - instead we focus our discussion of this margin on the relative position of outboard terranes

1190 during the Neoproterozoic (Fig. 15), which are based predominantly on their Palaeozoic positions

1191 (Domeier, 2018). Here we have sought to preserve their relative internal positions in order to minimise

1192 reshuffling of terranes during the Neoproterozoic (e.g. Fig. 16). For example, Kunlun, which is currently

1193 preserved south of Tarim and west of Qaidam-Qilian, is always reconstructed with the same internal

1194 consistency. Although we note that this may not be an accurate reflection of the ordering and positioning

1195 of the terranes, it ensures consistency within the model and minimises terrane shuffling which can preclude

1196 unrealistic scenarios, where terranes have to kinematically skirt one another precariously. Figure 16 gives

1197 a schematic overview of our conceptualisation and implementation of this model.

1199 Following Alessio et al. (2018) and Armistead et al. (2019), the northwest margin of India is here interpreted

1200 as an extensive Stenian-Tonian accretionary margin that extends as far as the Omani basement and

1201 northernmost Madagascar. The pre-Ediacaran basement rocks in Rajasthan and Pakistan share similarities

1202 with those of Oman. Granitoids have been dated from Rajasthan and from Nagar Parkar in eastern Sind

1203 (Pakistan) at ca. 1.1 Ga (Meert et al., 2013; Raza et al., 2012). There is no evidence of older crust occurs

1204 west of the Western Margin Fault of the Aravalli-Delhi Orogen, where the Marwar terrane accreted to India

1205 in the latest Mesoproterozoic (Meert et al., 2010) (Fig. 15b). Tonian granitoids and rhyolites occur in inliers 
1206 through northwest India and Pakistan, where they cluster into crystallisation ages of ca. 990-970 Ma

1207 (Haldar and Deb, 2001; Pandit et al., 2003), ca. 860-820 Ma (Davies and Crawford, 1971; Deb et al., 2001;

1208 Just et al., 2011; Van Lente et al., 2009) and ca. 775-760 Ma (Ashwal et al., 2013; Gregory et al., 2009;

1209 Meert et al., 2013; Van Lente et al., 2009). The latter magmatic and extrusive phase forms one of the largest

1210 felsic igneous provinces on the planet - the Malani Igneous Suite - which is also traced to the Seychelles

1211 (Fig. 15c-e) (Torsvik et al., 2001; Tucker et al., 2001). Arc accretion continued outboard to Oman where

1212 two main phases of subduction and arc magmatism occur, at ca. $850 \mathrm{Ma}$ and ca. $770 \mathrm{Ma}$ (Blades et al.,

1213 2019a). The latter phase focussed in the southern Mirbat area and interpreted here as the arc that formed

1214 ocean-ward of the more back-arc Malani Igneous Suite. Further outboard still, and later accreting onto the

1215 Indian margin, the Bobakindro Terrane of northern Madagascar (Armistead et al., 2019) consists of juvenile

1216 magmatism that dates from ca. 750-705 Ma (Armistead et al., 2019; Collins, 2006; Thomas et al., 2009).

1218 Many terranes currently preserved north of South China and south of Siberia have Neoproterozoic or older 1219 cores. They have not been previously considered in global models (Li et al., 2008; Merdith et al., 2017a) 1220 due to the sparsity of data and small size of terranes, which invites many competing and conflicting 1221 interpretations of their history. However, in the construction of this continuous plate model, where spatial 1222 and temporal continuity is vital, the most compatible Tonian position for these terranes was outboard of the 1223 afore-discussed large accretionary subduction zone of South China and India. This position places them in 1224 the most favourable kinematic, palaeomagnetic and geologically plausible positions for their (more well 1225 constrained) Palaeozoic journeys (e.g. Charvet et al., 2011; Domeier, 2018; Xiao et al., 2013). Below we 1226 summarise some geological evidence for this, with particular reference to the Tarim Craton, as it is the only 1227 block that has multiple reliable palaeomagnetic data from the Neoproterozoic that act as a another line of 1228 evidence. We also note that Huang et al. (2019) recently proposed a location outboard of Greenland for the 1229 Yili-Tianshan Block on the basis of similar detrital zircon age spectra. However, more work would have to 1230 be done to determine whether this Tonian position is consistent with the kinematic evolution necessary for 1231 these blocks to fit their Palaeozoic constraints. 

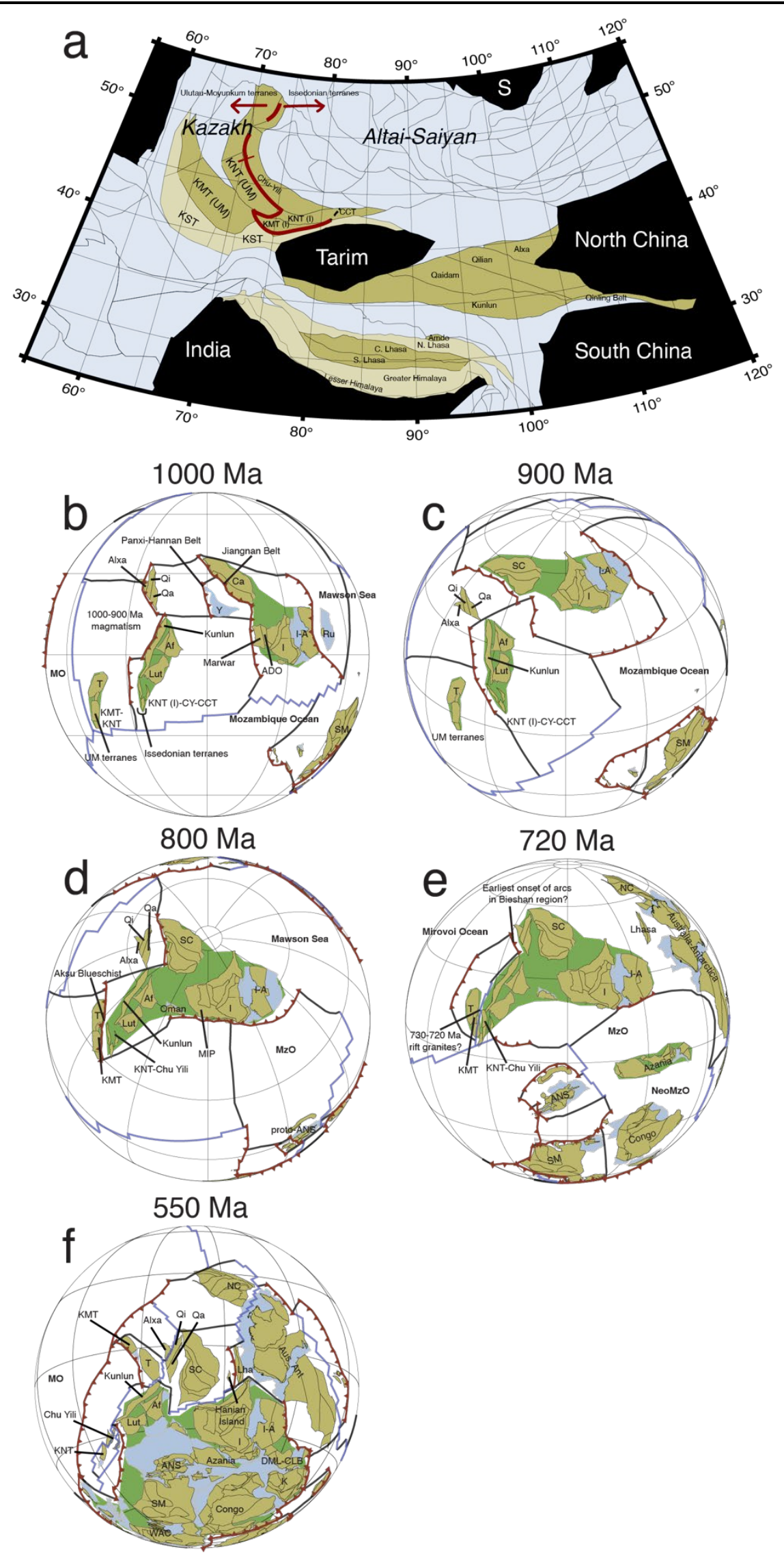
Figure 15

(a) Regional map at present day of Central Asian Orogenic Belt with modelled terranes highlighted in tan. Light tan terranes are not explicitly modelled but are referred to in the main text. Black areas represent the cratonic components. For the Kazakh area, we use polygons consistent with their Palaeozoic structure. The size, orientation and distribution of crust in these terranes in the Neoproterozoic is unknown due to the subsequent reworking of the terranes. Therefore, the precise position (along a margin), orientation, size and shape of these terrane polygons in the reconstruction figures are speculative and should be treated cautiously. (b-f) Evolution of the India-South China system during the Tonian-Cryogenian at key times. Tan polygons are areas of continental lithosphere in the Neoproterozoic that we model, blue polygons are areas of present-day continental lithosphere that are inferred to exist during the Neoproterozoic, but without having firm geological evidence or that have been affected by subsequent deformation (e.g. the distance between a present-day coastline and COB). Green polygons represent a schematic interpretation of congruent continental lithosphere, with intervening crust being subsequently deformed during future tectonic cycles. ADO = Aravalli-Delhi Orogen; Af, Afghanistan; Aus-Ant, Australia-Antarctica; Ca, Cathaysia; DML-CLN, Dronning Maud Land-Coats Land Block; I, India; I-A, Indo-Antarctica; KNT (I/UM), Krygyz North Tianshan (Issendonian/Ulutau-Moyunkum); KMT (I/UM), Krygyz Middle Tianshan (Issendonian/Ulutau-Moyunkum); MIP, Malani Igneous Province; MO, Mirovoi Ocean; MzO, Mozambique Ocean; NC, North China; NeoMzO, Neomozambique Ocean; Qa, Qaidam; Qi, Qilian; Ru, Ruker; SC, South China; SM, Sahara Metacraton; T, Tarim; WAC, West African Craton; Y, Yangtze.

1234 Early Tonian age (1000-900 Ma) magmatism and high-pressure metamorphism is preserved in the 1235 basements of the Qilian-Qaidam (Qi-Qa), Kunlun and Tianshan-Chu Yili terranes (Song et al., 2012; Tung 1236 et al., 2007; Wu et al., 2017). Importantly Song et al. (2012) identified an early Tonian event preserved in 1237 a high-pressure metamorphic belt in Qi-Qa. Here, a $\sim 200 \mathrm{~km}$ linear belt of granitic gneisses, 1238 metamorphosed in the Palaeozoic, have crystallisation ages between ca. 1000 and 900 Ma (Song et al., 1239 2012). Zircons recovered from pelitic and psammitic gneisses from the same belt possess multiple 1240 generations of growth, as suggested through cathodoluminescence imaging, and return ages of the (first 1241 generation) to between ca. 940 and $900 \mathrm{Ma}$ (Song et al., 2012). These are interpreted to represent a period 1242 of granulite facies metamorphism from a continental arc indicating that subduction was active during the 1243 Early Tonian (Song et al., 2012). Song et al. (2012) and others (e.g. Zhang et al., 2008) suggested a link 1244 between these two blocks and South China on the basis of similar-aged magmatism and metamorphism.

1245 However, as the Qi-Qa preserves a different Palaeozoic tectonic history to South China, as opposed to 1246 fragments of older lithosphere preserved in the Panxi-Hannan Belt of the Yangtze Craton, we suggest that 1247 a subduction zone was located outboard of Qi-Qa while a secondary, smaller ocean was closing between 1248 Qi-Qa and the accretionary orogen of the Panxi-Hannan Belt (Fig. 11a-c). Upon the suturing of Yangtze 1249 with Cathaysia (ca. 900 Ma, Fig. 11b), subduction relocated outboard of South China and began to close 1250 the ocean between Qa-Qi and South China. Similar to the Qi-Qa, the Kunlun terrane preserves scattered 1251 magmatic ages of S-type granites and protoliths of orthogneiss and amphibolites ranging between ca. 1000 1252 and $900 \mathrm{Ma}$ (Chen et al., 2008; He et al., 2018; and Chen et al., 2006a; 2006b — both cited in Chen et al., 1253 2008; He et al., 2018). We interpret these rocks and ages as an extension of the same subduction zones 
1254 outboard of Qi-Qa, and extend it further to the south where (again) similar-aged magmatism is also 1255 preserved in the North Tianshan and Chu-Yili (Degtyarev et al., 2017).

1257 The Kazakh terranes (including Krygyz Tianshan and Chu-Yili, Fig. 15a) have poorly constrained 1258 Neoproterozoic histories, with only a handful of ages from outcropping magmatic rocks and sedimentary 1259 successions. We predominantly follow the summary of Degtyarev et al. (2017) in offering a possible 1260 tectonic interpretation of their Neoproterozoic geological history that is linked to the wider globe. 1261 Degtyarev et al. (2017) note that there are two broad categories of Precambrian terranes preserved in the 1262 Kyrgyz-Tianshan-Yuli area; the Issedonian and Ulutau-Moyunkum terranes. The Issedonian terranes, 1263 preserved in the northeast of the western Central Asian Orogenic Belt, include Chu-Yili and the Chinese 1264 Central Tianshan and are characterised by late Mesoproterozoic magmatism (e.g. Degtyarev et al., 2011), 1265 thick (> 1000 m) 1050-950 Ma quartzite-schist successions followed by ongoing magmatism from ca. 9601266890 Ma (e.g. Degtyarev et al., 2008; Gao et al., 2015; Huang et al., 2015). Comparably, the Ulutau1267 Moyunkum terranes are preserved only in the west (in Krygyz) within Kyrgyz Middle Tianshan and Krygyz 1268 North Tianshan (e.g. Fig. 10b), and consist of a Palaeoproterozoic basement, with predominantly 1269 sedimentary Mesoproterozoic and early Neoproterozoic rocks (Degtyarev et al., 2017). Magmatism, 1270 between 840 and $760 \mathrm{Ma}$ (Kröner et al., 2012) and granulite facies metamorphism from 800-760 Ma 1271 (Degtyarev et al., 2017; Tretyakov et al., 2016) are recorded only in the late Tonian. Both sets of terranes 1272 preserve distinct differences in their Mesoproterozoic histories, minor differences in the Early 1273 Neoproterozoic histories but similar histories from the mid-Neoproterozoic (ca. $700 \mathrm{Ma}$ ) onwards, 1274 suggesting proximity sometime during the late Tonian (800 to 700 Ma?) (Degtyarev et al., 2017). We 1275 interpret the Issedonian terranes to be the southernmost extent of the subduction zone spanning Qi-Qa and 1276 Eastern Kunlun, as the magmatism preserved in the Issedonian terranes has a continental arc signature 1277 (Huang et al., 2014) and is broadly coeval. Comparably, the Ulutau-Moyunkum terranes, which share 1278 Mesoproterozoic similarities to Tarim and record no magmatism in the early Neoproterozoic, are located 1279 on the opposite side (lower plate) of a closing ocean basin. This culminates with the collision of Tarim 1280 (with the Ulutau-Moyunkum terranes) and the combined India-South China continent at ca. 800-760 Ma 1281 along the Issendonian margin (Fig. 11d, e). The sparse data and age constraints from these terranes means 1282 much of their Neoproterozoic history is conjectural. Although the specific orientation and positioning of 1283 the terranes along the margin is speculative our interpretation is that it places the Kazakh terranes in a 1284 favourable position for their Palaeozoic evolution which is, comparably, much better constrained.

1286 Two clusters of Neoproterozoic-aged palaeomagnetic data from Tarim make it difficult to elucidate a 1287 consistent position with other palaeomagnetic data from Rodinian constituents. Three poles from the Tonian 
1288 and Cryogenian require a $90^{\circ}$ rotation of Tarim in order to fit the younger pole of Wen et al. (2017), or a $1289180^{\circ}$ rotation to fit the cluster of three poles in the Ediacaran to Cambrian (see Merdith et al. (2017a) and

1290 Section 4.2 for a discussion). Within a self-consistent kinematic plate boundary framework, this motion is 1291 not permissible if Tarim is positioned either against north-western Australia (e.g. Zhang et al., 2012) or as 1292 an extension of the 'Missing-Link' model (Li et al., 2004 for the original proposal of the "Missing-Link" 1293 model; Wen et al., 2018, 2017). A plausible position where these palaeomagnetic criteria are met, along 1294 with satisfying key geological evidence, such as the 800-760 Ma Aksu Blueschist preserved on the northern 1295 margin of Tarim(C.-L. Zhang et al., 2013), is outboard of the India-South China accretionary belt, where it 1296 acts as the final piece of continental lithosphere accreted to the margin. In our model, we suggest the 1297 metamorphism recorded by the Aksu Blueschist marks the accretion of Tarim to Chu-Yili and the Tianshan 1298 (see Xia et al. (2017) for the most recent discussion, but see also data and discussion from Zhang et al. 1299 (2012, 2009). To accommodate the change in position suggested by the palaeomagnetic data, we introduce $1300 \mathrm{a} \sim 120^{\circ}$ rotation of Tarim and Southern Tianshan away from this margin, such that Tarim's southern margin 1301 collides with the outboard margin of Alxa-Qaidam-Qilian, so its northern margin faces an open ocean basin, 1302 allowing it to rift northward facing as Gondwana forms towards its more well constrained Palaeozoic 1303 position (Fig. 16).

1304

1305 To support this interpretation of Tarim's evolution we present the following geological observations in 1306 support of this model. Firstly, there is an absence of extensive magmatism on either the northern or southern 1307 margin of the Tarim craton between 1000 and $850 \mathrm{Ma}$, which makes it difficult to include as a part of the 1308 upper-plate circum-Rodinian subduction girdle (Cawood et al., 2016). Previous studies, including MER17, 1309 place Tarim on the margin of Rodinia typically also include the Chu Yili and Tianshan crust attached in a 1310 quasi-present-day configuration to the northern margin of Tarim. In such cases their record of Tonian 1311 magmatism supports the interpretation that they formed part of the circum-Rodinian subduction girdle (Ge 1312 et al., 2014) however, this location is inconsistent with available palaeomagnetic data (e.g. (Wen et al., 1313 2018). Secondly, rift related granitoids preserved in the Southern Tianshan (Degtyarev et al., 2017; Gao et 1314 al., 2015) are here interpreted as evidence of the re-adjustment of Tarim between 730 and 680 Ma to account 1315 for the change in palaeolatitude and orientation inferred from palaeomagnetic data (Fig. 11e). In addition, 1316 extensive rifting in the southwest of Tarim (Wang et al., 2015) is interpreted to reflect the rearrangement 1317 of subduction after Tarim/India-South China amalgamation. This motion is similar to the adjustment of 1318 Baltica relative to Laurentia in the latest Mesoproterozoic proposed by Cawood et al. (2010) to account for 1319 the Valhalla Orogeny. Xiao et al. (2010) summarise the geology and geochronology of rocks found in the 1320 Beishan area of China which record a protracted and complex history of multiple arc development and 1321 accretion through the late Neoproterozoic and Early Palaeozoic. Rocks in the Beishan area (Alxa, Fig. 15, 
1322 16) range from low-grade sedimentary metamorphic assemblages to gneiss and eclogite complexes and 1323 intrusive granitic bodies that have late Neoproterozoic-Cambrian ages (Xiao et al., 2010). These rocks, 1324 inferred to represent an active subduction zone and accretionary complex, are unconformably overlain by 1325 Cambrian-Ordovician sediments. The earliest record of metamorphism in the area are from a series of 1326 SHRIMP U-Pb ages taken from the metamorphic rims of zircons of an eclogite unit at ca. 830-800 Ma 1327 (Yang et al., 2006).

With respect to the palaeomagnetic issues of Tarim we raised earlier (Section 4.2), we find that our conceptual model of this rotation of Tarim (e.g. Fig. 16) can fit either set of palaeomagnetic data equally as well, with the key factor being the time of subduction in the Beishan area. Under the cluster of three poles, the motion of Tarim occurs more quickly and peak subduction (possibly resulting in a collision?) would be earlier (ca. $650 \mathrm{Ma}$ ), while to fit the pole of Wen et al. (2017) it would occur later at between 600 and $550 \mathrm{Ma}$. Based on the review of Xiao et al. (2010), we infer that the geological data support the later interpretation more strongly however, given the novelty of this scenario and the absence of identifiable piercing points, it could be revised in the future to fit the alternative scenario. (Kunlun, Qa-Qi, Chu Yili and Tianshan) that we have placed on this Indian-South Chinese accretionary margin, however, the high degree of reworking and suturing of crust from the terranes, coupled with the small size of these terranes makes it difficult to pin down precise rift times. We stress that our interpretation here is preliminary, especially when compared to specialised reviews of the tectonics of this area (Kroner et al., 2007; Wilhem et al., 2012; Windley et al., 2007; Xiao et al., 2013; Yakubchuk, 2017). We reiterate that our intention here is to provide a possible framework that connects and contextualises these terranes within a consistent kinematic and tectonic evolution between the Neoproterozoic and Palaeozoic (Fig. 16), which can be more tightly refined in the future. Ordovician-Silurian sutures between Qa-Qi-Kunlun and surrounding cratons preserve late Neoproterozoic-Cambrian ophiolites (Jian et al., 2014; Shi et al., 2018; Song et al., 2013, 2009) thus necessitating the existence of ocean basins, but there are few dates of ocean basin initiation. Xu et al. (2015) date Qilian-Qaidam continental rift basalts to 600-580 Ma, constraining ocean basin formation to the latest Ediacaran-earliest Cambrian, with the oldest ophiolite (the Yushigou Ophiolite) preserved in these terranes dated to $550 \mathrm{Ma}$ (Shi et al., 2004). Evidence of rifting is more sparse in Kunlun, however, similar stratigraphy, ages and geochemistry of metavolcanic deposits between Kunlun and Qaidam-Qilian (Yuan et al., 2004) suggest coeval rifting is reasonable, though not definite. We follow some recent work (Peng et al., 2019; Zhao et al., 2018) in having separation of Tarim and these terranes in the late Ediacaran (550 Ma here, as a response to the closure of the Mozambique Ocean between India and 
1356 Congo). Our model closely resembles the schematic framework outlined by Qiantao et al. (2001), while 1357 also following Domeier (2018) in maintaining a very close affinity between Kunlun, Q-Q and Alxa for the 1358 Early Palaeozoic, such that they conceptually form a single elongated terrane that rifts off Gondwana at ca. $1359550 \mathrm{Ma}$ and collides along the southern margin of Tarim by $440 \mathrm{Ma}$.

Comparably, rifting on the northern margin of Tarim is easier to constrain. Thick, late Neoproterozoic 1362 sedimentary sequences capped with carbonate and an unconformity on the Ediacaran-Early Cambrian 1363 imply a prolonged rift phase with breakup at ca. 550-540 Ma (Zhao et al., 2014; Zhu et al., 2017). Similarly, 1364 sedimentary assemblages preserved in the South Tianshan orogen are dated from 540-520 Ma (Alexeiev et 1365 al., 2020; Safonova et al., 2016), suggesting that ocean basin formation between Tarim and Krygyz Middle 1366 Tianshan begins in the Early-Middle Cambrian. Further north, the relationship between the Kryguz North 1367 Tianshan and Chu-Yili is also reasonably well established (e.g. Windley et al., 2007; Xiao et al., 2013). 1368 Late Ediacaran-Early Cambrian magmatism preserved in Chu-Yili and North Tianshan (Alexeiev et al., 1369 2011; Degtyarev et al., 2017; Kroner et al., 2007) is interpreted to represent development of multiple 1370 contemporaneous arcs (e.g. Alexeiev et al., 2020). The Ordovician-aged sutures between Chu-Yili and 1371 North and Central Tianshan (Windley et al., 2007) are defined by ophiolitic slithers, implying an ocean 1372 basin (or a back-arc) existed between these terranes. We infer that in the late Neoproterozoic to Early 1373 Cambrian, the Kazakh and Tianshan terranes that accreted outboard of India-South China were fragmented 1374 and rifted off this margin forming a collage (not dissimilar to modern southeast Asia, or the NE Pacific in 1375 the Mesozoic, e.g. Sigloch and Mihalynuk (2013) that eventually re-assembled in the Ordovician. We 1376 model the time of fragmentation at $550 \mathrm{Ma}$, because this is the time of collision between India and Congo 1377 along the East African Orogen, so we infer that subduction relocated outboard of the northern margin.

1379 Palaeomagnetic data from South China do not permit a fixed fit between South China and Gondwana for 1380 the early Palaeozoic. The data do, however, permit a close spatial relationship between them $(<1000 \mathrm{~km})$. 1381 Palaeomagnetic data from South China suggest it moved from mid to lower latitudes between the Cambrian 1382 and Devonian (Domeier, 2018; Han et al., 2015). Furthermore, shallow marine faunal data and detrital 1383 zircon arrays suggest that between the Cambrian and Devonian, South China shifted from an Indian1384 Himalayan-Iran affinity (Burrett et al., 1990) to Sibumasu-Australian affinity (Cocks and Fortey, 1997; 1385 Metcalfe, 2013, 2011), broadly consistent of the positions necessary to fit the palaeomagnetic data. Rift 1386 sequences in South China and in northern India (Himalayan terranes) are similar, but diverge strongly after 1387 the early Cambrian (Jiang et al., 2003), providing some kinematic support for invoking for relative motion 1388 between South China and Gondwana. The Sanya Block of Hainan Island (Fig. 15f) is linked through detrital 1389 zircon provenance and middle Cambrian trilobites to western Australia and Antarctica rather than South 
1390 China in the Neoproterozoic (Cawood et al., 2018b; Xu et al., 2014). The presence of Early Ordovician 1391 trilobites in the Sanya block also common to South China and Australia (Torsvik and Cocks, 2009) support 1392 a close relationship between the three domains by this time (Cawood et al., 2018b). A late Cambrian1393 Ordovician (520-450 Ma) metabasaltic arc assemblage in Hainan Island (Xu et al., 2008, 2007) is 1394 interpreted to be the northerly extension of the Kungaan Orogen that sutured Australia-Antarctica and India 1395 (e.g. Xu et al., 2014). We introduce divergent motion between Gondwana and South China at $550 \mathrm{Ma}$, 1396 coinciding with the rift-to-drift sequences of Jiang et al. (2003). This divergent motion moves South China 1397 from a position outboard of Northern India at $550 \mathrm{Ma}$ to one that is slightly further east and adjacent to 1398 western Australian at $500 \mathrm{Ma}$, accounting for the arc assemblage in Hainan as well as similar faunal 1399 patterns. 


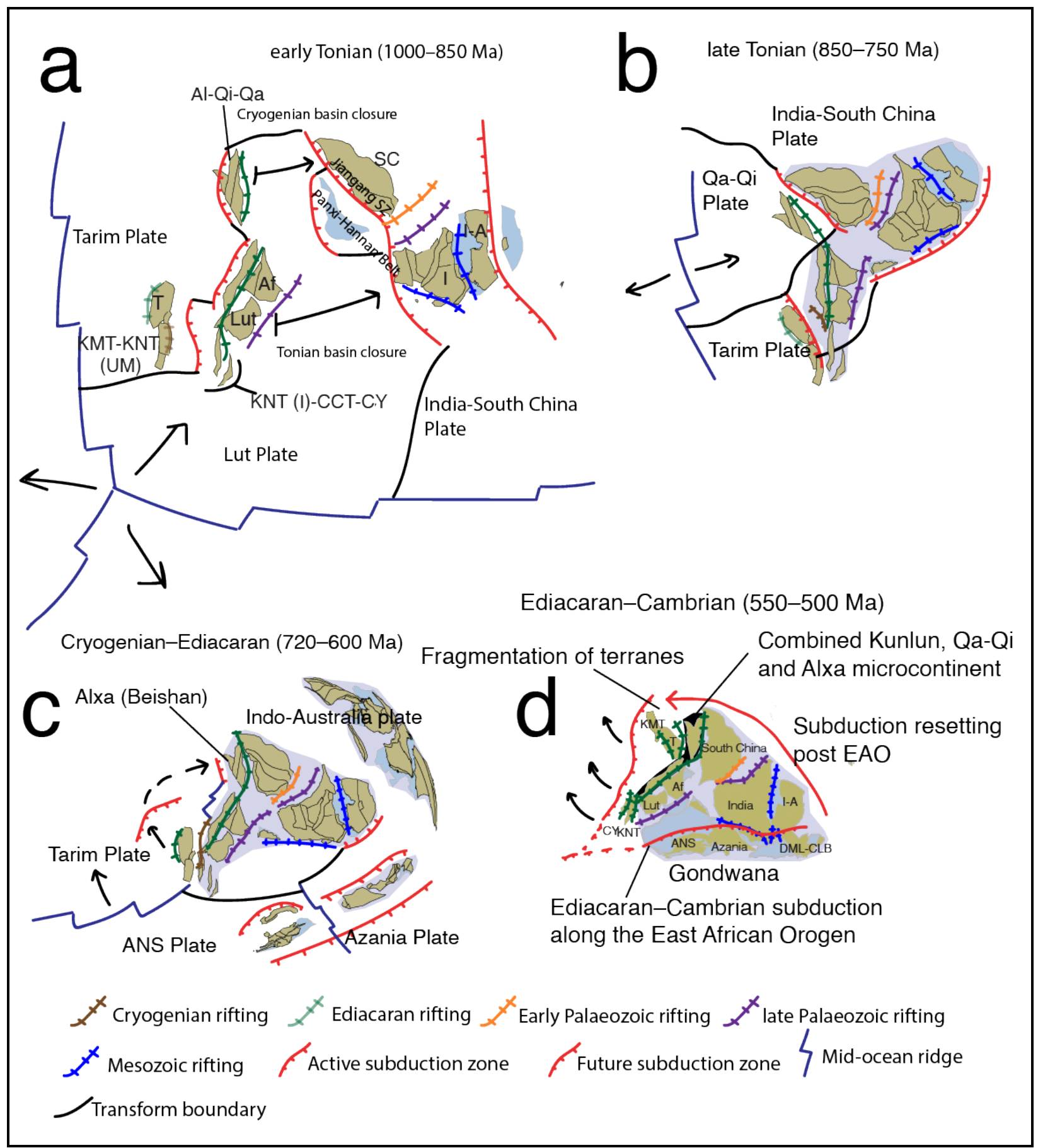


Figure 16

Schematic of our model for India-South China at key time steps, showing accretion of the Yangtze Craton and numerous smaller terranes and blocks to a large, Tonian subduction zone outboard of the northwestern India and the northern margin of South China and their subsequent fragmentation and rifting off during the Ediacaran-Early Cambrian. (a) early Tonian; (b) late Tonian; (c) Cryogenian-Ediacaran, note if the model were adopted to fit the cluster of three palaeomagnetic poles from Tarim then collision would be at ca. $650 \mathrm{Ma}$, and; (d) Ediacaran-Cambrian. Af, Afghanistan; Al-Qi-Qa, Alxa, Qilian, Qaidam; ANS, Arabian Nubian Shield; CY, Chu Yili; DML-CLB, Dronning Maud Land-Coats Land Block; EAO, East African Orogen; I, India; I-A, Indo-Antarctica; KMT (I/UM), Krygyz Middle Tianshan (Issendonian/Ulutau-Moyunkum); KNT (I/UM), Krygyz North Tianshan (Issendonian/UlutauMoyunkum); SC, South China; T, Tarim.

\subsubsection{ANS-Azania-TOAST}

1402 We suggest that, to a first order, the central Arabian-Nubian Shield (ANS) accreted on the kernel of Azania

1403 and formed a semi-continuous archipelago outboard of the eastern margins of the Congo Craton and Sahara

1404 Metacraton (SM) (Fig. 17; Collins and Pisarevsky, 2005; Merdith et al., 2017a). Geological details and a

1405 regional plate model of the accretion of the ANS and Azania are adopted from Collins et al. (in revision),

1406 Blades et al. (2019a) and Johnson et al. (2011), though here we extend Azania to the south by attaching 1407 portions of the Tonian Aged Ocean Arc Super Terrane (TOAST_Jacobs et al. (2017, 2015)). The similarity

1408 in ages, petrology of rocks and $\delta^{18} \mathrm{O}$ from zircons between the Dabolava Suite in Madagascar (Archibald et 1409 al., 2018) and TOAST (Jacobs et al., 2017, 2015; Wang et al., 2020) suggest a similar tectonic environment.

1410 As the southern tip of Azania is reconstructed to be adjacent to the location of the TOAST terrane in 1411 Gondwana, at the nexus between the East African Orogen and the Pinjarra/Kuunga Orogen, there is also a

1412 strong palaeogeographic argument for attaching TOAST to Azania, as their Rodinian reconstructed position 1413 requires no alteration for their position in Gondwana (Fig. 17b). 


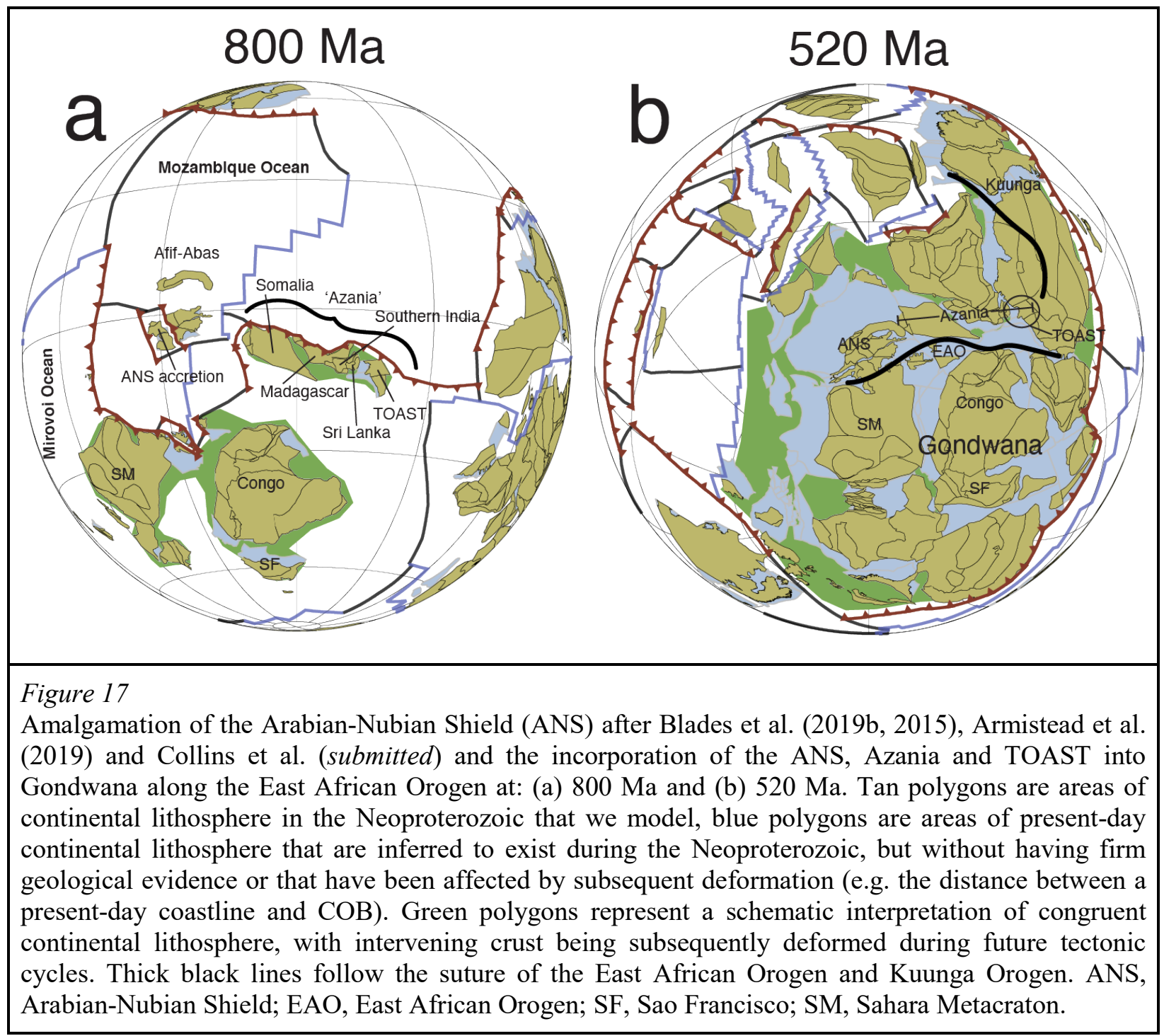

\subsubsection{Hoggar, Borborema, Avalonia and Ganderia}

1417 The Hoggar Block is preserved between the Sahara Metacraton (SM) and the West African Craton (WAC)

1418 in northwest Africa and records a long Neoproterozoic history of accretion of island arcs and continental 1419 ribbons. The model incorporated here is based on fieldwork by Caby et al. (1989), Black et al. (1994) and 1420 Liégeois et al. (1994) and involves three main constituents of present-day Hoggar (from west to east): 1421 IOGU-IGU, LATEA and the Aïr Block (Fig. 18a, b).

1423 The broad tectonic framework of the Hoggar block is an accretionary margin consisting of at least 23 1424 individual terranes that were slowly compressed between two large tectonic units - the WAC and the SM1425 as Gondwana amalgamated. The Aïr block, preserved in the east, is an amalgamation of three closely related 1426 terranes: the Aouzegueur, Barghot and Assodé-Issalane terranes. The first two terranes accreted onto the 
1427 margin of the SM by $650 \mathrm{Ma}$, with the Aouzegueur terrane preserving a tonalite-trondhjemite-granodiorite

1428 (TTG) suite dated at ca. $730 \mathrm{Ma}$ and the Barghot terrane recording calc-alkaline granitoids from ca. 730 to

$1429660 \mathrm{Ma}$, with a post nappe pluton preserving a U-Pb zircon age of $664 \pm 8 \mathrm{Ma}$, interpreted to provide a

1430 minimum age for deformation (Liégeois et al., 1994). Both these terranes were metamorphosed to

1431 greenschist or amphibolite facies and were cut by east-verging thrusts. In contrast, the Assodé-Issalane

1432 terranes exhibit younger magmatism (ca. 640-580 Ma) and amphibolite-facies metamorphism. They are

1433 thrust east over the Barghot terrane. Both Black et al. (1994) and Liégeois et al. (1994) suggest that the

1434 Aouzegueur terrane collided first with the SM, followed by the Barghot terrane, which is positioned slightly

1435 further south than the former, through an east-dipping subduction zone underneath the two terranes (Fig.

1436 18). Following collision, the Assodé-Issalane terrane (which until this time we position slightly west of the

1437 former terranes) was thrust above of the Barghot terrane in response to the closure of the ocean between

1438 the WAC and the SM. Our reconstruction implies that this motion was predominantly transpressive, along

1439 the dextral Raghane shear zone with plutons dating from ca. 630 to $580 \mathrm{Ma}$ (Liégeois et al., 1994).

Further west from the Aïr block in central Hoggar, the LATEA terranes (Laouni, Azrou-n-Fad, Tefedest and Egéré-Aleksod) all consist of Archaean to Palaeoproterozoic basement, but preserve no

1443 Mesoproterozoic or early Neoproterozoic rocks. LATEA was a passive cratonic unit for most of the

1444 Neoproterozoic and acted as a nucleus for the accretion of juvenile terranes. The earliest Neoproterozoic 1445 activity is the accretion of the ca. 900 Ma juvenile Iskel island arc to the western margin of LATEA, with 1446 subduction inferred to be west dipping away from LATEA (Liégeois et al., 2003). The protolith of an 1447 eclogitic unit, currently preserved along the shear zone delineating the Iskel arc and LATEA, is dated to ca. 1448870 to $850 \mathrm{Ma}$ by U-Pb dating from zircons extracted from syn-to-late kinematic plutons (Caby et al., 1449 1982). The combined In-Ouzzal and Iforas granulite units (IOGU/UGI), which are Palaeoproterozoic 1450 continental ribbons, preserve few Tonian rocks. From ca. 700 to 640 Ma magmatism is recorded throughout 1451 the entire region, suggesting that subduction occurred along both margins of the terranes (Caby, 2003) (Fig. $145218 \mathrm{~d}$, e). At $630 \mathrm{Ma}$, collision between the IOGU/UGI terranes and the LATEA block occurred, forming the 1453 combined present-day central-western Hoggar region.

1455 The final tectonic events of this area involve a two-step amalgamation process of Western and Central 1456 Hoggar (i.e. IOGU/UGI and LATEA) to the Aïr Shield and SM, and the collision between this landmass 1457 (Hoggar and the SM) and the WAC, where collisional deformation is preserved in the Pharusian and 1458 Dahoymede belts (Merdith et al., 2017a) (Fig. 18f, g). Here, subduction is inferred to have occurred away 1459 from the WAC (i.e. underneath Hoggar) due to the absence of magmatic rocks preserved on the WAC. 1460 Continual dextral deformation is preserved throughout Hoggar until ca. 530 Ma, suggesting that there was 
1461 still relative motion until the Cambrian (Liégeois et al., 2003; Paquette et al., 1998). The major regime of 1462 the Hoggar block between the Ediacaran and early Cambrian was transpressive, resulting in extensive 1463 faulting and upwelling of the asthenosphere; causing partial melting of lower Archaean crust in some areas 1464 (Hadj-Kaddour et al., 1998). We interpret the final amalgamation of Hoggar to occur at ca. 580 Ma, as this 1465 is the age of the syntectonic, deformed plutons found among the shear zones that bind the SM and the WAC. 1466 Here, a suite of ages include: $\mathrm{Rb}-\mathrm{Sr}$ whole rock ages from dykes affected by the transpressive event yield 1467 an age of 592 $\pm 6 \mathrm{Ma}$ (Hadj-Kaddour et al., 1998); a 583 $\pm 7 \mathrm{Ma}$ U-Pb age on zircons extracted from the syn1468 to-late tectonic, elongated Imezzarene pluton (Lapique et al., 1986); a 594 $\pm 4 \mathrm{Ma}$ and $593 \pm 17 \mathrm{Ma}$ U-Pb age 1469 of zircon extracted from the Ohergehem and Adaf plutons, respectively (Henry et al., 2009). Fezaa et al. 1470 (2010) identified younger (ca. 575-555 Ma) deformation in the Murzoq area of Hoggar, however, they 1471 suggested that it was unrelated to the main convergence between WAC and SM. 


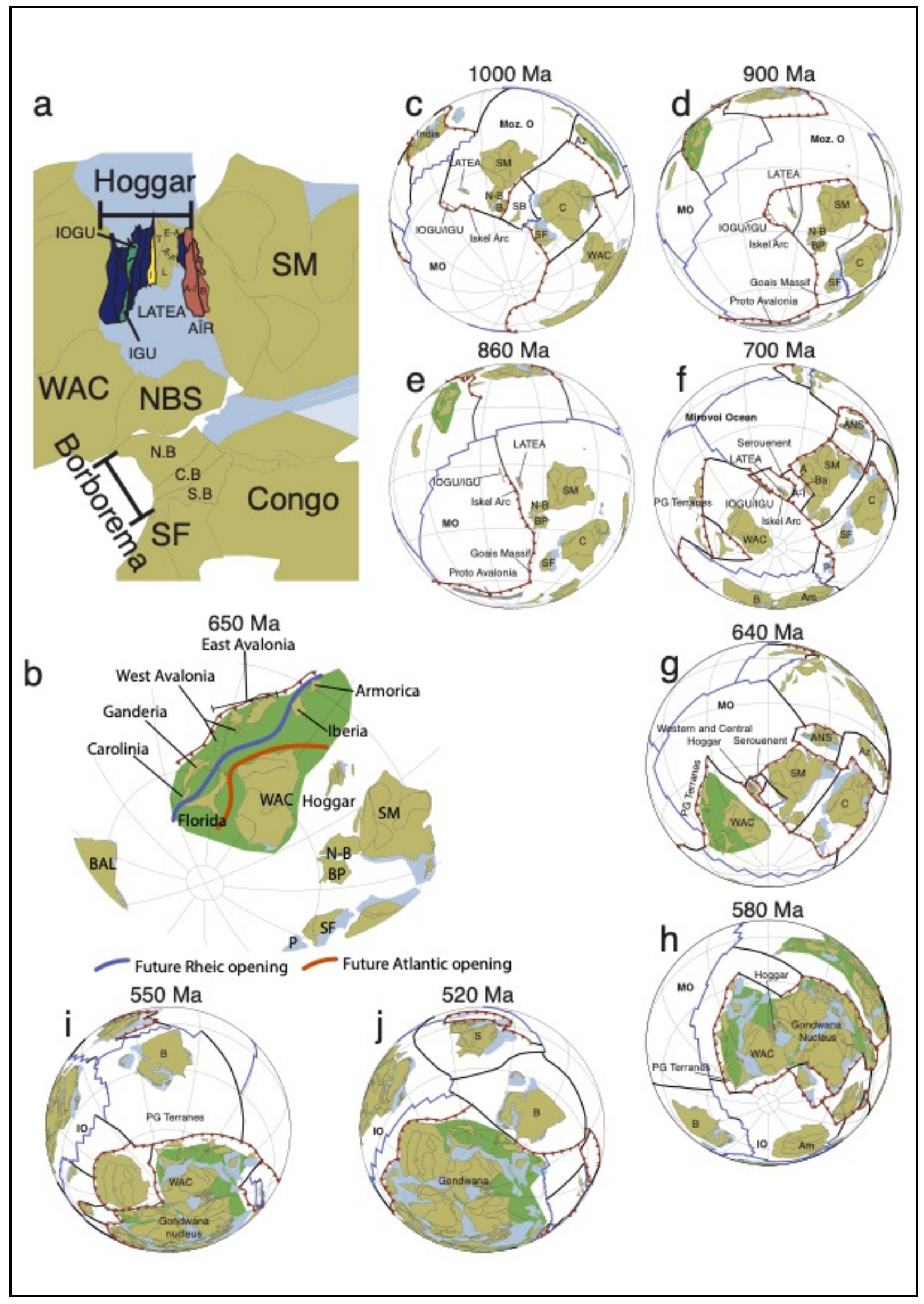


Figure 18

Amalgamation of Hoggar after Caby et al. (1989), Black et al. (1994) and Liégeois et al. (1994), Borborema and Peri-Gondwanan terranes after Nance et al. (2008) at key time slices. (a) map of key terranes in a reconstructed Gondwana (dark blue terranes are oceanic terranes); (b) map of reconstructed Peri-Gondwanan terranes at $650 \mathrm{Ma}$; (c) $1000 \mathrm{Ma}$; (d) $900 \mathrm{Ma}$; (e) $860 \mathrm{Ma}$; (f) $700 \mathrm{Ma}$; (g) $640 \mathrm{Ma}$; (h) $580 \mathrm{Ma}$; (i) $550 \mathrm{Ma}$ and (j) $520 \mathrm{Ma}$. Tan polygons are areas of continental lithosphere in the Neoproterozoic that we model, blue polygons are areas of present-day continental lithosphere that are inferred to exist during the Neoproterozoic, but without having firm geological evidence or that have been affected by subsequent deformation (e.g. the distance between a present-day coastline and COB). Green polygons represent a schematic interpretation of congruent continental lithosphere, with intervening crust being subsequently deformed during future tectonic cycles A, Aouzegueur; A-I, Assodé-Issalane; Am, Amazonia; ANS, Arabian-Nubian Shield; B, Baltica; BP, Borborema Province; C, Congo; C-B, Central Borborema; IGU, Iforas granulite unit; IOGU, In Ouzzal granulite unit; IO, Iapetus Ocean; LATEA, Laouni, Azrou-n-Fad, Tefedest and Egéré-Aleksod terranes; MO, Mirovoi Ocean; Moz. O, Mozambique ocean; N-B, Niger-Benin Block; P, Paranapanema; PG, Peri-Gondwanan terranes; S-B, Southern Borborema; SF, Sao Francisco; SM, Sahara Metacraton; WAC, West African Craton.

1474 The Borborema block sits between Congo-SF and the Nigeria-Benin Shield in a reconstructed Gondwana 1475 (Fig. 18a). This small block consists of Archaean-Proterozoic basement that was strongly reworked and 1476 deformed during the Gondwana amalgamation events between Africa and Amazonia (dos Santos et al., 1477 2010). Magmatism in the Transversal Domain of Central Borborema is thought to represent a local, early

1478 Tonian orogeny called the Cariri Velhos Orogeny (da Silva Filho et al., 2002; dos Santos et al., 2010). Late

1479 Stenian rift deposits are preserved in the Cariri Velhos belt, suggesting that the Pernambuco-Alagoas 1480 domain (PEAL) (the crystalline basement of Southern Borborema) originally rifted from this margin 1481 (Guimarães et al., 2012), before the ocean inverted and closed. Our model places the Northern and 1482 Transversal Domains of Borborema fixed to the Nigeria-Benin-SM blocks, while the PEAL closed the 1483 small Stenian aged relict ocean basin as it collided with the northern and central Borborema provinces by 1484 ca. $920 \mathrm{Ma}$ (Caxito et al., 2014a), forming the Cariri Velhos Orogen. An ocean basin remained on the 1485 southern margin of PEAL until the Ediacaran, as the final collision between Borborema and SF did not 1486 occur until this time forming the Sergipano belt, which preserves relict oceanic crust (e.g. Caxito et al., 1487 2014b; Ganade de Araujo et al., 2014) (e.g. Fig. 9). To accommodate the Tonian closure, while maintaining 1488 an open ocean basin to the south of PEAL, we follow Caxito et al. (2014a, 2016) who suggested that the 1489 synchronous rifting and aulacogen formation preserved in SF (Pedrosa-Soares et al., 2001), which in our 1490 model is reconstructed to be adjacent to PEAL, are relicts of the divergent motion necessary to achieve this.

1492 The Avalonian terranes, currently preserved in the east coast of modern day North American and western 1493 Europe, have a well-documented Neoproterozoic history (e.g. Murphy and Nance, 1989). The Avalonian 1494 terrane is interpreted to be underlain by ca. $1.0 \mathrm{Ga}$ juvenile basement on the basis of $1.3-0.8 \mathrm{Ga} \mathrm{Sm}-\mathrm{Nd}$ 1495 depleted mantle model ages in in younger Neoproterozoic rocks (Murphy et al., 2000; Thorogood, 1990). 
1496 These younger rocks consist of magmatic gneiss and plutonic complexes, along with tuffs, pelitic schists 1497 and quartzites. U-Pb ages of the complexes and tuffs range from ca. 750-650 Ma (Bevier et al., 1993; Doig 1498 et al., 1993; Keppie and Dostal, 1998; Krogh et al., 1988; O’Brien et al., 2001) and detrital zircons from 1499 the (meta-)sedimentary rocks suggest they were sourced from a juvenile arc (metapelites, Murphy, 2002) 1500 and a cratonic source (quartzite), typically inferred to be Amazonia or the WAC (Nance et al., 2008). This 1501 magmatism is followed by amphibolite-granulite metamorphism from 660-630 Ma (Keppie et al., 1998; 1502 Strachan et al., 2007). Younger magmatism (ca. 640-550 Ma) is more voluminous and includes abundant 1503 arc derived volcanic, plutonic complexes and coeval volcanic-sedimentary successions (Bevier et al., 1993; 1504 Compston et al., 2002; Doig et al., 1993; Nance et al., 2008; O’Brien et al., 2001; White et al., 2020).

1505 Subduction does not continue into the Cambrian, instead a clastic platform and transition to rift environment 1506 begins to form, culminating in the opening of the Rheic Ocean (Domeier, 2016; Nance et al., 2008; Nance 1507 and Linnemann, 2008).

To a first order, Ganderia and Carolina, both preserved in North America, record a similar Neoproterozoic history to Avalonia, differing predominantly in that key metamorphic and magmatic events are ca. 30 40 Ma younger than in Avalonia (Hibbard et al., 2007; Nance et al., 2008; van Staal et al., 2012). Depleted mantle model ages from Sm-Nd isotopes also hint at the presence of ca. 1.2-0.8 Ga juvenile crust in 1513 Carolina (Hibbard et al., 2007). However, the principal period of magmatism in both Ganderia and Carolina 1514 is preserved from 650 to $580 \mathrm{Ma}$ and is inferred to have occurred in an ocean-arc environment (Hibbard et 1515 al., 2007). Metamorphism, up to eclogite facies, occurs at the end of this period and continues into the 1516 earliest Cambrian (580-540 Ma) (Barker et al., 1998; Shervais et al., 2003). Younger magmatism (to ca. $1517520 \mathrm{Ma}$, White et al., 2002) linked to the rifting and opening of the Rheic Ocean, is only preserved in 1518 Ganderia (Hibbard et al., 2007). Finally, the Suwannee terrane of Florida is linked tectonically to both the 1519 West African Craton and Amazonia throughout the Neoproterozoic (Dallmeyer, 1989), lacking the 1520 Neoproterozoic arc development preserved in Avalonia, Ganderia and Carolina. Instead, 550 Ma calc1521 alkaline volcanic rocks are inferred to represent the remnants of a continental arc (Heatherington et al., 1522 1996).

1524 We follow the model of Nance et al. (2008) and Murphy et al. (2004) for the Neoproterozoic evolution of 1525 these terranes. An early Tonian (1-0.8 Ga) oceanic arc outboard of Baltica-Amazonia-WAC dipping under 1526 the Rodinian plate, formed the earliest portions of crust preserved in these terranes (Fig. 18c-e). The relative 1527 positioning of the terranes follows that of DOM16, with East Avalonia most easterly (Fig. 18b), then West 1528 Avalonia, and Ganderia and Carolina furthest west, with Ganderia sitting oceanward of Carolina. This 1529 arrangement follows the same logic outlined in Section 5.2.2, as by maintaining this relative positioning 
we avoid having to laterally re-organise the terranes during the Palaeozoic. This is slightly different from the positioning in Nance et al. (2008), who model West Avalonia more easterly (relative to a fixed WAC) than East Avalonia and invoke wrench-tectonics to laterally translate the terranes. Nonetheless, at ca. 750 Ma this subduction polarity reversed and the adjacent ocean basin between WAC-Baltica began to subduct underneath Avalonia. We model Ganderia and Carolina slightly further away from the active subduction front-behind Western Avalonia, to account for their lack of Cryogenian magmatism. This arc front collided with WAC at ca. $650 \mathrm{Ma}$ when the subduction ceased and reset outboard of the now amalgamated Avalonian-WAC continent as a continental arc (Fig. 18f, g). This subduction continued until the Cambrian when the area transitioned into a rift environment when the Rheic Ocean opened.

This last phase our model is preliminary and needs further development, though we hope that it provides a framework that can assist with testing alternative scenarios. By fitting the latitude of the ca. 520-500 Ma poles of Baltica (Section 5.2.1), subduction must consume most of the relic ocean basin immediately north of the Avalonian margin of Gondwana between 550 and 520 Ma. The magmatism in Ganderia easily accounts for this, however Baltica needs to be further east at $520 \mathrm{Ma}$, otherwise it must undergo $4000 \mathrm{~km}$ of dextral motion (relative to Gondwana) to allow for the initial stages of the Rheic Ocean opening at ca $500 \mathrm{Ma}$ (e.g. Domeier, 2016; von Raumer and Stampfli, 2008), which we suggest is not a reasonable scenario. As such, our model places a subduction zone slightly outboard of Avalonia, but acknowledge that this is a simplification that needs further refinement.

\section{Plate Model}

Having discussed the motions of the evolution of continental configurations in previous sections, here we

1553 discuss the more speculative elements of the reconstruction - the oceanic plates and plate boundaries. For

1554 further in-depth discussion of the continental portions of the model, in particular the major Gondwana

1555 forming sutures and evolution of the post-Cambrian world, we point readers to the studies that produced 1556 the base models used here (MER17, DOM16/18, YOU19, DT14). We also provide in our supplementary 1557 material the associated plate model files (SM2), as well we a tectonic summary of seafloor production and 1558 consumption rates, mid-ocean ridge length and subduction zone length (SM3).

\subsection{Synthetic ocean plates}

1562 The construction of synthetic ocean plates is required to maintain tectonic congruency (Section 2.7) but, 1563 with few exceptions (e.g. ophiolites), there is no direct evidence of the configuration or tectonic parameters 
1564 (e.g. spreading rate, asymmetry) of oceanic crust for the pre-Mesozoic due to the constant subduction of 1565 oceanic lithosphere. However, we know that oceanic crust typical of present-day (i.e. MORB) did exist in 1566 the Palaeozoic and Neoproterozoic, as evidenced by ophiolitic remains preserved in orogens (Furnes et al., 1567 2014). We therefore use one key assumption when constructing oceanic plates: we assume that the 1568 production (rate of motion, orthogonal spreading etc.) and subduction of oceanic crust in the 1569 Neoproterozoic was fundamentally similar to the Cenozoic. We note that this may not be a valid assumption 1570 for the early Neoproterozoic, since abundant ophiolite preservation only occurs after Rodinia breakup 1571 (Stern and Miller, 2018) and pre-1 Ga ophiolites suggest thicker oceanic crust (Moores, 2002) which, along 1572 with secular changes in Earth's heat loss (Brown et al., 2020b) could have an influence on spreading and 1573 subduction dynamics. Nonetheless, we maintain that if available palaeomagnetic and geological data can 1574 be reconciled within a uniformitarian framework of oceanic crust production and destruction, then our 1575 model becomes a useful reference model for future models that explore alternative hypotheses. 1576 Measurements of seafloor production, crustal consumption, ridge length and subduction zone length are 1577 provided in the supplementary material.

\subsubsection{Early Tonian until Rodinia breakup (1000-750 Ma)}

In our model, three prominent ocean basins existed in the early Tonian: the Mirovoi Ocean (McMenamin et al., 1990; Meert and Lieberman, 2008), the Mawson Sea (Meert, 2003; Meert and Lieberman, 2008) and the Mozambique Ocean (Fig. 8) (Collins et al., 2003; Collins and Pisarevsky, 2005). These ocean basins have been defined previously in the same context as they appear in our model, however, given differences between our model and the original publications, the geographical boundaries of each ocean are slightly different.

We define the Mirovoi Ocean as the large ocean bordering Rodinia in its west and India-South China and the Sahara Metacraton in the north east and south east respectively. The Mirovoi is the largest and most prominent ocean basin for the Neoproterozoic in our model, existing until ca. 520 Ma with the opening of the Proto-Tethyan Ocean and Ran Sea (Fig. 9, Hartz and Torsvik, 2002). It is (conceptually) equivalent to

1592 the external Panthalassic and Pacific oceans of the Phanerozoic, as it consists almost entirely of oceanic 1593 lithosphere and is ringed by subduction for the majority of its existence. At $1000 \mathrm{Ma}$, we model a triple 1594 junction spreading ridge located roughly in the centre of the ocean basin. The triple junction provides three 1595 directions of spreading to account for convergence in three areas: (i) the closure of the ocean basin 1596 separating India-South China from Tarim, Qaidam-Qilian, Lut, Afghanistan, Kunlun and Tarim (this study); 1597 (ii) the Taimyr subduction zone outboard of northern Siberia (Metelkin et al., 2012; Vernikovsky et al., 
1598 2004) and the Valhalla Orogen outboard of Greenland (Cawood et al., 2010), and; (iii) the Proto-Avalonian-

1599 Cadomian subduction zone outboard of Baltica and Amazonia (Murphy et al., 2000) that extends

1600 northwards to Sao Francisco and further north where it is preserved in the Iskel Island Arc of Hoggar

1601 (Liégeois et al., 2003).

1602

1603 The spreading arms of the triple junction span north, east-southeast and southwest. The northern arm 1604 separates Siberia and the India-China accretionary zone and extends partway into the Mawson Sea. The 1605 east-southeastern arm extends towards India, where we connect it via a transform fault to the mid-ocean 1606 ridge in the Mozambique Ocean. The southwestern arm intersects the Proto-Avalonian subduction zone. 1607 We model this configuration (triple junction) as being stable through the early Tonian until ca. 870-850 1608 Ma, where a plate-reorganisation event occurs. We link this organisation to a change in kinematics of 1609 Rodinia, suggested through palaeomagnetic data. At this time, palaeomagnetic data from the Baltica 1610 (Walderhaug et al., 2007) suggest that Rodinia had drifted to southerly latitudes, before returning to 1611 equatorial latitudes by ca. $750 \mathrm{Ma}$ (Eyster et al., 2019). MER17 modelled significant relative dextral motion 1612 between Congo-SF-Azania and Rodinia during this time $(870-750 \mathrm{Ma})$ as well, as suggested by 1613 palaeomagnetic data (Evans et al., 2016). Geological data from Congo-Azania also supports the rotation, 1614 with onset of sedimentation interpreted to be a rift event in the Damara region (Armstrong et al., 2005; 1615 McGee et al., 2012) and the onset of a massive subduction system outboard of Azania (Archibald et al., 1616 2017; Handke et al., 1999). During this transition (850-800 Ma), we model the Mirovoi Ocean as a single 1617 spreading ridge, orientated sub-parallel to the north-facing arm in the original triple junction, extending 1618 northwards toward Siberia and intersecting an oceanic arc outboard of Baltica.

1620 For the Tonian, until $750 \mathrm{Ma}$, the South China-India continent moved to polar latitudes on the north-eastern 1621 side of the Mirovoi Ocean basin. Comparably, Siberia started dextral motion relative to Rodinia, from a 1622 position near Australia-North China to one near Greenland (Pisarevsky et al., 2013). To account for this 1623 motion, alongside ongoing subduction in the Taimyr region of Siberia, we have extended the spreading 1624 ridge from the Mozambique Ocean into the Mirovoi Ocean (running E-W) and have a northern arm 1625 accounting for divergence between Tarim and the Taimyr subduction zone. This interpretation necessitates 1626 the presence of a triple junction, with a third ridge arm intersecting the subduction zone outboard of Baltica, 1627 similar to the configuration at the start of the Tonian.

1629 The Mawson Sea is defined as the ocean basin between Australia and India-South China that closed with 1630 the amalgamation of Gondwana (Meert, 2003). In the early Tonian, this basin is large in our model, 1631 necessitated by MER17s removal of India-South China from Rodinia. The large size is because relative 
1632 longitude prevents India-South China (at this point in time travelling north from the equator) from being 1633 any closer to Australia, as Azania occupied the same latitude as India and lay between India and Australia. 1634 We model a single spreading ridge in the centre of the ocean basin, accounting for the subduction on the 1635 India-South China margin as suggested in the Eastern Ghats of India and accretion of the Ruker Terrane to 1636 Indo-Antarctica (e.g. Corvino et al., 2008; Liu et al., 2017). In South China, this subduction is more sparse, 1637 but recent work has suggested that part of present-day Vietnam is associated with the southwestern Yangtze 1638 craton (Minh et al., 2020) and could record the late Tonian portion of a subduction system and be the focus 1639 of future work. At 930 Ma the spreading direction of the ridge changes, to compensate for the southerly 1640 drift of Rodinia. The change in spreading direction coincides with the docking of North China-Australia1641 Antarctica with Laurentia as the final amalgamation event of Rodinia (Mulder et al., 2018b). At this time 1642 we model subduction initiating outboard of Australia (against Lhasa, (e.g. Guynn et al., 2006) and into the 1643 ocean outboard of Antarctica further south. Preserved evidence of subduction here is sparse due to ice cover 1644 in Antarctica. However, this area of the ocean (just outboard of the western margin of the Mawson craton) 1645 is positioned at the centre of Antarctica in the nexus between the TOAST terrane and Mawson craton, so it 1646 could be possible some arcs are preserved in Antarctica. Further south, this subduction zone transitions into 1647 a transform boundary and separates relative motion between Azania-Congo and Rodinia between $930 \mathrm{Ma}$ 1648 and $850 \mathrm{Ma}$. We model continual spreading in the Mawson Sea until $850 \mathrm{Ma}$, at which time the ocean basin 1649 begins to close and we do not model an active ridge. By 750 Ma the Mawson Sea is extremely narrow, with 1650 only 2500-3500 km of ocean basin separating Australia and India. A narrow ocean basin is supported 1651 geologically by the strong evidence suggesting that a large sinistral shear zone was present outboard of 1652 western Australia and Antarctica during the Cryogenian and Ediacaran, suggesting that there was close 1653 proximity without collision between Australia-Antarctica and another continent (Collins, 2003; Fitzsimons, 1654 2003; Halpin et al., 2017; Merdith et al., 2017b; Powell and Pisarevsky, 2002).

1656 The Mozambique Ocean is described as the ocean that closed with the collision of India and Congo along 1657 the East African Orogen reacted to Gondwana amalgamation during the Cryogenian and Ediacaran (e.g. 1658 Collins and Pisarevsky, 2005). For the sake of continuity, we refer to this ocean as the Mozambique in the 1659 Tonian as well. A small ocean (in our model, roughly equivalent in size to the Tasman Sea between 1660 Australia and New Zealand), termed 'Neomozambique Ocean' also closed with the formation of the East 1661 African Orogen, however this ocean was located between ANS-Azania-TOAST and Congo (Fig. 8).

1663 Geographically, the location of the Mozambique ocean is difficult to determine in the early Tonian due to 1664 overlapping latitudes between Azania and India (they are separated longitudinally by $\sim 120^{\circ}$ in our model). 1665 In our model there is no spreading in this ocean basin at this time, because Congo-Azania was latitudinally 
stable while India-South China moves towards the North Pole on a different longitude, accounted for by

1667 spreading in the Mirovoi Ocean. The spreading ridge in the Mawson Sea at ca. 900 Ma extends sufficiently

1668 south so that the ocean lithosphere generated here is subducted during closure of the Mozambique Ocean.

1669 We model active spreading in a clearly defined Mozambique Ocean beginning at 850 Ma, by which time

1670 India-South China had a similar longitude to Azania-Congo, making it easier to delineate the geographical

1671 extent of the ocean distinct from the Mawson Sea. Between 820 and 750 Ma the ocean basin closes rapidly,

1672 in order to fit palaeomagnetic constraints at $750 \mathrm{Ma}$ that show India at $\sim 60^{\circ} \mathrm{N}$ (Gregory et al., 2009; Torsvik

1673 et al., 2001) and Congo at $15^{\circ} \mathrm{S}$ (Meert et al., 1995) (placing Azania at the equator).

At $800 \mathrm{Ma}$, we model the birth of the Pacific/Panthalassic Ocean, here defined as the ocean basin separating

1676 Laurentia from North China, Australia and Antarctica, which most likely opened as Rodinia broke-up

1677 (although terrane migration across this ocean basin cannot be ruled out, e.g. Mulder et al. (2020). We note

1678 here that the pre-Mesozoic Pacific Ocean is already universally referred to as the Panthalassic Ocean.

1679 Consequently, we refer to the ocean separating North China-Australia-Antarctica and Laurentia between

1680 Rodinia and Gondwana times (ca. 800-520 Ma) as the proto-Pacific Ocean, the ocean surrounding

1681 Gondwana as the Panthalassic Ocean ('Panthalassa', ca. 520-200 Ma) and the ocean that has existed from

$1682200 \mathrm{Ma}$ to present-day as the Pacific Ocean, noting that all three of these oceans essentially refer to the

1683 same ocean basin (in a geographical sense) that existed between North China-Australia-Antarctica and

1684 Laurentia. From 800 to $720 \mathrm{Ma}$ we have a single ridge system separating Australia-Antarctica and

1685 Laurentia. This ridge produces a highly angular divergence, with spreading rates faster towards northern

1686 Australia and Canada than in Antarctica, resulting in a wider ocean basin in the north and narrower in the

1687 south. These variable spreading rates are required fit the ca. $750 \mathrm{Ma}$ palaeomagnetic data, which require

1688 Australia to be 'upright' (same orientation as present-day) and perpendicular to Laurentia (Wingate and

1689 Giddings, 2000).

By $720 \mathrm{Ma}$, continental motions around the Mirovoi Ocean are latitudinally stable with no polar excursions 1694 thus, the simplest way to account for the necessary subduction is with a stable triple junction. At this time, 1695 we show subduction along the western margin of the Mirovoi Ocean, outboard of Siberia in the Taimyr 1696 region, as well further south outboard of the WAC and Baltica where the Avalonian and Cadomian terranes 1697 were coalescing (Murphy et al., 1999; Murphy and Nance, 1989) and along the northern margin of the 1698 Sahara Metacraton in the east. This latter subduction zone is speculative since there are no known rocks of 1699 this age in the Sahara Metacraton (Blades et al., submitted). The Mirovoi ocean basin does not grow 
1700 appreciably during the Ediacaran due to onset of subduction around its periphery, however, at $590 \mathrm{Ma}$

1701 Baltica begins moving north, resulting in the consumption of the Mirovoi Ocean basin and necessitating a

1702 change in mid-ocean ridge configuration. At this point we model a single ridge parallel to the Gondwanan

1703 margin, from Amazonia in the west towards India in the northeast. This ridge also accommodates the final

1704 motion of India as it collides with Congo. It is difficult to identify when the Mirovoi Ocean ceased to exist,

1705 but by ca. 490 Ma, expansion in the Proto-Tethyan ocean basin outboard of northwest Gondwana (e.g. Fig.

1706 12), as well as the easterly drift of Siberia amalgamates the Siberian subduction zones outboard of North

1707 China and Chu-Yili-Tianshan, probably indicating that the majority of Mirovoi crust produced during the

1708 Cryogenian and Ediacaran has been consumed.

1709

1710 An obvious issue with this discussion on the size of the Mirovoi is the longitudinal uncertainty between the 1711 position of Congo and Laurentia during the Ediacaran. This uncertainty is because the distance between 1712 these two cratons dictates the size of the Adamastor Ocean (between Kalahari and Congo), which grew at 1713 expense of the Mirovoi Ocean. Earliest evidence of subduction in the Damara belt exists from $650 \mathrm{Ma}$, with 1714 final closure occurring at $550 \mathrm{Ma}$. A conservative convergence rate of 40-60 km/Ma (roughly equivalent 1715 to present-day Pacific convergence rates) would make the ocean basin at 4000-6000 km wide, roughly 1716 equivalent to the present-day Atlantic Ocean (this width is similar in our model to that of the Adamastor 1717 Ocean). However, faster divergence during Rodinia breakup would increase the size of this ocean basin, in 1718 turn reducing the size of the Mirovoi Ocean during the Ediacaran, similar to how the size of the modern 1719 Pacific Ocean would become smaller or larger depending on the changing size of the Atlantic Ocean.

1721 The Mawson Sea remains very small in size during the Cryogenian due to the close proximity between 1722 India and Australia-Antarctica. There is no active ridge, instead a transform fault separates the two 1723 continents. There is little evidence of subduction-related magmatism on either cratonic Australia or India 1724 or this time (e.g. Halpin et al., 2017), suggesting the intervening lithosphere that eventually closed with 1725 Gondwana amalgamation could have also involved a more complex scenario of terrane accretion. The 1726 veracity of that statement is strongly dependent on the configuration and relative positioning of other 1727 terranes that are typically reconstructed to the north-western margin of Australia in the late Palaeozoic, such 1728 as Sibumasu and Indochina (Metcalfe, 2011) or other terranes preserved in Antarctica that are speculated 1729 to have rifted off the Indo-Antarctica and accreted to the western margin of the Mawson Craton (Daczko et 1730 al., 2018; Mulder et al., 2019). Neither set of terranes are yet considered explicitly in our model. By 520 1731 Ma Australia-Antarctica is sutured with India, closing any remnants of the Mawson Sea. 
1733 Both the Mozambique and NeoMozambique oceans close orthogonally from 720 to 550 Ma due to the

1734 continual southward motion of India towards Congo-SM. We do not model an active spreading ridge during

1735 this time, as subduction is only preserved on the African side of the collision (Collins and Pisarevsky, 2005).

1736 The presence of an earlier ridge does, however, suggest that at least two ridges (in our model they are

1737 extinct) were subducted during the East African Orogeny.

1738

1739 The Proto-Pacific Ocean grows predominantly longitudinally during the Cryogenian-Cambrian. In our 1740 model, we show separation between Australia-Antarctica-North China and Laurentia using a single ridge 1741 system that propagates southwards, around southern Laurentia to eventually separate the Kalahari Craton 1742 and DML at ca. 700 Ma. We maintain a single ridge system until the Ediacaran, although when Kalahari 1743 begins drifting from Laurentia, we follow Merdith et al. (2017b) in inferring a ridge jump to re-align 1744 spreading between Australia and Laurentia with the incipient ridge separating Kalahari and Laurentia. This 1745 ridge jump also assists with reconciling the necessary motion of Australia to Ediacaran palaeomagnetic 1746 data, which require a $\sim 35-45^{\circ}$ counter-clockwise rotation from its present-day orientation (Schmidt and 1747 Williams, 2010). At $580 \mathrm{Ma}$ we model a triple junction in the Proto-Pacific Ocean that coincides with the 1748 equatorial excursion of Baltica and cessation of triple junction spreading in the Mirovoi Ocean. The arms 1749 of this triple junction intersect sub-perpendicular to subduction outboard of Laurentia, a transform fault 1750 outboard of North China and another transform boundary outboard of Baltica.

1751

1752 Between 500 and $410 \mathrm{Ma}$, we refer to the ocean as the Panthalassic Ocean and for this time interval we 1753 extended the triple junction of YOU19 backwards through DOM16 and DOM18. We found at $500 \mathrm{Ma}$ 1754 when Cuyania rifts off the promontory of Laurentia (Domeier, 2016), that the position of the triple junction 1755 and orientation of the ridges extended backwards from YOU19 was parallel to the direction of spreading 1756 separating Cuyania from Laurentia. While coincidental, given the arbitrary nature of pre-Mesozoic ocean 1757 plates, we find it useful to use the configuration at this time as a transition from the Proto-Pacific Ocean to 1758 the Panthalassic Ocean.

\section{Conclusions}

1762 We present here the first continuous full-plate model from $1 \mathrm{Ga}$ to present-day. The model traces the 1763 kinematic evolution of all cratonic crust and links the Neoproterozoic to the Phanerozoic, encompassing an 1764 entire supercontinent cycle, and enabling quantitative analysis of tectonic features for deep time. We present 1765 the model in a palaeomagnetic reference frame, including a new APWP for Gondwana from 540 to $320 \mathrm{Ma}$ 1766 and a GAPWaP from 320 to 0 Ma. For the Neoproterozoic, the model uses a hybrid hierarchy, where 
1767 relative plate motions are tied to a key plate, forming distinct nodes. This cluster-approach allows for the

1768 model to be iterated, constructed and modified in the future more easily in light of sparse palaeomagnetic

1769 data, but abundant geological data. Our revised Neoproterozoic model incorporates a late amalgamation of

1770 Rodinia with a novel configuration, in particular through the removal of India, South China and Tarim from

1771 the supercontinent. We incorporate major plate re-organisation events at ca. $850 \mathrm{Ma}$ and again at ca. 750-

$1772700 \mathrm{Ma}$, corresponding to the counter-clockwise rotation of Congo-Sao Francisco-Sahara Metacraton

1773 relative to Rodinia and the initial closing of the Mozambique Ocean and coeval opening of the Proto-Pacific

1774 Ocean, respectively. Our model also includes preliminary interpretations of the Neoproterozoic history of 1775 many regional areas, such as terrane amalgamation outboard of India-South China, Hoggar and Avalonia, 1776 that then link coherently with their more established Phanerozoic histories. We reiterate that this model is 1777 a non-unique solution of global palaeogeography and tectonics for the Neoproterozoic but we hope it can 1778 provide a framework on which future studies can build upon. To facilitate this, we include in our 1779 supplementary material (SM3) the tectonic parameters of seafloor production and consumption as extracted 1780 from the model.

1782 Because our model has continuous plate boundaries, it enables a range of new scientific experiments such 1783 as those seeking to link plate boundary processes to other aspects of the Earth system. This includes 1784 experiments related to the biosphere, hydrosphere and atmosphere investigating events surrounding 1785 oxygenation of Earth's atmosphere, Snowball Earth and animal radiation (e.g. (Gernon et al., 2016; 1786 Goddéris et al., 2017; He et al., 2019; Hoffman et al., 1998; Hoffman and Schrag, 2002; Lenton et al., 2016; 1787 Mills et al., 2019) and those studying the deep Earth (e.g. Heron et al., 2020). There are a number of 1788 limitations of this study, in particular, we do not address TPW in this model. Most previous studies looked 1789 at TPW purely from a palaeomagnetic framework, however the incorporation of geological data in the form 1790 of plate boundaries in this model (and others like it) open up opportunities for to analyse whole-lithospheric 1791 motion from other directions (e.g. Tetley et al., 2019).

\section{Acknowledgements}

The authors thank Sergei Pisarevsky for advice on palaeomagnetic data. ASM is currently supported by the Deep Energy Community of the Deep Carbon Observatory and the Richard Lounsbery Foundation. ASM, SEW, RDM and SZ were supported by Australian Research Council grant IH130200012. ASC and MLB are supported by Australian Research Council grants FT120100340 and LP160101353. MGT was supported by European Research Council Grant Agreement 617588 and Agence Nationale de la Recherche 
1801 by an Australian Government Research Training Program Scholarship. SZ was supported by Australian 1802 Research Council grant IH130200012, a University of Sydney Robinson Fellowship. SZ and RDM were 1803 supported by Alfred P. Sloan grants G-2017-9997 and G-2018-11296 through the Deep Carbon 1804 Observatory. JC and RDM were also supported by the AuScope National Collaborative Research 1805 Infrastructure System (NCRIS) program. pyGPlates and GPlates development is funded by the AuScope 1806 National Collaborative Research Infrastructure System (NCRIS) program. The authors are grateful for 1807 thorough reviews by D. J. J. van Hinsbergen, C. Scotese and B. Murphy, all of which greatly improved the 1808 focus and clarity of the manuscript. 
1811

Table 1

\begin{tabular}{|l|l|l|}
\hline Model & Time (Ma) & Scope \\
\hline & & \\
\hline SET12 & $200-0$ & Global \\
\hline DT14 & $410-250$ & Global \\
\hline MUL16 & $230-200$ & Global \\
& & \\
\hline MAT16 & $410-0$ & Global \\
\hline DOM16 & $500-410$ & Gondwana-Laurentia-Baltica \\
\hline MER17 & $1000-520$ & Global \\
\hline DOM18 & $500-410$ & Gondwana-Siberia-China \\
& & \\
\hline YOU19 & $410-0$ & Global \\
\hline MUL19 & $250-0$ & Global \\
\hline This model & $1000-0$ & Global \\
& & \\
\hline
\end{tabular}

Reference Frame Palaeomagnetic Mantle

\begin{tabular}{|l|l}
\hline Palaeomagnetic & Mantle \\
\hline No & Yes
\end{tabular}

Details

LLSVPs

Details

TPW corrected palaeomagnetic
Hotspot motion (100-0 Ma).

PWW corrected mantle reference from 410-250 Ma.

No assumption.

Hotspot motion (100-0 Ma).

\begin{tabular}{l} 
Assumes stable and long-lived. \\
\hline
\end{tabular}

No assumption.

TPW corrected mantle reference from $410-0 \mathrm{Ma}$.

\begin{tabular}{|l|l|l}
\hline Yes & Yes & TPW corrected mantle reference from 410-0 Ma. \\
\hline Yes & Yes & TPW corrected mantle reference from 500-410 Ma. \\
\hline
\end{tabular}

Assumes stable and long-lived.

\begin{tabular}{l|l|l|l} 
Yes & Yes & TPW corrected mantle reference from 500-410 Ma. & Assumes stable and long-lived.
\end{tabular}

TPW corrected mantle reference from 500-410 Ma.

Assumes stable and long-lived.

Hierarchy Structure

Branching.

Flat.

Branching.

\begin{tabular}{l|l|l} 
No & Yes & Optimisation method after Tetley et al. (2019).
\end{tabular}

No assumption.

No assumption.

No assumption.

Branching.

Flat.

Nodal.

Flat.

Yes

No




\section{Table 2}

\begin{tabular}{|c|c|c|c|c|c|c|c|c|c|}
\hline Key & Rockunit & OldAge & YoungAge & Glat & Glon & Plat & Plon & A95 & Reference \\
\hline \multicolumn{10}{|c|}{ Laurentia } \\
\hline L1 & $\begin{array}{l}\text { Gunbarrel Intrusions } \\
\text { combined }\end{array}$ & 780 & 776 & 45 & -110 & 14.6 & 127 & 3.2 & Harlan et al. (2008). \\
\hline L2 & Uinta Formation & 800 & 750 & 41 & -110 & 0.8 & 161.3 & 4.7 & Weil et al. (2006). \\
\hline L3 & $\begin{array}{l}\text { Galeros - Carbon } \\
\text { Canyon }\end{array}$ & 764 & 750 & 35.15 & -111.8 & -0.5 & 166 & 9.7 & $\begin{array}{l}\text { Weil et al. (2004); Eyster et al. } \\
(2019) .\end{array}$ \\
\hline L4 & Kwagunt Formation & 759 & 743 & 36.15 & -112 & 14.2 & 163.8 & 3.5 & Eyster et al. (2019). \\
\hline L5 & $\begin{array}{l}\text { Kwagunt Formation } \\
2\end{array}$ & 748 & 736 & 36.15 & -112 & 18.2 & 166 & 7 & Weil et al. (2004). \\
\hline L6 & Franklin Dykes & 727 & 712 & 75 & -82 & 8.4 & 163.8 & 2.8 & Denyszyn et al. (2009). \\
\hline L7 & Long Range Dykes & 617 & 613 & 53.5 & -57.5 & -19 & 175.3 & 17.4 & $\begin{array}{l}\text { Murthy et al. }(1992) ; \text { Hodych et al. } \\
(2004) \text {; Age: Kamo and Gower } \\
\underline{(1994)} .\end{array}$ \\
\hline L8 & $\begin{array}{l}\text { Skinner Cove } \\
\text { Formation }\end{array}$ & 554 & 548 & 50 & -60 & 15 & 157 & 9 & McCausland and Hodych (1998). \\
\hline $\mathrm{L}^{* * *}$ & Andres Red Beds & 423 & 393 & 41 & -74 & 13 & 105 & 9 & Miller and Kent (1988). \\
\hline $\mathrm{L} 10 * *$ & Wabash Reef & 423 & 415 & 40.85 & -85.7 & 17 & 125 & 5.3 & $\begin{array}{l}\text { McCabe et al. (1985); Torsvik et al. } \\
(1996) .\end{array}$ \\
\hline $\mathrm{L} 11 * *$ & Rose Hill formation & 433 & 427 & 39 & -79 & 19.1 & 128.3 & 5.8 & French and Van der Voo (1979). \\
\hline $\mathrm{L} 12 * *$ & $\begin{array}{l}\text { Ringgold Gap } \\
\text { Sediments }\end{array}$ & 456 & 433 & 34.51 & -85.06 & 24 & 146.6 & 7.7 & Morrison and Ellwood (1986). \\
\hline $\mathrm{L} 13 * *$ & $\begin{array}{l}\text { Tablehead Group } \\
\text { Limestone mean }\end{array}$ & 470 & 456 & 48.33 & -58.43 & 13.4 & 149.3 & 3.9 & $\begin{array}{l}\text { Hodych (1989); Hall and Evans } \\
\text { (1988); Deutsch and Prasad (1987); } \\
\text { Torsvik et al. (1996); Torsvik et al. } \\
(2012) \text {. }\end{array}$ \\
\hline $\mathrm{L} 14 * *$ & $\begin{array}{l}\text { St George Group } \\
\text { Limestone }\end{array}$ & 485 & 456 & 48.3 & -59 & 17.5 & 152.4 & 4.3 & Deutsch and Prasad (1987). \\
\hline $\mathrm{L} 15^{* *}$ & Oneota Dolomite & 485 & 470 & 43.41 & -91.23 & 10.3 & 166.5 & 11.9 & Jackson and Van der Voo (1985) \\
\hline
\end{tabular}




\begin{tabular}{|c|c|c|c|c|c|c|c|c|c|}
\hline $\mathrm{L} 16^{* *}$ & $\begin{array}{l}\text { Moore Hollow } \\
\text { sediments }\end{array}$ & 500 & 490 & 31 & -99 & -0.6 & 163 & 8.5 & Far and Gose (1991). \\
\hline $\mathrm{L} 17 * *$ & Morgan Creek & 497 & 470 & 30.25 & -98.5 & 10.6 & 158 & 9.7 & Loucks an Elmore (1986). \\
\hline $\mathrm{L} 18^{* *}$ & Point Peak & 497 & 485 & 30.5 & -99 & 5.2 & 165.8 & 6 & Van der Voo et al. (1976). \\
\hline L19** & $\begin{array}{l}\text { Taum Sauk } \\
\text { Limestone }\end{array}$ & 497 & 485 & 37.55 & -90.31 & -3.4 & 175.1 & 7.1 & Dunn and Elmore (1985). \\
\hline $\mathrm{L} 20^{* *}$ & Roywe dolomite & 497 & 485 & 34.25 & -97.11 & 12.6 & 157.3 & 4.3 & Nick and Elmore (1990). \\
\hline $\mathrm{L} 21 * *$ & Florida Mountains & 497 & 485 & 32.05 & $\begin{array}{l}- \\
107.37\end{array}$ & -5.4 & 168.7 & 10 & Geissman et al. (1991). \\
\hline $\mathrm{L} 22 * *$ & Tapeats Sandstone & 520 & 497 & 36.11 & - & 2.3 & 162.6 & 3.3 & Elston and Bressler (1977). \\
\hline $\mathrm{L} 23 * *$ & $\begin{array}{l}\text { Mount Rigaud and } \\
\text { Chatham-Grenville }\end{array}$ & 534 & 530 & 45.28 & 24.2 & -11.9 & 184.5 & 6.2 & McClausland et al. (2007). \\
\hline Baltica & & & & & & & & & \\
\hline B1 & $\begin{array}{l}\text { Southern Sweden } \\
\text { Dykes }\end{array}$ & 946 & 935 & 59 & 16 & -0.9 & 240.7 & 6.7 & $\begin{array}{l}\text { Elming et al. (2014); Pisarevsky } \\
\text { and Bylund (1998). }\end{array}$ \\
\hline B2 & $\begin{array}{l}\text { Branton-Algo } \\
\text { Anortthosite }\end{array}$ & 927 & 905 & 58.5 & 6.5 & 5 & 249 & 3.9 & $\begin{array}{l}\text { Stearn and Piper, (1984); Age: } \\
\text { Scherstén et al. } \underline{(2000)} \text {. }\end{array}$ \\
\hline B3 & $\begin{array}{l}\text { Rogaland Igneous } \\
\text { Complex }\end{array}$ & 883 & 855 & 58.5 & 6 & -46 & 238 & 18.1 & Walderhaug et al. (2007). \\
\hline B4 & Hunnedalen Dykes & 875 & 821 & 59 & 6.75 & -41 & 222 & 10 & Walderhaug et al. (1999). \\
\hline B5 & Egersund Dykes & 619 & 613 & 58.5 & 6 & -31.4 & 224.1 & 15.6 & Walderhaug et al. (2007). \\
\hline B6 & $\begin{array}{l}\text { Kurgashlya } \\
\text { Formation }\end{array}$ & 570 & 560 & 53.3 & 57.5 & -51 & 135 & 4.9 & Lubnina et al. (2014). \\
\hline B7 & Bakeevo Formation & 570 & 560 & 54.5 & 58.2 & -42 & 119 & 5.3 & Lubnina et al. (2014). \\
\hline B8 & $\begin{array}{l}\text { Winter coast } \\
\text { sediments }\end{array}$ & 558 & 552 & 65.5 & 40 & -25.3 & 132.5 & 2.8 & $\begin{array}{l}\text { Popov et al. (2002); Age: Martin et } \\
\text { al. }(2000) .\end{array}$ \\
\hline B9 & $\begin{array}{l}\text { Zolotitsa sediments } \\
\text { I, Russia }\end{array}$ & 560 & 550 & 65.5 & 40 & -31.7 & 112.9 & 2.4 & Popov et al. (2005). \\
\hline
\end{tabular}




\begin{tabular}{|c|c|c|c|c|c|c|c|c|c|}
\hline B10 & $\begin{array}{l}\text { Verkhotina } \\
\text { sediments }\end{array}$ & 560 & 550 & 65.5 & 40 & -32.2 & 107.1 & 2 & Popov et al. (2005). \\
\hline B11 & $\begin{array}{l}\text { Zolotitsa sediments } \\
\text { II }\end{array}$ & 560 & 550 & 65.5 & 40 & -28.3 & 109.9 & 3.8 & Iglesia Llanos et al. $\underline{(2005)}$. \\
\hline B12 & Zigan Formation & 552 & 544 & 53.7 & 56.7 & -16 & 138 & 3.7 & Levashova et al. (2013). \\
\hline B13 & $\begin{array}{l}\text { Swedish Limestone } \\
(1 \mathrm{~N})\end{array}$ & 467 & 458 & 58.3 & 13.9 & 3 & 35 & 13.4 & Torsvik \& Trench (1991). \\
\hline B14 & Swedish Limestone & 480 & 470 & 58 & 13 & 30 & 55 & 9 & Torsvik \& Trench (1991). \\
\hline B15 & $\begin{array}{l}\text { Swedish Limestone } \\
(1 \mathrm{R})\end{array}$ & 480 & 470 & 59 & 15 & 18 & 46 & 5.1 & Torsvik \& Trench (1991). \\
\hline B16 & Narva Limestones & 485 & 470 & 59 & 31 & 18 & 55 & 4 & Khramov and Iosifidi (2009). \\
\hline B17 & $\begin{array}{l}\text { St Petersburg } \\
\text { Limestone }\end{array}$ & 480 & 470 & 58 & 30 & 33 & 58 & 3.6 & Smethurst et al., (1998). \\
\hline B18+ & $\begin{array}{l}\text { Gotland Follingbo } \\
\text { Limestone }\end{array}$ & 430 & 420 & 57.5 & 18.5 & 21 & 164 & 6 & Claesson (1979). \\
\hline B19+ & $\begin{array}{l}\text { Dniestr Silurian } \\
\text { Lmst. }\end{array}$ & 428 & 416 & 48.6 & 27 & 14.3 & 169.3 & 7.4 & Jelenska et al. (2005). \\
\hline $\mathrm{B} 20+$ & $\begin{array}{l}\text { Gotland Medby } \\
\text { Limest. }\end{array}$ & 427 & 417 & 57.5 & 18.5 & 23 & 171 & 8 & Claesson (1979). \\
\hline B21+ & $\begin{array}{l}\text { Ringerike Sandst. } \\
\text { Norway }\end{array}$ & 426 & 410 & 60 & 10.2 & 19 & 164 & 6.7 & Douglass. (1988). \\
\hline $\mathrm{B} 22+$ & Tiverskaya Series & 419 & 411 & 48.6 & 27 & 0 & 149 & 13.3 & Jelenska et al. (2015). \\
\hline $\mathrm{B} 23+$ & $\begin{array}{l}\text { Ivaniev and Dniestr } \\
\text { Sediments }\end{array}$ & 419 & 393 & 48.7 & 26 & -1 & 175 & 9.6 & Lubnina et al (2007). \\
\hline B24+ & $\begin{array}{l}\text { Devonian Seds. } \\
\text { Podolia }\end{array}$ & 416 & 406 & 48.7 & 26 & -3.7 & 145.5 & 6.7 & Smethurst and Khramov (1992). \\
\hline B25+ & $\begin{array}{l}\text { Dniestrovskaya } \\
\text { Series }\end{array}$ & 416 & 407 & 48.6 & 27 & 2.3 & 158.4 & 7.4 & Jelenska et al. (2005). \\
\hline B26+ & $\begin{array}{l}\text { Zilair Sediments, } \\
\text { Russia }\end{array}$ & 411 & 375 & 54 & 59 & -2 & 161 & 3.1 & Danukalov et al. (1983). \\
\hline B27+ & $\begin{array}{l}\text { Eifelian sedimentary } \\
\text { rocks, Russia }\end{array}$ & 398 & 392 & 50 & 5 & 19 & 173 & 2.9 & Minibaev and Sulutdinov (1991). \\
\hline
\end{tabular}




\begin{tabular}{|c|c|c|c|c|c|c|c|c|c|}
\hline B28+ & $\begin{array}{l}\text { Bashkirea } \\
\text { Sediments, Russia }\end{array}$ & 398 & 385 & 54 & 59 & -7 & 162 & 4.8 & Danukalov et al. (1983). \\
\hline B29+ & Kola Dykes, Russia & 390 & 370 & 68 & 33 & 11 & 147.6 & 11.1 & $\begin{array}{l}\text { Veselovsky and Arzamastsev } \\
\underline{(2011)} .\end{array}$ \\
\hline \multicolumn{10}{|c|}{ Siberia } \\
\hline S1 & Ust-Kirba Formation & 960 & 930 & 60 & 137.2 & 8.1 & 2.6 & 10.4 & Popov et al. (2002). \\
\hline $\mathrm{S} 2$ & Kitoi Dykes & 762 & 754 & 52 & 103 & 0.4 & 21.8 & 6.1 & Pisarevsky et al. (2013). \\
\hline S3 & Kesyussa Formation & 542 & 535 & 71 & 122.5 & -37.6 & 165 & 5.2 & Pisarevsky et al. (1997). \\
\hline S4- & $\begin{array}{l}\text { Moyero River } \\
\text { sediments }\end{array}$ & 459 & 439 & 68 & 104 & -14 & 124 & 8 & Gallet and pavlov (1996). \\
\hline S5- & $\begin{array}{l}\text { Angara River } \\
\text { sediments* }\end{array}$ & 460 & 450 & 58.5 & 99.8 & -29.5 & 140.2 & 6.4 & Pavlov et al. (2012). \\
\hline S6- & Kulumbe section & 466 & 456 & 68 & 88.8 & -24.1 & 152.4 & 3.3 & Pavlov et al. (2008). \\
\hline S7- & Stolobovaya section & 466 & 456 & 62.1 & 92.5 & -22 & 158 & 4 & Pavlov et al. (2008). \\
\hline S8- & $\begin{array}{l}\text { Moyero River } \\
\text { sediments }\end{array}$ & 468 & 458 & 68 & 104 & -23 & 158 & 4 & Gallet and Pavlov (1996). \\
\hline S9- & $\begin{array}{l}\text { Angara River } \\
\text { sediments }\end{array}$ & 473 & 463 & 58.5 & 99.8 & -35.2 & 153.2 & 3.6 & Pavlov et al. (2012). \\
\hline S10- & $\begin{array}{l}\text { Moyero River } \\
\text { sediments }\end{array}$ & 474 & 464 & 68 & 104 & -30 & 157 & 4 & Gallet and Pavlov (1996). \\
\hline S11- & Guragir Formation & 475 & 465 & 68 & 88.8 & -30.9 & 152.7 & 3.2 & Pavlov and Gallet(1998). \\
\hline S12- & $\begin{array}{l}\text { Angara River } \\
\text { sediments }\end{array}$ & 480 & 470 & 58.5 & 99.8 & -36.4 & 158.2 & 6.5 & Pavlov et al. (2012). \\
\hline S13- & $\begin{array}{l}\text { Moyero River } \\
\text { sediments }\end{array}$ & 483 & 473 & 67.5 & 104 & -33.9 & 151.7 & 2.2 & Gallet and Pavlov (1996). \\
\hline
\end{tabular}




\begin{tabular}{|c|c|c|c|c|c|c|c|c|c|}
\hline S14- & $\begin{array}{l}\text { Uigur and } \\
\text { Nizhneiltyk } \\
\text { Formations }\end{array}$ & 488 & 478 & 68 & 88.8 & -35.2 & 127.2 & 4.9 & Pavlov and Gallet (1998). \\
\hline S15- & $\begin{array}{l}\text { Moyero River } \\
\text { sediments }\end{array}$ & 488 & 478 & 68 & 104 & -40 & 138 & 9 & Gallet and Pavlov (1996). \\
\hline S16- & $\begin{array}{l}\text { Kulumbinskaya } \\
\text { Formation }\end{array}$ & 505 & 495 & 68 & 88.8 & -36.1 & 130.7 & 6 & Pavlov and Gallet (1998). \\
\hline S17- & $\begin{array}{l}\text { Moyero River } \\
\text { sediments }\end{array}$ & 505 & 495 & 68 & 104 & -37 & 138 & 9 & Gallet and Pavlov (1996). \\
\hline $\mathrm{S} 18$ & $\begin{array}{l}\text { Yunkyulyabit- } \\
\text { Yuryakh Formation }\end{array}$ & 512 & 502 & 70.9 & 122.6 & -36.4 & 139.6 & 4.6 & Pisarevsky et al. (1997). \\
\hline S19- & $\begin{array}{l}\text { Kulumbe River } \\
\text { section }\end{array}$ & 512 & 502 & 68 & 88.4 & -41.9 & 135.8 & 2.3 & Pavlov and Gallet (1998). \\
\hline S20- & $\begin{array}{l}\text { Khorbusuonka } \\
\text { Amgan and Mayan } \\
\text { seds. }\end{array}$ & 512 & 502 & 71.5 & 124 & -43.7 & 140.5 & 2.6 & Gallet et al. (2003). \\
\hline S21- & $\begin{array}{l}\text { Nyuya and Lena } \\
\text { River sediments }\end{array}$ & 437 & 427 & 60.6 & 116.3 & -17.6 & 102 & 3.2 & Powerman et al. (2013). \\
\hline S22- & $\begin{array}{l}\text { Nyuya and Lena } \\
\text { River sediments }\end{array}$ & 438 & 428 & 60.7 & 116.3 & -18.6 & 101.9 & 4.6 & Shatsillo et al. (2007). \\
\hline S23- & $\begin{array}{l}\text { Lena River } \\
\text { sediments }\end{array}$ & 454 & 444 & 60.5 & 116.4 & -21 & 109 & 17.3 & Torsvik et al. (1995). \\
\hline S24- & $\begin{array}{l}\text { Nyuya River } \\
\text { sediments }\end{array}$ & 456 & 446 & 60.6 & 116.3 & -31.3 & 129.5 & 3.6 & Powerman et al. (2013). \\
\hline S25- & Kudrino section & 466 & 456 & 57.7 & 107.99 & -21.1 & 143.4 & 5 & Pavlov et al. (2008). \\
\hline S26- & $\begin{array}{l}\text { Krivaya Luka } \\
\text { Formation }\end{array}$ & 469 & 459 & 59.7 & 118.1 & -25.6 & 117.9 & 5.1 & Iosifide et al. (1999). \\
\hline S27- & $\begin{array}{l}\text { Krivaya Luka } \\
\text { Formation }\end{array}$ & 469 & 459 & 59.7 & 118.1 & -28.2 & 127.1 & 2.5 & Iosifide et al. (1999). \\
\hline S28- & Krivolutsky Suite & 470 & 460 & 57.6 & 107.8 & -32.6 & 137 & 8.3 & Rodionov et al. (2003). \\
\hline S29- & $\begin{array}{l}\text { Lena River } \\
\text { sediments }\end{array}$ & 473 & 463 & 59.8 & 118.1 & -32 & 139 & 3.1 & Torsvik et al. (1995). \\
\hline
\end{tabular}




\begin{tabular}{|c|c|c|c|c|c|c|c|c|c|}
\hline S30- & Lena River redbeds & 475 & 465 & 60 & 114 & -25 & 137 & 9 & Rodionev et al. (1966). \\
\hline S31- & Surinsk Formation & 485 & 475 & 58.3 & 109.61 & -42.2 & 128.1 & 5.8 & Surkis et al. (1999). \\
\hline S32- & $\begin{array}{l}\text { Verkholensk } \\
\text { Formation }\end{array}$ & 506 & 496 & 58.5 & 109.8 & $\begin{array}{l}- \\
37.69\end{array}$ & 124 & 4.5 & Rodionev et al. (1998). \\
\hline S33- & $\begin{array}{l}\text { Maya River } \\
\text { sediments }\end{array}$ & 515 & 505 & 60 & 132 & -45.8 & 115 & 5 & Pavlovl et al. (2008). \\
\hline \multicolumn{10}{|c|}{ West Australia } \\
\hline WA1 & Browne Formation & 830 & 730 & -26 & 126 & 44.5 & 141.7 & 6.8 & Pisarevsky et al. (2007). \\
\hline WA2 & Hussar Formation & 800 & 730 & -26 & 126 & 62.2 & 85.8 & 10.3 & Pisarevsky et al. (2007). \\
\hline WA3 & Mundine Dykes & 758 & 752 & -23 & 115.8 & 45.3 & 135.4 & 4.1 & Wingate and Giddings (2000). \\
\hline \multicolumn{10}{|c|}{ North Australia } \\
\hline NA1 & $\begin{array}{l}\text { Johnny's Creek } \\
\text { Member }\end{array}$ & 780 & 660 & -24 & 133 & 15.8 & 83 & 13.5 & Swanson-Hysell et al. (2012). \\
\hline \multicolumn{10}{|c|}{ South Australia } \\
\hline SA1 & Angepena Formation & 660 & 640 & -32 & 138 & 47.1 & 176.6 & 5.3 & Williams and Schmidt (2015). \\
\hline $\mathrm{SA} 2$ & Yaltipena Formation & 650 & 635 & -31.5 & 139 & 44.2 & 172.7 & 8.2 & Sohl et al. (1999). \\
\hline SA3 & $\begin{array}{l}\text { Elatina Formation, } \\
\text { MEAN }\end{array}$ & 645 & 635 & -32 & 137.5 & 49.9 & 164.4 & 13.5 & $\begin{array}{l}\text { Embleton and Williams } \underline{(1986)} \text {; } \\
\text { Schmidt et al. (1991); Schmidt and } \\
\text { Williams (1995); Sohl et al. (1999). }\end{array}$ \\
\hline SA4 & $\begin{array}{l}\text { Nuccaleena } \\
\text { Formation }\end{array}$ & 635 & 610 & -31 & 139 & 32.3 & 170.8 & 2.9 & Schmidt et al. $\underline{(2009)}$. \\
\hline SA5 & Brachina Formation & 620 & 590 & -32.2 & 138 & 46 & 135.4 & 3.3 & Schmidt and Williams (2010). \\
\hline SA6 & Bunyeroo Formation & 590 & 570 & -31.6 & 138.4 & 18.1 & 196.3 & 8.8 & Schmidt and Williams (1996). \\
\hline
\end{tabular}




\begin{tabular}{|c|c|c|c|c|c|c|c|c|c|}
\hline SA7 & Wonoka Formation & 575 & 555 & -31.3 & 138.6 & 5.2 & 210.5 & 4.9 & Schmidt and Williams $\underline{(2010)}$. \\
\hline \multicolumn{10}{|c|}{ North China } \\
\hline $\mathrm{NC} 1$ & $\begin{array}{l}\text { Huaibei Sills } 890 \\
\text { Ma }\end{array}$ & 913 & 876 & 34 & 117 & -52.3 & 149.3 & 3.5 & Fu et al. $\underline{(2015)}$. \\
\hline $\mathrm{NC} 2$ & $\begin{array}{l}\text { Wudaotang and } \\
\text { Xinji Fm }\end{array}$ & 541 & 521 & 35.6 & 110.5 & 18.5 & 341.9 & 6.5 & Huang et al. (1999). \\
\hline $\mathrm{NC} 3$ & $\begin{array}{l}\text { Hebei and Shandong } \\
\text { Sediments }\end{array}$ & 541 & 501 & 36 & 118 & 21.2 & 335.2 & 12.4 & Zhao et al. (1992). \\
\hline $\mathrm{NC} 4$ & $\begin{array}{l}\text { NE Sino-Korean } \\
\text { Massif }\end{array}$ & 541 & 485 & 35.6 & 110.5 & 26.8 & 334.5 & 8.9 & $\begin{array}{l}\text { Gao et al. } \underline{(1983)} \text { (recalculated by } \\
\text { Zhao et al. (1992)). }\end{array}$ \\
\hline NC5- & $\begin{array}{l}\text { Zhangxia and } \\
\text { Xuzhuang Fms }\end{array}$ & 510 & 496 & 35.6 & 110.5 & 37 & 326.7 & 5.5 & Huang et al. (1999). \\
\hline NC6- & $\begin{array}{l}\text { Zhaogezhuang area } \\
\text { carbonates }\end{array}$ & 490 & 467 & 39.7 & 118.5 & 32.9 & 294.6 & 4.7 & Yang et al. (2002). \\
\hline NC7- & $\begin{array}{l}\text { Changshan and } \\
\text { Gushan Fms }\end{array}$ & 496 & 485 & 35.6 & 110.5 & 31.7 & 329.6 & 5.4 & Huang et al. (1999). \\
\hline NC8- & $\begin{array}{l}\text { Hebei and Shandong } \\
\text { Sediments }\end{array}$ & 499 & 461 & 36 & 118 & 28.8 & 310.9 & 12.3 & Zhao et al. (1992). \\
\hline NC9- & $\begin{array}{l}\text { Liangjiashan and } \\
\text { Lower Majiagou Fm }\end{array}$ & 485 & 470 & 35.6 & 110.5 & 37.4 & 324.3 & 8.5 & Huang et al. (1999). \\
\hline NC10- & Jinghe & 470 & 456 & 35.6 & 110.5 & 31.5 & 327.7 & 7 & Huang et al. (1999). \\
\hline $\mathrm{NC} 11$ & $\begin{array}{l}\text { Upper Majiagou } \\
\text { Formation }\end{array}$ & 470 & 456 & 35.6 & 110.5 & 27.9 & 310.4 & 9.2 & Yang et al. (1996). \\
\hline NC12- & $\begin{array}{l}\text { Tianjinshan and } \\
\text { Miboshan } \\
\text { Formations }\end{array}$ & 480 & 464 & 37.2 & 105.5 & 31.8 & 326.5 & 9.5 & Huang et al. (1999). \\
\hline South Cl & & & & & & & & & \\
\hline $\mathrm{SC} 1$ & Yanbian Dykes A & 830 & 818 & 26.5 & 101.5 & 45.1 & 130.4 & 19 & Niu et al. (2016). \\
\hline
\end{tabular}




\begin{tabular}{|c|c|c|c|c|c|c|c|c|c|}
\hline $\mathrm{SC} 2$ & Xiaofeng Dykes & 812 & 792 & 31 & 111 & 13.5 & 91 & 10.9 & Li et al. (2004). \\
\hline $\mathrm{SC} 3 *$ & Yanbian Dykes B & 814 & 798 & 26.5 & 101.5 & 14.1 & 32.5 & 20.4 & Niu et al. (2016). \\
\hline $\mathrm{SC} 4$ & Liantuo Formation & 735 & 705 & 30.8 & 111 & 9.9 & 160.3 & 4.6 & $\begin{array}{l}\text { Jing et al. }(2015) \text { and Evans et al. } \\
(2000) \text {, combined. }\end{array}$ \\
\hline SC5 & Nantuo Formation & 641 & 631 & 28.5 & 110 & 7.5 & 161.6 & 5.9 & $\begin{array}{l}\text { Zhang et al. (2013); Zhang and } \\
\text { Piper (1997). }\end{array}$ \\
\hline SC6 & $\begin{array}{l}\text { Doushantuo } \\
\text { Formation }\end{array}$ & 614 & 590 & 30.8 & 111 & 25.9 & 185.5 & 6.7 & Zhang et al. (2015). \\
\hline SC7- & $\begin{array}{l}\text { Douposi Formation } \\
\text { (Wangcang) }\end{array}$ & 510 & 496 & 32.1 & 106.2 & -39.5 & 185.1 & 8.3 & Lixin et al. (1998). \\
\hline SC8- & $\begin{array}{l}\text { Douposi Formation } \\
\text { (Guangyuan) }\end{array}$ & 510 & 496 & 32.4 & 106.3 & -51.3 & 166 & 8.3 & Yang et al. (2004). \\
\hline SC9- & Shiqian Redbeds & 440 & 425 & 27.5 & 108 & 4.9 & 194.7 & 5.6 & Opdyke et al. (1987). \\
\hline SC10- & Shiqian Redbeds & 440 & 425 & 27.5 & 108 & 14.9 & 196.1 & 5.1 & Huang et al. (2000). \\
\hline SC11- & Pagoda Formation & 458 & 445 & 32.4 & 106.3 & -45.8 & 191.3 & 3.6 & Han et al. (2015). \\
\hline \multicolumn{10}{|l|}{ Congo } \\
\hline $\mathrm{C} 1$ & Luakela Volcanics A & 770 & 757 & -11.5 & 24.25 & -40.2 & 122 & 14.1 & Wingate et al. (2010). \\
\hline $\mathrm{C} 2$ & Mbozi Complex & 773 & 713 & -9.2 & 32.8 & -46 & 145 & 6.7 & Meert et al. (1995). \\
\hline \multicolumn{10}{|c|}{ Sao Francisco } \\
\hline SF1 & Bahia Dykes $(\mathrm{N}+\mathrm{R})$ & 928 & 912 & -14 & -39 & 7.3 & 106.4 & 6.2 & Evans et al. (2016). \\
\hline \multicolumn{10}{|l|}{ Tarim } \\
\hline $\mathrm{T} 1 *$ & Sugetbrak Formation & 635 & 550 & 40.9 & 79.4 & 19.1 & 149.7 & 9.3 & Zhan et al. (2007). \\
\hline
\end{tabular}




\begin{tabular}{|c|c|c|c|c|c|c|c|c|c|}
\hline $\mathrm{T} 2 *$ & Zhamoketi Andesite & 621 & 609 & 41.5 & 87.8 & -4.9 & 146.7 & 3.9 & Zhao et al. (2014). \\
\hline $\mathrm{T} 3$ & $\begin{array}{l}\text { Lower Sugetbrak } \\
\text { Formation }\end{array}$ & 640 & 615 & 41 & 79.5 & -21.1 & 87.4 & 7 & Wen et al. (2017). \\
\hline $\mathrm{T} 4 *$ & $\begin{array}{l}\text { Tereeken Cap } \\
\text { Carbonate }\end{array}$ & 640 & 630 & 41.5 & 87.8 & 27.6 & 140.4 & 9.9 & Zhao et al. (2014). \\
\hline T5 & $\begin{array}{l}\text { Qiaoenbrak } \\
\text { Formation, Aksu }\end{array}$ & 760 & 720 & 40.8 & 79.5 & -6.3 & 17.5 & 9.1 & Wen et al. (2013). \\
\hline $\mathrm{T} 6^{*}$ & Aksu Dykes & 819 & 795 & 41.15 & 80.1 & 19 & 128 & 4.5 & Chen et al. (2004). \\
\hline $\mathrm{T} 7$ & Baiyisi Volcanics & 770 & 717 & 41.6 & 86.54 & -17.7 & 14.2 & 6 & Huang et al. (2005). \\
\hline T8- & $\begin{array}{l}\text { Ordovician } \\
\text { Limestones }\end{array}$ & 485 & 470 & 41.3 & 83.4 & -20.4 & 180.6 & 8.5 & Fang et al. (1996). \\
\hline T9- & $\begin{array}{l}\text { Aksu-Kalpin-Bachu } \\
\text { area sediments }\end{array}$ & 455 & 445 & 40.6 & 78.9 & -40.7 & 183.3 & 4.8 & Sun and Huang (2009). \\
\hline $\mathrm{T} 10$ & Red Sandstone & 433 & 427 & 40.6 & 79.4 & 12.8 & 159.8 & 7.3 & $\begin{array}{l}\text { Zhao et al. } \underline{(2014)}(2014) \text { average of } \\
\text { three poles from Fang et al. } \underline{(1996)} \text {; } \\
\text { Li et al. } \underline{(1990)} \text {; Fang et al. } \underline{(1998)} \text {. }\end{array}$ \\
\hline \multicolumn{10}{|l|}{ India } \\
\hline I1 & $\begin{array}{l}\text { Malani Igneous } \\
\text { Suite Grand Mean }\end{array}$ & 770 & 734 & 26 & 72 & 69.4 & 75.7 & 6.5 & Meert et al. (2013). \\
\hline $\mathrm{I} 2$ & $\begin{array}{l}\text { Bhander and Rewa } \\
\text { formations }\end{array}$ & 650 & 530 & 26 & 78 & 47.3 & 212.7 & 5.8 & McElhinny et al. (1978). \\
\hline $\mathrm{I} 3 *$ & Jodphur Group & 570 & 520 & 27 & 73 & 1 & 164 & 6.7 & Davis et al. (2014). \\
\hline \multicolumn{10}{|c|}{ Seychelles } \\
\hline SE1 & Mahe Dykes & 753 & 747 & -4.7 & 55.5 & 54.8 & 57.6 & 12.1 & Torsvik et al. (2001). \\
\hline & & & & & & & & & \\
\hline
\end{tabular}




\begin{tabular}{|c|c|c|c|c|c|c|c|c|c|}
\hline RP1 & $\begin{array}{l}\text { Sierra de las Animas } \\
\text { Complex }\end{array}$ & 582 & 574 & -34 & -55.3 & 12.2 & 78.9 & 14.9 & Rapalini et al. (2015). \\
\hline RP2 & $\begin{array}{l}\text { Sierra de los } \\
\text { Barrientos Redbeds }\end{array}$ & 600 & 500 & -37.8 & -59 & 15.1 & 72.6 & 12.4 & Rapalini et al. (2006). \\
\hline \multicolumn{10}{|c|}{ West African Craton } \\
\hline WAC1 & Djebel Boho Volc. & 547 & 526 & 30.4 & -6.7 & -27.3 & 207.1 & 14.9 & Robert et al. (2017). \\
\hline WAC2 & $\begin{array}{l}\text { Fajjoud and } \\
\text { Tadoughast Volc. }\end{array}$ & 572 & 551 & 30.2 & -7.8 & -21.9 & 211 & 15.6 & Robert et al. (2017). \\
\hline WAC3* & $\begin{array}{l}\text { Adrar-n-takoucht } \\
\text { Volc }\end{array}$ & 577 & 564 & 30.4 & -7.8 & 57.6 & 115.6 & 15.7 & Robert et al. (2017). \\
\hline \multicolumn{10}{|c|}{ East Avalonia } \\
\hline EAV1\#,1 & Treffgarne volcanics & 482 & 472 & 52 & -5 & -56 & 126 & 5.5 & Trench et al. (1992). \\
\hline EAV2\# & Stapeley volcanics & 471 & 463 & 52.6 & -3 & -26.6 & 216.1 & 4.9 & McCabe and Channell (1990). \\
\hline EAV3\# & $\begin{array}{l}\text { Builth igneous and } \\
\text { sediments }\end{array}$ & 468 & 460 & 52.1 & -3.3 & -11 & 198 & 10 & McCabe et al. (1992). \\
\hline EAV4\# & Tramore volcanics & 461 & 449 & 52.1 & -7.4 & -11 & 198 & 8.5 & $\begin{array}{l}\text { Deutsch } \underline{(1980)} \text {; Trench and } \\
\text { Torsvik } \underline{(1991)} \text {. }\end{array}$ \\
\hline EAV5\# & $\begin{array}{l}\text { Borrowdale } \\
\text { volcanics }\end{array}$ & 448 & 438 & 54.4 & -3.2 & -8.1 & 186.2 & 6.9 & $\begin{array}{l}\text { Millward and Evans (2003); } \\
\text { Channell and McCabe (1992). }\end{array}$ \\
\hline EAV6\#,2 & $\begin{array}{l}\text { Midlands Minor } \\
\text { Intrusives }\end{array}$ & 442 & 432 & 52.5 & -1.5 & -52.5 & 181.5 & 10.4 & Vizan et al. (2003). \\
\hline EAV7\#,2 & Browgill redbeds & 439 & 433 & 54.3 & -2.5 & -13.6 & 133.9 & 12.4 & Channell et al. (1993). \\
\hline EAV8\#,2 & Tortworth volcanics & 437 & 431 & 51.7 & -2.5 & 7 & 124 & 4.7 & Torsvik et al. (1994). \\
\hline EAV9\#,2 & Mendips volcanics & 435 & 429 & 51.2 & -2.5 & -13 & 91 & 8.8 & Torsvik et al. (1993). \\
\hline
\end{tabular}




\begin{tabular}{|c|c|c|c|c|c|c|c|c|c|}
\hline \multicolumn{10}{|l|}{ Ganderia } \\
\hline GAN1\# & Bourinot Group & 510 & 496 & 46.1 & -60.4 & -21 & 160 & 8.1 & Johnson and Van der Vood (1985). \\
\hline \multicolumn{10}{|c|}{ West Avalonia } \\
\hline WAV1\# & Nahant intrusives & 490 & 488 & 42.4 & -70.9 & -34 & 140 & 3.9 & Thompson et al. (2010). \\
\hline WAV2\# & $\begin{array}{l}\text { Dunn Point } \\
\text { volcanics }\end{array}$ & 463 & 457 & 45.8 & -62.1 & 2 & 130 & 4.1 & $\begin{array}{l}\text { Johnson and Van Der Voo } \underline{(1990)} \text {; } \\
\text { Hamilton and Murphy } \underline{(2004)} \text {. }\end{array}$ \\
\hline WAV3\# & Cape St. Mary sills & 443 & 439 & 46.8 & -54 & 10 & 140 & 9 & Hodych and Buchan (1998). \\
\hline \multicolumn{10}{|l|}{ Carolinia } \\
\hline CAR $1 \#, 2$ & $\begin{array}{l}\text { Cid Formation } \\
\text { metasediments }\end{array}$ & 450 & 445 & 35 & -80.2 & 29.6 & 122.1 & 5.1 & Vick et al. (1987). \\
\hline CAR2\#,2 & $\begin{array}{l}\text { Uwharrie and Cid } \\
\text { Formation metaseds }\end{array}$ & 450 & 445 & 35.5 & -80 & 20 & 80 & 14.2 & Noel et al. (1988). \\
\hline \multicolumn{10}{|l|}{ Cuyania } \\
\hline CUY1\# & $\begin{array}{l}\text { Pavon Formation } \\
\text { sediments }\end{array}$ & 458 & 452 & -34.6 & -68.6 & -3.6 & 166.4 & 6.6 & Rapalini and Cingolani (2004). \\
\hline \multicolumn{10}{|c|}{ * pole not fit by model } \\
\hline \multicolumn{10}{|c|}{ \# from compilation of Domeier (2016) } \\
\hline \multicolumn{10}{|c|}{+ from compilation of S. Pisarevsky (Pers. Comm.) } \\
\hline \multicolumn{10}{|c|}{ - from compilation of Domeier (2018) } \\
\hline \multicolumn{10}{|c|}{ ** from compilation of Torsvik et al. (2012) } \\
\hline \multicolumn{10}{|c|}{1 inclination only used } \\
\hline \multicolumn{10}{|c|}{2 no upper age constraint (fits inclination data) } \\
\hline Glat, samp & le site latitude; Glon, sa & le si & & e latit & ; Plon & le lo & Ide; & 5,95 & onfidence ellipse. \\
\hline
\end{tabular}

1814

1815 
Ahmad, M., Munson, T.J., 2013. Geology and mineral resources of the Northern Territory. Northern Territory Geological Survey Special Publication 5.

Alessio, B.L., Blades, M.L., Murray, G., Thorpe, B., Collins, A.S., Kelsey, D.E., Foden, J., Payne, J., AlKhirbash, S., Jourdan, F., 2018. Origin and tectonic evolution of the NE basement of Oman: a window into the Neoproterozoic accretionary growth of India? Geol. Mag. 155, 1150-1174. https://doi.org/10.1017/S0016756817000061

Alexeiev, D.V., Biske, G.S., Kröner, A., Tretyakov, A.A., Kovach, V.P., Rojas-Agramonte, Y., 2020. Ediacaran, Early Ordovician and early Silurian arcs in the South Tianshan orogen of Kyrgyzstan. J. Asian Earth Sci. 190, 104194. https://doi.org/10.1016/j.jseaes.2019.104194

Alexeiev, D.V., Kröner, A., Kovach, V.P., Tretyakov, A.A., Rojas-Agramonte, Y., Degtyarev, K.E., Mikolaichuk, A.V., Wong, J., Kiselev, V.V., 2019. Evolution of Cambrian and Early Ordovician arcs in the Kyrgyz North Tianshan: Insights from U-Pb zircon ages and geochemical data. Gondwana Res. 66, 93-115. https://doi.org/10.1016/j.gr.2018.09.005

Alexeiev, D.V., Ryazantsev, A.V., Kröner, A., Tretyakov, A.A., Xia, X., Liu, D.Y., 2011. Geochemical data and zircon ages for rocks in a high-pressure belt of Chu-Yili Mountains, southern Kazakhstan: Implications for the earliest stages of accretion in Kazakhstan and the Tianshan. J. Asian Earth Sci. 42, 805-820. https://doi.org/10.1016/j.jseaes.2010.09.004

Archibald, D.B., Collins, A.S., Foden, J.D., 2017. Tonian arc magmatism in central Madagascar: the petrogenesis of the Imorona-Itsindro Suite. The Journal of.

Archibald, D.B., Collins, A.S., Foden, J.D., Payne, J.L., Macey, P.H., Holden, P., Razakamanana, T., 2018. Stenian-Tonian arc magmatism in west-central Madagascar: the genesis of the Dabolava Suite. J. Geol. Soc. London 175, 111-129. https://doi.org/10.1144/jgs2017-028

Armistead, S.E., Collins, A.S., Merdith, A.S., Payne, J.L., Cox, G.M., Foden, J.D., Razakamanana, T., De Waele, B., 2019. Evolving marginal terranes during Neoproterozoic supercontinent reorganisation: constraints from the Bemarivo Domain in northern Madagascar. Tectonics. https://doi.org/10.1029/2018TC005384

Armstrong, R.A., Master, S., Robb, L.J., 2005. Geochronology of the Nchanga Granite, and constraints on the maximum age of the Katanga Supergroup, Zambian Copperbelt. J. Afr. Earth. Sci. 42, 3240. https://doi.org/10.1016/j.jafrearsci.2005.08.012

Arthaud, F., Matte, P., 1977. Late Paleozoic strike-slip faulting in southern Europe and northern Africa: Result of a right-lateral shear zone between the Appalachians and the Urals. GSA Bulletin 88, 1305-1320. 2.0.CO;2">https://doi.org/10.1130/0016-7606(1977)88<1305:LPSFIS >2.0.CO;2 
Ashwal, L.D., Solanki, A.M., Pandit, M.K., Corfu, F., Hendriks, B.W.H., Burke, K., Torsvik, T.H., 2013. Geochronology and geochemistry of Neoproterozoic Mt. Abu granitoids, NW India: Regional correlation and implications for Rodinia paleogeography. Precambrian Res. 236, 265-281. https://doi.org/10.1016/j.precamres.2013.07.018

Austermann, J., Ben-Avraham, Z., Bird, P., Heidbach, O., Schubert, G., Stock, J.M., 2011. Quantifying the forces needed for the rapid change of Pacific plate motion at 6Ma. Earth Planet. Sci. Lett. 307, 289-297. https://doi.org/10.1016/j.eps1.2011.04.043

Austermann, J., Kaye, B.T., Mitrovica, J.X., Huybers, P., 2014. A statistical analysis of the correlation between large igneous provinces and lower mantle seismic structure. Geophys. J. Int. 197, 1-9. https://doi.org/10.1093/gji/ggt500

Barker, C.A., Secor, Jr., T., D., Pray, J.R., Wright, J.E., 1998. Age and Deformation of the Longtown Metagranite, South Carolina Piedmont: A Possible Constraint on the Origin of the Carolina Terrane. J. Geol. 106, 713-726. https://doi.org/10.1086/516055

Bebout, G.E., 1995. The impact of subduction-zone metamorphism on mantle-ocean chemical cycling. Chem. Geol. 126, 191-218. https://doi.org/10.1016/0009-2541(95)00118-5

Berry, R.F., Steele, D.A., Meffre, S., 2008. Proterozoic metamorphism in Tasmania: Implications for tectonic reconstructions. Precambrian Res. 166, 387-396. https://doi.org/10.1016/j.precamres.2007.05.004

Bevier, M.L., Barr, S.M., White, C.E., Macdonald, A.S., 1993. U-Pb geochronologic constraints on the volcanic evolution of the Mira (Avalon) terrane, southeastern Cape Breton Island, Nova Scotia. Can. J. Earth Sci. 30, 1-10. https://doi.org/10.1139/e93-001

Black, L.P., 1997. Dating Tasmania’s oldest geological events. Australian Geological Survey Organisation.

Black, R., Latouche, L., Liégeois, J.P., Caby, R., Bertrand, J.M., 1994. Pan-African displaced terranes in the Tuareg shield (central Sahara). Geology 22, 641-644. 2.3.CO;2">https://doi.org/10.1130/0091-7613(1994)022<0641:PADTIT>2.3.CO;2

Blades, M.L., Alessio, B.L., Collins, A.S., Foden, J., Payne, J.L., Glorie, S., Holden, P., Thorpe, B., AlKhirbash, S., 2019a. Unravelling the Neoproterozoic accretionary history of Oman, using an array of isotopic systems in zircon. J. Geol. Soc. London. https://doi.org/10.1144/jgs2018-125

Blades, M.L., Collins, A.S., Foden, J., Payne, J.L., Stüwe, K., Hassan, M., Abu-Alam, T., submitted. Age and Hafnium Isotope Evolution of Sudanese Butana and Chad Illuminates the Stenian to Ediacaran Evolution of the Southeast Sahara Metacraton. Precambrian Res.

Blades, M.L., Collins, A.S., Foden, J., Payne, J.L., Xu, X., Alemu, T., Woldetinsae, G., Clark, C., Taylor, R.J.M., 2015. Age and hafnium isotopic evolution of the Didesa and Kemashi Domains, western 
Ethiopia. Precambrian Res. 270, 267-284. https://doi.org/10.1016/j.precamres.2015.09.018

Blades, M.L., Foden, J., Collins, A.S., Alemu, T., Woldetinsae, G., 2019b. The origin of the ultramafic rocks of the Tulu Dimtu Belt, western Ethiopia--do they represent remnants of the Mozambique Ocean? Geol. Mag. 156, 62-82.

Bleeker, W., 2003. The late Archean record: a puzzle in ca. 35 pieces. Lithos 71, 99-134. https://doi.org/10.1016/j.lithos.2003.07.003

Bodorkos, S., Crowley, J.L., Claoué-Long, J.C., Anderson, J.R., Magee, C.W., 2020. Precise U-Pb baddeleyite dating of the Derim Derim Dolerite, McArthur Basin, Northern Territory: old and new SHRIMP and ID-TIMS constraints. Aust. J. Earth Sci. 1-15. https://doi.org/10.1080/08120099.2020.1749929

Bower, D.J., Gurnis, M., Seton, M., 2013. Lower mantle structure from paleogeographically constrained dynamic Earth models. Geochem. Geophys. Geosyst. 14, 44-63. https://doi.org/10.1029/2012GC004267

Boyden, J.A., Müller, R.D., Gurnis, M., Torsvik, T.H., Clark, J.A., Turner, M., Ivey-Law, H., Watson, R.J., Cannon, J.S., 2011. Next-generation plate tectonic reconstructions, in: Keller, G.R., Baru, C. (Eds.), Geoinformatics: Cyberinfrastructure for the Solid Earth Sciences. Cambridge University Press, Cambridge, pp. 95-113.

Brenner, A.R., Fu, R.R., Evans, D.A.D., Smirnov, A.V., Trubko, R., Rose, I.R., 2020. Paleomagnetic evidence for modern-like plate motion velocities at 3.2 Ga. Science Advances 6, eaaz8670. https://doi.org/10.1126/sciadv.aaz8670

Brown, M., Johnson, T.E., Gardiner, N.J., 2020a. Plate Tectonics and the Archean Earth. Annu. Rev. Earth Planet. Sci. 48, 291-320. https://doi.org/10.1146/annurev-earth-081619-052705

Brown, M., Kirkland, C.L., Johnson, T.E., 2020b. Evolution of geodynamics since the Archean: Significant change at the dawn of the Phanerozoic. Geology 48, 488-492. https://doi.org/10.1130/G47417.1

Brune, S., Williams, S.E., Müller, R.D., 2017. Potential links between continental rifting, CO2 degassing and climate change through time. Nat. Geosci. 10, 941-946. https://doi.org/10.1038/s41561-0170003-6

Burke, K., Torsvik, T.H., 2004. Derivation of Large Igneous Provinces of the past 200 million years from long-term heterogeneities in the deep mantle. Earth Planet. Sci. Lett. 227, 531-538. https://doi.org/10.1016/j.eps1.2004.09.015

Burrett, C., Khin Zaw, Meffre, S., Lai, C.K., Khositanont, S., Chaodumrong, P., Udchachon, M., Ekins, S., Halpin, J., 2014. The configuration of Greater Gondwana-Evidence from LA ICPMS, U-Pb geochronology of detrital zircons from the Palaeozoic and Mesozoic of Southeast Asia and China. 
1919 Burrett, C., Long, J., Stait, B., 1990. Early-Middle Palaeozoic biogeography of Asian terranes derived from Gondwana. Geological Society, London, Memoirs 12, 163-174. https://doi.org/10.1144/GSL.MEM.1990.012.01.14

Caby, R., 2003. Terrane assembly and geodynamic evolution of central-western Hoggar: a synthesis. J. Afr. Earth. Sci. 37, 133-159. https://doi.org/10.1016/j.jafrearsci.2003.05.003

Caby, R., Andreopoulos-Renaud, U., Gravelle, M., 1982. Cadre geologique et geochronologique U/Pb sur zircon des batholites precoces dans le segment pan-africain du Hoggar central (Algerie). Bulletin de la Société Géologique de France S7-XXIV, 677-684. https://doi.org/10.2113/gssgfbull.S7XXIV.4.677

Caby, R., Andreopoulos-Renaud, U., Pin, C., 1989. Late Proterozoic arc-continent and continentcontinent collision in the pan-African trans-Saharan belt of Mali. Can. J. Earth Sci. 26, 11361146. https://doi.org/10.1139/e89-097

Calver, C.R., 2011. Neoproterozoic glacial deposits of Tasmania, in: Arnaud, E., Halverson, G.P., Shields-Zhou, G. (Ed.), The Geological Record of Neoproterozoic Glaciations. Geological Society of London, pp. 649-658. https://doi.org/10.1144/M36.64

Calver, C.R., Everard, J.L., Berry, R.F., Bottrill, R.S., Seymour, D.B., 2014. Proterozoic Tasmania. Geological Evolution of Tasmania: Geological Society of Australia Special Publication 24, 3394.

Calver, C.R., Meffre, S., Everard, J.L., 2013. Felsic Porphyry Sills in Surprise Bay Formation Near Currie, King Island, Dated at 775 Ma (LA-ICPMS, U-Pb on Zircon). Tasmanian Geological Survey.

Cao, W., Williams, S., Flament, N., Zahirovic, S., Scotese, C., Dietmar Müller, R., 2019.

Palaeolatitudinal distribution of lithologic indicators of climate in a palaeogeographic framework. Geol. Mag. 156, 331-354. https://doi.org/10.1017/S0016756818000110

Cawood, P.A., Buchan, C., 2007. Linking accretionary orogenesis with supercontinent assembly. EarthSci. Rev. 82, 217-256. https://doi.org/10.1016/j.earscirev.2007.03.003

Cawood, P.A., Hawkesworth, C.J., Dhuime, B., 2013a. The continental record and the generation of continental crust. GSA Bulletin 125, 14-32. https://doi.org/10.1130/B30722.1

Cawood, P.A., Hawkesworth, C.J., Pisarevsky, S.A., Dhuime, B., Capitanio, F.A., Nebel, O., 2018a. Geological archive of the onset of plate tectonics. Philos. Trans. A Math. Phys. Eng. Sci. 376. https://doi.org/10.1098/rsta.2017.0405

Cawood, P.A., Nemchin, A.A., Leverenz, A., Saeed, A., Balance, P.F., 1999. U/Pb dating of detrital zircons: Implications for the provenance record of Gondwana margin terranes. GSA Bulletin 111, 
Cawood, P.A., Nemchin, A.A., Smith, M., Loewy, S., 2003. Source of the Dalradian Supergroup constrained by $\mathrm{U}-\mathrm{Pb}$ dating of detrital zircon and implications for the East Laurentian margin. J. Geol. Soc. London 160, 231-246. https://doi.org/10.1144/0016-764902-039

1956

Cawood, P.A., Pisarevsky, S.A., 2006. Was Baltica right-way-up or upside-down in the Neoproterozoic? J. Geol. Soc. London 163, 753-759. https://doi.org/10.1144/0016-76492005-126

Cawood, P.A., Strachan, R., Cutts, K., Kinny, P.D., Hand, M., Pisarevsky, S., 2010. Neoproterozoic orogeny along the margin of Rodinia: Valhalla orogen, North Atlantic. Geology 38, 99-102. https://doi.org/10.1130/G30450.1

Cawood, P.A., Strachan, R.A., Pisarevsky, S.A., Gladkochub, D.P., Murphy, J.B., 2016. Linking collisional and accretionary orogens during Rodinia assembly and breakup: Implications for models of supercontinent cycles. Earth Planet. Sci. Lett. 449, 118-126. https://doi.org/10.1016/j.epsl.2016.05.049

Cawood, P.A., Wang, W., Zhao, T., Xu, Y., Mulder, J.A., Pisarevsky, S.A., Zhang, L., Gan, C., He, H., Liu, H., Qi, L., Wang, Y., Yao, J., Zhao, G., Zhou, M.-F., Zi, J.-W., 2020. Deconstructing South China and consequences for reconstructing Nuna and Rodinia. Earth-Sci. Rev. 204, 103169. https://doi.org/10.1016/j.earscirev.2020.103169

Cawood, P.A., Wang, Y., Xu, Y., Zhao, G., 2013b. Locating South China in Rodinia and Gondwana: A fragment of greater India lithosphere? Geology 41, 903-906. https://doi.org/10.1130/G34395.1

Cawood, P.A., Zhao, G., Yao, J., Wang, W., Xu, Y., Wang, Y., 2018b. Reconstructing South China in Phanerozoic and Precambrian supercontinents. Earth-Sci. Rev. 186, 173-194. https://doi.org/10.1016/j.earscirev.2017.06.001

Caxito, F. de A., Uhlein, A., Dantas, E.L., 2014a. The Afeição augen-gneiss Suite and the record of the Cariris Velhos Orogeny (1000-960 Ma) within the Riacho do Pontal fold belt, NE Brazil. J. South Amer. Earth Sci. 51, 12-27. https://doi.org/10.1016/j.jsames.2013.12.012

Caxito, F. de A., Uhlein, A., Stevenson, R., Uhlein, G.J., 2014b. Neoproterozoic oceanic crust remnants in northeast Brazil. Geology 42, 387-390. https://doi.org/10.1130/G35479.1

Caxito, F.A., Uhlein, A., Dantas, E.L., Stevenson, R., Salgado, S.S., Dussin, I.A., Sial, A. da N., 2016. A complete Wilson Cycle recorded within the Riacho do Pontal Orogen, NE Brazil: Implications for the Neoproterozoic evolution of the Borborema Province at the heart of West Gondwana. Precambrian Res. 282, 97-120. https://doi.org/10.1016/j.precamres.2016.07.001

Cayley, R.A., 2011. Exotic crustal block accretion to the eastern Gondwanaland margin in the Late Cambrian--Tasmania, the Selwyn Block, and implications for the Cambrian--Silurian evolution of the Ross, Delamerian, and Lachlan orogens. Gondwana Res. 19, 628-649. 
1986

1987

1988

1989

1990

1991

1992

1993

1994

1995

1996

1997

1998

1999

2000

2001

2002

2003

2004

2005

2006

2007

2008

2009

2010

2011

2012

2013

2014

2015

2016

2017

2018

2019

Channell, J.E.T., McCabe, C., 1992. Palaeomagnetic data from the Borrowdale Volcanic Group: volcanotectonics and Late Ordovician palaeolatitudes. J. Geol. Soc. London 149, 881-888. https://doi.org/10.1144/gsjgs.149.6.0881

Channell, J.E.T., McCabe, C., Woodcock, N.H., 1993. Palaeomagnetic study of Llandovery (Lower Silurian) red beds in north-west England. Geophys. J. Int. 115, 1085-1094.

Charvet, J., Shu, L., Laurent-Charvet, S., Wang, B., Faure, M., Cluzel, D., Chen, Y., De Jong, K., 2011. Palaeozoic tectonic evolution of the Tianshan belt, NW China. Sci. China Earth Sci. 54, 166-184. https://doi.org/10.1007/s11430-010-4138-1

Chen, Y., Xu, B., Zhan, S., Li, Y., 2004. First mid-Neoproterozoic paleomagnetic results from the Tarim Basin (NW China) and their geodynamic implications. Precambrian Res. 133, 271-281. https://doi.org/10.1016/j.precamres.2004.05.002

Claesson, C., 1979. Early Palaeozoic geomagnetism of Gotland. Geologiska Föreningen i Stockholm Förhandlingar 101, 149-155. https://doi.org/10.1080/11035897909452573

Clennett, E.J., Sigloch, K., Mihalynuk, M.G., Seton, M., Henderson, M.A., Hosseini, K., Mohammadzaheri, A., Johnston, S.T., Müller, R.D., 2020. A Quantitative Tomotectonic Plate Reconstruction of Western North America and the Eastern Pacific Basin. Geochem. Geophys. Geosyst., Geological Association of Canada Special Paper 21, 2011-11. https://doi.org/10.1029/2020GC009117

Cocks, L.R.M., Fortey, R.A., 1997. A new Hirnantia faunafrom Thailand and the biogeography of the latest Ordovician of south-east Asia. Geobios Mem. Spec. 30, 117-126. https://doi.org/10.1016/S0016-6995(97)80017-4

Cocks, L.R.M., Torsvik, T.H., 2007. Siberia, the wandering northern terrane, and its changing geography through the Palaeozoic. Earth-Sci. Rev. 82, 29-74. https://doi.org/10.1016/j.earscirev.2007.02.001

Collins, A.S., 2006. Madagascar and the amalgamation of Central Gondwana. Gondwana Res. 9, 3-16. https://doi.org/10.1016/j.gr.2005.10.001

Collins, A.S., 2003. Structure and age of the northern Leeuwin Complex, Western Australia: Constraints from field mapping and U-Pb isotopic analysis. Aust. J. Earth Sci. 50, 585-599. https://doi.org/10.1046/j.1440-0952.2003.01014.x

Collins, A.S., Blades, M.L., Merdith, A.S., Foden, J.D., in revision. A late Tonian plate reorganization event revealed by a full-plate Proterozoic reconstruction. Communications Earth and Environment.

Collins, A.S., Kröner, A., Fitzsimons, I.C.W., Razakamanana, T., 2003. Detrital footprint of the Mozambique ocean: $\mathrm{U}-\mathrm{Pb}$ SHRIMP and $\mathrm{Pb}$ evaporation zircon geochronology of 
metasedimentary gneisses in eastern Madagascar. Tectonophysics 375, 77-99. https://doi.org/10.1016/S0040-1951(03)00334-2

Collins, A.S., Pisarevsky, S.A., 2005. Amalgamating eastern Gondwana: The evolution of the CircumIndian Orogens. Earth-Sci. Rev. 71, 229-270. https://doi.org/10.1016/j.earscirev.2005.02.004

Collins, W.J., Belousova, E.A., Kemp, A.I.S., Murphy, J.B., 2011. Two contrasting Phanerozoic orogenic systems revealed by hafnium isotope data. Nat. Geosci. 4, 333-337. https://doi.org/10.1038/ngeo1 127

Colpron, M., Logan, J.M., Mortensen, J.K., 2002. U-Pb zircon age constraint for late Neoproterozoic rifting and initiation of the lower Paleozoic passive margin of western Laurentia. Can. J. Earth Sci. 39, 133-143.

Compston, W., Wright, A.E., Toghill, P., 2002. Dating the Late Precambrian volcanicity of England and Wales. J. Geol. Soc. London 159, 323-339. https://doi.org/10.1144/0016-764901-010

Corvino, A.F., Boger, S.D., Henjes-Kunst, F., Wilson, C.J.L., Fitzsimons, I.C.W., 2008. Superimposed tectonic events at $2450 \mathrm{Ma}, 2100 \mathrm{Ma}, 900 \mathrm{Ma}$ and $500 \mathrm{Ma}$ in the North Mawson Escarpment, Antarctic Prince Charles Mountains. Precambrian Res. 167, 281-302.

Cox, G.M., Halverson, G.P., Denyszyn, S., Foden, J., Macdonald, F.A., 2018. Cryogenian magmatism along the north-western margin of Laurentia: Plume or rift? Precambrian Res. 319, 144-157. https://doi.org/10.1016/j.precamres.2017.09.025

da Silva Filho, A.F., Guimarães, I.P., Van Schmus, W.R., 2002. Crustal Evolution of the PernambucoAlagoas Complex, Borborema Province, NE Brazil: Nd Isotopic Data from Neoproterozoic Granitoids. Gondwana Res. 5, 409-422. https://doi.org/10.1016/S1342-937X(05)70732-2

Daczko, N.R., Halpin, J.A., Fitzsimons, I.C.W., Whittaker, J.M., 2018. A cryptic Gondwana-forming orogen located in Antarctica. Sci. Rep. 8, 8371. https://doi.org/10.1038/s41598-018-26530-1

Dallmeyer, R.D., 1989. Contrasting accreted terranes in the southern Appalachian Orogen, basement beneath the Atlantic and Gulf Coastal Plains, and West African orogens. Precambrian Res. 42, 387-409. https://doi.org/10.1016/0301-9268(89)90021-1

Dalziel, I.W., 1992. On the organization of American plates in the Neoproterozoic and the breakout of Laurentia. GSA Today 2.

Dalziel, I.W.D., 1997. Neoproterozoic-Paleozoic geography and tectonics: Review, hypothesis, environmental speculation. GSA Bulletin 109, 16-42. 2.3.CO;2">https://doi.org/10.1130/00167606(1997)109<0016:ONPGAT>2.3.CO;2

Dalziel, I.W.D., 1991. Pacific margins of Laurentia and East Antarctica-Australia as a conjugate rift pair: Evidence and implications for an Eocambrian supercontinent. Geology 19, 598-601.

Dalziel, I.W.D., Dewey, J.F., 2019. The classic Wilson cycle revisited. Geological Society, London, 
Special Publications 470, 19-38. https://doi.org/10.1144/SP470.1

Danukalov, N.F., Kondruchina, L.S., Chernikov, A.P., 1983. Paleozoic paleomagnetism of the South and Central Urals. BF AN SSSR, Ufa.

Davies, D.R., Goes, S., Sambridge, M., 2015. On the relationship between volcanic hotspot locations, the reconstructed eruption sites of large igneous provinces and deep mantle seismic structure. Earth Planet. Sci. Lett. 411, 121-130. https://doi.org/10.1016/j.epsl.2014.11.052

Davies, R.G., Crawford, A.R., 1971. Petrography and age of the rocks of Bulland Hill, Kirana Hills, Sarghoda District, West Pakistan. Geol. Mag. 108, 235-246. https://doi.org/10.1017/S001675680005158X

Davis, J.K., Meert, J.G., Pandit, M.K., 2014. Paleomagnetic analysis of the Marwar Supergroup, Rajasthan, India and proposed interbasinal correlations. J. Asian Earth Sci. 91, 339-351. https://doi.org/10.1016/j.jseaes.2013.09.027

Deb, M., Thorpe, R.I., Krstic, D., Corfu, F., Davis, D.W., 2001. Zircon U-Pb and galena Pb isotope evidence for an approximate $1.0 \mathrm{Ga}$ terrane constituting the western margin of the Aravalli-Delhi orogenic belt, northwestern India. Precambrian Res. 108, 195-213. https://doi.org/10.1016/S0301-9268(01)00134-6

Degtyarev, K., Yakubchuk, A., Tretyakov, A., Kotov, A., Kovach, V., 2017. Precambrian geology of the Kazakh Uplands and Tien Shan: An overview. Gondwana Res. 47, 44-75. https://doi.org/10.1016/j.gr.2016.12.014

Degtyarev, K.E., 2011. Tectonic evolution of Early Paleozoic island-arc systems and continental crust formation in the Caledonides of Kazakhstan and the North Tien Shan. Geotectonics/Geotektonika 45, 23-50. https://doi.org/10.1134/S0016852111010031

Degtyarev, K.E., Shatagin, K.N., Kotov, A.B., Sal’Nikova, E.B., Luchitskaya, M.V., Tret’yakov, A.A., Yakovleva, S.Z., 2008. Late Precambrian volcanoplutonic association of the Aktau-Dzhungar massif, Central Kazakhstan: Structural position and age, in: Doklady Earth Sciences. Springer Nature BV, p. 879.

Degtyarev, K.E., Tret'yakov, A.A., Ryazantsev, A.V., Kotov, A.B., Sal'nikova, E.B., Aleksandrov, P.A., Anisimova, I.V., 2011. Stenian granitoids of the west Kyrgyz Ridge (North Tien Shan): Position, structure, and age determination. Dokl. Earth Sci. 441, 1484-1488. https://doi.org/10.1134/S1028334X11110134

Denyszyn, S.W., Halls, H.C., Davis, D.W., Evans, D.A.D., 2009. Paleomagnetism and U-Pb geochronology of Franklin dykes in High Arctic Canada and Greenland: a revised age and paleomagnetic pole constraining block rotations in the Nares Strait region. Can. J. Earth Sci. 46, 689-705. https://doi.org/10.1139/E09-042 
Deutsch, E.R., 1980. Magnetism of the Mid-Ordovician Tramore Volcanics, SE Ireland, and the Question of a Wide Proto-Atlantic Ocean. J. Geomagn. Geoelectr. 32, SIII77-SIII98. https://doi.org/10.5636/jgg.32.Supplement3_SIII77

Deutsch, E.R., Prasad, J.N., 1987. Ordovician paleomagnetic results from the St. George and Table Head carbonates of western Newfoundland. Can. J. Earth Sci. 24, 1785-1796. https://doi.org/10.1139/e87-170

Direen, N.G., Crawford, A.J., 2003. Fossil seaward-dipping reflector sequences preserved in southeastern Australia: a 600 Ma volcanic passive margin in eastern Gondwanaland. J. Geol. Soc. London 160, 985-990. https://doi.org/10.1144/0016-764903-010

Doig, R., Murphy, J.B., Nance, R.D., 1993. Tectonic significance of the Late Proterozoic Economy River gneiss, Cobequid Highlands, Avalon Composite Terrane, Nova Scotia. Can. J. Earth Sci. 30, 474479. https://doi.org/10.1139/e93-035

Domeier, M., 2018. Early Paleozoic tectonics of Asia: Towards a full-plate model. Geoscience Frontiers 9, 789-862. https://doi.org/10.1016/j.gsf.2017.11.012

Domeier, M., 2016. A plate tectonic scenario for the Iapetus and Rheic oceans. Gondwana Res. 36, 275295. https://doi.org/10.1016/j.gr.2015.08.003

Domeier, M., Font, E., Youbi, N., Davies, J., Nemkin, S., Van der Voo, R., Perrot, M., Benabbou, M., Boumehdi, M.A., Torsvik, T.H., 2020. On the Early Permian shape of Pangea from paleomagnetism at its core. Gondwana Res. https://doi.org/10.1016/j.gr.2020.11.005

Domeier, M., Shephard, G.E., Jakob, J., Gaina, C., Doubrovine, P.V., Torsvik, T.H., 2017. Intraoceanic subduction spanned the Pacific in the Late Cretaceous-Paleocene. Sci Adv 3. https://doi.org/10.1126/sciadv.aao2303

Domeier, M., Torsvik, T.H., 2017. Full-plate modelling in pre-Jurassic time. Geol. Mag. 1-20. https://doi.org/10.1017/S0016756817001005

Domeier, M., Torsvik, T.H., 2014. Plate tectonics in the late Paleozoic. Geoscience Frontiers 5, 303-350. https://doi.org/10.1016/j.gsf.2014.01.002

Domeier, M., Van der Voo, R., Torsvik, T.H., 2012. Paleomagnetism and Pangea: The road to reconciliation. Tectonophysics 514-517, 14-43. https://doi.org/10.1016/j.tecto.2011.10.021

Dong, Y., Santosh, M., 2016. Tectonic architecture and multiple orogeny of the Qinling Orogenic Belt, Central China. Gondwana Res. 29, 1-40. https://doi.org/10.1016/j.gr.2015.06.009

Dong, Y., Yang, Z., Liu, X., Zhang, X., He, D., Li, W., Zhang, F., Sun, S., Zhang, H., Zhang, G., 2014. Neoproterozoic amalgamation of the Northern Qinling terrain to the North China Craton: Constraints from geochronology and geochemistry of the Kuanping ophiolite. Precambrian Res. 255, 77-95. https://doi.org/10.1016/j.precamres.2014.09.008 
dos Santos, E.J., Van Schmus, W.R., Kozuch, M., Neves, B.B. de B., 2010. The Cariris Velhos tectonic event in Northeast Brazil. J. South Amer. Earth Sci. 29, 61-76. https://doi.org/10.1016/j.jsames.2009.07.003

Doubrovine, P.V., Steinberger, B., Torsvik, T.H., 2016. A failure to reject: Testing the correlation between large igneous provinces and deep mantle structures with EDF statistics. Geochem. Geophys. Geosyst. 17, 1130-1163.

Doucet, L.S., Li, Z.-X., Gamal El Dien, H., Pourteau, A., Murphy, J.B., Collins, W.J., Mattielli, N., Olierook, H.K.H., Spencer, C.J., Mitchell, R.N., 2020. Distinct formation history for deep-mantle domains reflected in geochemical differences. Nat. Geosci. 13, 511-515. https://doi.org/10.1038/s41561-020-0599-9

Douglass, D.N., 1988. Paleomagnetics of Ringerike Old Red Sandstone and related rocks, southern Norway: implications for pre-Carboniferous separation of Baltica and British terranes. Tectonophysics 148, 11-27. https://doi.org/10.1016/0040-1951(88)90157-6

Dunn, W.J., Elmore, R.D., 1985. Paleomagnetic and petrographic investigation of the Taum Sauk Limestone, southeast Missouri. J. Geophys. Res., Geodyn. Ser. 90, 11469. https://doi.org/10.1029/JB090iB13p11469

Dutkiewicz, A., Dietmar Müller, R., Cannon, J., Vaughan, S., Zahirovic, S., 2019. Sequestration and subduction of deep-sea carbonate in the global ocean since the Early Cretaceous. Geology 47, 9194. https://doi.org/10.1130/G45424.1

Elburg, M.A., Andersen, T., Jacobs, J., Läufer, A., Ruppel, A., Krohne, N., Damaske, D., 2015. One Hundred Fifty Million Years of Intrusive Activity in the Sør Rondane Mountains (East Antarctica): Implications for Gondwana Assembly. J. Geol. https://doi.org/10.1086/684052

Elming, S.-Å., Pisarevsky, S.A., Layer, P., Bylund, G., 2014. A palaeomagnetic and 40Ar/39Ar study of mafic dykes in southern Sweden: A new Early Neoproterozoic key-pole for the Baltic Shield and implications for Sveconorwegian and Grenville loops. Precambrian Res. 244, 192-206. https://doi.org/10.1016/j.precamres.2013.12.007

Elston, D.P., Bressler, S.L., 1977. Paleomagnetic poles and polarity zonation from Cambrian and Devonian strata of Arizona. Earth Planet. Sci. Lett. 36, 423-433. https://doi.org/10.1016/0012$821 \mathrm{X}(77) 90067-\mathrm{X}$

Embleton, B.J.J., Williams, G.E., 1986. Low palaeolatitude of deposition for late Precambrian periglacial varvites in South Australia: implications for palaeoclimatology. Earth Planet. Sci. Lett. 79, 419430. https://doi.org/10.1016/0012-821X(86)90197-4

England, P., Molnar, P., 1990. Surface uplift, uplift of rocks, and exhumation of rocks. Geology 18, 1173-1177. 2.3.CO;2">https://doi.org/10.1130/0091-7613(1990)018<1173:SUUORA >2.3.CO;2 
Evans, D., 2003. True polar wander and supercontinents. Tectonophysics. https://doi.org/10.1016/S00401951(02)00642-X

Evans, D.A.D., 2013. Reconstructing pre-Pangean supercontinents. Bull. Am. Assoc. Hist. Nurs.

Evans, D.A.D., 2009. The palaeomagnetically viable, long-lived and all-inclusive Rodinia supercontinent reconstruction. Geological Society, London, Special.

Evans, D.A.D., Li, Z.X., Kirschvink, J.L., Wingate, M.T.D., 2000. A high-quality mid-Neoproterozoic paleomagnetic pole from South China, with implications for ice ages and the breakup configuration of Rodinia. Precambrian Res. 100, 313-334. https://doi.org/10.1016/S03019268(99)00079-0

Evans, D.A.D., Trindade, R.I.F., Catelani, E.L., D’Agrella-Filho, M.S., Heaman, L.M., Oliveira, E.P., Söderlund, U., Ernst, R.E., Smirnov, A.V., Salminen, J.M., 2016. Return to Rodinia? Moderate to high palaeolatitude of the São Francisco/Congo craton at 920 Ma. Geological Society, London, Special Publications 424, 167-190. https://doi.org/10.1144/SP424.1

Eyster, A., Weiss, B.P., Karlstrom, K., Macdonald, F.A., 2019. Paleomagnetism of the Chuar Group and evaluation of the late Tonian Laurentian apparent polar wander path with implications for the makeup and breakup of Rodinia. GSA Bulletin. https://doi.org/10.1130/B32012.1

Fang, D., Wang, P., Shen, Z., Tan, X., 1998. Cenozoic paleomagnetic results and phanerozoic apparent polar wandering path of Tarim Block. Sci. China Ser. D Earth Sci.

Fang, D.-J., Jin, G.-H., Jiang, L.-P., Wang, P.-Y., Wang, Z.-L., 1996. Paleozoic paleomagnetic results and the tectonic significance of Tarim Plate. Acta Geophysica Sinica 39, 532-542.

Farr, M.R., Gose, W.A., 1991. Paleomagnetism of the Cambrian Moore Hollow Group, Texas: Evidence for a primary magnetization carried by detrital magnetite. J. Geophys. Res. 96, 9895. https://doi.org/10.1029/91JB00337

Fezaa, N., Liégeois, J.-P., Abdallah, N., Cherfouh, E.H., De Waele, B., Bruguier, O., Ouabadi, A., 2010. Late Ediacaran geological evolution (575-555 Ma) of the Djanet Terrane, Eastern Hoggar, Algeria, evidence for a Murzukian intracontinental episode. Precambrian Res. 180, 299-327.

Fioretti, A.M., Black, L.P., Foden, J., Visonà, D., 2005. Grenville-age magmatism at the South Tasman Rise (Australia): A new piercing point for the reconstruction of Rodinia. Geology 33, 769-772. https://doi.org/10.1130/G21671.1

Fitzsimons, I.C.W., 2003. Proterozoic basement provinces of southern and southwestern Australia, and their correlation with Antarctica. Geological Society, London, Special Publications 206, 93-130. https://doi.org/10.1144/GSL.SP.2003.206.01.07

Flament, N., Williams, S., Müller, R.D., Gurnis, M., Bower, D.J., 2017. Origin and evolution of the deep thermochemical structure beneath Eurasia. Nat. Commun. 8, 14164. 
https://doi.org/10.1038/ncomms14164

French, A.N., Van der Voo, R., 1979. The magnetization of the Rose Hill Formation at the classical site of Graham's Fold Test. J. Geophys. Res. 84, 7688-7696. https://doi.org/10.1029/JB084iB13p07688

Fu, X., Zhang, S., Li, Haiyan, Ding, J., Li, Huaikun, Yang, T., Wu, H., Yuan, H., Lv, J., 2015. New paleomagnetic results from the Huaibei Group and Neoproterozoic mafic sills in the North China Craton and their paleogeographic implications. Precambrian Res. 269, 90-106. https://doi.org/10.1016/j.precamres.2015.08.013

Furnes, H., de Wit, M., Dilek, Y., 2014. Four billion years of ophiolites reveal secular trends in oceanic crust formation. Geoscience Frontiers 5, 571-603. https://doi.org/10.1016/j.gsf.2014.02.002

Gallet, Y., Pavlov, V., 1996. Magnetostratigraphy of the Moyero River Section (North-Western Siberia): Constraints On Geomagnetic Reversal Frequency During the Early Palaeozoic. Geophys. J. Int. 125, 95-105. https://doi.org/10.1111/j.1365-246X.1996.tb06536.x

Gallet, Y., Pavlov, V., Courtillot, V., 2003. Magnetic reversal frequency and apparent polar wander of the Siberian platform in the earliest Palaeozoic, inferred from the Khorbusuonka river section (northeastern Siberia). Geophys. J. Int. 154, 829-840.

Ganade de Araujo, C.E., Cordani, U.G., Weinberg, R.F., Basei, M.A.S., Armstrong, R., Sato, K., 2014. Tracing Neoproterozoic subduction in the Borborema Province (NE-Brazil): Clues from U-Pb geochronology and Sr-Nd-Hf-O isotopes on granitoids and migmatites. Lithos 202-203, 167189. https://doi.org/10.1016/j.lithos.2014.05.015

Gao, J., Wang, X.-S., Klemd, R., Jiang, T., Qian, Q., Mu, L.-X., Ma, Y.-Z., 2015. Record of assembly and breakup of Rodinia in the Southwestern Altaids: Evidence from Neoproterozoic magmatism in the Chinese Western Tianshan Orogen. J. Asian Earth Sci. 113, 173-193. https://doi.org/10.1016/j.jseaes.2015.02.002

Gao, R.F., Huang, H.L., Zhu, Z.W., Liu, H.S., Fan, Y.Q., Qing, X.J., 1983. The study of paleomagnetism in northeastern Sino-Korean massif during Pre-late Paleozoic. Contr. Project of Plate Tectonics in North China 1, 265-274.

Garnero, E.J., Lay, T., McNamara, A., 2007. Implications of lower-mantle structural heterogeneity for the existence and nature of whole-mantle plumes. Special Papers-Geological Society of America 430, 79.

Ge, R., Zhu, W., Wilde, S.A., He, J., Cui, X., Wang, X., Bihai, Z., 2014. Neoproterozoic to Paleozoic long-lived accretionary orogeny in the northern Tarim Craton: accretionary orogeny in northern Tarim. Tectonics 33, 302-329. https://doi.org/10.1002/2013TC003501

Geissman, J.W., Jackson, M., Harlan, S.S., Van Der Voo, R., 1991. Paleomagnetism of Latest Cambrian- 
Early Ordovician and Latest Cretaceous-Early Tertiary rocks of the Florida Mountains, southwest New Mexico. J. Geophys. Res. [Solid Earth] 96, 6053-6071.

Gernon, T.M., Hincks, T.K., Tyrrell, T., Rohling, E.J., Palmer, M.R., 2016. Snowball Earth ocean chemistry driven by extensive ridge volcanism during Rodinia breakup. Nat. Geosci. 9, 242. https://doi.org/10.1038/ngeo2632

Gerya, T., 2014. Precambrian geodynamics: Concepts and models. Gondwana Res. 25, 442-463. https://doi.org/10.1016/j.gr.2012.11.008

Goddéris, Y., Le Hir, G., Macouin, M., Donnadieu, Y., Hubert-Théou, L., Dera, G., Aretz, M., Fluteau, F., Li, Z.X., Halverson, G.P., 2017. Paleogeographic forcing of the strontium isotopic cycle in the Neoproterozoic. Gondwana Res. 42, 151-162. https://doi.org/10.1016/j.gr.2016.09.013

Goodge, J.W., Fanning, C.M., Fisher, C.M., Vervoort, J.D., 2017. Proterozoic crustal evolution of central East Antarctica: Age and isotopic evidence from glacial igneous clasts, and links with Australia and Laurentia. Precambrian Res. 299, 151-176. https://doi.org/10.1016/j.precamres.2017.07.026

Gordon, R.G., Cox, A., O’Hare, S., 1984. Paleomagnetic Euler poles and the apparent polar wander and absolute motion of North America since the Carboniferous. Tectonics 3, 499-537. https://doi.org/10.1029/TC003i005p00499

Granot, R., 2016. Palaeozoic oceanic crust preserved beneath the eastern Mediterranean. Nat. Geosci. 9, 701-705. https://doi.org/10.1038/ngeo2784

Gregory, L.C., Meert, J.G., Bingen, B., Pandit, M.K., Torsvik, T.H., 2009. Paleomagnetism and geochronology of the Malani Igneous Suite, Northwest India: Implications for the configuration of Rodinia and the assembly of Gondwana. Precambrian Res. 170, 13-26. https://doi.org/10.1016/j.precamres.2008.11.004

Guimarães, I.P., Van Schmus, W.R., de Brito Neves, B.B., Bretas Bittar, S.M., Silva Filho, A.F., Armstrong, R., 2012. U-Pb zircon ages of orthogneisses and supracrustal rocks of the Cariris Velhos belt: Onset of Neoproterozoic rifting in the Borborema Province, NE Brazil. Precambrian Res. 192-195, 52-77. https://doi.org/10.1016/j.precamres.2011.10.008

Gurnis, M., Turner, M., Zahirovic, S., DiCaprio, L., Spasojevic, S., Müller, R.D., Boyden, J., Seton, M., Manea, V.C., Bower, D.J., 2012. Plate tectonic reconstructions with continuously closing plates. Comput. Geosci. 38, 35-42. https://doi.org/10.1016/j.cageo.2011.04.014

Gurnis, M., Yang, T., Cannon, J., Turner, M., Williams, S., Flament, N., Müller, R.D., 2018. Global tectonic reconstructions with continuously deforming and evolving rigid plates. Comput. Geosci. 116, 32-41. https://doi.org/10.1016/j.cageo.2018.04.007

Guynn, J., Kapp, P., Gehrels, G.E., Ding, L., 2012. U-Pb geochronology of basement rocks in central Tibet and paleogeographic implications. J. Asian Earth Sci. 43, 23-50. 
https://doi.org/10.1016/j.jseaes.2011.09.003

Guynn, J.H., Kapp, P., Pullen, A., Heizler, M., Gehrels, G., Ding, L., 2006. Tibetan basement rocks near Amdo reveal "missing" Mesozoic tectonism along the Bangong suture, central Tibet. Geology 34, 505-508. https://doi.org/10.1130/G22453.1

Hadj-Kaddour, Z., Liégeois, J.-P., Demaiffe, D., Caby, R., 1998. The alkaline-peralkaline granitic postcollisional Tin Zebane dyke swarm (Pan-African Tuareg shield, Algeria): prevalent mantle signature and late agpaitic differentiation. Lithos 45, 223-243. https://doi.org/10.1016/S00244937(98)00033-4

Haldar, S.K., Deb, M., 2001. Geology and mineralization of Rajpura-Dariba lead-zinc belt, Rajasthan, in: Deb, M., Goodfellow, W.D. (Eds.), Sediment-Hosted Lead-Zink Deposit Modeling Program. Delhi-Udaipur, Elsevier, New Dehli, pp. 177-187.

Hall, S.A., Evans, I., 1988. Paleomagnetic study of the Ordovician Table Head Group, Port au Port Peninsula, Newfoundland. Can. J. Earth Sci. 25, 1407-1419. https://doi.org/10.1139/e88-135

Halpin, J.A., Daczko, N.R., Kobler, M.E., Whittaker, J.M., 2017. Strike-slip tectonics during the Neoproterozoic-Cambrian assembly of East Gondwana: Evidence from a newly discovered microcontinent in the Indian Ocean .... Gondwana Res.

Halpin, J.A., Jensen, T., McGoldrick, P., Meffre, S., Berry, R.F., Everard, J.L., Calver, C.R., Thompson, J., Goemann, K., Whittaker, J.M., 2014. Authigenic monazite and detrital zircon dating from the Proterozoic Rocky Cape Group, Tasmania: Links to the Belt-Purcell Supergroup, North America. Precambrian Res. 250, 50-67. https://doi.org/10.1016/j.precamres.2014.05.025

Hamilton, M.A., Murphy, J.B., 2004. Tectonic significance of a Llanvirn age for the Dunn Point volcanic rocks, Avalon terrane, Nova Scotia, Canada: implications for the evolution of the Iapetus and Rheic Oceans. Tectonophysics 379, 199-209. https://doi.org/10.1016/j.tecto.2003.11.006

Han, Z., Yang, Z., Tong, Y., Jing, X., 2015. New paleomagnetic results from Late Ordovician rocks of the Yangtze Block, South China, and their paleogeographic implications. J. Geophys. Res. [Solid Earth] 120, 4759-4772.

Handke, M.J., Tucker, R.D., Ashwal, L.D., 1999. Neoproterozoic continental arc magmatism in westcentral Madagascar. Geology 27, 351-354. 2.3.CO;2">https://doi.org/10.1130/00917613(1999)027<0351:NCAMIW>2.3.CO;2

Hargraves, R.B., Dawson, E.M., Houten, F.B., 1987. Palaeomagnetism and age of mid-Palaeozoic ring complexes in Niger, West Africa, and tectonic implications. Geophys. J. Int. 90, 705-729. https://doi.org/10.1111/j.1365-246X.1987.tb00750.x

Harlan, S.S., Geissman, J.W., Snee, L.W., 2008. Paleomagnetism of Proterozoic mafic dikes from the Tobacco Root Mountains, southwest Montana. Precambrian Res. 163, 239-264. 
https://doi.org/10.1016/j.precamres.2007.12.002

Hartz, E.H., Torsvik, T.H., 2002. Baltica upside down: A new plate tectonic model for Rodinia and the Iapetus Ocean. Geology 30, 255-258. 2.0.CO;2">https://doi.org/10.1130/00917613(2002)030<0255:BUDANP>2.0.CO;2

He, T., Zhu, M., Mills, B.J.W., Wynn, P.M., Zhuravlev, A.Y., Tostevin, R., Pogge von Strandmann, P.A.E., Yang, A., Poulton, S.W., Shields, G.A., 2019. Possible links between extreme oxygen perturbations and the Cambrian radiation of animals. Nat. Geosci. 12, 468-474. https://doi.org/10.1038/s41561-019-0357-z

Heatherington, A.L., Mueller, P.A., Nutman, A.P., 1996. Neoproterozoic magmatism in the Suwannee terrane: Implications for terrane correlation. Geological Society of America Special Papers 304, $257-268$.

Henry, B., Liégeois, J.P., Nouar, O., Derder, M.E.M., Bayou, B., Bruguier, O., Ouabadi, A., Belhai, D., Amenna, M., Hemmi, A., Ayache, M., 2009. Repeated granitoid intrusions during the Neoproterozoic along the western boundary of the Saharan metacraton, Eastern Hoggar, Tuareg shield, Algeria: An AMS and U-Pb zircon age study. Tectonophysics 474, 417-434. https://doi.org/10.1016/j.tecto.2009.04.022

Heron, P.J., Murphy, J.B., Nance, D.R., Pysklywec, R.N., 2020. Pannotia's mantle signature: the quest for supercontinent identification. Geological Society, London, Special Publications 503. https://doi.org/10.1144/SP503-2020-7

Hibbard, J.P., van Staal, C.R., Miller, B.V., 2007. Links among Carolinia, Avalonia, and Ganderia in the Appalachian peri-Gondwanan realm. Geological Society of America Special Papers 433, 291311.

Hochmuth, K., Gohl, K., Uenzelmann-Neben, G., 2015. Playing jigsaw with large igneous provinces-A plate tectonic reconstruction of Ontong Java Nui, West Pacific. Geochem. Geophys. Geosyst. 16, 3789-3807.

Hodych, J.P., 1989. Limestones of western Newfoundland that magnetized before Devonian folding but after Middle Ordovician lithification. Geophys. Res. Lett. 16, 93-96. https://doi.org/10.1029/GL016i001p00093

Hodych, J.P., Buchan, K.L., 1998. Palaeomagnetism of the ca. 440 Ma Cape St Mary's sills of the Avalon Peninsula of Newfoundland: implications for Iapetus Ocean closure. Geophys. J. Int. 135, 155164. https://doi.org/10.1046/j.1365-246X.1998.00263.X

Hodych, J.P., Cox, R.A., Košler, J., 2004. An equatorial Laurentia at 550 Ma confirmed by Grenvillian inherited zircons dated by LAM ICP-MS in the Skinner Cove volcanics of western Newfoundland: implications for inertial interchange true polar wander. Precambrian Res. 129, 
Hoffman, P.F., 1991. Did the breakout of Laurentia turn Gondwanaland inside-out? Science 252, 14091412. https://doi.org/10.1126/science.252.5011.1409

Hoffman, P.F., Kaufman, A.J., Halverson, G.P., Schrag, D.P., 1998. A Neoproterozoic snowball earth. Science 281, 1342-1346. https://doi.org/10.1126/science.281.5381.1342

Hoffman, P.F., Schrag, D.P., 2002. The snowball Earth hypothesis: testing the limits of global change. Terra Nova 14, 129-155. https://doi.org/10.1046/j.1365-3121.2002.00408.x

Hofmann, M., Linnemann, U., Rai, V., Becker, S., Gärtner, A., Sagawe, A., 2011. The India and South China cratons at the margin of Rodinia-Synchronous Neoproterozoic magmatism revealed by LA-ICP-MS zircon analyses. Lithos 123, 176-187.

Hopper, E., Fischer, K.M., Wagner, L.S., Hawman, R.B., 2017. Reconstructing the end of the Appalachian orogeny. Geology 45, 15-18. https://doi.org/10.1130/G38453.1

Hounslow, M.W., Domeier, M., Biggin, A.J., 2018. Subduction flux modulates the geomagnetic polarity reversal rate. Tectonophysics 742-743, 34-49. https://doi.org/10.1016/j.tecto.2018.05.018

Hu, P.-Y., Zhai, Q.-G., Wang, J., Tang, Y., Wang, H.-T., Hou, K.-J., 2018. Precambrian origin of the North Lhasa terrane, Tibetan Plateau: Constraint from early Cryogenian back-arc magmatism. Precambrian Res. 313, 51-67. https://doi.org/10.1016/j.precamres.2018.05.014

Hu, X., Garzanti, E., Wang, J., Huang, W., An, W., Webb, A., 2016. The timing of India-Asia collision onset--Facts, theories, controversies. Earth-Sci. Rev. 160, 264-299.

Huang, B., He, Z., Zong, K., Zhang, Z., 2014. Zircon U-Pb and Hf isotopic study of Neoproterozoic granitic gneisses from the Alatage area, Xinjiang: constraints on the Precambrian crustal evolution in the Central Tianshan Block. Chin. Sci. Bull. 59, 100-112. https://doi.org/10.1007/s11434-013-0010-y

Huang, B., Xu, B., Zhang, C., Li, Y., Zhu, R., 2005. Paleomagnetism of the Baiyisi volcanic rocks (ca. $740 \mathrm{Ma}$ ) of Tarim, Northwest China: A continental fragment of Neoproterozoic Western Australia? Precambrian Res. 142, 83-92. https://doi.org/10.1016/j.precamres.2005.09.006

Huang, B., Yang, Z., Otofuji, Y.-I., Zhu, R., 1999. Early Paleozoic paleomagnetic poles from the western part of the North China Block and their implications. Tectonophysics 308, 377-402. https://doi.org/10.1016/S0040-1951(99)00098-0

Huang, B.C., Otofuji, Y., Yang, Z.Y., 1999. Paleomagnetic constraints on the tectonic relationship between the Alashan/Hexi Corridor Terrane and the North China Block. Geophys. Res. Lett. 26, 787-790. https://doi.org/10.1029/1999GL900097

Huang, H., Cawood, P.A., Hou, M., Xiong, F., Ni, S., 2019. Provenance of latest Mesoproterozoic to early Neoproterozoic (meta)-sedimentary rocks and implications for paleographic reconstruction 
of the Yili Block. Gondwana Res.

2361

2362

2363

2364

2365

2366

2367

2368

2369

2370

2371

2372

2373

2374

2375

2376

2377

2378

2379

2380

2381

2382

2383

2384

2385

2386

2387

2388

2389

2390

2391

2392

2393

Huang, K., Opdyke, N.D., Zhu, R., 2000. Further paleomagnetic results from the Silurian of the Yangtze Block and their implications. Earth Planet. Sci. Lett. 175, 191-202. https://doi.org/10.1016/S0012-821X(99)00302-7

Huang, Z., Long, X., Kröner, A., Yuan, C., Wang, Y., Chen, B., Zhang, Y., 2015. Neoproterozoic granitic gneisses in the Chinese Central Tianshan Block: Implications for tectonic affinity and Precambrian crustal evolution. Precambrian Res. 269, 73-89. https://doi.org/10.1016/j.precamres.2015.08.005

Iosifidi, A.G., Khramov, A.N., Rodionov, V.P., Pisarevskii, S.A., Popov, V.V., 1999. Geomagnetic reversals in the Early Paleozoic: 2. A nonsynchronous record of Middle Ordovician reversals in the Berezovskaya section, southern Siberian Platform. Izv. Phys. Solid Earth 35, 24-32.

Jackson, M., Van der Voo, R., 1985. A Lower Ordovician paleomagnetic pole from the Oneota dolomite, Upper Mississippi River Valley. J. Geophys. Res., Geol. Soc. Am. 90, 10449. https://doi.org/10.1029/JB090iB12p10449

Jacobs, J., Elburg, M., Läufer, A., Kleinhanns, I.C., Henjes-Kunst, F., Estrada, S., Ruppel, A.S., Damaske, D., Montero, P., Bea, F., 2015. Two distinct Late Mesoproterozoic/Early Neoproterozoic basement provinces in central/eastern Dronning Maud Land, East Antarctica: The missing link, $15-21^{\circ}$ E. Precambrian Res. 265, 249-272. https://doi.org/10.1016/j.precamres.2015.05.003

Jacobs, J., Opås, B., Elburg, M.A., Läufer, A., Estrada, S., Ksienzyk, A.K., Damaske, D., Hofmann, M., 2017. Cryptic sub-ice geology revealed by a U-Pb zircon study of glacial till in Dronning Maud Land, East Antarctica. Precambrian Res. 294, 1-14. https://doi.org/10.1016/j.precamres.2017.03.012

Jarrard, R.D., 2003. Subduction fluxes of water, carbon dioxide, chlorine, and potassium. Geochem. Geophys. Geosyst., Geophys. Monogr. Ser. 4. https://doi.org/10.1029/2002GC000392

Jeleńska, M., Bakhmutov, V., Konstantinienko, L., 2005. Paleomagnetic and rock magnetic data from the Silurian succession of the Dniester basin, Ukraine. Phys. Earth Planet. Inter. 149, 307-320. https://doi.org/10.1016/j.pepi.2004.10.005

Jeleńska, M., Kądziałko-Hofmokl, M., Bakhmutov, V., Poliachenko, I., Ziółkowski, P., 2015. Palaeomagnetic and rock magnetic study of Lower Devonian sediments from Podolia, SW Ukraine: remagnetization problems. Geophys. J. Int. 200, 557-573. https://doi.org/10.1093/gji/ggu411

Jian, P., Kröner, A., Jahn, B.-M., Windley, B.F., Shi, Y., Zhang, W., Zhang, F., Miao, L., Tomurhuu, D., Liu, D., 2014. Zircon dating of Neoproterozoic and Cambrian ophiolites in West Mongolia and 
implications for the timing of orogenic processes in the central part of the Central Asian Orogenic Belt. Earth-Sci. Rev. 133, 62-93. https://doi.org/10.1016/j.earscirev.2014.02.006

Jiang, G., Sohl, L.E., Christie-Blick, N., 2003. Neoproterozoic stratigraphic comparison of the Lesser Himalaya (India) and Yangtze block (south China): Paleogeographic implications. Geology 31, 917-920. https://doi.org/10.1130/G19790.1

Jing, X.-Q., Yang, Z., Tong, Y., Han, Z., 2015. A revised paleomagnetic pole from the midNeoproterozoic Liantuo Formation in the Yangtze block and its paleogeographic implications. Precambrian Res. 268, 194-211. https://doi.org/10.1016/j.precamres.2015.07.007

Johnson, P.R., Andresen, A., Collins, A.S., Fowler, A.R., Fritz, H., Ghebreab, W., Kusky, T., Stern, R.J., 2011. Late Cryogenian--Ediacaran history of the Arabian--Nubian Shield: a review of depositional, plutonic, structural, and tectonic events in the closing stages of the northern East African Orogen. J. Afr. Earth. Sci. 61, 167-232.

Johnson, R.J.E., Van Der Voo, R., 1990. Pre-folding magnetization reconfirmed for the Late OrdovicianEarly Silurian Dunn Point volcanics, Nova Scotia. Tectonophysics 178, 193-205. https://doi.org/10.1016/0040-1951(90)90146-Y

Johnson, R.J.E., Van der Voo, R., 1985. Middle Cambrian paleomagnetism of the Avalon Terrane in Cape Breton Island, Nova Scotia. Tectonics 4, 629-651. https://doi.org/10.1029/TC004i007p00629

Just, J., Schulz, B., de Wall, H., Jourdan, F., Pandit, M.K., 2011. Monazite CHIME/EPMA dating of Erinpura granitoid deformation: Implications for Neoproterozoic tectono-thermal evolution of NW India. Gondwana Res. 19, 402-412. https://doi.org/10.1016/j.gr.2010.08.002

Kamo, S.L., Gower, C.F., 1994. Note: U-Pb baddeleyite dating clarifies age of characteristic paleomagnetic remanence of Long Range dykes, southeastern Labrador.

Karlsen, K.S., Conrad, C.P., Magni, V., 2019. Deep Water Cycling and Sea Level Change Since the Breakup of Pangea. Geochem. Geophys. Geosyst. 20, 2919-2935. https://doi.org/10.1029/2019GC008232

Keppie, J.D., Davis, D.W., Krogh, T.E., 1998. U-Pb geochronological constraints on Precambrian stratified units in the Avalon Composite Terrane of Nova Scotia, Canada: tectonic implications. Can. J. Earth Sci. 35, 222-236. https://doi.org/10.1139/e97-109

Keppie, J.D., Dostal, J., 1998. Birth of the Avalon arc in Nova Scotia, Canada: geochemical evidence for 700--630 Ma back-arc rift volcanism off Gondwana. Geol. Mag. 135, 171-181.

Khramov, A.N., Iosifidi, A.G., 2009. Paleomagnetism of the Lower Ordovician and Cambrian sedimentary rocks in the section of the Narva river right bank: For the construction of the Baltic kinematic model in the Early Paleozoic. Izv. Phys. Solid Earth 45, 465-481. 
Kirschvink, J.L., Ripperdan, R.L., Evans, D.A., 1997. Evidence for a Large-Scale Reorganization of Early Cambrian Continental Masses by Inertial Interchange True Polar Wander. Science 277, 541-545. https://doi.org/10.1126/science.277.5325.541

Knesel, K.M., Cohen, B.E., Vasconcelos, P.M., Thiede, D.S., 2008. Rapid change in drift of the Australian plate records collision with Ontong Java plateau. Nature 454, 754-757. https://doi.org/10.1038/nature07138

Konstantinovskaya, E.A., 2002. The mechanism of continental crust accretion: an example of Western Kamchatka. Geotectonics/Geotektonika 36, 393-411.

Krogh, T.E., Strong, D.F., O’Brien, S.J., Papezik, V.S., 1988. Precise U-Pb zircon dates from the Avalon Terrane in Newfoundland. Can. J. Earth Sci. 25, 442-453. https://doi.org/10.1139/e88-045

Kröner, A., Alexeiev, D.V., Hegner, E., Rojas-Agramonte, Y., Corsini, M., Chao, Y., Wong, J., Windley, B.F., Liu, D., Tretyakov, A.A., 2012. Zircon and muscovite ages, geochemistry, and Nd-Hf isotopes for the Aktyuz metamorphic terrane: Evidence for an Early Ordovician collisional belt in the northern Tianshan of Kyrgyzstan. Gondwana Res. 21, 901-927. https://doi.org/10.1016/j.gr.2011.05.010

Kroner, A., Windley, B.F., Badarch, G., Tomurtogoo, O., Hegner, E., Jahn, B.M., Gruschka, S., Khain, E.V., Demoux, A., Wingate, M.T.D., 2007. Accretionary growth and crust formation in the Central Asian Orogenic Belt and comparison with the Arabian-Nubian shield. MemoirsGeological Society of America 200, 181.

Lapique, F., Bertrand, J.M., Meriem, D., 1986. A major Pan-African crustal decoupling zone in the Timgaouine area (Western Hoggar, Algeria). Journal of African Earth Sciences (1983). https://doi.org/10.1016/0899-5362(86)90028-x

Lenton, T.M., Dahl, T.W., Daines, S.J., Mills, B.J.W., Ozaki, K., Saltzman, M.R., Porada, P., 2016. Earliest land plants created modern levels of atmospheric oxygen. Proc. Natl. Acad. Sci. U. S. A. 113, 9704-9709. https://doi.org/10.1073/pnas.1604787113

Levashova, N.M., Bazhenov, M.L., Meert, J.G., Kuznetsov, N.B., Golovanova, I.V., Danukalov, K.N., Fedorova, N.M., 2013. Paleogeography of Baltica in the Ediacaran: Paleomagnetic and geochronological data from the clastic Zigan Formation, South Urals. Precambrian Res. 236, 1630. https://doi.org/10.1016/j.precamres.2013.06.006

Li, M., McNamara, A.K., 2013. The difficulty for subducted oceanic crust to accumulate at the Earth's core-mantle boundary. J. Geophys. Res. [Solid Earth] 118, 1807-1816.

Li, Yianping, McWillams, M., Sharps, R., Cox, A., Li, Yongan, Li, Q., Gao, Z., Zhang, Z., Zhai, Y., 1990. A Devonian paleomagnetic pole from red beds of the Tarim Block, China. J. Geophys. Res., Geodyn. Ser. 95, 19185. https://doi.org/10.1029/JB095iB12p19185 
Li, Z., Ding, L., Lippert, P.C., Song, P., Yue, Y., van Hinsbergen, D.J.J., 2016. Paleomagnetic constraints on the Mesozoic drift of the Lhasa terrane (Tibet) from Gondwana to Eurasia. Geology 44, $727-$ 730. https://doi.org/10.1130/G38030.1

Li, Z., Ding, L., Song, P., Fu, J., Yue, Y., 2017. Paleomagnetic constraints on the paleolatitude of the Lhasa block during the Early Cretaceous: implications for the onset of India--Asia collision and latitudinal shortening estimates across Tibet and stable Asia. Gondwana Res. 41, 352-372.

Li, Z.X., Bogdanova, S.V., Collins, A.S., Davidson, A., De Waele, B., Ernst, R.E., Fitzsimons, I.C.W., Fuck, R.A., Gladkochub, D.P., Jacobs, J., Karlstrom, K.E., Lu, S., Natapov, L.M., Pease, V., Pisarevsky, S.A., Thrane, K., Vernikovsky, V., 2008. Assembly, configuration, and break-up history of Rodinia: A synthesis. Precambrian Res. 160, 179-210. https://doi.org/10.1016/j.precamres.2007.04.021

Li, Z.-X., Evans, D.A.D., Halverson, G.P., 2013. Neoproterozoic glaciations in a revised global palaeogeography from the breakup of Rodinia to the assembly of Gondwanaland. Sediment. Geol. 294, 219-232. https://doi.org/10.1016/j.sedgeo.2013.05.016

Li, Z.X., Evans, D.A.D., Zhang, S., 2004. A $90^{\circ}$ spin on Rodinia: possible causal links between the Neoproterozoic supercontinent, superplume, true polar wander and low-latitude glaciation. Earth Planet. Sci. Lett. 220, 409-421. https://doi.org/10.1016/S0012-821X(04)00064-0

Li, Z.X., Mitchell, R.N., Spencer, C.J., Ernst, R., Pisarevsky, S., Kirscher, U., Murphy, J.B., 2019. Decoding Earth's rhythms: modulation of supercontinent cycles by longer superocean episodes. Precambrian Res. 323, 1-5.

Li, Z.-X., Zhang, L., Powell, C.M., 1995. South China in Rodinia: Part of the missing link between Australia-East Antarctica and Laurentia? Geology 23, 407-410. 2.3.CO;2">https://doi.org/10.1130/0091-7613(1995)023<0407:SCIRPO >2.3.CO;2

Li, Z.-X., Zhong, S., 2009. Supercontinent-superplume coupling, true polar wander and plume mobility: Plate dominance in whole-mantle tectonics. Phys. Earth Planet. Inter. 176, 143-156. https://doi.org/10.1016/j.pepi.2009.05.004

Liégeois, J.P., Black, R., Navez, J., Latouche, L., 1994. Early and late Pan-African orogenies in the Aïr assembly of terranes (Tuareg shield, Niger). Precambrian Res. 67, 59-88. https://doi.org/10.1016/0301-9268(94)90005-1

Liégeois, J.P., Latouche, L., Boughrara, M., Navez, J., Guiraud, M., 2003. The LATEA metacraton (Central Hoggar, Tuareg shield, Algeria): behaviour of an old passive margin during the PanAfrican orogeny. J. Afr. Earth. Sci. 37, 161-190. https://doi.org/10.1016/j.jafrearsci.2003.05.004

Liu, L., Gurnis, M., Seton, M., Saleeby, J., Müller, R.D., Jackson, J.M., 2010. The role of oceanic plateau subduction in the Laramide orogeny. Nat. Geosci. 3, 353-357. https://doi.org/10.1038/ngeo829 
Liu, L., Spasojevic, S., Gurnis, M., 2008. Reconstructing Farallon plate subduction beneath North America back to the Late Cretaceous. Science 322, 934-938. https://doi.org/10.1126/science.1162921

Liu, X., Zhao, Y., Chen, H., Song, B., 2017. New zircon U-Pb and Hf-Nd isotopic constraints on the timing of magmatism, sedimentation and metamorphism in the northern Prince Charles Mountains, East Antarctica. Precambrian Res. 299, 15-33. https://doi.org/10.1016/j.precamres.2017.07.012

Lixin, B., Rixiang, Z., Harming, W., Bin, G., Jianjun, L., 1998. New Cambrian paleomagnetic pole for Yangtze Block. Sci. China Ser. D Earth Sci. 41, 66-71. https://doi.org/10.1007/BF02984514

Llanos, M.P.I., Tait, J.A., Popov, V., Abalmassova, A., 2005. Palaeomagnetic data from Ediacaran (Vendian) sediments of the Arkhangelsk region, NW Russia: An alternative apparent polar wander path of Baltica for the Late Proterozoic-Early Palaeozoic. Earth Planet. Sci. Lett. 240, 732-747. https://doi.org/10.1016/j.eps1.2005.09.063

Loucks, V., Elmore, D.R., 1986. Absolute dating of dedolomitization and the origin of magnetization in the Cambrian Morgan Creek Limestone, central Texas. GSA Bulletin 97, 486-496. 2.0.CO;2">https://doi.org/10.1130/0016-7606(1986)97<486:ADODAT>2.0.CO;2

Lubnina, N.V., Iosifidi, A.G., Khramov, A.N., Popov, V.V., Lewandowski, M., 2007. Paleomagnetism of the Silurian and Devoni-an sedimentary formations of Podolia, Ukraine, in: Khramov, A.N. (Ed.), Paleomagnetism of the Northern Eurasia Sedimentary Basins (IN RUSSIAN). pp. 105-125.

Lubnina, N.V., Pisarevsky, S.A., Puchkov, V.N., Kozlov, V.I., Sergeeva, N.D., 2014. New paleomagnetic data from Late Neoproterozoic sedimentary successions in Southern Urals, Russia: implications for the Late Neoproterozoic paleogeography of the Iapetan realm. Int. J. Earth Sci. 103, 13171334. https://doi.org/10.1007/s00531-014-1013-X

Macdonald, F.A., Prave, A.R., Petterson, R., Smith, E.F., Pruss, S.B., Oates, K., Waechter, F., Trotzuk, D., Fallick, A.E., 2013. The Laurentian record of Neoproterozoic glaciation, tectonism, and eukaryotic evolution in Death Valley, California. GSA Bulletin 125, 1203-1223. https://doi.org/10.1130/B30789.1

Martin, M.W., Grazhdankin, D.V., Bowring, S.A., Evans, D.A., Fedonkin, M.A., Kirschvink, J.L., 2000. Age of Neoproterozoic bilatarian body and trace fossils, White Sea, Russia: implications for metazoan evolution. Science 288, 841-845. https://doi.org/10.1126/science.288.5467.841

Matthews, K.J., Maloney, K.T., Zahirovic, S., Williams, S.E., Seton, M., Müller, R.D., 2016. Global plate boundary evolution and kinematics since the late Paleozoic. Glob. Planet. Change 146, 226-250. https://doi.org/10.1016/j.gloplacha.2016.10.002

Matthews, K.J., Williams, S.E., Whittaker, J.M., Müller, R.D., Seton, M., Clarke, G.L., 2015. Geologic 
and kinematic constraints on Late Cretaceous to mid Eocene plate boundaries in the southwest Pacific. Earth-Sci. Rev. 140, 72-107. https://doi.org/10.1016/j.earscirev.2014.10.008

McCabe, C., Channell, J.E.T., 1990. Paleomagnetic results from volcanic rocks of the Shelve Inlier, Wales: evidence for a wide Late Ordovician Iapetus Ocean in Britain. Earth Planet. Sci. Lett. 96, 458-468. https://doi.org/10.1016/0012-821X(90)90020-X

McCabe, C., Channell, J.E.T., Woodcock, N.H., 1992. Further paleomagnetic results from the Builth Wells Ordovician inlier, Wales. J. Geophys. Res. [Solid Earth] 97, 9357-9370.

McCabe, C., Van der Voo, R., Wilkinson, B.H., Devaney, K., 1985. A Middle/Late Silurian paleomagnetic pole from limestone reefs of the Wabash Formation, Indiana, USA. J. Geophys. Res. [Solid Earth] 90, 2959-2965.

McCausland, P.J.A., Hodych, J.P., 1998. Paleomagnetism of the 550 Ma Skinner Cove volcanics of western Newfoundland and the opening of the Iapetus Ocean. Earth Planet. Sci. Lett. 163, 15-29. https://doi.org/10.1016/S0012-821X(98)00171-X

McCausland, P.J.A., Van der Voo, R., Hall, C.M., 2007. Circum-Iapetus paleogeography of the Precambrian-Cambrian transition with a new paleomagnetic constraint from Laurentia. Precambrian Res. 156, 125-152. https://doi.org/10.1016/j.precamres.2007.03.004

McElhinny, M.W., Cowley, J.A., Edwards, D.J., 1978. Palaeomagnetism of some rocks from Peninsular India and Kashmir. Tectonophysics 50, 41-54. https://doi.org/10.1016/0040-1951(78)90198-1

McGee, B., Halverson, G.P., Collins, A.S., 2012. Cryogenian rift-related magmatism and sedimentation: South-western Congo Craton, Namibia. J. Afr. Earth. Sci. 76, 34-49. https://doi.org/10.1016/j.jafrearsci.2012.09.003

McKenzie, D.P., Parker, R.L., 1967. The North Pacific: an Example of Tectonics on a Sphere. Nature 216, 1276-1280. https://doi.org/10.1038/2161276a0

McKenzie, R.N., Hughes, N.C., Gill, B.C., Myrow, P.M., 2014. Plate tectonic influences on Neoproterozoic-early Paleozoic climate and animal evolution. Geology 42, 127-130. https://doi.org/10.1130/G34962.1

McKerrow, W.S., Mac Niocaill, C., Ahlberg, P.E., Clayton, G., Cleal, C.J., Eagar, R.M.C., 2000. The Late Palaeozoic relations between Gondwana and Laurussia. Geological Society, London, Special Publications 179, 9-20. https://doi.org/10.1144/GSL.SP.2000.179.01.03

McMenamin, M.A., McMenamin, M.A., McMenamin, D.L.S., 1990. The emergence of animals: the Cambrian breakthrough. Columbia University Press.

Meert, J.G., 2014. Ediacaran-Early Ordovician paleomagnetism of Baltica: A review. Gondwana Res. 25, 159-169. https://doi.org/10.1016/j.gr.2013.02.003

Meert, J.G., 2003. A synopsis of events related to the assembly of eastern Gondwana. Tectonophysics 
362, 1-40. https://doi.org/10.1016/S0040-1951(02)00629-7

2565

2566

2567

2568

2569

2570

2571

2572

2573

2574

2575

2576

2577

2578

2579

2580

2581

2582

2583

2584

2585

2586

2587

2588

2589

2590

2591

2592

2593

2594

2595

2596

2597

Meert, J.G., 2002. Paleomagnetic Evidence for a Paleo-Mesoproterozoic Supercontinent Columbia. Gondwana Res. 5, 207-215. https://doi.org/10.1016/S1342-937X(05)70904-7

Meert, J.G., Lieberman, B.S., 2008. The Neoproterozoic assembly of Gondwana and its relationship to the Ediacaran-Cambrian radiation. Gondwana Res. 14, 5-21. https://doi.org/10.1016/j.gr.2007.06.007

Meert, J.G., Pandit, M.K., Kamenov, G.D., 2013. Further geochronological and paleomagnetic constraints on Malani (and pre-Malani) magmatism in NW India. Tectonophysics 608, 1254-1267. https://doi.org/10.1016/j.tecto.2013.06.019

Meert, J.G., Pandit, M.K., Pradhan, V.R., Banks, J., Sirianni, R., Stroud, M., Newstead, B., Gifford, J., 2010. Precambrian crustal evolution of Peninsular India: A 3.0 billion year odyssey. J. Asian Earth Sci. 39, 483-515. https://doi.org/10.1016/j.jseaes.2010.04.026

Meert, J.G., van der Voo, R., Ayub, S., 1995. Paleomagnetic investigation of the Neoproterozoic Gagwe lavas and Mbozi complex, Tanzania and the assembly of Gondwana. Precambrian Res. 74, $225-$ 244. https://doi.org/10.1016/0301-9268(95)00012-T

Meffre, S., Direen, N.G., Crawford, A.J., Kamenetsky, V., 2004. Mafic volcanic rocks on King Island, Tasmania: evidence for 579 Ma break-up in east Gondwana. Precambrian Res. 135, 177-191.

Merdith, A.S., Atkins, S.E., Tetley, M.G., 2019a. Tectonic Controls on Carbon and Serpentinite Storage in Subducted Upper Oceanic Lithosphere for the Past 320 Ma. Front Earth Sci. Chin. 7, 332. https://doi.org/10.3389/feart.2019.00332

Merdith, A.S., Collins, A.S., Williams, S.E., Pisarevsky, S., Foden, J.D., Archibald, D.B., Blades, M.L., Alessio, B.L., Armistead, S., Plavsa, D., Clark, C., Müller, R.D., 2017a. A full-plate global reconstruction of the Neoproterozoic. Gondwana Res. 50, 84-134. https://doi.org/10.1016/j.gr.2017.04.001

Merdith, A.S., Williams, S.E., Brune, S., Collins, A.S., Müller, R.D., 2019b. Rift and plate boundary evolution across two supercontinent cycles. Glob. Planet. Change 173, 1-14. https://doi.org/10.1016/j.gloplacha.2018.11.006

Merdith, A.S., Williams, S.E., Müller, R.D., Collins, A.S., 2017b. Kinematic constraints on the Rodinia to Gondwana transition. Precambrian Res. 299, 132-150. https://doi.org/10.1016/j.precamres.2017.07.013

Metcalfe, I., 2013. Gondwana dispersion and Asian accretion: Tectonic and palaeogeographic evolution of eastern Tethys. J. Asian Earth Sci. 66, 1-33. https://doi.org/10.1016/j.jseaes.2012.12.020

Metcalfe, I., 2011. Palaeozoic-Mesozoic history of SE Asia. Geological Society, London, Special Publications 355, 7-35. https://doi.org/10.1144/SP355.2 
Metelkin, D.V., Vernikovsky, V.A., Kazansky, A.Y., 2012. Tectonic evolution of the Siberian paleocontinent from the Neoproterozoic to the Late Mesozoic: paleomagnetic record and reconstructions. Russ. Geol. Geophys. 53, 675-688. https://doi.org/10.1016/j.rgg.2012.05.006

Miller, J.D., Kent, D.V., 1988. Paleomagnetism of the Silurian-Devonian Andreas redbeds: Evidence for an Early Devonian supercontinent? Geology 16, 195-198. 2.3.CO;2">https://doi.org/10.1130/0091-7613(1988)016<0195:POTSDA>2.3.CO;2

Mills, B., Watson, A.J., Goldblatt, C., Boyle, R., Lenton, T.M., 2011. Timing of Neoproterozoic glaciations linked to transport-limited global weathering. Nat. Geosci. 4, 861-864. https://doi.org/10.1038/ngeo1305

Mills, B.J.W., Krause, A.J., Scotese, C.R., Hill, D.J., Shields, G.A., Lenton, T.M., 2019. Modelling the long-term carbon cycle, atmospheric $\mathrm{CO} 2$, and Earth surface temperature from late Neoproterozoic to present day. Gondwana Res. 67, 172-186. https://doi.org/10.1016/j.gr.2018.12.001

Millward, D., Evans, J.A., 2003. U-Pb chronology and duration of late Ordovician magmatism in the English Lake District. J. Geol. Soc. London 160, 773-781. https://doi.org/10.1144/0016-764902160

Minh, P., Hieu, P.T., Thuy, N.T.B., Dung, L.T., Kawaguchi, K., Dung, P.T., 2020. Neoproterozoic granitoids from the Phan Si Pan Zone, NW Vietnam: geochemistry and geochronology constraints on reconstructing South China--India Palaeogeography. Int. Geol. Rev. 1-16.

Minibaev, R.A. and Sulutdinov, R.M., 1991. Paleomagnitniye kharakteristiki siluriyskikh obrazovanii sakmarskoy zoni Yuzhnogo Urala. Bashkirian Natl.Cttee.Ural.Branch Acad.Sci.USSR (Ufa) 30.

Mitchell, R.N., Kilian, T.M., Evans, D.A.D., 2012. Supercontinent cycles and the calculation of absolute palaeolongitude in deep time. Nature 482, 208-211. https://doi.org/10.1038/nature10800

Moores, E.M., 2002. Pre-1 Ga (pre-Rodinian) ophiolites: Their tectonic and environmental implications. GSA Bulletin 114, 80-95. 2.0.CO;2">https://doi.org/10.1130/00167606(2002)114<0080:PGPROT>2.0.CO;2

Moores, E.M., 1991. Southwest U.S.-East Antarctic (SWEAT) connection: A hypothesis. Geology 19, 425-428. 2.3.CO;2">https://doi.org/10.1130/0091-7613(1991)019<0425:SUSEAS>2.3.CO;2

Morgan, W.J., 1968. Rises, trenches, great faults, and crustal blocks. J. Geophys. Res. 73, 1959-1982. https://doi.org/10.1029/JB073i006p01959

Morrison, J., Ellwood, B.B., 1986. Paleomagnetism of Silurian-Ordovician sediments from the Valley and Ridge province, northwest Georgia. Geophys. Res. Lett. 13, 189-192.

Mulder, J.A., Berry, R.F., Halpin, J.A., Meffre, S., Everard, J.L., 2018a. Depositional age and correlation of the Oonah Formation: refining the timing of Neoproterozoic basin formation in Tasmania. 
Aust. J. Earth Sci. 65, 391-407. https://doi.org/10.1080/08120099.2018.1426629

Mulder, J.A., Everard, J.L., Cumming, G., Meffre, S., Bottrill, R.S., Merdith, A.S., Halpin, J.A., McNeill, A.W., Cawood, P.A., 2020. Neoproterozoic opening of the Pacific Ocean recorded by multi-stage

Mulder, J.A., Halpin, J.A., Daczko, N.R., 2015. Mesoproterozoic Tasmania: Witness to the East rifting in Tasmania, Australia. Earth-Sci. Rev. 201, 103041. https://doi.org/10.1016/j.earscirev.2019.103041 Antarctica-Laurentia connection within Nuna. Geology 43, 759-762. https://doi.org/10.1130/G36850.1

Mulder, J.A., Halpin, J.A., Daczko, N.R., Orth, K., Meffre, S., Thompson, J.M., Morrissey, L.J., 2019. A Multiproxy provenance approach to uncovering the assembly of East Gondwana in Antarctica. Geology 47, 645-649. https://doi.org/10.1130/G45952.1

Mulder, J.A., Karlstrom, K.E., Halpin, J.A., Merdith, A.S., Spencer, C.J., Berry, R.F., McDonald, B., 2018b. Rodinian devil in disguise: Correlation of 1.25-1.10 Ga strata between Tasmania and Grand Canyon. Geology 46, 991-994. https://doi.org/10.1130/G45225.1

Müller, R.D., Cannon, J., Qin, X., Watson, R.J., Gurnis, M., Williams, S., Pfaffelmoser, T., Seton, M., Russell, S.H.J., Zahirovic, S., 2018. GPlates: Building a Virtual Earth Through Deep Time. Geochem. Geophys. Geosyst. 19, 2243-2261. https://doi.org/10.1029/2018GC007584

Müller, R.D., Royer, J.-Y., Lawver, L.A., 1993. Revised plate motions relative to the hotspots from combined Atlantic and Indian Ocean hotspot tracks. Geology 21, 275-278. 2.3.CO;2">https://doi.org/10.1130/0091-7613(1993)021<0275:RPMRTT>2.3.CO;2

Müller, R.D., Sdrolias, M., Gaina, C., Steinberger, B., Heine, C., 2008. Long-term sea-level fluctuations driven by ocean basin dynamics. Science $319,1357-1362$. https://doi.org/10.1126/science.1151540

Müller, R.D., Seton, M., Zahirovic, S., Williams, S.E., Matthews, K.J., Wright, N.M., Shephard, G.E., Maloney, K.T., Barnett-Moore, N., Hosseinpour, M., Bower, D.J., Cannon, J., 2016. Ocean Basin Evolution and Global-Scale Plate Reorganization Events Since Pangea Breakup. Annu. Rev. Earth Planet. Sci. 44, 107-138. https://doi.org/10.1146/annurev-earth-060115-012211

Müller, R.D., Zahirovic, S., Williams, S.E., Cannon, J., Seton, M., Bower, D.J., Tetley, M., Heine, C., Le Breton, E., Liu, S., Russell, S.H.J., Yang, T., Leonard, J., Gurnis, M., 2019. A global plate model including lithospheric deformation along major rifts and orogens since the Triassic. Tectonics. https://doi.org/10.1029/2018TC005462

Murphy, J.B., 2002. Geochemistry of the Neoproterozoic metasedimentary Gamble Brook Formation, Avalon terrane, Nova Scotia: evidence for a rifted-arc environment along the west Gondwanan margin of Rodinia. J. Geol. 110, 407-419. 
Murphy, J.B., Keppie, J.D., Dostal, J., Nance, R.D., 1999. Neoproterozoic-early Paleozoic evolution ofAvalonia. Laurentia-Gondwana Connections Before Pangea 336, 253.

Murphy, J.B., Nance, R.D., 1989. Model for the evolution of the Avalonian-Cadomian belt. Geology 17, 735-738. 2.3.CO;2">https://doi.org/10.1130/0091-7613(1989)017<0735:MFTEOT>2.3.CO;2

Murphy, J.B., Pisarevsky, S.A., Nance, R.D., Keppie, J.D., 2004. Neoproterozoic—Early Paleozoic evolution of peri-Gondwanan terranes: implications for Laurentia-Gondwana connections. Int. J. Earth Sci. 93, 659-682. https://doi.org/10.1007/s00531-004-0412-9

Murphy, J.B., Strachan, R.A., Nance, R.D., Parker, K.D., Fowler, M.B., 2000. Proto-Avalonia: A 1.2-1.0 Ga tectonothermal event and constraints for the evolution of Rodinia. Geology 28, 1071-1074. 2.0.CO;2">https://doi.org/10.1130/0091-7613(2000)28<1071:PAGTEA>2.0.CO;2

Murphy, J.B., Waldron, J.W.F., Kontak, D.J., Pe-Piper, G., Piper, D.J.W., 2011. Minas Fault Zone: Late Paleozoic history of an intra-continental orogenic transform fault in the Canadian Appalachians. J. Struct. Geol. 33, 312-328. https://doi.org/10.1016/j.jsg.2010.11.012

Murthy, G., Gower, C., Tubrett, M., Pätzold, R., 1992. Paleomagnetism of Eocambrian Long Range dykes and Double Mer Formation from Labrador, Canada. Can. J. Earth Sci. 29, 1224-1234. https://doi.org/10.1139/e92-098

Nance, R.D., Linnemann, U., 2008. The Rheic Ocean: origin, evolution, and significance. GSA Today 18, 4-12.

Nance, R.D., Murphy, J.B., Strachan, R.A., Keppie, J.D., Gutiérrez-Alonso, G., Fernández-Suárez, J., Quesada, C., Linnemann, U., D’lemos, R., Pisarevsky, S.A., 2008. Neoproterozoic-early Palaeozoic tectonostratigraphy and palaeogeography of the peri-Gondwanan terranes: Amazonian v. West African connections. Geological Society, London, Special Publications 297, 345-383.

Nick, K.E., Elmore, R.D., 1990. Paleomagnetism of the Cambrian Royer Dolomite and Pennsylvanian Collings Ranch Conglomerate, southern Oklahoma: An early Paleozoic magnetization and nonpervasive remagnetization by weathering. Geol. Soc. Am. Bull. 102, 1517-1525.

Niu, J., Li, Z.-X., Zhu, W., 2016. Palaeomagnetism and geochronology of mid-Neoproterozoic Yanbian dykes, South China: implications for a c. 820-800 Ma true polar wander event and the reconstruction of Rodinia. Geological Society, London, Special Publications 424, 191-121. https://doi.org/http: //doi.org/10.1144/SP424.11

Noel, J.R., Spariosu, D.J., Dallmeyer, R.D., 1988. Paleomagnetism and 40Ar/39Ar ages from the Carolina slate belt, Albemarle, North Carolina: Implications for terrane amalgamation with North America. Geology 16, 64-68.

O’Brien, S.J., Dunning, G.R., Dube, B., O’Driscoll, C.F., Sparkes, B., Israel, S., Ketchum, J., 2001. New insights into the Neoproterozoic geology of the central Avalon Peninsula (parts of NTS map areas 
$1 \mathrm{~N} / 6,1 \mathrm{~N} / 7$ and 1N/3), eastern Newfoundland. Current Research, Government of Newfoundland and Labrador, Department of Mines and Energy, Geological Survey 2001, 169-189.

O’Neill, C., Müller, D., Steinberger, B., 2005. On the uncertainties in hot spot reconstructions and the significance of moving hot spot reference frames. Geochem. Geophys. Geosyst., Spec. Pap. Geol. Soc. Am. 6. https://doi.org/10.1029/2004GC000784

Opdyke, N.D., Huang, K., Xu, G., Zhang, W.Y., Kent, D.V., 1987. Paleomagnetic results from the Silurian of the Yangtze paraplatform. Tectonophysics 139, 123-132. https://doi.org/10.1016/0040-1951(87)90201-0

Palin, R.M., Santosh, M., Cao, W., Li, S.S., 2020. Secular change and the onset of plate tectonics on Earth. Earth-Sci. Rev.

Pan, B., Brock, G.A., Skovsted, C.B., Betts, M.J., Topper, T.P., Li, G., 2018. Paterimitra pyramidalis Laurie, 1986, the first tommotiid discovered from the early Cambrian of North China. Gondwana Res. 63, 179-185. https://doi.org/10.1016/j.gr.2018.05.014

Pandit, M.K., Carter, L.M., Ashwal, L.D., Tucker, R.D., Torsvik, T.H., Jamtveit, B., Bhushan, S.K., 2003. Age, petrogenesis and significance of $1 \mathrm{Ga}$ granitoids and related rocks from the Sendra area, Aravalli Craton, NW India. J. Asian Earth Sci. 22, 363-381.

Paquette, J.L., Caby, R., Djouadi, M.T., Bouchez, J.L., 1998. U-Pb dating of the end of the Pan-African orogeny in the Tuareg shield: the post-collisional syn-shear Tioueine pluton (Western Hoggar, Algeria). Lithos 45, 245-253. https://doi.org/10.1016/S0024-4937(98)00034-6

Parsons, A.J., Hosseini, K., Palin, R.M., Sigloch, K., 2020. Geological, geophysical and plate kinematic constraints for models of the India-Asia collision and the post-Triassic central Tethys oceans. Earth-Sci. Rev. 208, 103084. https://doi.org/10.1016/j.earscirev.2020.103084

Pavlov, V., Bachtadse, V., Mikhailov, V., 2008. New Middle Cambrian and Middle Ordovician palaeomagnetic data from Siberia: Llandelian magnetostratigraphy and relative rotation between the Aldan and Anabar--Angara blocks. Earth Planet. Sci. Lett. 276, 229-242.

Pavlov, V., Gallet, Y., 1998. Upper Cambrian to Middle Ordovician magnetostratigraphy from the Kulumbe river section (northwestern Siberia). Phys. Earth Planet. Inter. 108, 49-59. https://doi.org/10.1016/S0031-9201(98)00087-9

Pavlov, V.E., Shatsillo, A.V., Petrov, P.Y., 2015. Paleomagnetism of the upper Riphean deposits in the Turukhansk and Olenek uplifts and Uda Pre-Sayan region and the neoproterozoic drift of the Siberian Platform. Izv. Phys. Solid Earth 51, 716-747. https://doi.org/10.1134/S1069351315050092

Pavlov, V.E., Veselovskiy, R.V., Shatsillo, A.V., Gallet, Y., 2012. Magnetostratigraphy of the Ordovician Angara/Rozhkova River section: Further evidence for the Moyero reversed superchron. Izv. Phys. 
Pedrosa-Soares, A.C., Noce, C.M., Wiedemann, C.M., Pinto, C.P., 2001. The Aracua1-West-Congo Orogen in Brazil: an overview of a confined orogen formed during Gondwanaland assembly. Precambrian Res. 110, 307-323.

Pehrsson, S.J., Berman, R.G., Eglington, B., Rainbird, R., 2013. Two Neoarchean supercontinents revisited: The case for a Rae family of cratons. Precambrian Res. 232, 27-43. https://doi.org/10.1016/j.precamres.2013.02.005

Peng, Y., Yu, S., Li, S., Zhang, J., Liu, Y., Li, Y., Santosh, M., 2019. Early Neoproterozoic magmatic imprints in the Altun-Qilian-Kunlun region of the Qinghai-Tibet Plateau: Response to the assembly and breakup of Rodinia supercontinent. Earth-Sci. Rev. 199, 102954. https://doi.org/10.1016/j.earscirev.2019.102954

Pisarevsky, S., Bylund, G., 1998. Neoproterozoic palaeomagnetic directions in rocks from a key section of the Protogine Zone, southern Sweden. Geophys. J. Int. 133, 185-200. https://doi.org/10.1046/j.1365-246X.1998.1331497.x

Pisarevsky, S.A., Elming, S.-Å., Pesonen, L.J., Li, Z.-X., 2014. Mesoproterozoic paleogeography: Supercontinent and beyond. Precambrian Res. 244, 207-225. https://doi.org/10.1016/j.precamres.2013.05.014

Pisarevsky, S.A., Gladkochub, D.P., Konstantinov, K.M., Mazukabzov, A.M., Stanevich, A.M., Murphy, J.B., Tait, J.A., Donskaya, T.V., Konstantinov, I.K., 2013. Paleomagnetism of Cryogenian Kitoi mafic dykes in South Siberia: Implications for Neoproterozoic paleogeography. Precambrian Res. 231, 372-382. https://doi.org/10.1016/j.precamres.2013.04.007

Pisarevsky, S.A., Gurevich, E.L., Khramov, A.N., 1997. Palaeomagnetism of Lower Cambrian sediments from the Olenek River section (northern Siberia): palaeopoles and the problem of magnetic polarity in the Early Cambrian. Geophys. J. Int. 130, 746-756. https://doi.org/10.1111/j.1365246X.1997.tb01869.x

Pisarevsky, S.A., Murphy, J.B., Cawood, P.A., Collins, A.S., 2008. Late Neoproterozoic and Early Cambrian palaeogeography: models and problems. Geological Society, London, Special Publications 294, 9-31. https://doi.org/10.1144/SP294.2

Pisarevsky, S.A., Natapov, L.M., 2003. Siberia and Rodinia. Tectonophysics 375, 221-245. https://doi.org/10.1016/j.tecto.2003.06.001

Pisarevsky, S.A., Wingate, M.T.D., Stevens, M.K., Haines, P.W., 2007. Palaeomagnetic results from the Lancer 1 stratigraphic drillhole, Officer Basin, Western Australia, and implications for Rodinia reconstructions. Aust. J. Earth Sci. 54, 561-572. https://doi.org/10.1080/08120090701188962

Plavsa, D., Collins, A.S., Foden, J.D., Clark, C., 2015. The evolution of a Gondwanan collisional orogen: 
A structural and geochronological appraisal from the Southern Granulite Terrane, South India. Tectonics 34, 820-857.

Popov, V., Iosifidi, A., Khramov, A., Tait, J., Bachtadse, V., 2002. Paleomagnetism of Upper Vendian sediments from the Winter Coast, White Sea region, Russia: implications for the paleogeography of Baltica during Neoproterozoic times. J. Geophys. Res. [Solid Earth] 107, EPM-10.

Popov, V.V., Khramov, A.N., Bachtadse, V., 2005. Palaeomagnetism, magnetic stratigraphy, and petromagnetism of the Upper Vendian sedimentary rocks in the sections of the Zolotitsa River and in the Verkhotina Hole, Winter Coast of the White Sea, Russia. Russian Journal of Earth Sciences 7.

Powell, C.M., Pisarevsky, S.A., 2002. Late Neoproterozoic assembly of East Gondwana. Geology 30, 3 6. 2.0.CO;2">https://doi.org/10.1130/0091-7613(2002)030<0003:LNAOEG>2.0.CO;2

Powerman, V., Shatsillo, A., Coe, R., Zhao, X., Gladkochub, D., Buchwaldt, R., Pavlov, V., 2013. Palaeogeography of the Siberian platform during middle Palaeozoic Times ( 450--400 Ma): new palaeomagnetic evidence from the Lena and Nyuya rivers. Geophys. J. Int. 194, 1412-1440.

Qiantao, B., Shanlin, G., Dihui, L., Zhengren, Y., Chengfa, C., Xiaoquan, L., 2001. A study of the Kunlun-Qilian-Qinling suture system. Acta Geologica Sinica-English Edition 75, 364-374.

Rapalini, A.E., 2006. New late Proterozoic paleomagnetic pole for the Rio de la Plata craton: Implications for Gondwana. Precambrian Res. 147, 223-233. https://doi.org/10.1016/j.precamres.2006.01.016

Rapalini, A.E., Cingolani, C.A., 2004. First Late Ordovician Paleomagnetic Pole for the Cuyania (Precordillera) Terrane of Western Argentina: a Microcontinent or a Laurentian Plateau. Gondwana Res. 7, 1089-1104. https://doi.org/10.1016/S1342-937X(05)71086-8

Rapalini, A.E., Tohver, E., Bettucci, L.S., Lossada, A.C., Barcelona, H., Pérez, C., 2015. The late Neoproterozoic Sierra de las Ánimas Magmatic Complex and Playa Hermosa Formation, southern Uruguay, revisited: Paleogeographic implications of new paleomagnetic and precise geochronologic data. Precambrian Res. 259, 143-155. https://doi.org/10.1016/j.precamres.2014.11.021

Raub, T.D., Kirschvink, J.L., Evans, D.A.D., 2007. True polar wander: Linking deep and shallow geodynamics to hydro-and biospheric hypotheses. Treatise on geophysics 5, 565-589.

Raza, M., Khan, A., Bhardwaj, V.R., Rais, S., 2012. Geochemistry of Mesoproterozoic sedimentary rocks of upper Vindhyan Group, southeastern Rajasthan and implications for weathering history, composition and tectonic setting of continental crust in the northern part of Indian shield. J. Asian Earth Sci. 48, 160-172.

Robert, B., Besse, J., Blein, O., Greff-Lefftz, M., Baudin, T., Lopes, F., Meslouh, S., Belbadaoui, M., 2017. Constraints on the Ediacaran inertial interchange true polar wander hypothesis: A new 
paleomagnetic study in Morocco (West African Craton). Precambrian Res. 295, 90-116. https://doi.org/10.1016/j.precamres.2017.04.010

Robert, B., Domeier, M., Jakob, J., 2020. Iapetan Oceans: An analog of Tethys? Geology.

Rodionov, V.P., 1966. Dipole character of the Geomagnetic field in the Late Cambrian and the Ordovician in the south of the Siberian Platform. Geol. Geofiz. 1, 94-101.

Rodionov, V.P., Dekkers, M.J., Khramov, A.N., Gurevich, E.L., Krijgsman, W., Duermeijer, C.E., Heslop, D., 2003. Paleomagnetism and cyclostratigraphy of the Middle Ordovician Krivolutsky suite, Krivaya Luka section, southern Siberian platform: record of non-synchronous NRMcomponents or a non-axial geomagnetic field? Studia Geophys. Geodaetica 47, 255-274.

Rodionov, V.P., Khramov, A.N., Pisarevskii, S.A., Popov, V.V., Iosifidi, A.G., 1998. Geomagnetic Reversals in the Early Paleozoic. 1. A Late Cambrian Reversal Recorded in the Ichera Section, Southern Siberian Platform. Izv. Phys. Solid Earth 34, 1009-1017.

Rogers, J.J.W., Santosh, M., 2002. Configuration of Columbia, a Mesoproterozoic Supercontinent. Gondwana Res. 5, 5-22. https://doi.org/10.1016/S1342-937X(05)70883-2

Ross, M.I., Scotese, C.R., 1988. A hierarchical tectonic model of the Gulf of Mexico and Caribbean region. Tectonophysics.

Ruppel, A., Jacobs, J., Eagles, G., Läufer, A., Jokat, W., 2018. New geophysical data from a key region in East Antarctica: Estimates for the spatial extent of the Tonian Oceanic Arc Super Terrane (TOAST). Gondwana Res. 59, 97-107. https://doi.org/10.1016/j.gr.2018.02.019

Safonova, I., Biske, G., Romer, R.L., Seltmann, R., Simonov, V., Maruyama, S., 2016. Middle Paleozoic mafic magmatism and ocean plate stratigraphy of the South Tianshan, Kyrgyzstan. Gondwana Res. 30, 236-256. https://doi.org/10.1016/j.gr.2015.03.006

Schellart, W.P., Lister, G.S., Toy, V.G., 2006. A Late Cretaceous and Cenozoic reconstruction of the Southwest Pacific region: Tectonics controlled by subduction and slab rollback processes. EarthSci. Rev. 76, 191-233. https://doi.org/10.1016/j.earscirev.2006.01.002

Scherstén, A., Årebäck, H., Cornell, D., Hoskin, P., Åberg, A., Armstrong, R., 2000. Dating maficultramafic intrusions by ion-microprobing contact-melt zircon: examples from SW Sweden. Contrib. Mineral. Petrol. 139, 115-125. https://doi.org/10.1007/s004100050577

Schmidt, P.W., Williams, G.E., 2010. Ediacaran palaeomagnetism and apparent polar wander path for Australia: no large true polar wander. Geophys. J. Int. 182, 711-726. https://doi.org/10.1111/j.1365-246X.2010.04652.x

Schmidt, P.W., Williams, G.E., 1996. Palaeomagnetism of the ejecta-bearing Bunyeroo Formation, late Neoproterozoic, Adelaide fold belt, and the age of the Acraman impact. Earth Planet. Sci. Lett. 144, 347-357. https://doi.org/10.1016/S0012-821X(96)00169-0 
Schmidt, P.W., Williams, G.E., 1995. The Neoproterozoic climatic paradox: Equatorial palaeolatitude for Marinoan glaciation near sea level in South Australia. Earth Planet. Sci. Lett. 134, 107-124. https://doi.org/10.1016/0012-821X(95)00106-M

Schmidt, P.W., Williams, G.E., Embleton, B.J.J., 1991. Low palaeolatitude of Late Proterozoic glaciation: early timing of remanence in haematite of the Elatina Formation, South Australia. Earth Planet. Sci. Lett. 105, 355-367. https://doi.org/10.1016/0012-821X(91)90177-J

Schmidt, P.W., Williams, G.E., McWilliams, M.O., 2009. Palaeomagnetism and magnetic anisotropy of late Neoproterozoic strata, South Australia: Implications for the palaeolatitude of late Cryogenian glaciation, cap carbonate and the Ediacaran System. Precambrian Res. 174, 35-52. https://doi.org/10.1016/j.precamres.2009.06.002

Scotese, C.R., 2016. PALEOMAP PaleoAtlas for GPlates and the PaleoData Plotter Program, PALEOMAP Project. See http://www. earthbyte. org/paleomap-paleoatlas-for-gplates.

Scotese, C.R., 2004. A Continental Drift Flipbook. J. Geol. 112, 729-741. https://doi.org/10.1086/424867

Seton, M., Müller, R.D., Zahirovic, S., Gaina, C., Torsvik, T., Shephard, G., Talsma, A., Gurnis, M., Turner, M., Maus, S., Chandler, M., 2012. Global continental and ocean basin reconstructions since 200 Ma. Earth-Sci. Rev. 113, 212-270. https://doi.org/10.1016/j.earscirev.2012.03.002

Shapiro, M.N., Solov'ev, A.V., 2009. Formation of the Olyutorsky-Kamchatka foldbelt: a kinematic model. Russ. Geol. Geophys. 50, 668-681. https://doi.org/10.1016/j.rgg.2008.10.006

Shatsillo, A.V., Paverman, V.I., Pavlov, V.E., 2007. Middle paleozoic segment of the apparent polar wander path from the Siberian platform: New paleomagnetic evidence for the Silurian of the Nyuya-Berezovskii facial province. Izv. Phys. Solid Earth 43, 880-889. https://doi.org/10.1134/S1069351307100102

Shephard, G.E., Müller, R.D., Seton, M., 2013. The tectonic evolution of the Arctic since Pangea breakup: Integrating constraints from surface geology and geophysics with mantle structure. Earth-Sci. Rev. 124, 148-183. https://doi.org/10.1016/j.earscirev.2013.05.012

Shervais, J.W., Dennis, A.J., McGee, J.J., Secor, D., 2003. Deep in the heart of Dixie: Pre-Alleghanian eclogite and HP granulite metamorphism in the Carolina Terrane, South Carolina, USA. J. Metamorph. Geol. 21, 65-80.

Shi, R., Yang, J., Wu, C., Wooden, J., 2004. First SHRIMP dating for the formation of the late Sinian Yushigou Ophiolite, North Qilian Mountains. ACTA GEOLOGICA SINICA-CHINESE EDITION- 78, 649-657.

Shi, Y., Zhang, W., Kröner, A., Li, L., Jian, P., 2018. Cambrian ophiolite complexes in the Beishan area, China, southern margin of the Central Asian Orogenic Belt. J. Asian Earth Sci. 153, 193-205. https://doi.org/10.1016/j.jseaes.2017.05.021 
Sigloch, K., Mihalynuk, M.G., 2013. Intra-oceanic subduction shaped the assembly of Cordilleran North America. Nature 496, 50-56. https://doi.org/10.1038/nature12019

Slagstad, T., Kulakov, E., Kirkland, C.L., Roberts, N.M.W., Ganerød, M., 2019. Breaking the GrenvilleSveconorwegian link in Rodinia reconstructions. Terra Nova 31, 430-437. https://doi.org/10.1111/ter.12406

Smethurst, M.A., Khramov, A.N., 1992. A new Devonian palaeomagnetic pole for the Russian platform and Baltica, and related apparent polar wander. Geophys. J. Int. 108, 179-192. https://doi.org/10.1111/j.1365-246X.1992.tb00848.x

Smethurst, M.A., Khramov, A.N., Pisarevsky, S., 1998. Palaeomagnetism of the Lower Ordovician Orthoceras Limestone, St. Petersburg, and a revised drift history for Baltica in the early Palaeozoic. Geophys. J. Int. 133, 44-56. https://doi.org/10.1046/j.1365-246X.1998.1331463.x

Smirnov, A.V., Evans, D.A.D., Ernst, R.E., Söderlund, U., Li, Z.-X., 2013. Trading partners: Tectonic ancestry of southern Africa and western Australia, in Archean supercratons Vaalbara and Zimgarn. Precambrian Res. 224, 11-22. https://doi.org/10.1016/j.precamres.2012.09.020

Sohl, L.E., Christie-Blick, N., Kent, D.V., 1999. Paleomagnetic polarity reversals in Marinoan (ca. 600 Ma) glacial deposits of Australia: Implications for the duration of low-latitude glaciation in Neoproterozoic time. GSA Bulletin 111, 1120-1139. 2.3.CO;2">https://doi.org/10.1130/00167606(1999)111<1120:PPRIMC $>2.3 . C O ; 2$

Soldati, G., Boschi, L., Piersanti, A., Spada, G., 2001. The effect of global seismicity on the polar motion of a viscoelastic Earth. J. Geophys. Res. 106, 6761-6767. https://doi.org/10.1029/2000JB900354

Song, S., Li, X.-H., 2019. A positive test for the Greater Tarim Block at the heart of Rodinia: Megadextral suturing of supercontinent assembly: COMMENT. Geology 47, e453-e453.

Song, S., Niu, Y., Su, L., Xia, X., 2013. Tectonics of the North Qilian orogen, NW China. Gondwana Res. 23, 1378-1401. https://doi.org/10.1016/j.gr.2012.02.004

Song, S., Niu, Y., Zhang, L., Wei, C., Liou, J.G., Su, L., 2009. Tectonic evolution of early Paleozoic HP metamorphic rocks in the North Qilian Mountains, NW China: New perspectives. J. Asian Earth Sci. 35, 334-353. https://doi.org/10.1016/j.jseaes.2008.11.005

Song, S., Su, L., Li, X.-H., Niu, Y., Zhang, L., 2012. Grenville-age orogenesis in the Qaidam-Qilian block: The link between South China and Tarim. Precambrian Res. 220-221, 9-22. https://doi.org/10.1016/j.precamres.2012.07.007

Stampfli, G.M., Borel, G.D., 2002. A plate tectonic model for the Paleozoic and Mesozoic constrained by dynamic plate boundaries and restored synthetic oceanic isochrons. Earth Planet. Sci. Lett. 196, 17-33. https://doi.org/10.1016/S0012-821X(01)00588-X

Stearn, J.E.F., Piper, J.D.A., 1984. Sub-Department of Geophysics, University of Liverpool, Liverpool 
L69 3BX (Gt. Britain). Precambrian Res. 23, 201-246.

2905

2906

2907

2908

2909

2910

2911

2912

2913

2914

2915

2916

2917

2918

2919

2920

2921

2922

2923

2924

2925

2926

2927

2928

2929

2930

2931

2932

2933

2934

2935

2936

2937

Steinberger, B., Torsvik, T.H., 2008. Absolute plate motions and true polar wander in the absence of hotspot tracks. Nature 452, 620-623. https://doi.org/10.1038/nature06824

Stern, R.J., 1994. Arc Assembly and Continental Collision in the Neoproterozoic East African Orogen: Implications for the Consolidation of Gondwanaland. Annu. Rev. Earth Planet. Sci. 22, 319-351. https://doi.org/10.1146/annurev.ea.22.050194.001535

Stern, R.J., Miller, N.R., 2018. Did the transition to plate tectonics cause Neoproterozoic Snowball Earth? Terra Nova 30, 87-94. https://doi.org/10.1111/ter.12321

Strachan, R.A., Collins, A.S., Buchan, C., Nance, R.D., Murphy, J.B., D’Lemos, R.S., 2007. Terrane analysis along a Neoproterozoic active margin of Gondwana: insights from $\mathrm{U}-\mathrm{Pb}$ zircon geochronology. J. Geol. Soc. London 164, 57-60. https://doi.org/10.1144/0016-76492006-014

Sun, L.-S., Huang, B.-C., 2009. New paleomagnetic result for Ordovician rocks from the Tarim Block, Northwest China and its tectonic implications.

Surkis, Y.F., Rodionov, V.P., Khramov, A.N., Gurevich, E.L., Westfahl, M., 1999. Geomagnetic reversals in the early Paleozoic: 3. Reversals recorded in redbeds of the lower Ordovician Mandra section, Siberia. Izv. Phys. Solid Earth 35, 347-357.

Sutherland, R., Dickens, G.R., Blum, P., Agnini, C., Alegret, L., Asatryan, G., Bhattacharya, J., Bordenave, A., Chang, L., Collot, J., Cramwinckel, M.J., Dallanave, E., Drake, M.K., Etienne, S.J.G., Giorgioni, M., Gurnis, M., Harper, D.T., Huang, H.-H.M., Keller, A.L., Lam, A.R., Li, H., Matsui, H., Morgans, H.E.G., Newsam, C., Park, Y.-H., Pascher, K.M., Pekar, S.F., Penman, D.E., Saito, S., Stratford, W.R., Westerhold, T., Zhou, X., 2020. Continental-scale geographic change across Zealandia during Paleogene subduction initiation. Geology 48, 419-424. https://doi.org/10.1130/G47008.1

Swanson-Hysell, N.L., Maloof, A.C., Kirschvink, J.L., Evans, D.A.D., Halverson, G.P., Hurtgen, M.T., 2012. Constraints on Neoproterozoic paleogeography and Paleozoic orogenesis from paleomagnetic records of the Bitter Springs Formation, Amadeus Basin, central Australia. Am. J. Sci. 312, 817-884. https://doi.org/10.2475/08.2012.01

Tetley, M.G., 2018. Constraining Earth's plate tectonic evolution through data mining and knowledge discovery $(\mathrm{PhD})$. The University of Sydney.

Tetley, M.G., Williams, S.E., Gurnis, M., Flament, N., Müller, R.D., 2019. Constraining absolute plate motions since the Triassic. J. Geophys. Res. [Solid Earth]. https://doi.org/10.1029/2019JB017442 Thomas, R.J., De Waele, B., Schofield, D.I., Goodenough, K.M., Horstwood, M., Tucker, R., Bauer, W., Annells, R., Howard, K., Walsh, G., Rabarimanana, M., Rafahatelo, J.M., Ralison, A.V., Randriamananjara, T., 2009. Geological evolution of the Neoproterozoic Bemarivo Belt, northern 
Thompson, M.D., Grunow, A.M., Ramezani, J., 2010. Cambro-Ordovician paleogeography of the Southeastern New England Avalon Zone: Implications for Gondwana breakup. GSA Bulletin 122, 76-88. https://doi.org/10.1130/B26581.1

Thorogood, E.J., 1990. Provenance of the pre-Devonian sediments of England and Wales: Sm-Nd isotopic evidence. J. Geol. Soc. London 147, 591-594. https://doi.org/10.1144/gsjgs.147.4.0591

Torsvik, T.H., Ashwal, L.D., Tucker, R.D., Eide, E.A., 2001. Neoproterozoic geochronology and palaeogeography of the Seychelles microcontinent: the India link. Precambrian Res. 110, 47-59. https://doi.org/10.1016/S0301-9268(01)00180-2

Torsvik, T.H., Burke, K., Steinberger, B., Webb, S.J., Ashwal, L.D., 2010a. Diamonds sampled by plumes from the core-mantle boundary. Nature 466, 352-355. https://doi.org/10.1038/nature09216

Torsvik, T.H., Cocks, L.R.M., 2017. The integration of palaeomagnetism, the geological record and mantle tomography in the location of ancient continents. Geol. Mag. 1-19. https://doi.org/10.1017/S001675681700098X

Torsvik, T.H., Cocks, L.R.M., 2016. Earth History and Palaeogeography. Cambridge University Press.

Torsvik, T.H., Cocks, L.R.M., 2009. The Lower Palaeozoic palaeogeographical evolution of the northeastern and eastern peri-Gondwanan margin from Turkey to New Zealand. Geological Society, London, Special Publications 325, 3-21. https://doi.org/10.1144/SP325.2

Torsvik, T.H., Dietmar Muller, R., Van der Voo, R., Steinberger, B., Gaina, C., 2008. Global Plate Motion Frames: Toward a Unified Model. Reviews of Geophysics 46. https://doi.org/10.1029/2007RG000227

Torsvik, T.H., Domeier, M., 2017. Correspondence: Numerical modelling of the PERM anomaly and the Emeishan large igneous province. Nat. Commun. 8, 821. https://doi.org/10.1038/s41467-017$00125-2$

Torsvik, T.H., Rehnström, E.F., 2001. Cambrian palaeomagnetic data from Baltica: implications for true polar wander and Cambrian palaeogeography. J. Geol. Soc. London 158, 321-329. https://doi.org/10.1144/jgs.158.2.321

Torsvik, T.H., Smethurst, M.A., 1989. GMAP32 - Geographic Mapping and Reconstruction System. Geol. Surv. of Norway, Oslo 1997.

Torsvik, T.H., Smethurst, M.A., Meert, J.G., Van der Voo, R., McKerrow, W.S., Brasier, Sturt, B.A., Walderhaug, H.J., 1996. Continental break-up and collision in the Neoproterozoic and Palaeozoic - A tale of Baltica and Laurentia. Earth-Sci. Rev. 40, 229-258. https://doi.org/10.1016/00128252(96)00008-6 
Torsvik, T.H., Steinberger, B., Gurnis, M., Gaina, C., 2010b. Plate tectonics and net lithosphere rotation over the past 150My. Earth Planet. Sci. Lett. 291, 106-112. https://doi.org/10.1016/j.epsl.2009.12.055

Torsvik, T.H., Tait, J., Moralev, V.M., McKerrow, W.S., Sturt, B.A., Roberts, D., 1995. Ordovician palaeogeography of Siberia and adjacent continents. J. Geol. Soc. London 152, 279-287.

Torsvik, T.H., Trench, A., 1991. The Lower-Middle Ordovician palaeofield of Scandinavia: southern Sweden "revisited." Phys. Earth Planet. Inter. 65, 283-291.

Torsvik, T.H., Trench, A., McKerrow, W.S., 1994. Implications of palaeomagnetic data from the Tortworth Silurian inlier (southern Britain) to palaeogeography and Variscan tectonism. Geophys. J. Int. 119, 91-100.

Torsvik, T.H., Trench, A., Svensson, I., Walderhaug, H.J., 1993. Palaeogeographic significance of midSilurian palaeomagnetic results from southern Britain - major revision of the apparent polar wander path for eastern Avalonia. Geophys. J. Int. 113, 651-668.

Torsvik, T.H., Van der Voo, R., 2002. Refining Gondwana and Pangea palaeogeography: estimates of Phanerozoic non-dipole (octupole) fields. Geophys. J. Int. 151, 771-794. https://doi.org/10.1046/j.1365-246X.2002.01799.x

Torsvik, T.H., van der Voo, R., Doubrovine, P.V., Burke, K., Steinberger, B., Ashwal, L.D., Trønnes, R.G., Webb, S.J., Bull, A.L., 2014. Deep mantle structure as a reference frame for movements in and on the Earth. Proc. Natl. Acad. Sci. U. S. A. 111, 8735-8740. https://doi.org/10.1073/pnas.1318135111

Torsvik, T.H., Van der Voo, R., Preeden, U., Mac Niocaill, C., Steinberger, B., Doubrovine, P.V., van Hinsbergen, D.J.J., Domeier, M., Gaina, C., Tohver, E., Meert, J.G., McCausland, P.J.A., Cocks, L.R.M., 2012. Phanerozoic polar wander, palaeogeography and dynamics. Earth-Sci. Rev. 114, 325-368. https://doi.org/10.1016/j.earscirev.2012.06.007

Trench, A., Torsvik, T.H., 1991. A revised Palaeozoic apparent polar wander path for Southern Britain (Eastern Avalonia). Geophys. J. Int. 104, 227-233. https://doi.org/10.1111/j.1365246X.1991.tb02506.x

Trench, A., Torsvik, T.H., Dentith, M.C., Walderhaug, H., Traynor, J.-J., 1992. A high southerly palaeolatitude for Southern Britain in Early Ordovician times: palaeomagnetic data from the Treffgarne Volcanic Formation SW Wales. Geophys. J. Int. 108, 89-100.

Tretyakov, A.A., Degtyarev, K.E., Kovach, V.P., Kotov, A.B., Salnikova, E.B., Pilitsyna, A.V., Yakovleva, S.Z., 2016. The migmatite-gneiss complex of the Chuya-Kendyktas sialic massif (Southern Kazakhstan): Structure and age. Dokl. Earth Sci. 467, 236-240. https://doi.org/10.1134/S1028334X16030156 
Tucker, R.D., Ashwal, L.D., Torsvik, T.H., 2001. U-Pb geochronology of Seychelles granitoids: a Neoproterozoic continental arc fragment. Earth Planet. Sci. Lett. 187, 27-38. https://doi.org/10.1016/S0012-821X(01)00282-5

Tucker, R.D., Roig, J.Y., Macey, P.H., Delor, C., Amelin, Y., Armstrong, R.A., Rabarimanana, M.H., Ralison, A.V., 2011. A new geological framework for south-central Madagascar, and its relevance to the "out-of-Africa" hypothesis. Precambrian Res. 185, 109-130. https://doi.org/10.1016/j.precamres.2010.12.008

Tung, K., Yang, H.-J., Yang, H.-Y., Liu, D., Zhang, J., Wan, Y., Tseng, C.-Y., 2007. SHRIMP U-Pb geochronology of the zircons from the Precambrian basement of the Qilian Block and its geological significances. Chin. Sci. Bull. 52, 2687-2701. https://doi.org/10.1007/s11434-0070356-0

Vaes, B., Van Hinsbergen, D.J.J., Boschman, L.M., 2019. Reconstruction of subduction and back-arc spreading in the NW Pacific and Aleutian Basin: Clues to causes of Cretaceous and Eocene plate reorganizations. Tectonics 38, 1367-1413.

van der Meer, D.G., Spakman, W., van Hinsbergen, D.J.J., Amaru, M.L., Torsvik, T.H., 2010. Towards absolute plate motions constrained by lower-mantle slab remnants. Nat. Geosci. 3, 36-40. https://doi.org/10.1038/ngeo708

Van der Voo, R., 1990. The reliability of paleomagnetic data. Tectonophysics 184, 1-9. https://doi.org/10.1016/0040-1951(90)90116-P

Van der Voo, R., French, R.B., Williams, D.W., 1976. Paleomagnetism of the Wilberns Formation (Texas) and the late Cambrian paleomagnetic field for North America. J. Geophys. Res. 81, $5633-5638$.

van Hinsbergen, D.J.J., Lippert, P.C., Dupont-Nivet, G., McQuarrie, N., Doubrovine, P.V., Spakman, W., Torsvik, T.H., 2012. Greater India Basin hypothesis and a two-stage Cenozoic collision between India and Asia. Proc. Natl. Acad. Sci. U. S. A. 109, 7659-7664. https://doi.org/10.1073/pnas.1117262109

van Hinsbergen, D.J.J., Torsvik, T.H., Schmid, S.M., Maţenco, L.C., Maffione, M., Vissers, R.L.M., Gürer, D., Spakman, W., 2020. Orogenic architecture of the Mediterranean region and kinematic reconstruction of its tectonic evolution since the Triassic. Gondwana Res. 81, 79-229. https://doi.org/10.1016/j.gr.2019.07.009

Van Lente, B., Ashwal, L.D., Pandit, M.K., Bowring, S.A., Torsvik, T.H., 2009. Neoproterozoic hydrothermally altered basaltic rocks from Rajasthan, northwest India: Implications for late Precambrian tectonic evolution of the Aravalli Craton. Precambrian Res. 170, 202-222. https://doi.org/10.1016/j.precamres.2009.01.007 
van Staal, C.R., Barr, S.M., Brendan Murphy, J., 2012. Provenance and tectonic evolution of Ganderia: Constraints on the evolution of the Iapetus and Rheic oceans. Geology 40, 987-990. https://doi.org/10.1130/G33302.1

Vernikovsky, V.A., Vernikovskaya, A.E., 2001. Central Taimyr accretionary belt (Arctic Asia): MesoNeoproterozoic tectonic evolution and Rodinia breakup. Precambrian Res. 110, 127-141. https://doi.org/10.1016/S0301-9268(01)00184-X

Vernikovsky, V.A., Vernikovskaya, A.E., Kotov, A.B., Sal'nikova, E.B., Kovach, V.P., 2003. Neoproterozoic accretionary and collisional events on the western margin of the Siberian craton: new geological and geochronological evidence from the Yenisey Ridge. Tectonophysics 375, 147-168. https://doi.org/10.1016/S0040-1951(03)00337-8

Vernikovsky, V.A., Vernikovskaya, A.E., Pease, V.L., Gee, D.G., 2004. Neoproterozoic Orogeny along the margins of Siberia. Geological Society, London, Memoirs 30, 233-248. https://doi.org/10.1144/GSL.MEM.2004.030.01.18

Veselovskiy, R.V., Arzamastsev, A.A., 2011. Evidence for the Mesozoic endogenous activity in the northeastern part of the Fennoscandian Shield. Dokl. Earth Sci. 438, 754-758. https://doi.org/10.1134/S1028334X11060377

Vick, H.K., Channell, J.E.T., Opdyke, N.D., 1987. Ordovician docking of the Carolina Slate Belt: Paleomagnetic data. Tectonics 6, 573-583. https://doi.org/10.1029/TC006i005p00573

Vizan, H., Carney, J.N., Turner, P., Ixer, R.A., Tomasso, M., Mullen, R.P., Clarke, P., 2003. Late Neoproterozoic to Early Palaeozoic palaeogeography of Avalonia: some palaeomagnetic constraints from Nuneaton, central England. Geol. Mag. 140, 685-705. https://doi.org/10.1017/S001675680300832X

von Raumer, J.F., Stampfli, G.M., 2008. The birth of the Rheic Ocean-Early Palaeozoic subsidence patterns and subsequent tectonic plate scenarios. Tectonophysics 461, 9-20.

Walderhaug, H.J., Torsvik, T.H., Eide, E.A., Sundvoll, B., Bingen, B., 1999. Geochronology and palaeomagnetism of the Hunnedalen dykes, SW Norway: implications for the Sveconorwegian apparent polar wander loop. Earth Planet. Sci. Lett. 169, 71-83. https://doi.org/10.1016/S0012821X(99)00066-7

Walderhaug, H.J., Torsvik, T.H., Halvorsen, E., 2007. The Egersund dykes (SW Norway): a robust Early Ediacaran (Vendian) palaeomagnetic pole from Baltica. Geophys. J. Int. 168, 935-948. https://doi.org/10.1111/j.1365-246X.2006.03265.x

Wang, C., Liu, L., Wang, Y.-H., He, S.-P., Li, R.-S., Li, M., Yang, W.-Q., Cao, Y.-T., Collins, A.S., Shi, C., Wu, Z.-N., 2015. Recognition and tectonic implications of an extensive Neoproterozoic volcano-sedimentary rift basin along the southwestern margin of the Tarim Craton, northwestern 
China. Precambrian Res. 257, 65-82. https://doi.org/10.1016/j.precamres.2014.11.022

Wang, C.-C., Jacobs, J., Elburg, M.A., Läufer, A., Thomas, R.J., Elvevold, S., 2020. Grenville-age continental arc magmatism and crustal evolution in central Dronning Maud Land (East Antarctica): Zircon geochronological and HfO isotopic evidence. Gondwana Res. https://doi.org/10.1016/j.gr.2019.12.004

Weil, A.B., Geissman, J.W., Ashby, J.M., 2006. A new paleomagnetic pole for the Neoproterozoic Uinta Mountain supergroup, Central Rocky Mountain States, USA. Precambrian Res. 147, 234-259. https://doi.org/10.1016/j.precamres.2006.01.017

Weil, A.B., Geissman, J.W., Van der Voo, R., 2004. Paleomagnetism of the Neoproterozoic Chuar Group, Grand Canyon Supergroup, Arizona: implications for Laurentia's Neoproterozoic APWP and Rodinia break-up. Precambrian Res. 129, 71-92.

Weil, A.B., Van der Voo, R., Mac Niocaill, C., Meert, J.G., 1998. The Proterozoic supercontinent Rodinia: paleomagnetically derived reconstructions for 1100 to 800 Ma. Earth Planet. Sci. Lett. 154, 13-24. https://doi.org/10.1016/S0012-821X(97)00127-1

Wen, B., Evans, D.A.D., Li, Y.-X., 2017. Neoproterozoic paleogeography of the Tarim Block: An extended or alternative "missing-link" model for Rodinia? Earth Planet. Sci. Lett. 458, 92-106. https://doi.org/10.1016/j.eps1.2016.10.030

Wen, B., Evans, D.A.D., Wang, C., Li, Y.-X., Jing, X., 2019. A positive test for the Greater Tarim Block at the heart of Rodinia: Mega-dextral suturing of supercontinent assembly: REPLY. Geology 47, e454-e454.

Wen, B., Evans, D.A.D., Wang, C., Li, Y.-X., Jing, X., 2018. A positive test for the Greater Tarim Block at the heart of Rodinia: Mega-dextral suturing of supercontinent assembly. Geology 46, 687-690. https://doi.org/10.1130/G40254.1

Wen, B., Li, Y.-X., Zhu, W., 2013. Paleomagnetism of the Neoproterozoic diamictites of the Qiaoenbrak formation in the Aksu area, NW China: Constraints on the paleogeographic position of the Tarim Block. Precambrian Res. 226, 75-90. https://doi.org/10.1016/j.precamres.2012.10.018

White, C.E., Barr, S.M., Hamilton, M.A., Murphy, J.B., 2020. Age and tectonic setting of Neoproterozoic granitoid rocks, Antigonish Highlands, Nova Scotia, Canada: Implications for Avalonia in the northern Appalachian orogen. Can. J. Earth Sci.

White, C.E., Barr, S.M., Miller, B.V., Hamilton, M.A., 2002. Granitoid plutons of the Brookville terrane, southern New Brunswick: petrology, age, and tectonic setting.

Wilhem, C., Windley, B.F., Stampfli, G.M., 2012. The Altaids of Central Asia: A tectonic and evolutionary innovative review. Earth-Sci. Rev. 113, 303-341. https://doi.org/10.1016/j.earscirev.2012.04.001 
Williams, G.E., Schmidt, P.W., 2015. Low paleolatitude for the late Cryogenian interglacial succession, South Australia: paleomagnetism of the Angepena Formation, Adelaide Geosyncline. Aust. J. Earth Sci. 62, 243-253. https://doi.org/10.1080/08120099.2015.1003967

Williams, S., Flament, N., Dietmar Müller, R., Butterworth, N., 2015. Absolute plate motions since 130 Ma constrained by subduction zone kinematics. Earth Planet. Sci. Lett. 418, 66-77. https://doi.org/10.1016/j.eps1.2015.02.026

Windley, B.F., Alexeiev, D., Xiao, W., Kröner, A., Badarch, G., 2007. Tectonic models for accretion of the Central Asian Orogenic Belt. J. Geol. Soc. London 164, 31-47. https://doi.org/10.1144/001676492006-022

Wingate, M.T.D., Giddings, J.W., 2000. Age and palaeomagnetism of the Mundine Well dyke swarm, Western Australia: implications for an Australia-Laurentia connection at $755 \mathrm{Ma}$. Precambrian Res. 100, 335-357. https://doi.org/10.1016/S0301-9268(99)00080-7

Wingate, M.T.D., Pisarevsky, S.A., De Waele, B., 2010. Paleomagnetism of the 765 Ma Luakela volcanics in Northwest Zambia and implications for Neoproterozoic positions of the Congo Craton. Am. J. Sci. 310, 1333-1344. https://doi.org/10.2475/10.2010.05

Wu, C., Zuza, A.V., Yin, A., Liu, C., Reith, R.C., Zhang, J., Liu, W., Zhou, Z., 2017. Geochronology and geochemistry of Neoproterozoic granitoids in the central Qilian Shan of northern Tibet: Reconstructing the amalgamation processes and tectonic history of Asia. Lithosphere 9, 609-636. https://doi.org/10.1130/L640.1

Wu, J., Suppe, J., Lu, R., Kanda, R., 2016. Philippine Sea and East Asian plate tectonics since $52 \mathrm{Ma}$ constrained by new subducted slab reconstruction methods. J. Geophys. Res. [Solid Earth] 121, $4670-4741$.

Wu, L., Murphy, J.B., Quesada, C., Li, Z.-X., Waldron, J.W.F., Williams, S., Pisarevsky, S., Collins, W.J., 2020. The amalgamation of Pangea: Paleomagnetic and geological observations revisited. GSA Bulletin. https://doi.org/10.1130/B35633.1

Xia, B., Zhang, L., Du, Z., Xu, B., 2017. Petrology and age of Precambrian Aksu blueschist, NW China. Precambrian Res. https://doi.org/10.1016/j.precamres.2017.12.041

Xiao, W., Windley, B.F., Allen, M.B., Han, C., 2013. Paleozoic multiple accretionary and collisional tectonics of the Chinese Tianshan orogenic collage. Gondwana Res. 23, 1316-1341. https://doi.org/10.1016/j.gr.2012.01.012

Xiao, W., Windley, B.F., Yong, Y., Yan, Z., Yuan, C., Liu, C., Li, J., 2009. Early Paleozoic to Devonian multiple-accretionary model for the Qilian Shan, NW China. J. Asian Earth Sci. 35, 323-333. https://doi.org/10.1016/j.jseaes.2008.10.001

Xiao, W.J., Mao, Q.G., Windley, B.F., Han, C.M., Qu, J.F., Zhang, J.E., Ao, S.J., Guo, Q.Q., Cleven, 
N.R., Lin, S.F., Shan, Y.H., Li, J.L., 2010. Paleozoic multiple accretionary and collisional processes of the Beishan orogenic collage. Am. J. Sci. 310, 1553-1594. https://doi.org/10.2475/10.2010.12

Xu, D., Xia, B., Bakun-Czubarow, N., Bachlinski, R., Li, P., Chen, G., Chen, T., 2008. Geochemistry and Sr-Nd isotope systematics of metabasites in the Tunchang area, Hainan Island, South China: implications for petrogenesis and tectonic setting. Mineral. Petrol. 92, 361-391. https://doi.org/10.1007/s00710-007-0198-0

Xu, D.-R., Xia, B., Li, P.-C., Chen, G.-H., Ma, C., Zhang, Y.-Q., 2007. Protolith natures and U-Pb sensitive high mass-resolution ion microprobe (SHRIMP) zircon ages of the metabasites in Hainan Island, South China: Implications for geodynamic evolution since the late Precambrian. Island Arc 16, 575-597.

Xu, X., Song, S., Su, L., Li, Z., Niu, Y., Allen, M.B., 2015. The 600-580Ma continental rift basalts in North Qilian Shan, northwest China: Links between the Qilian-Qaidam block and SE Australia, and the reconstruction of East Gondwana. Precambrian Res. 257, 47-64. https://doi.org/10.1016/j.precamres.2014.11.017

Xu, Y., Cawood, P.A., Du, Y., Zhong, Z., Hughes, N.C., 2014. Terminal suturing of Gondwana along the southern margin of South China Craton: Evidence from detrital zircon $\mathrm{U}-\mathrm{Pb}$ ages and $\mathrm{Hf}$ isotopes in Cambrian and Ordovician strata, Hainan Island. Tectonics 33, 2490-2504.

Yakubchuk, A., 2017. Evolution of the Central Asian Orogenic Supercollage since Late Neoproterozoic revised again. Gondwana Res. 47, 372-398. https://doi.org/10.1016/j.gr.2016.12.010

Yang, B., Collins, A.S., Blades, M.L., 2019. Middle-late Mesoproterozoic tectonic geography of the North Australia Craton: $\mathrm{U}-\mathrm{Pb}$ and $\mathrm{Hf}$ isotopes of detrital zircon grains in the Beetaloo Sub-basin, Northern .... Journal of the.

Yang, B., Collins, A.S., Cox, G.M., Jarrett, A.J.M., Denyszyn, S., Blades, M.L., Farkaš, J., Glorie, S., 2020. Using Mesoproterozoic sedimentary geochemistry to reconstruct basin tectonic geography and link organic carbon productivity to nutrient flux from a Northern Australian large igneous Province. Basin Res. 60, 175. https://doi.org/10.1111/bre.12450

Yang, J.S., Wu, C.L., Chen, S.Y., Shi, R.D., Zhang, J.X., Meng, F.C., Zuo, G.C., Wu, H.Q., Constantinovskaya, E., 2006. Neoproterozoic eclogitic metamorphic age of the Beishan eclogite of Gansu, China: evidence from SHRIMP U--Pb isotope dating. Geology in China 33, 317-325.

Yang, Z., Otofuji, Y.-I., Sun, Z., Huang, B., 2002. Magnetostratigraphic constraints on the Gondwanan origin of North China: Cambrian/Ordovician boundary results. Geophys. J. Int. 151, 1-10. https://doi.org/10.1046/j.1365-246X.2002.01656.x

Yang, Z., Sun, Z., Yang, T., Pei, J., 2004. A long connection (750-380 Ma) between South China and 
Australia: paleomagnetic constraints. Earth Planet. Sci. Lett. 220, 423-434. https://doi.org/10.1016/S0012-821X(04)00053-6

Yang, Z.-Y., Sun, Z.M., Ma, X.H., Huang, B.C., Dong, J.M., Zhou, Y.X., Zhu, H., 1996. Preliminary paleomagnetic results from the Lower Paleozoic of North China (Henan Province) and its implications. Chinese Science Bulletin (in Chinese) 42, 401.

Yin, A., Harrison, T.M., 2000. Geologic Evolution of the Himalayan-Tibetan Orogen. Annu. Rev. Earth Planet. Sci. 28, 211-280. https://doi.org/10.1146/annurev.earth.28.1.211

Young, A., Flament, N., Maloney, K., Williams, S., Matthews, K., Zahirovic, S., Müller, R.D., 2019. Global kinematics of tectonic plates and subduction zones since the late Paleozoic Era. Geoscience Frontiers 10, 989-1013. https://doi.org/10.1016/j.gsf.2018.05.011

Yuan, C., Sun, M., Yang, J., Zhou, H., Zhou, M.-F., 2004. Nb-depleted, continental rift-related Akaz metavolcanic rocks (West Kunlun): implication for the rifting of the Tarim Craton from Gondwana. Geological Society, London, Special Publications 226, 131-143. https://doi.org/10.1144/GSL.SP.2004.226.01.07

Zeng, Y.-C., Chen, Q., Xu, J.-F., Chen, J.-L., Huang, F., Yu, H.-X., Zhao, P.-P., 2018. Petrogenesis and geodynamic significance of Neoproterozoic ( $~ 925 \mathrm{Ma}$ ) high-Fe-Ti gabbros of the RenTso ophiolite, Lhasa Terrane, central Tibet. Precambrian Res. 314, 160-169. https://doi.org/10.1016/j.precamres.2018.06.005

Zhan, S., Chen, Y., Xu, B., Wang, B., Faure, M., 2007. Late Neoproterozoic paleomagnetic results from the Sugetbrak Formation of the Aksu area, Tarim basin (NW China) and their implications to paleogeographic reconstructions and the snowball Earth hypothesis. Precambrian Res. 154, 143158. https://doi.org/10.1016/j.precamres.2007.01.001

Zhang, C.-L., Li, H.-K., Santosh, M., Li, Z.-X., Zou, H.-B., Wang, H., Ye, H., 2012. Precambrian evolution and cratonization of the Tarim Block, NW China: Petrology, geochemistry, Nd-isotopes and $\mathrm{U}-\mathrm{Pb}$ zircon geochronology from Archaean gabbro-TTG-potassic granite suite and Paleoproterozoic metamorphic belt. J. Asian Earth Sci. 47, 5-20. https://doi.org/10.1016/j.jseaes.2011.05.018

Zhang, C.-L., Li, Z.-X., Li, X.-H., Ye, H.-M., 2009. Neoproterozoic mafic dyke swarms at the northern margin of the Tarim Block, NW China: Age, geochemistry, petrogenesis and tectonic implications. J. Asian Earth Sci. 35, 167-179. https://doi.org/10.1016/j.jseaes.2009.02.003

Zhang, C.-L., Zou, H.-B., Li, H.-K., Wang, H.-Y., 2013. Tectonic framework and evolution of the Tarim Block in NW China. Gondwana Res. 23, 1306-1315. https://doi.org/10.1016/j.gr.2012.05.009

Zhang, J., Mattinson, C.G., Meng, F., Wan, Y., Tung, K., 2008. Polyphase tectonothermal history recorded in granulitized gneisses from the north Qaidam HP/UHP metamorphic terrane, western 
China: Evidence from zircon U-Pb geochronology. Geol. Soc. Am. Bull. 120, 732-749.

Zhang, N., Zhong, S., Leng, W., Li, Z.X., 2010. A model for the evolution of the Earth's mantle structure since the Early Paleozoic. J. Geophys. Res.

Zhang, Q.R., Piper, J.D.A., 1997. Palaeomagnetic study of Neoproterozoic glacial rocks of the Yangzi Block: palaeolatitude and configuration of South China in the late Proterozoic Supercontinent. Precambrian Res. 85, 173-199. https://doi.org/10.1016/S0301-9268(97)00031-4

Zhang, S., Evans, D.A.D., Li, H., Wu, H., Jiang, G., Dong, J., Zhao, Q., Raub, T.D., Yang, T., 2013. Paleomagnetism of the late Cryogenian Nantuo Formation and paleogeographic implications for the South China Block. J. Asian Earth Sci. 72, 164-177. https://doi.org/10.1016/j.jseaes.2012.11.022

Zhang, S., Li, H., Jiang, G., Evans, D.A.D., Dong, J., Wu, H., Yang, T., Liu, P., Xiao, Q., 2015. New paleomagnetic results from the Ediacaran Doushantuo Formation in South China and their paleogeographic implications. Precambrian Res. 259, 130-142. https://doi.org/10.1016/j.precamres.2014.09.018

Zhang, S.-H., Zhao, Y., Li, X.-H., Ernst, R.E., Yang, Z.-Y., 2017. The 1.33-1.30 Ga Yanliao large igneous province in the North China Craton: Implications for reconstruction of the Nuna (Columbia) supercontinent, and specifically with the North Australian Craton. Earth Planet. Sci. Lett. 465, 112-125.

Zhao, G., Cawood, P.A., Wilde, S.A., Sun, M., 2002. Review of global 2.1-1.8 Ga orogens: implications for a pre-Rodinia supercontinent. Earth-Sci. Rev. 59, 125-162. https://doi.org/10.1016/S00128252(02)00073-9

Zhao, G., Wang, Y., Huang, B., Dong, Y., Li, S., Zhang, G., Yu, S., 2018. Geological reconstructions of the East Asian blocks: From the breakup of Rodinia to the assembly of Pangea. Earth-Sci. Rev. 186, 262-286. https://doi.org/10.1016/j.earscirev.2018.10.003

Zhao, P., Chen, Y., Zhan, S., Xu, B., Faure, M., 2014. The Apparent Polar Wander Path of the Tarim block (NW China) since the Neoproterozoic and its implications for a long-term Tarim-Australia connection. Precambrian Res. 242, 39-57. https://doi.org/10.1016/j.precamres.2013.12.009

Zhao, X., Coe, R.S., Liu, C., Zhou, Y., 1992. New Cambrian and Ordovician paleomagnetic poles for the North China Block and their paleogeographic implications. J. Geophys. Res., Studi. Geol. 97, 1767-1788. https://doi.org/10.1029/91JB02742

Zhong, S., Liu, X., 2016. The long-wavelength mantle structure and dynamics and implications for largescale tectonics and volcanism in the Phanerozoic. Gondwana Res. 29, 83-104. https://doi.org/10.1016/j.gr.2015.07.007

Zhong, S., Rudolph, M.L., 2015. On the temporal evolution of long-wavelength mantle structure of the 
3244 Earth since the early Paleozoic. Geochem. Geophys. Geosyst. 16, 1599-1615.

3245 Zhong, S., Zhang, N., Li, Z.-X., Roberts, J.H., 2007. Supercontinent cycles, true polar wander, and very 3246 long-wavelength mantle convection. Earth Planet. Sci. Lett. 261, 551-564.

3247 https://doi.org/10.1016/j.eps1.2007.07.049

3248 Zhu, D.-C., Zhao, Z.-D., Niu, Y., Dilek, Y., Hou, Z.-Q., Mo, X.-X., 2013. The origin and pre-Cenozoic

3249 evolution of the Tibetan Plateau. Gondwana Res. 23, 1429-1454.

3250 https://doi.org/10.1016/j.gr.2012.02.002

3251 Zhu, D.-C., Zhao, Z.-D., Niu, Y., Dilek, Y., Mo, X.-X., 2011. Lhasa terrane in southern Tibet came from $3252 \quad$ Australia. Geology 39, 727-730. https://doi.org/10.1130/G31895.1

3253 Zhu, G.-Y., Ren, R., Chen, F.-R., Li, T.-T., Chen, Y.-Q., 2017. Neoproterozoic rift basins and their

3254 control on the development of hydrocarbon source rocks in the Tarim Basin, NW China. J. Asian

3255 Earth Sci. 150, 63-72. https://doi.org/10.1016/j.jseaes.2017.09.018 